UNIVERSIDADE DE SÃO PAULO

ANNA LUIZA DUARTE MAIELLO

\title{
ASPECTOS FUNDAMENTAIS DO NEGÓCIO JURÍDICO ASSOCIATIVO
}

São Paulo

2012 


\section{UNIVERSIDADE DE SÃO PAULO}

ANNA LUIZA DUARTE MAIELLO

\section{ASPECTOS FUNDAMENTAIS DO NEGÓCIO JURÍDICO ASSOCIATIVO}

Tese apresentada à Faculdade de Direito da Universidade de São Paulo para obtenção do título de Doutora em Direito.

Área de Concentração: Direito Civil

Orientador: Professor Titular Fernando Campos Scaff

São Paulo

2012 
Nome: DUARTE MAIELLO, Anna Luiza

Título: Aspectos Fundamentais do Negócio Jurídico Associativo

Tese apresentada à Faculdade de Direito da Universidade de São Paulo para obtenção do título de Doutora.

Aprovado em:

Banca Examinadora:

Prof. Dr. Instituição:

Julgamento: Assinatura:

Prof. Dr. Instituição:

Julgamento: Assinatura:

Prof. Dr. Instituição:

Julgamento: Assinatura:

Prof. Dr. Instituição:

Julgamento: Assinatura:

Prof. Dr. Instituição:

Julgamento: Assinatura: 


\section{RESUMO}

O presente trabalho tem por objetivo analisar os aspectos fundamentais do negócio jurídico associativo, na forma disciplinada pelo atual código civil. O legislador ampliou a disciplina referente à associação, pessoa jurídica de direito privado; definiu essa entidade e estabeleceu os elementos essenciais que seu estatuto deve conter. Inseriu regras acerca dos direitos dos membros e da transmissão da qualidade de associado. Tratou da sua exclusão e da necessidade da existência de uma justa causa para tanto. Foram elencadas normas acerca da convocação e competência da assembleia geral dos associados. Por fim, se estabeleceu regras acerca da dissolução dos entes e do destino do patrimônio remanescente, bem como da possibilidade de restituição da contribuição aos membros. Foi identificada omissão do legislador em relação a certos pontos, que serão estudados na presente tese de doutoramento, com auxílio de doutrina estrangeira, em especial a italiana. Para tanto, trataremos das principais características das associações, que as distinguem de outras pessoas jurídicas de direito privado, em especial as fundações e sociedades, analisando os seus elementos essenciais. Serão abordadas as formalidades previstas para sua constituição e aquisição da personalidade jurídica, bem como os efeitos da personificação. Será feita uma diferenciação entre as associações personificadas e não personificadas, para analisarmos se o regime jurídico aplicável a elas deveria ser distinto. Ademais, dentro da disciplina do negócio jurídico e do contrato, em especial, procuraremos identificar a natureza do ato constitutivo que dá origem à associação. A organização interna dessas entidades será estudada, envolvendo questões acerca da constituição, funcionamento, funções e competências dos seus órgãos, bem como a forma de tomada de deliberações e a disciplina de sua anulação, além dos problemas de conflitos de interesses e de responsabilidade dos administradores. Trataremos, ainda, das condições para alteração dos estatutos e das regras para retirada e exclusão dos membros e seus efeitos. Por fim, abordaremos a dissolução das associações.

Palavras-chave: associações, negócio jurídico associativo, associado, pessoas jurídicas de direito privado. 


\begin{abstract}
The present work aims to analyze the basic aspects of the legal transaction with the purpose of creating an association, as regulated by the current civil code. The legislator broadened the discipline referring to the association, a legal entity of private law. He defined this entity and set the essential elements that its bylaws must contain. $\mathrm{He}$ inserted rules concerning the rights of the members and the transmission of the quality of associate. He dealt with their exclusion and the necessity of the existence of a fair cause for it. Norms concerning the call and the competence of a general meeting of the associates have been foreseen. Finally, rules concerning the dissolution of the entities and the destination of the remaining assets have been established, as well as the possibility of the restitution of the contributions to the members. However, the legislator omitted some points, that will be studied in the present thesis with reliance on foreign doctrine, in particular the Italian one. In order to achieve that, we will deal with the main characteristics that distinguish the associations from other legal entities of private law, in special foundations and business entities such as partnerships and corporations. The formalities foreseen for its constitution and the acquisition of the legal entity will be discussed, as well as its effects. Differences between the associations with and without legal entity will be established, to conclude wether their applicable legal regime needs to be special. Moreover, dealing with the disciplines of the legal transaction and of the contract, specially, we will try to identify the nature of the constituent act that originates the association. The internal organization of these entities will be studied, involving questions regarding the constitution, operations, functions and abilities of its bodies. Besides that, the form of deliberating and the process to invalidate them will be analyzed, as well as the problems of conflicts of interests and responsibility of the managers. We will then have mentioned the conditions for alteration of the bylaws, the appraisal rights and the exclusion of the members and its effects. Finally, we will approach the dissolution of the associations.
\end{abstract}

Keywords: associations, legal transaction, associate, legal entities. 


\section{RIASSUNTO}

Il presente lavoro ha per scopo analizzare le funzioni di base del negozio giuridico associativo, nella forma disciplinata dal codice civile odierno. Il legislatore ha esteso la disciplina che si riferisce all'associazione, entità legale di diritto privato. Ha creato una definizione di questa entità e ha stabilito gli elementi essenziali che il relativo statuto deve contenere. Ha inserito le regole che riguardano ai diritti dei membri ed alla trasmissione della qualità dell'associato. Si è occupato alla relativa esclusione e alla necessità dell'esistenza di una giusta causa per la procedura. Le norme che riguardano alla chiamata ed alle competenze dell'assemblea degli associati sono state previste. Per concludere, si stabilisse le regole riferenti alla dissoluzione degli esseri e alla destinazione del patrimonio risultante, così come della possibilità di restituzione del contributo ai membri. Tuttavia, il legislatore ha ancora silenziato rispetto a qualche punti, che saranno discussi in questa tesi con l'aiuto della dottrina straniera, soprattutto l'italiana. Per farlo, ci occuperemo delle caratteristiche principali delle associazioni, che le distinguono dalle altre persone giuridiche di diritto privato, soprattutto le fondazioni e le società, analizzando i rispettivi elementi essenziali. Le formalità previste per la relativa costituzione ed aquisizione dell'entità corporativa saranno apprezzate, così come l'effetto della personificazione. Una differenziazione fra le associazioni riconosciute o meno sarà fatta, per concludere se il regime legale applicabile dovrà essere distinto. Inoltre, all'interno delle discipline del negozio giuridico e del contratto, in speciale, cercheremo di identificare la natura dell'atto costituente che dà origine all'associazione. L'organizzazione interna di queste entità sarà studiata, incluso la costituzione, il funzionamento, le funzioni e le competenze degli organi, oltre alla forma di deliberare in assemblee e la disciplina del relativo annullamento, oltre ai problemi dei conflitti degli interessi e della responsabilità degli amministratori. Discuteremo dei termini per l'alterazione degli statuti e delle regole per recesso ed esclusione dei membri e l' apposito effetto. Infine, studieremo la dissoluzione delle associazioni.

Parole chiave: associazioni, negozio giuridico associativo, associati, persone giuridiche di diritto privato. 


\section{SUMÁRIO}

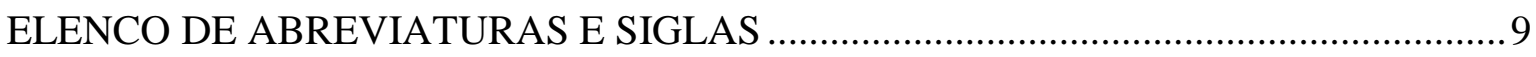

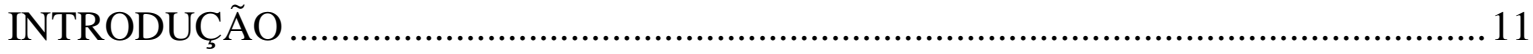

I - AS ASSOCIAÇÕES DE DIREITO PRIVADO .................................................. 17

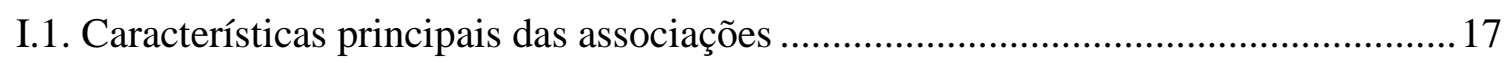

I.2. O elemento corporativo. Desnecessidade de patrimônio. Distinções entre associações

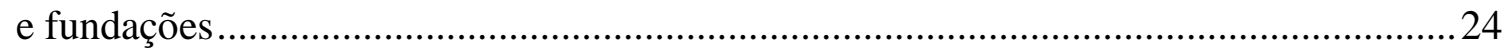

I.3. O fim das associações. A ausência de finalidade lucrativa. Distinção entre finalidade econômica e lucrativa. Possibilidade de exercício de atividade econômica. As

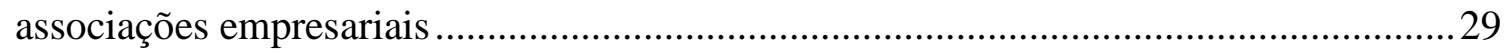

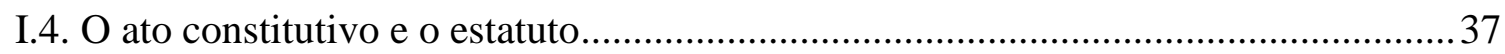

I.5. Os associados. Direitos e deveres. Igualdade e possibilidade de instituição de categorias diversas. Admissão. Existência de direito subjetivo à admissão. Transmissão da qualidade de associado. Inexistência de vínculos entre os associados ........................50

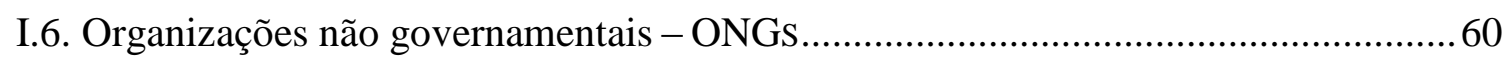

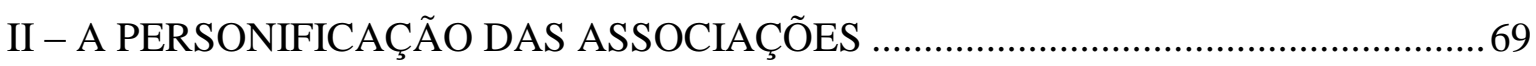

II.1. Constituição das associações e aquisição da personalidade jurídica........................69

II.2. Associações personificadas e não personificadas.................................................... 80

II.3. A associação como pessoa jurídica de direito privado ........................................... 95

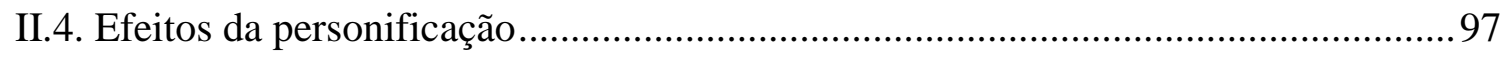

III - NATUREZA JURÍDICA DO ATO CONSTITUTIVO QUE DÁ ORIGEM ÀS

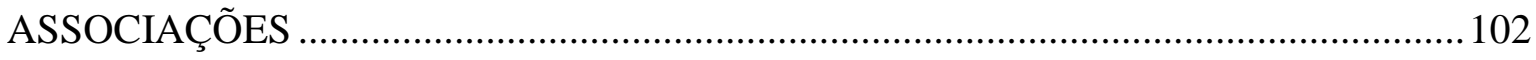

III.1. A associação como ato coletivo ou contrato plurilateral ........................................ 102

III.2. O contrato plurilateral aberto à adesão de novos associados. A cláusula de adesão.

Contratos com comunhão de escopo ....................................................................... 109

III.3. A associação brasileira como negócio jurídico que não é contrato .......................116

IV - ORGANIZAÇÃO INTERNA DAS ASSOCIAÇÕES ......................................... 130

IV.1. Órgãos da associação: constituição, eleição, funcionamento, funções e competência. Órgãos representativos e deliberativos. Órgãos necessários e facultativos.

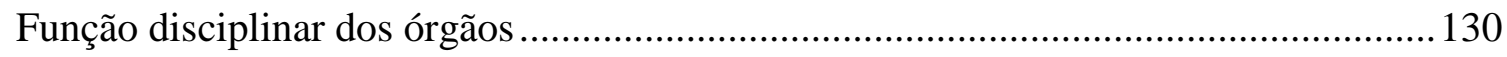

IV. 2. A Assembleia: competência, convocação, instalação e tomada de deliberações.

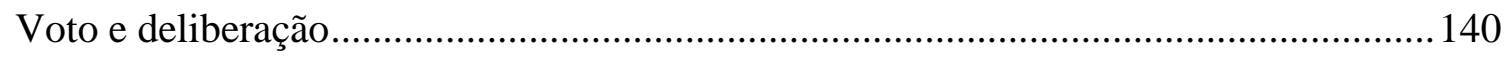

IV.3. Deliberações nulas e anuláveis. Legitimidade para a sua impugnação. Aplicação da

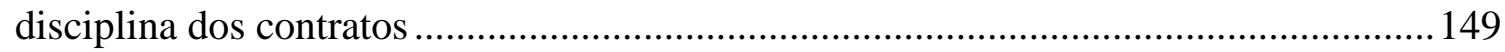


IV.4. Conflito de interesses 163

IV.5. Órgãos administrativos. A diretoria e o conselho de administração ou supervisão. Composição, competência, funções, eleição e destituição. Tomada e impugnação de deliberações 165

IV.6. Responsabilidade dos administradores em face da associação, dos associados, dos credores e de terceiros 172

IV.7. Órgãos de controle e de resolução de controvérsias internas 177

IV.8. Condições para alterações do estatuto 178

IV.9. Direito de retirada dos associados. 182

IV.10. Exclusão dos membros. A justa causa. Procedimento e defesa do associado. Efeitos da exclusão. 186

V - EXTINÇÃO DAS ASSOCIAÇÕES ......................................................................... 196

V.1. Dissolução, liquidação e extinção da associação ...................................................196

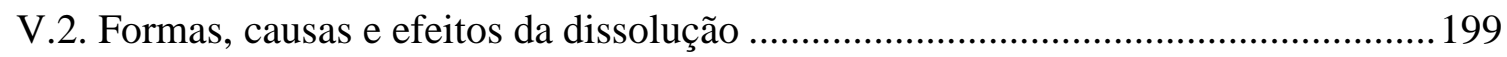

V.3. Proibição aos administradores de efetuar novas operações ..................................209

V.4. Destinação do patrimônio remanescente. Restituição das contribuições aos associados.

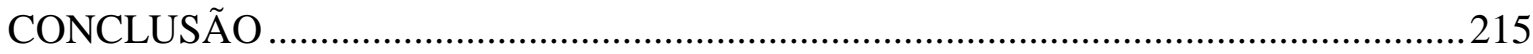

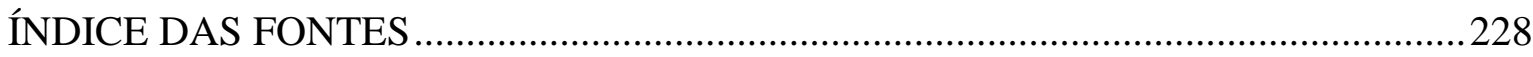

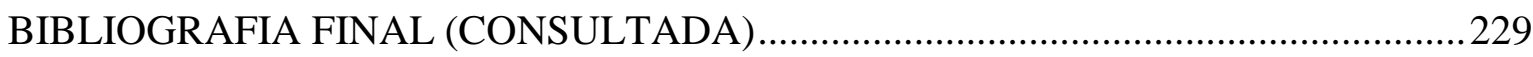




\section{ELENCO DE ABREVIATURAS E SIGLAS}

Entes ou instituições:

Ag. - Agravo

Apel. - Apelação

Câm. Dir. Priv.- Câmara de Direito Privado

CF - Constituição Federal

j. - julgado em

MP - Ministério Público

ONG - Organização não governamental

OS - Organização Social

OSCIP - Organização da Sociedade Civil de Interesse Público

RE - Recurso Extraordinário

rel. - relator

REsp - Recurso Especial

STF - Supremo Tribunal Federal

TJ - Tribunal de Justiça

UE - União Européia

Fontes:

BGB - Código Civil alemão (Bürgerlichen Gesetzbuch)

C.C. - Código Civil

C. Com. - Código Comercial

Lei das S.A. - Lei das Sociedades Anônimas 
Revistas, coleções e coletâneas:

RDM - Revista de Direito Mercantil

RT - Revista dos Tribunais 


\section{INTRODUÇÃO}

A presente tese de doutoramento tem por objeto a análise do negócio jurídico associativo, na forma disciplinada pelo atual Código Civil.

No Código Civil de 1916 as associações integravam as pessoas jurídicas de direito privado, ao lado das sociedades civis, religiosas, pias, morais, científicas ou literárias, fundações, sociedades mercantis e partidos políticos ${ }^{1}$.

Aquele diploma legal, contudo, pouco dizia dessas entidades ${ }^{2}$, tendo o Código Civil atual ampliado a sua disciplina, contendo regras importantes, que merecem um estudo aprofundado.

No Código Civil em vigor as associações são tidas como pessoas jurídicas de direito privado, juntamente com as sociedades, as fundações, as organizações religiosas e os partidos políticos ${ }^{3}$.

O legislador do Código Civil de 2002 definiu a associação e estabeleceu os elementos essenciais que o seu estatuto deve conter, sob pena de nulidade. Inseriu regras acerca dos direitos dos membros e da transmissão da qualidade de associado. Tratou da sua exclusão e da necessidade da existência de uma justa causa para tanto, garantindo o exercício do direito de defesa.

Foram previstas normas acerca da convocação e competência da assembleia geral dos associados. Por fim, se estabeleceu regras acerca da dissolução das entidades e do destino do patrimônio remanescente, bem como da possibilidade de restituição da contribuição aos associados.

Percebemos, portanto, que houve uma preocupação com a disciplina das associações, o que se pode considerar um avanço em relação à normativa anterior. Contudo, o legislador foi ainda omisso em relação a alguns pontos, que serão estudados com auxílio da doutrina estrangeira, em especial a italiana.

Temos como objetivo tratar do negócio jurídico associativo, explicando inicialmente as suas principais características. Estudaremos ainda sua natureza jurídica.

\footnotetext{
${ }^{1}$ Ver artigo 16 do Código Civil de 1916.

${ }^{2}$ Existia, apenas, a ideia de que as associações têm existência distinta dos seus associados, bem como regras acerca do término a existência da pessoa jurídica e do destino dos bens em caso de omissão do estatuto social. Ver artigos 20 a 22 do Código Civil de 1916.

${ }^{3}$ Ver artigo 44 do Código Civil.
} 
Para tanto, será analisada a figura do contrato plurilateral associativo, visto como um contrato especial, com estrutura aberta, que possibilita a entrada e a saída de seus associados.

O tema terá como limitações a análise do negócio jurídico associativo na forma disciplinada pelo Código Civil atual, contemplando, exclusivamente, as associações de direito privado.

Além disso, será efetuado o estudo da organização interna desses entes, explicando o funcionamento de seus órgãos essenciais, e de como devem ser tratadas a retirada e a exclusão dos associados.

A dissolução das associações também será abordada, distinguindo-se entre as fases de extinção, dissolução e liquidação.

As incertezas acerca do tema escolhido não são poucas.

A Teoria das Pessoas Jurídicas é uma parte muito controversa do Direito Civil. Há diversos trabalhos da doutrina que visam tratar dos conceitos, requisitos, princípios e da teoria geral das pessoas jurídicas. Ainda existem muitas questões referentes à existência, natureza e justificação das pessoas jurídicas.

A associação era confundida com a sociedade civil sem fins lucrativos, figura não mais existente. Há dúvidas sobre a possibilidade de a entidade exercer finalidade econômica. No Brasil, a associação é um negócio jurídico típico, e não há conclusões acerca do tipo do ato constitutivo que lhe dá origem.

Existem associações personificadas e não personificadas no direito brasileiro, em razão de que é necessário analisar se deverão ser aplicados regimes jurídicos distintos a cada uma delas. Não há previsão no Código Civil brasileiro acerca das associações irregulares, como fez o legislador italiano.

A autonomia privada possui relevância no estudo em questão, havendo diversas regras que podem ser escolhidas pelos associados para reger a associação. Existem elementos que não são essenciais, mas podem ser previstos no ato constitutivo e no estatuto para facilitar a solução de questões que possam surgir, como a destinação do patrimônio remanescente em caso de dissolução.

Na parte da organização interna, o tema é rico. Os associados podem dispor regras acerca da tomada de deliberações, elencar hipóteses que se qualificam como justa 
causa para a exclusão dos associados e prever normas para a solução de conflitos de interesses.

As dificuldades com o tema são sentidas também na jurisprudência, que muitas vezes aplicava regras de sociedades civis para as associações, justificando-se a importância do estudo da natureza do negócio jurídico associativo e do enquadramento do regime jurídico ao negócio.

O estudo será dividido em cinco capítulos.

O primeiro deles conterá uma análise das principais características das associações, que as distinguem de outras pessoas jurídicas de direito privado, em especial as fundações e sociedades.

Trataremos do elemento corporativo, que aproxima associações de sociedades. Analisaremos a desnecessidade de um patrimônio para a sua constituição, o que as diferencia das fundações.

O fim das associações merece um exame cuidadoso, sendo necessário tratar a razão da ausência da finalidade lucrativa, distinguindo entre ela e a finalidade econômica, bem como analisando a possibilidade das entidades exercerem as últimas. Destacaremos as associações empresariais francesas, abordando os conflitos que enfrentam, uma vez que o estatuto associativo não se mostra adequado para o exercício dessas atividades, além dos problemas de financiamento encontrados.

Em seguida, analisaremos o ato constitutivo e o estatuto das associações, os elementos considerados essenciais a eles e seus efeitos.

Abordaremos as regras referentes à admissão dos associados e à existência ou não de um direito subjetivo à admissão, desde que preenchidos os requisitos previstos no ato constitutivo ou estatuto. Trataremos da relação jurídica de membridade, dos direitos e deveres dela decorrentes, do princípio da igualdade entre os membros, analisando se há alguma afronta a ele pela possibilidade de instituição de categorias diversas. Estudaremos, ainda, as regras acerca da transmissão da qualidade de associado.

No final do primeiro capítulo, faremos uma breve menção às organizações não governamentais (ONGs), que assumem a forma de associações sem fins lucrativos ou fundações, em razão do seu papel relevante na economia, em especial como complemento das atividades do Estado. 
Pretendemos, no segundo capítulo, tratar das formalidades previstas para a constituição das associações e aquisição da personalidade jurídica.

Trataremos das pessoas jurídicas, gênero do qual as associações são espécies, abordando seus principais elementos, características e os efeitos da personificação, evitando retomar as diversas teorias que procuram justificar a existência e a natureza delas, para restringir o presente estudo.

O artigo 54 do Código Civil estabelece o que o estatuto da associação deve conter, sob pena de nulidade. Portanto, a sanção pelo descumprimento da elaboração de estatuto sem a indicação da denominação, dos fins e da sede da associação; dos requisitos para a admissão, demissão e exclusão dos associados; dos direitos e deveres dos associados; das fontes de recursos para sua manutenção; do modo de constituição e de funcionamento dos órgãos deliberativos; das condições para a alteração das disposições estatutárias e para a dissolução; da forma de gestão administrativa e de aprovação das respectivas contas é a nulidade.

Analisaremos as associações personificadas e não personificadas, tratando dos efeitos da personificação, para concluir se devem ser aplicados a elas diferentes regimes jurídicos.

O artigo 45 do Código Civil estabelece que começa a existência das pessoas jurídicas de direito privado com a inscrição do ato constitutivo no respectivo registro, precedida, quando necessário, de autorização ou aprovação do Poder Executivo.

Contudo, parece que uma associação possa existir e produzir efeitos sem ter procedido à inscrição do seu ato constitutivo no registro, tanto que se admite a existência de associações não personificadas, como fez F. C. PONTES DE MiRANDA, para quem associação é uma organização (subtrato) ${ }^{4}$. Nesse sentido, chegaria-se à conclusão de que a personificação opera no plano da eficácia.

Dentro da disciplina do negócio jurídico e do contrato, em especial, a natureza do ato constitutivo que dá origem à associação merece um estudo aprofundado, e será objeto do terceiro capítulo.

A doutrina estrangeira é fonte de ampla discussão sobre o tema escolhido. A escola francesa não desenvolveu uma posição clara acerca do tipo de negócio jurídico que

\footnotetext{
${ }^{4}$ F. C. Pontes De Miranda, Tratado de Direito Privado, Parte Geral, Tomo I - Introdução. Pessoas Físicas e Jurídicas, $2^{\mathrm{a}}$ ed., Rio de Janeiro, Borsoi, 1954, pp. 333- 334.
} 
dá origem à associação, tratando da associação na forma que é conhecida. A doutrina alemã adotou a posição de que o negócio jurídico que dá origem à associação não é contratual, tratando-se de um ato complexo.

Já na Itália, F. MESSINEO defendeu, de início, que a origem das associações não era contratual, acompanhando a posição dos doutrinadores alemães. T. AsCARELLI ${ }^{5}$ defendeu a natureza contratual dessas entidades. F. MESSINEO mudou de opinião, adotando a origem contratual do negócio jurídico associativo, ideia que passou a representar o consenso dos italianos ${ }^{6}$.

Analisaremos a natureza jurídica do ato constitutivo que dá origem à associação, estudando as escolas francesa, alemã e italiana, para poder concluir se este é ou não contratual.

Nesse contexto, será considerada a figura do contrato plurilateral associativo, visto como um contrato especial, com estrutura aberta, que possibilita a entrada e a saída de seus associados.

Trataremos da cláusula de adesão, tida como elemento essencial do negócio jurídico associativo, que deve ser aberto para o ingresso de novos associados.

Portanto, devemos partir da categoria negócio jurídico, para depois, como sugeriu R. STZAJN, chegar ao quadro geral dos negócios associativos, a partir do qual se verifica a existência de diferença específica que os distinga de outros da mesma espécie ${ }^{7}$.

Do gênero negócio associativo chega-se às espécies associação e sociedade.

O próximo capítulo pretende tratar da organização interna das associações, que envolve assuntos diversos.

Estudaremos, assim, da constituição, funcionamento, funções e competências dos órgãos das associações, em especial daqueles fundamentais, que são a assembleia de associados e a diretoria.

O quorum para a tomada de deliberações na assembleia e o critério de eleição dos administradores deve ser disposto no estatuto, sob pena de nulidade.

\footnotetext{
${ }^{5}$ O Contrato Plurilateral, in Problemas das Sociedades Anônimas e Direito Comparado, São Paulo, Saraiva, 1945, pp. 290- 291.

${ }^{6}$ F. Galgano, Il Negozio Giuridico, 2a. ed., Milano, Guiffrè, 2002, p. 39.

${ }^{7}$ Associações e sociedades, São Paulo, Revista de Direito Mercantil, ano XLI, n. 128, out/dez 2002, pp. 17 26.
} 
Contudo, pouco é previsto acerca da sua convocação, tendo sido apenas assegurado a um quinto dos associados o direito de fazê-lo.

Analisaremos a tomada de deliberações e a disciplina de sua anulação, bem como o problema dos conflitos de interesses e de responsabilidade dos administradores.

Trataremos, ainda, das condições para alteração dos estatutos e das regras para retirada e exclusão dos membros e seus efeitos.

A exclusão do associado é possível, desde que haja justa causa, mas não há definição das hipóteses de justa causa para exclusão, e nem regras sobre este procedimento, sendo apenas disposto que deve ser efetuada de forma a assegurar o direito de defesa e de recurso, nos termos previstos no estatuto.

Por fim, é importante analisar a dissolução das associações, que contém regras específicas de destinação dos bens à entidade de fins não econômicos designada no estatuto, ou, omisso este, por deliberação dos associados, à instituição municipal, estadual ou federal, de fins idênticos ou semelhantes.

Faremos a necessária distinção entre as fases de dissolução, liquidação e extinção, abordando as formas, causas e efeitos da primeira. Trataremos da proibição aos administradores de efetuar novas operações, da destinação do patrimônio remanescente e da possibilidade de restituição das contribuições aos associados.

Integra a tese uma análise de jurisprudência e dos atos constitutivos e estatutos de associações brasileiras. 


\section{AS ASSOCIAÇÕES DE DIREITO PRIVADO}

Sumário: I.1. Características principais das associações. I.2. O elemento corporativo. Desnecessidade de patrimônio. Distinções entre associações e fundações. I.3. O fim das associações. A ausência de finalidade lucrativa. Distinção entre finalidade econômica e lucrativa. Possibilidade de exercício de atividade econômica. As associações empresariais. I.4. O ato constitutivo e o estatuto. I.5. Os associados. Direitos e deveres. Igualdade e possibilidade de instituição de categorias diversas. Admissão. Existência de direito subjetivo à admissão. Transmissão da qualidade de associado. Inexistência de vínculos entre os associados. I.6. As organizações não governamentais - ONGs.

\section{I.1. Características principais das associações}

O Código Civil classifica as associações como pessoas jurídicas de direito privado, juntamente com as sociedades, as fundações, as organizações religiosas e os partidos políticos ${ }^{8}$.

Cada uma das espécies citadas possui suas peculiaridades, que as distinguem das demais. Por outro lado, às vezes apresentam características comuns que as aproximam, como trataremos no decorrer desse primeiro capítulo ${ }^{9}{ }^{10}$.

Normalmente as classificações das pessoas jurídicas de direito privado são efetuadas de acordo com as suas finalidades estatutárias. Falava-se em pessoas jurídicas de utilidade pública ou particular, além de se dividir o fim das primeiras em altruístico, egoístico, ideal ou não econômico ${ }^{11} 1213$.

\footnotetext{
${ }^{8}$ Ver artigo 44 do Código Civil de 2002.

${ }^{9}$ Ver C. A. DA Mota Pinto, Teoria Geral de Direito Civil, Coimbra, Coimbra Ed., 1992, p. 293. O autor critica a classificação legal das pessoas colectivas: "A classificação tripartida - associações, fundações e sociedades - não tem na sua base um critério unitário. Com efeito, as associações e sociedades são modalidades de pessoas colectivas do tipo corporativo e, nessa qualidade, opõem-se às fundações. Noutra perspectiva, porém, as associações e fundações integram uma mesma categoria, oposta às sociedades, na medida em que estas visam fins econômicos lucrativos e aquelas não."

${ }^{10}$ F. U. Coelho, Curso de Direito Civil, vol. I, $2^{\mathrm{a}}$ ed., São Paulo, Saraiva, 2006, p. 238, explica que, tanto nas associações quanto nas sociedades, pessoas com objetivos comuns unem seus esforço para alcançá-los, sendo que nas primeiras, a pessoas se unem em torno de objetivos não econômicos.

${ }^{11}$ Ver C. A. DA Mota PINTO, Teoria Geral cit. (nota 9 supra), pp. 268 e ss. O autor explica que: "O critério desta subdivisão é o da finalidade estatutária das pessoas colectivas ora consideradas. De acordo com tal critério há que distinguir as pessoas colectivas de utilidade pública e as de utilidade particular." As
} 
De acordo com a sua composição e origem, as pessoas jurídicas de direito privado podem ser divididas em associações ou fundações e corporações ${ }^{14}$.

Em relação ao Código Civil anterior, a disciplina das associações mereceu maior atenção, tendo o legislador resolvido alguns problemas enfrentados pelos doutrinadores.

No Código Civil de 1916 as associações eram divididas em "associações de utilidade pública e particular"15 e integravam as pessoas jurídicas de direito privado, ao

associações, objeto do nosso estudo, situam-se na primeira espécie, que por sua vez sofre subclassificações. Prossegue o autor: "Pessoas colectivas de direito privado e utilidade pública são as que propõem um escopo de interesse público, ainda que, concorrentemente, se dirijam à satisfação dum interesse dos próprios associados ou do próprio fundador". Tal subclassificação ainda comporta diversas modalidades: pessoas colectivas jurídicas de fim desinteressado ou altruístico e pessoas colectivas de fim interessado ou egoístico. Nas pessoas colectivas de fim desinteressado ou altruístico "o interesse próprio que os associados ou o fundador querem satisfazer é um interesse de natureza altruística; o interesse em promover certos interesses de outras pessoas (os beneficiários). Os associados ou o fundador tomam a peito determinados interesses alheios. E trata-se de pessoas colectivas de utilidade pública, porque à comunidade social importa que tais interesses sejam satisfeitos. (...). A esta categoria pertencem todas as fundações - exceptuado porventura algum raríssimo caso - e ainda um grande número de associações, como sejam as e beneficência ou as humanitárias". Já as pessoas colectivas de fim interessado ou egoístico "serão sempre - pode dizer-se - de tipo corporativo, o escopo visado interessa de modo egoístico aos próprios associados, mas é tal que ao mesmo tempo interessa à comunidade." Como o fim pode ser de diversa ordem, existe uma última subdivisão da categoria de pessoas colectivas de direito privado de utilidade pública de fim interessado ou egoístico em pessoas colectivas de fim ideal e de fim econômico não lucrativo. Nas pessoas colectivas de fim ideal "o objetivo egoístico que uma pessoa colectiva se proponha pode consistir dum interesse de natureza ideal (não econômica): recreio, desporto, instrução, cultura física ou intelectual, etc.”. Já as pessoas colectivas de fim econômico não lucrativo são conceituadas da seguinte forma: "Aqui a pessoa colectiva pretende conseguir certas vantagens patrimoniais para os seus associados: subsídios pecuniários no caso de invalidez; empréstimos em boas condições, etc. Trata-se pois de uma finalidade econômica. Mas não de uma finalidade lucrativa, pois não se cuida propriamente de obter lucros para repartir pelos associados. Nesta categoria localizam-se, indubitavelmente, as associações de socorros mútuos e instituições congêneres, as caixas de crédito agrícola, os sindicatos, as associações patronais e, indiscutivelmente, as cooperativas de consumo, crédito construção e habitação."

${ }^{12}$ F. U. CoELHO, Curso de Direito Civil cit. (nota 10 supra), p. 249, explica que: "Algumas expressões são tradicionalmente empregadas na denominação da associação em função de seus fins. Assim, é comum chamá-la de instituto, quando tem natureza cultural; de clube, quando seus objetivos são esportivos, sociais ou de lazer; de academia de letras, quando reúne escritores; de centro acadêmico, quando congrega estudantes de determinado curso universitário."

${ }^{13}$ M. H. DINIZ, Curso de Direito Civil Brasileiro, $24^{a}$ ed., São Paulo, Saraiva, 2007, pp. 243-252, analisando os estatutos das associações e as atividades por elas exercidas, elaborou um rol exemplificativo delas. Nesse sentido, as associações podem ser pias, beneficentes ou filantrópicas; de assistência social; de utilidade pública; organizações religiosas, subdivididas em confrarias ou irmandades, fábricas paroquiais, ordens monásticas e cabidos; secretas com fins lícitos; estudantis; formadas para manutenção de escolas livres ou de extensão cultural; culturais; de profissionais liberais; desportivas; organizadoras de corridas de cavalos; recreativas ou sodalícias; de amigos do bairro ou de fomento e defesa; as caixas de socorro; os sindicatos ou organizações profissionais representativos de uma categoria profissional idêntica, similar ou conexa; para o exercício de atividade de garimpagem; cooperativas; formadas entre proprietários para execução e manutenção de trabalhos; de poupança e empréstimo; de agentes de seguro; convenção coletiva de consumo; trustes ou entes entre produtores; grupos formados entre usuários de um serviço público e partidos políticos.

${ }^{14}$ Ver L. DA C. GonçAlves, Direito Civil - Parte Geral, vol. I, São Paulo, Max Limonad, 1951, p. 107, que, após classificar as pessoas jurídicas de direito privado, define as associações como um "grupamento de indivíduos, que tomam a iniciativa de realizar um determinado fim, e neste intuito congregam atividades e constituem um patrimônio por contribuições de cada um". 
lado das sociedades civis, religiosas, pias, morais, científicas ou literárias, fundações, sociedades mercantis e partidos políticos ${ }^{16} 17$.

A categoria sociedade civil - abolida no novo Código - gerava muitas confusões com a associação em sentido estrito. A principal distinção entre ambas era que as primeiras não possuíam finalidade lucrativa, como as segundas ${ }^{18}$.

Contudo, algumas leis ainda se referem à nomenclatura anterior, em especial a Lei 6.015/73 (Lei dos Registros Públicos), que menciona, em seu artigo 114, as sociedades civis e associações de utilidade pública ${ }^{19}$.

Segundo W. MORAES as sociedades eram classificadas em civis ou mercantis, e dentre as civis existia a sociedade civil propriamente dita e em sentido restrito. Para a doutrina a sociedade civil estrita é constituída com finalidade econômica ou lucrativa, enquanto o outro tipo - a associação - possui finalidade ideal, não econômica. Ainda assim, a lei não distinguia entre sociedade de fim econômico e associação de fim ideal. Pelo Código Civil de 1916 sociedades civis eram as civis em sentido estrito e

${ }^{15}$ De acordo com W. MoraES, Sociedade Civil Estrita, São Paulo, RT, 1987, pp. 111-112, a Lei 91/35 regulou, para efeito de favores do Estado, a declaração de utilidade pública de sociedades civis, associações e fundações constituídas para "o fim exclusivo de servir desinteressadamente à coletividade". De acordo com essa disposição, só poderiam merecer declaração de utilidade púbica as instituições altruístas puras. Em seguida o decreto 50.517/61 esclareceu o requisito da exclusividade: deve tratar-se de entidade dedicada exclusivamente ao serviço desinteressado da coletividade.

${ }^{16}$ Ver artigo 16 do Código Civil de 1916.

${ }^{17}$ L. DA C. GonÇaLVES, Direito Civil cit. (nota 14 supra), p. 109, defendia que uma entidade poderia reunir as duas características: "Associações de utilidade pública e particular conjuntamente são aquelas que, promovendo e defendendo os interesses de uma classe social, simultaneamente favorecem a economia nacional; tais são os organismos corporativos: grêmios, sindicatos, Casas do Povo, Casas dos Pescadores, Casas de Lavoura, as Caixas de Crédito Agrícola, as associações de socorros mútuos, as cooperativas, etc."

${ }^{18}$ Ver C. Bevilaqua, Código Civil dos Estados Unidos do Brasil comentado por Clovis Bevilaqua, vol. I, $12^{\mathrm{a}}$ ed., Rio de Janeiro, Paulo Azevedo, 1959, p. 176, que conceituou as sociedades civis da seguinte forma: "Na acepção genérica de sociedade civil, compreendem-se várias modalidades de entes coletivos. Uns têm fins econômicos, e são sociedades civis em sentido restrito. Outros prosseguem fins ideais ou não econômicos: são as religiosas, pias, morais, científicas, literárias e de utilidade pública. As sociedades de fins não econômicos se costumam denominar associações; mas o Código não distingue entre sociedade e associação, como se vê deste artigo. É verdade que reservou o vocábulo associação para as agremiações de utilidade pública, e que designou a seção III deste capítulo - das sociedades e associações civis, mas, desde que se não forneceu, na lei, elemento para uma distinção dessa natureza, e desde que se tome em consideração que os estabelecimentos pios e as sociedades, que o Código denominou morais, são de utilidade pública, reconhecer-se-á que não houve intuito de criar duas classes de pessoas jurídicas: a sociedades civis, lato sensu, e as associações. O que se deve induzir da linguagem do Código é que é lícito, mas não obrigatório, denominar associações as sociedades de fins não econômicos." (Ver os arts. 20 a 23 e 1.363 a 1.409 do Código Civil de 1916).

19 “Art. 114. No Registro Civil de Pessoas Jurídicas serão inscritos:

I - os contratos, os atos constitutivos, o estatuto ou compromissos das sociedades civis, religiosas, pias, morais, científicas ou literárias, bem como o das fundações e das associações de utilidade pública;

II - as sociedades civis que revestirem as formas estabelecidas nas leis comerciais, salvo as anônimas.

III - os atos constitutivos e os estatutos dos partidos políticos." 
também as associações de fim ideal, regendo-se ambas pelas disposições do contrato de sociedade $^{20}$.

O Código Civil anterior continha uma disciplina sucinta acerca das associações, tendo o atual ampliado a sua regulação, contendo normas importantes, que merecem um estudo aprofundado ${ }^{21}$.

Antes da promulgação do Código Civil atual, a Constituição Federal houve por bem garantir, em seu artigo $5^{\circ}$, inciso XVII, a liberdade de associação para fins lícitos.

As principais características das associações, destacadas pela doutrina, são: a reunião de indivíduos que objetivam alcançar uma finalidade comum, não lucrativa, através de contribuições, que podem ser ou não pecuniárias e que constituem o patrimônio da entidade. Destaca-se, ainda, a liberdade que os membros possuem de criar os seus estatutos e de regular a organização da associação, além da proibição de distribuição de $\operatorname{lucros}^{22} 23$.

Os associados possuem liberdade para criar os estatutos, inserindo as disposições que entendem pertinentes, desde que não sejam contrárias à lei ${ }^{24}$. Deliberam livremente, podendo inclusive alterar a finalidade da entidade, desde que não haja intenção de dividir resultados 25 .

${ }^{20}$ Sociedade Civil Estrita cit. (nota 15 supra), São Paulo, RT, 1987, pp. 24-25.

${ }^{21}$ Existia, apenas, a ideia de que as associações têm existência distinta dos seus associados, bem como regras acerca do término a existência da pessoa jurídica e, nesse caso, do destino dos bens em caso de omissão do estatuto social, nos artigos 20 a 22 do Código Civil de 1916.

${ }^{22}$ Ver C. M. DA SILVA PEREIRA, Instituições de Direito Civil, vol. I, 12 a ed., Rio de Janeiro, Forense, 1991, p. 215, que define as pessoas jurídicas de direito privado, a exemplo das associações, como "entidades que se originam do poder criador da vontade individual, em conformidade com o direito positivo, e se propõe realizar objetivos de natureza particular para benefício dos próprios instituidores, ou projetadas no interesse de uma parcela determinada ou indeterminada da coletividade".

${ }^{23}$ C. M. DA SILVA PEREIRA, Instituições cit. (nota 22 supra), p. 230. A associação, de fins não lucrativos, é "aquela que se propõe realizar atividades não destinadas a proporcionar interesse econômico aos associados". Segundo o autor: "Com este critério, classificam-se ainda na categoria de associações ideais aquelas que realizam negócios visando ao alargamento patrimonial da pessoa jurídica, sem proporcionar ganhos aos associados. Assim é que não perdem esse caráter as associações recreativas que mantém um serviço de venda de refeições aos associados, ou cooperativas que fornecem aos seus membros víveres e utilidades, muito embora instituam margem de lucro a benefício da própria entidade."

${ }^{24}$ Nesse sentido, destacamos o entendimento de R. GENTIL, As Associações e suas Eleições, Tribuna do Direito, n. 139, nov. 2004, p. 12: "Com o cuidado de não contrariar a lei e respeitando-a nos seus Cânones e no contexto social que está inserida, há que se estar atento a que a parte volitiva continua reservada aos associados, cabendo a eles retratar, através do estatuto, o que considerarem necessário para conduzir as associações aos seus destinos."

${ }^{25}$ Ver M. H. DiNIZ, Curso de Direito Civil cit. (nota 13 supra), p. 239. 
Os direitos e obrigações se formam entre os associados e a associação, não havendo entre os membros direitos e obrigações recíprocos. Não existe, portanto, vínculo direto entre os associados ${ }^{26}$.

Os futuros membros da associação, através de declarações de vontade paralelas, convergindo para uma finalidade comum que almejam atingir, constituem a entidade, através de um negócio jurídico coletivo ${ }^{27}$.

É justamente este objetivo comum que une as pessoas, criando um vínculo, para buscar o fim que desejam alcançar, embora não crie direitos nem obrigações recíprocos entre eles ${ }^{28}$.

Com relação à legitimidade, é reconhecida à associação civil regularmente constituída a capacidade de propor ações coletivas, como a ação civil pública, para tutelar os direitos individuais homogêneos de seus associados ${ }^{29}$. É permitida a substituição processual nesses casos. Tem-se admitido a propositura da ação sem a necessidade de prévia autorização da assembleia de associados ${ }^{30}$.

O nosso estudo será limitado às associações de direito privado. Não trataremos das denominadas associações públicas, que são pessoas jurídicas de direito público interno criadas para dar suporte ao consórcio a ser firmado entre os entes públicos $^{3132}$.

Desde 1901 o legislador francês definiu a associação como a convenção pela qual duas ou mais pessoas colocam em comum de modo permanente seus

\footnotetext{
${ }^{26}$ Ver artigo 53 caput e parágrafo único do Código Civil de 2002.

${ }^{27}$ F. AMARAL, Direito Civil - Introdução, 6a ed., Rio de Janeiro, Renovar, 2006, p. 289.

${ }^{28}$ R. DE RUGGIERO, Instituições de Direito Civil, vol. I, $3^{\mathrm{a}}$ ed., trad. por ARY DOS SANTOS e revista e adaptada por Antônio Chaves e Fábio Maria de Mattia, São Paulo, Saraiva, 1971, p. 389 explica, sobre o vínculo que une os associados: "O vínculo, que une os associados e torna unitária a organização, depende da causa que leva as pessoas a associarem-se e do fim que, ao associar-se, se propuseram atingir. A reunião pode ter sido querida livremente, - e é o que geralmente sucede - para fins lucrativos, humanitários, científicos etc; e pode ser coativamente imposta pela lei quando, para conseguir fins que ultrapassam as forças individuais e têm um interesse social prevalecente sobre o interesse pessoal dos indivíduos, seja imposta a determinadas pessoas, mediante dados requisitos (como, por exemplo, a posse dos bens imobiliários, a gestão de uma indústria), a sua cooperação na forma corporativa (por ex., nos consórcios). O vínculo surge assim, qualquer que tenha sido a causa da associação, do ato de constituição, que tal como liga os que primeiramente a fundaram, igualmente liga todos os novos membros, aos quais o pacto é extensivo por aceitação tácita.(...)"

${ }^{29}$ TJRS, $9^{a}$ Câm. Cível, Ag. nos. 70019284116, 70019317080, 70019352186, rel. Odone Sanguiné, j. 25-62007; STJ, $3^{\mathrm{a}}$ Turma, R.Esp. n. SP 313.364-SP, rel. Min. Ari Pargendler, j. 27-11-2001; STJ, $4^{\mathrm{a}}$ Turma, REsp. 173379-SP, rel. Min. César Asfor Rocha, j. 14-12-2001.

${ }^{30}$ STJ, $4^{\mathrm{a}}$ Turma, REsp. 1189273-SC, rel. Min. Luís Felipe Salomão, j. 1-3-2011.

${ }^{31}$ Ver o inciso IV do art. 44 da Lei 11.107/05.

${ }^{32}$ Ver a respeito J. E. S. PAES, Fundações, Associações e Entidades de Interesse Social, $7^{\mathrm{a}}$ ed., Rio de Janeiro, Forense, 2010, p. 59.
} 
conhecimentos ou a sua atividade com algum objetivo diverso da distribuição dos benefícios. A associação deve ser regida, quanto à sua validade, pelos princípios gerais de direito aplicáveis aos contratos e obrigações, uma vez que o fundamento da associação é tido como contratual ${ }^{33}$.

Para aquele ordenamento, assim como para o brasileiro, é proibida a distribuição dos lucros entre os associados, não possuindo a associação finalidade lucrativa. O contrato de associação é uma convenção regida pelo direito das obrigações, havendo liberdade de contratar e de escolher o conteúdo do contrato. Sendo uma convenção, o contrato de associação supõe o consentimento dos membros fundadores, que ocorre normalmente em uma assembleia geral de constituição ${ }^{34}$.

As principais características do contrato de associação no direito francês são a existência, por parte dos fundadores e de todos os membros, de uma contribuição de conhecimento ou de atividade. A associação é desprovida de capital social, sendo a contrapartida ao aporte de conhecimento ou atividade a atribuição da qualidade de associado. Conjuntamente, os membros fundadores podem realizar um aporte em números ou em natureza, transferindo à associação a propriedade, o usufruto ou o uso de bens imóveis. O aporte de conhecimento ou de uma atividade deve ser feito de forma permanente. A associação não é uma simples reunião momentânea, mas pode ter prazo de duração determinado ${ }^{35}$.

O escopo é o objetivo que os fundadores se propõem a atender. Pode ser de caridade, humanitário, científico, cultural, esportivo, e outros. Independente do escopo escolhido, a associação não pode distribuir os lucros, embora possa exercer atividade lucrativa. A associação é regida, quanto à sua validade, pelos princípios gerais de direito aplicáveis aos contratos e às obrigações ${ }^{36}$.

Na França, existem os seguintes tipos de associações: associação de fato, que é um grupamento de pessoas que não efetuaram nenhuma declaração de existência, não possuindo patrimônio nem capacidade de direito; declarada, que é a forma mais comum, que segue as formalidades legais, possuindo capacidade jurídica; e de utilidade

\footnotetext{
${ }^{33}$ Ver a Lei de 1.07.1901, relativa ao contrato de associação.

${ }^{34}$ Ver S. DAmarey et al, Code des Associations et Fondations Commenté, $1^{\mathrm{a}}$ ed., Paris, Dalloz, 2008, pp. 7-8.

${ }^{35}$ S. DAMAREY et al, Code cit. (nota 34 supra), p. 8.

${ }^{36}$ S. DAMAREY et al, Code cit. (nota 34 supra), pp. 8-9.
} 
pública reconhecida, quando a autoridade competente admitir a importância e o papel de utilidade pública da associação, que deverá respeitar determinadas obrigações ${ }^{37}$.

A doutrina francesa define as associações como grupamentos de pessoas sem fins lucrativos, que são vistas como um contrato. Os seus membros colocam em comum, de forma permanente, os seus conhecimentos ou atividades em prol de um fim que não seja divisão de lucros. Ressalta-se que não existe proibição para produzir lucros, mas sim para dividi-los entre os associados ${ }^{38}$.

$\mathrm{Na}$ Argentina, as associações são classificadas em associações civis, mutualidades, fundações, associações de fomento, associações profissionais de trabalhadores, academias nacionais e associações religiosas ${ }^{39}$.

O patrimônio inicial das associações na Argentina é representado pelos bens aportados e deverá possibilitar o cumprimento dos fins sociais em medida razoável. Essas entidades não possuem finalidade lucrativa e são inspiradas na solidariedade humana, constituindo-se livremente com o propósito de ajuda recíproca de seus membros, que mediante uma contribuição periódica adquirem os direitos reconhecidos pelos estatutos ${ }^{40}$.

Concluímos, assim, que as associações de direito privado reúnem um conjunto de associados, que a ela aderem livremente, para buscar interesses de natureza não econômica. Contribuem com a prestação de serviços, com determinado conhecimento ou com a agregação de patrimônio para buscar o objetivo comum, que não possui finalidade lucrativa, havendo autonomia para regular as atividades e a organização, em busca dos interesses perseguidos, desde que a regulação escolhida não seja contrária à lei. A associação pode exercer atividade econômica, mas não pode haver distribuição dos resultados entre seus membros, devendo o eventual proveito econômico obtido ser utilizado para o alcance do escopo comum. Pode ser inclusive constituída sem patrimônio, como explicaremos a seguir.

\footnotetext{
${ }^{37}$ P. DelamarRe, Créer e faire vivre son association, Paris, Dalloz, 2004, pp. 16-18.

${ }^{38}$ Ver B. TeYssiÉ, Droit Civil - Les Personnes,4 ${ }^{a}$ ed., Paris, Litec, 1999, pp. 313-318.

${ }^{39}$ Ver M. Danielian e J. I. B. Peret, Personas Juridicas, La Plata, Editorial Fides, 1973, pp. 457-458.

${ }^{40}$ M. Danielian e J. I. B. Peret, Personas Juridicas cit. (nota 39 supra), pp. 457-488.
} 
I.2. O elemento corporativo. Desnecessidade de patrimônio. Distinções entre associações e fundações

Como mencionamos no item anterior, as principais características das associações destacadas pela doutrina são que se tratam de uniões de pessoas que se organizam para fins não econômicos. O fator de destaque é a reunião dos esforços dos associados, para buscar um objetivo comum.

Nesse sentido, o elemento preponderante é o seu aspecto eminentemente pessoal, enquanto nas fundações o aspecto dominante é o material. As associações em sentido estrito não necessitam, em princípio, de patrimônio para se constituir, embora, posteriormente, sejam necessários bens para a sua manutenção ${ }^{41}$.

A doutrina reúne as espécies associações e sociedades no conceito de corporação, para distingui-las das fundações ${ }^{42} 43$.

C. M. DA Silva PereIRA explica que as associações podem ter ou deixar de ter patrimônio, o que seria uma conquista do direito moderno, a admissão da existência de uma pessoa jurídica desprovida de bens ${ }^{44} 4546$.

O elemento pessoal predomina nas associações, sendo o patrimônio um elemento secundário ${ }^{47}$.

\footnotetext{
${ }^{41}$ Ver F. AMARAL, Direito Civil cit. (nota 27 supra), pp. 289-297.

${ }^{42}$ W. De Barros Monteiro, Curso de Direito Civil - Parte Geral, 42a ed, São Paulo, Saraiva, 2009, p. 150.

${ }^{43}$ Ver também C. A. DA MOTA PINTO, Teoria Geral cit. (nota 9 supra), p. 267, narrando que existem duas espécies fundamentais de pessoas coletivas: as corporações nas quais se incluem as associações, e as fundações: "Há com efeito duas espécies fundamentais de pessoas coletivas: as corporações e as fundações. As corporações têm um substrato integrado por um agrupamento de pessoas singulares que visam um interesse comum, egoístico ou altruístico. Essas pessoas ou associados organizam a corporação, dão-lhe existência e cabe-lhes disciplinar sua vida e destino. Dirigem-na de dentro, tendo nas suas mãos, através da modificação de seus estatutos ou de outras deliberações, a sorte da corporação. São corporações as associações desportivas, culturais, recreativas, mutualistas, as sociedades comerciais, etc."

${ }^{44}$ C. M. DA SILVA PEREIRA, Instituições cit. (nota 22 supra), p. 215.

45 No mesmo sentido, ver C. A. DA MotA PINTO, Teoria Geral cit. (nota 9 supra), p. 271: "Pode existir a corporação, sem que lhe pertença um patrimônio; basta pensar numa associação para a qual os associados concorrem apenas com serviços dirigidos a prossecução do fim comum (p. ex., fins de assistência moral), sem que os referidos serviços sejam susceptíveis de avaliação pecuniária. Por outro lado, mesmo quando o patrimônio exista, é a colectividade dos sócios dominando a vida da corporação, com a sua vontade, quem ocupa o primeiro plano."

${ }^{46}$ Ver, ainda, W. DE BARros MonTeIRo, Curso de Direito Civil cit. (nota 42 supra), pp. 152 e ss., esclarecendo que a constituição das associações depende do concurso de dois elementos, o formal e $o$ material. O primeiro deles compreende os atos da associação; o fim a que se propõe a pessoa jurídica e o conjunto de bens necessários à consecução desse fim. Já o elemento material é o patrimônio necessário à consecução do objetivo social, que não precisa existir no momento da constituição da associação, podendo ser formado posteriormente, com a contribuição futura dos associados.
} 
Portanto, tanto os elementos pessoais quanto os patrimoniais estão presentes nas associações e nas fundações, mas a importância de cada um deles varia em cada espécie $^{48}$.

Assim, a associação é vista como uma coletividade de pessoas, enquanto a fundação é um agrupamento de bens ${ }^{49} 50$.

A referida classificação das pessoas jurídicas em corporações ou fundações - denominadas também instituições - tem como critério a sua estrutura interna. As corporações são grupos de pessoas, administradas por seus próprios membros, que através de suas contribuições constituem o patrimônio comum de sua livre disposição ${ }^{51}$.

Nas associações, os interesses perseguidos são aqueles escolhidos pelos associados, que podem inclusive alterá-los. Já nas fundações os fins almejados são os eleitos pelo fundador, que são perenes e imutáveis ${ }^{52}$.

Como os associados deliberam livremente nas associações, os seus órgãos são denominados dirigentes ou dominantes, em oposição às fundações, cujos órgãos são ditos servientes, pois as resoluções são delimitadas pelo instituidor ${ }^{53}$.

No direito italiano, existe uma pluralidade de modelos associativos, destacando-se as associações e as fundações, que foram reguladas pelo legislador de forma unitária, em razão da sua qualificação comum de pessoas jurídicas. Ambas classificam-se como entes ou fenômenos coletivos, por serem formadas por sujeitos que colaboram para a realização de interesses de várias pessoas ${ }^{54}$.

\footnotetext{
${ }^{47}$ Ver S. T. DANTAS, Programa de Direito Civil-Parte Geral, $4^{\text {a }}$ tiragem, Rio de Janeiro, Ed. Rio, 1979, p. 215.

${ }^{48}$ Ver J. E. S. PAES, Fundações, Associações e Entidades cit. (nota 32 supra), p. 72.

${ }^{49}$ Ver L. FrançA, Instituições de Direito Civil, $3^{\mathrm{a}}$ ed. São Paulo: Saraiva, 1994, p. 71, explicando que a ideia vem dos romanos, da distinção entre universitas personarum e universitas bonorum.

${ }^{50}$ S. Rodrigues, Direito Civil - Parte Geral, $15^{\mathrm{a}}$ ed., São Paulo, Saraiva, 1985, p. 70, classifica as pessoas jurídicas quanto à sua estrutura, dividindo-as naquelas que possuem como elemento subjacente o homem, compondo-se pela reunião de pessoas (universitas personarum), o que ocorre nas associações e aquelas que se constituem em torno de um patrimônio destinado a um fim (universitas bonorum), como as fundações.

${ }^{51}$ Ver O. GoMes, Introdução ao Direito Civil, $7^{\mathrm{a}}$ ed., Rio de Janeiro, Forense, 1983, p. 167.

${ }^{52}$ Ver W. De Barros MonTeIRo, Curso de Direito Civil cit. (nota 42 supra), p. 151.

${ }^{53}$ Ver W. DE BARros MonTEIRO, Curso de Direito Civil cit. (nota 42 supra), p. 151.

${ }^{54}$ Ver M. BASILE, Le persone giuridiche, Milano, Giuffrè, 2003, pp. 3-4, 43-47. O autor explica que por influência da teoria institucionalista, as associações e fundações eram denominadas instituições, termo que significava "qualquer ente ou corpo social que possua um assento estável e permanente e forme um próprio corpo com vida própria". Assim como na categoria sócio-política de organização, também na jurídica de "ente" se encaixam múltiplas figuras, as associações, fundações e outras instituições, o que dá margem à formação de espécies de entes diferentes daqueles regulados expressamente e deixa espaço para o legislador criar outros tipos de organismos sociais. Isso não exclui a presença de importantes elementos comuns ou de analogia significativa entre os diversos organismos que se enquadram na categoria geral.
} 
Para M. BASILE, em relação aos meios patrimoniais, nenhum escopo pode ser perseguido sem recursos financeiros, sendo também importante que toda organização possa garantir, com bens adequados, os seus credores. Em razão disso, o sistema reconhece aos entes a idoneidade de serem titulares de meios patrimoniais, sendo o reconhecimento da subjetividade jurídica válido também para os grupos não personificados, como as associações não reconhecidas. $\mathrm{O}$ ente deve usar o patrimônio de forma a perseguir o fim escolhido por quem o conferiu. Para as associações que quiserem adquirir a personalidade jurídica é necessário indicar o seu patrimônio no ato constitutivo e no estatuto, sendo suficiente para garantir ao ente a consecução do fim, cabendo à autoridade administrativa o juízo da adequação do patrimônio ${ }^{55}$.

Portanto, percebemos que o elemento pessoal é o mais relevante nas associações, enquanto que nas fundações predomina o elemento patrimonial. Esta constatação ocasionou uma discussão na doutrina acerca da necessidade de patrimônio para que a associação possa se constituir validamente.

O Código Civil italiano não determina de que forma deve ser constituído o patrimônio das associações. Parte da doutrina não admite a criação do ente sem patrimônio, apenas com uma expectativa genérica de contribuições futuras de terceiros. Contudo, é possível garantir a formação do patrimônio associativo dispondo que seja constituído com contribuições dos associados. No caso das associações não reconhecidas, o legislador se limita a prever a existência de um fundo comum, composto pelas contribuições dos inscritos e pelos bens por eles adquiridos, sem subordinar a validade ou eficácia do ato constitutivo ao empenho dos seus autores de fornecer ao grupo as referidas contribuições. Nesse caso é prevista a responsabilidade pessoal e solidária de quem age em nome do grupo. Para alguns, essa regra torna supérfulo o requisito do patrimônio nas associações não reconhecidas, com o que M. BASILE discorda ${ }^{56}$.

F. GALGANO, fazendo referência ao direito romano medieval, explica que a associação era definida como universitas personarum e a fundação como universitas bonorum. A primeira consistia numa pluralidade de pessoas unidas para o alcance de uma finalidade comum, enquanto que a segunda é um complexo de bens destinado ao alcance

\footnotetext{
${ }^{55}$ Le persone giuridiche cit. (nota 54 supra), p. 102-110.

${ }^{56}$ Le persone giuridiche cit. (nota 54 supra), pp. 104-107 e 109-110. Para o autor, pode-se presumir um princípio que os associados devam contribuir para alcançar o objeto social das regras do contrato em geral, exigindo o sistema jurídico que os meios patrimoniais dos entes sejam utilizados para realizar os seus escopos.
} 
de uma finalidade comum. Sendo assim, para se definir o gênero do qual associação e fundações são espécies, é necessário se empregar o conceito de instituição, que designa todo ente ou corpo social, ou seja, todas as relações entre diversos sujeitos da qual se origine uma estrutura supersocial, ou ainda se pode empregar a expressão 'formação social', ou seja, um grupo social intermediário entre o indivíduo e a sociedade ${ }^{57}$.

Para o autor, tanto associações quanto fundações são expressões da autonomia negocial e surgem através de um negócio jurídico. A primeira através do contrato de associação, sendo a atividade voltada a atingir o objetivo comum dos membros a atividade executiva dos respectivos negócios constitutivos. Trata-se, portanto, de um negócio de organização, ou seja, de negócio jurídico cuja execução implica na constituição de uma estrutura organizativa. Contudo, os negócios constitutivos de associações e fundações possuem diferentes naturezas e modos diversos de execução. A fundação pode, diferentemente da associação, ser constituída por apenas uma pessoa, enquanto que o ato constitutivo da associação é sempre um contrato ${ }^{58}$.

As partes do contrato de associação concorrem na administração da mesma, sendo diversas as formas de participação dos associados em sua atividade, nas várias manifestações do fenômeno associativo e em relação às várias categorias de integrantes. Permanecerá, em qualquer caso, o poder do associado, senão de participar diretamente da gestão, de influenciar indiretamente em seu desenvolvimento. Normalmente, na execução do contrato de associação participam as mesmas pessoas que a constituíram ${ }^{59}$.

$\mathrm{Na}$ associação a destinação do patrimônio ao escopo é objeto de uma obrigação contratual. Os membros da associação - partes da relação contratual - dispõem, em relação à destinação do patrimônio da associação, a mesma autonomia que é própria das partes de todos os contratos. Os administradores das associações e fundações cumprem uma função, exercendo poderes originários, que derivam do estatuto da pessoa jurídica, sendo que as atribuições dos administradores das associações encontram um limite nas competências das assembleias dos associados ${ }^{60}$.

Para F. KüBLER, a diferença estrutural existente entre a sociedade personalista (ou sociedade em sentido estrito) e a corporação se revela, dentro do direito civil alemão, nos tipos contrapostos de sociedades e da associação com capacidade

\footnotetext{
${ }^{57}$ Persone giuridiche, Bologna, Nicola Zanichelli Editore, 1969, pp. 68-74.

${ }^{58}$ Persone giuridiche cit. (nota 57 supra), pp. 68-74.

${ }^{59}$ F. Galgano, Persone giuridiche cit. (nota 57 supra), pp. 68-74.

${ }^{60}$ F. GAlgANO, Persone giuridiche cit. (nota 57 supra), pp. 68-74.
} 
jurídica. As corporações (em especial as associações e as sociedades de capital) se concebem como uma união de pessoas de maior envergadura, que transcende além da permanência de seus membros. As associações e as sociedades jurídicas de capital têm um regime jurídico corporativo, e necessitam de um nome para operar no tráfico jurídico e de um estatuto, no qual se fixa a sua estrutura organizativa ${ }^{61}$.

A estrutura corporativa representa uma separação estrita entre os membros isoladamente considerados e a associação ou sociedade capitalista. Para isso, a lei confere capacidade jurídica à corporação, que se torna pessoa jurídica e é juridicamente titular do patrimônio da associação ou sociedade, inclusive das dívidas. Somente a corporação é proprietária do seu patrimônio, e seus membros apenas dispõem de direitos derivados de sua condição como tais, não respondendo pelas dívidas da associação ou sociedade anônima ${ }^{62}$.

A corporação é, simultânea e necessariamente, sociedade interna e externa, pois produz efeitos jurídicos em todos os planos. As relações internas são aquelas produzidas entre os associados. As relações externas são as existentes entre sociedade e terceiros ${ }^{63}$.

Concluímos, assim, que nas associações predomina o elemento pessoal, enquanto que nas fundações predomina o elemento material. O patrimônio não é indispensável para a constituição das associações, e estas são criadas por um grupo de pessoas, formando um patrimônio comum, grupo este que as administra, visando sempre o escopo determinado. O substrato das associações é o grupamento de pessoas, que se reúnem para buscar uma finalidade pré-determinada por elas, enquanto que o das fundações é um complexo de bens, com o objetivo de atingir uma finalidade determinada pelo instituidor.

\footnotetext{
${ }^{61}$ Derecho de Sociedades, 5a ed. rev. y ampliada, trad. M. KLEIN, Madri, Fundación Cultural del Notoriado, 2001, pp. 59-60, 62-63.

${ }^{62}$ F. KÜBLER, Derecho cit. (nota 61 supra), p. 63.

${ }^{63}$ F. KÜBLER, Derecho cit. (nota 61 supra), p. 65.
} 
I.3. O fim das associações. A ausência de finalidade lucrativa. Distinção entre finalidade econômica e lucrativa. Possibilidade de exercício de atividade econômica. As associações empresariais

Como já mencionamos, as associações são conceituadas como uma união de pessoas que se organizam para fins não econômicos ${ }^{64}$.

Os associados não podem, portanto, buscar uma finalidade que seja equivalente à repartição de eventuais resultados lucrativos. Contudo, devemos analisar se a associação pode exercer uma atividade econômica, e, caso a resposta seja afirmativa, de que forma poderá ser desempenhada, bem como concluir se isso não desvirtuaria o sentido do ente coletivo organizado para fins não econômicos.

Iniciaremos a nossa análise tratando do conceito de fim dos entes coletivos, e da forma como ele deve ser pré-determinado no estatuto e como as atividades da associação devem ser orientadas para buscá-lo.

Todas as associações perseguem um determinado escopo, que deve constar do seu ato constitutivo, de forma expressa, para poder ser avaliado pela autoridade administrativa, caso as entidades aspirem à concessão de personalidade jurídica. Tal avaliação permitirá à associação obter o reconhecimento e o registro ${ }^{65}$.

Além disso, o fim delimita os confins da legitimidade da gestão dos órgãos de administração, representando os parâmetros sobre os quais se estabelecerá - por ter sido o fim atingido ou por ter se tornado impossível - que o ente deverá ser extinto. Constitui também o critério para escolher os destinatários dos bens remanescentes após a liquidação ${ }^{66}$.

O escopo de um ente é definido na síntese dos interesses que este objetiva realizar e das respectivas atividades para alcançá-los. O fim indica a atividade da entidade, pelo menos a principal, enquanto algumas vezes evidencia o interesse cuja realização é perseguida através dela - atividade -, direta ou indiretamente. Afirma-se que o escopo das

\footnotetext{
${ }^{64}$ Ver artigo 53 do Código Civil.

${ }^{65}$ Ver M. BASILE, Persone giuridiche cit. (nota 54 supra), pp. 68-69.

${ }^{66}$ Ver M. BASILE, Persone giuridiche cit. (nota 54 supra), p. 69.
} 
associações deve ter caráter não lucrativo, e, portanto, tais entidades seriam organismos sem finalidades lucrativas ${ }^{67}$.

Atividade, segundo R. SzTAJn, é uma série de atos dirigidos para uma mesma finalidade, que mantêm vínculo entre $\mathrm{si}^{68}$.

A atividade empresarial é atividade econômica, uma vez que a empresa é uma organização dessa natureza, predisposta para a produção e circulação de bens e serviços a serem oferecidos em mercado. Entretanto, não é privativo da empresa realizar tal oferta, uma vez que outros profissionais exercem atividades econômicas dirigidas a mercados, ainda que a eles se apliquem outros regimes jurídicos. Nem toda organização da atividade econômica é, portanto, empresa ${ }^{69}$.

F. C. SCAFF menciona que, mesmo em se tratando de caracterização de uma empresa, um dos requisitos deve ser a constituição de atividade econômica, mas não necessariamente esta atividade deve ser lucrativa. Para ilustrar, o autor cita as cooperativas que, por sua própria natureza jurídica e regulamentação legal, não possuem finalidades lucrativas, no que entendemos assemelharem-se às associações. ${ }^{70} 71$

Embora não possa haver distribuição de lucro para os associados, as associações podem exercer atividades econômicas. Podem, portanto, realizar atividades de produção e troca de bens e serviços, uma vez que a liberdade de iniciativa econômica não encontra a princípio limites na natureza do sujeito que a pretende desenvolver. A atividade pode ainda ser exercida de forma direta - quando a própria entidade produz e troca bens ou serviços sem a intermediação de um organismo social - ou indireta, quando as associações, por exemplo, adquirirem quotas de sociedades de capitais, o que é previsto em legislações especiais na Itália ${ }^{72}$.

\footnotetext{
${ }^{67}$ Ver M. BASILE, Persone giuridiche cit. (nota 54 supra), pp. 70-71.

${ }^{68}$ Teoria Jurídica da Empresa, $2^{\mathrm{a}}$ ed., São Paulo, Atlas, 2010, p. 71.

${ }^{69}$ Teoria Jurídica cit. (nota 68 supra), pp. 79-80 e 125.

${ }^{70}$ Teoria Geral do Estabelecimento Agrário, São Paulo, RT, 2001, p. 57.

${ }^{71}$ Ver também F. C. SCAFF, Aspectos Fundamentais da Empresa Agrária, São Paulo, Malheiros, 1997. O autor questiona se a atividade organizada deve ser realizada com o necessário objetivo de lucro, explicando que alguns doutrinadores entendem que a destinação ao mercado é requisito indispensável na configuração do gênero empresa, enquanto outros professam pela consideração objetiva da economicidade, atenuando esta relação dos bens produzidos com o mercado.

${ }^{72}$ Ver M. BASILE, Persone giuridiche cit. (nota 54 supra), pp. 71-75.
} 
A possibilidade de exercício direto de atividades produtivas pelos diversos entes possui restrições, devendo os proveitos ser destinados aos fins da instituição, e nunca aos próprios membros ${ }^{73}$.

H. M. D. VerÇOSA, ao tratar comercialização do direito civil, explica que os agentes econômicos deste ramo do direito não qualificados como empresários recorrem aos contratos historicamente inseridos no plano do direito comercial, recebendo do ordenamento jurídico o mesmo tratamento deste último. Em decorrência disto, outras características dos contratos mercantis se aplicarão aos contratos civis dentro de um processo que vem aos poucos restringindo as fronteiras dos ramos de direito neste campo $\operatorname{particular}^{74}$.

O legislador italiano concedeu liberdade aos membros das entidades para fixar os fins que pretendem buscar, desde que não sejam vedados aos indivíduos pela lei penal. Normalmente os associados colaboram para o alcance de um interesse coletivo próprio, sendo tal colaboração considerada necessária para a realização do fim perseguido. Há uma coincidência entre os sujeitos que possuem os interesses e os sujeitos que executam as atividades ${ }^{75}$.

Para M. BASILE os interesses coletivos dos associados podem ser inclusive de caráter econômico, avaliáveis patrimonialmente. F. GALGANO discorda, pois para ele as associações deveriam ter fins ideais. O primeiro discorda do segundo, pois para ele apesar de as contribuições dos associados de fato não constituírem um investimento, o caráter do escopo comum não deve ser necessariamente ideal. Diverge ainda dos doutrinadores que defendem que o caráter econômico não é dos fins da associação, e sim dos interesses instrumentais ou indiretos dos associados, pois para ele o caráter econômico dos interesses

\footnotetext{
${ }^{73}$ Ver M. BASILE, Persone giuridiche cit. (nota 54 supra), pp. 75-76.

${ }^{74}$ Contratos Mercantis e a Teoria Geral dos Contratos, São Paulo, Quartier Latin, 2010, pp. 26-27.

${ }^{75}$ Ver M. BASILE, Persone giuridiche cit. (nota 54 supra), pp. 76-81. O autor explica que havia uma tese que defendia que os interesses a serem perseguidos por uma associação deveriam ser "de categoria", ou seja, a uma série ampla de categorias de sujeitos, com sentido aberto, distinguindo dos interesses de grupo, que se referem a uma coletividade fechada de sujeitos. Esta dicotomia se baseia na distinção tradicional dos fenômenos associativos do ponto de vista do caráter aberto ou fechado da sua estrutura pessoal. Nas associações, nas cooperativas e consórcios industriais a relação seria, pela sua própria natureza, aberta à possibilidade de novas adesões, enquanto que em outros grupos como as sociedades lucrativas, a adesão de novos membros ficaria submetida a vários limites. Contudo, uma objeção ao caráter "aberto" das associações se dá no referente à transmissão da qualidade de associado, uma vez que não é concedida a terceiros o direito de ser admitido na associação, o que leva o autor a rejeitar a distinção entre sociedade e associação em caráter aberto ou fechado. Para ele, se a estrutura pessoal das associações pode ser aberta ou fechada, ao escopo coletivo podem se incluir interesses de grupo, além dos de categoria. Conclui que as relações associativas podem ser impessoais, ou seja, de sujeitos portadores de interesses pessoais abstratos, para realizar valores comuns a classes ou categorias de indivíduos ou interpessoais, de participantes que realizam valores que são exclusivos ou peculiares a determinadas pessoas.
} 
dos associados repercurte nos fins da associação, que não pode ser tida como de fins ideais nesse caso $^{76}$.

Além disso, o autor entende que o simples interesse não é suficiente para reconhecer as espécies de associações, porque não existe uma correspondência estreita entre o interesse a buscar e a estrutura associativa, não sendo nem mesmo a atividade desenvolvida em comum suficiente para identificar as principais figuras. Conclui, assim, que devem ser levados em consideração para identificar as várias espécies o interesse a ser buscado e a atividade desenvolvida, o que tem como vantagem identificar determinadas figuras associativas correspondentes a específicos fenômenos práticos, embora não sejam especialmente as regras ditadas para cada figura que justificam a opção da identificação pelos fins e atividades ${ }^{77}$.

Sobre a distinção entre a sociedade ou associação de intuitos econômicos e não econômicos, F. C. PONTES DE MiRAnda explica que possui interesse prático, o que pode se notar por ocasião da extinção da entidade. O remanescente do patrimônio social, quando há fins econômicos, se comparte entre os sócios e associados, ou seus herdeiros, enquanto o remanescente da sociedade ou associação de fins não econômicos, salvo regra diferente dos estatutos, é devolvido a estabelecimento municipal, estadual, territorial, distrital ou federal, de fins idênticos, ou semelhantes ${ }^{78}$.

Normalmente os fins das associações devem ser determinados e duradouros, podendo ser múltiplos, desde que sejam homogêneos e conciliáveis ${ }^{79}$.

As associações podem gerar lucros, desde que não os distribuam entre os associados, o que não as desnaturam ou descaracterizam. Podem realizar negócios, praticar atos para manter ou aumentar o seu patrimônio, produzir bens ou prestar serviços. Não perdem, portanto, a categoria de associação mesmo que realizem tais negócios, proibindose somente a distribuição de lucros entre os associados ${ }^{80}$.

F. KÜBLER explica que o BGB distingue entre associações com ou sem fins lucrativos e se a sua finalidade consiste em uma exploração de caráter econômico ou não, formulação que, contudo, já foi taxada de imprecisa pela doutrina alemã. Segundo a

\footnotetext{
${ }^{76}$ Persone giuridiche cit. (nota 54 supra), pp. 68-76.

${ }^{77}$ Persone giuridiche cit. (nota 54 supra), pp. 68-76.

${ }^{78}$ Ver Tratado de Direito Privado cit. (nota 4 supra), pp. 294-295.

${ }^{79}$ Ver R. DE RUGGIERO, Instituições cit. (nota 28 supra), p. 392.

${ }^{80}$ Ver C. R. GonÇAlves, Direito Civil Brasileiro, vol. I, Parte Geral, $2^{\mathrm{a}}$ ed., São Paulo, Saraiva, 2005, p. 201; M. H. DinIZ, Curso de Direito Civil cit. (nota 13 supra), p. 239 e F. AMARAL, Direito Civil cit. (nota 27 supra), pp. 289-290.
} 
opinião dominante a lei proíbe a inscrição no registro de associações cuja finalidade consista em obter, para si ou para seus membros, vantagens do tipo econômico. Por outro lado, é permitida pela entidade a exploração de uma empresa desde que seja um meio para atingir os fins não econômicos. Portanto, a união de pessoas cuja finalidade seja a obtenção de vantagens econômicas pode se inscrever como associação se o meio empregado não constituir uma atividade econômica ${ }^{81}$.

A jurisprudência brasileira - como mencionado nas notas 29 e 30 - tem reconhecido à associação regularmente constituída a capacidade de propor ações coletivas, como a ação civil pública, para tutelar os direitos individuais homogêneos de seus $\operatorname{associados}^{82}$. É permitida a substituição processual nesses casos. Tem-se admitido que a ação poderá ser proposta sem a necessidade de prévia autorização da assembleia de $\operatorname{associados}^{83}$.

Houve uma discussão sobre se a necessidade de as associações incluírem no rol de suas finalidades a defesa dos interesses objetivados na ação civil pública ou coletiva por elas proposta. Concluiu-se que devem possuir finalidades institucionais compatíveis com a defesa do interesse transindividual que pretendam tutelar em juízo. A finalidade, porém, pode ser razoavelmente genérica, não sendo necessário que a associação seja constituída para defender especificamente aquele interesse controvertido na hipótese concreta $^{84}$.

Por fim, para tratar da possibilidade de exercício de atividade empresarial pelas associações, cabe analisar as chamadas associações empresariais francesas, estudadas por S. CASTRO e N. AliX. Na França, muitas associações exercem atividades econômicas. São as denominadas associações empresariais, que possuem estatutos de associação, embora as suas atividades combinadas à sua estrutura e gestão financeira estejam ligadas à economia social e as características de sua organização pertençam às empresas. Os autores ressaltam que tais associações que exercem atividades econômicas se submetem a regras muitas vezes conflituosas ${ }^{85}$.

A associação tem sofrido constantes evoluções, tendo se mostrado como uma forma de organização social que, graças à sua flexibilidade de adaptação, permitiu

\footnotetext{
${ }^{81}$ Derecho de Sociedades cit. (nota 61 supra), pp. 206-207.

${ }^{82}$ Ver nota 29 supra.

${ }^{83}$ Ver nota 30 supra.

${ }_{85}^{84}$ STJ, $1^{\text {a }}$ Turma, AgRg n. 901.936-RJ, rel. Min. Luiz Fux, j. 16-10-2008.

${ }^{85}$ L'Entreprise Associative. Aspects Juridiques de l'Intervention Économique des Associations, Paris, Economica, 1990, pp. 17-18.
} 
encontrar as respostas às necessidades que surgiram, passando por mutações constantes. Passou a atuar no campo econômico, normalmente ocupado por empresas públicas ou sociedades de economia mista, tratando com tal evolução de conceitos como lucro, atividade lucrativa, atividade mercatória e funcionamento da empresa ${ }^{86}$.

A lei francesa de 1901 não previu a utilização extensiva que seria feita da fórmula de grupo que ela instituía, pois não havia preparado a associação para o exercício de atividades econômicas de forma habitual. Era proibida a distribuição dos lucros entre os associados, mas se a atividade da associação os produzisse, eles poderiam ser utilizados no alcance do seu fim. Portanto, a entidade poderia exercer de forma habitual atos de comércio, mas a atividade especulativa não poderia ser o seu objeto, e sim apenas uma atividade meio ao serviço do seu objeto ${ }^{87}$.

As associações que exercem atividades econômicas com fins sociais diferenciam-se das sociedades, que não possuem esta finalidade. A diferença entre elas é a exclusão não de toda finalidade lucrativa, mas de toda divisão de lucros entre os membros. $\mathrm{O}$ conflito mencionado que enfrentam as entidades consiste em fazer com que as associações empresariais possam adotar as mesmas disciplinas e dispor de iguais vantagens, endossando responsabilidades semelhantes às das empresas, embora conservem a sua originalidade fundamental além de alguns privilégios ${ }^{88}$.

Embora a jurisprudência francesa já tenha reconhecido a licitude do exercício pelas associações de atividades econômicas, o estatuto associativo não é uma forma jurídica desejável a priori para desenvolver tais atividades, tanto em relação aos seus próprios interesses quanto em relação aos terceiros que contratam com ela. A associação empresarial seria, assim, um ser híbrido, com estatuto de associação e características de empresa, não sendo uma empresa por inteiro, mas havendo necessidade de aplicação de regras para o exercício habitual de uma atividade comercial. Contudo, a jurisprudência francesa não parece decidida a criar uma categoria de associações comerciantes $^{89}$.

Como mencionado, a associação francesa não foi criada com a finalidade de constituir uma estrutura econômica, não possuindo capital social e fundos próprios, devendo se submeter a vários riscos para desenvolver suas atividades. Algumas

\footnotetext{
${ }^{86}$ S. CASTRO e N. ALIX, L'Entreprise Associative cit. (nota 85 supra), p. 24.

${ }^{87}$ S. CASTRO e N. ALIX, L'Entreprise Associative cit. (nota 85 supra), pp. 28-32.

${ }^{88}$ S. CASTRO e N. AliX, L'Entreprise Associative cit. (nota 85 supra), p. 34.

${ }^{89}$ S. CASTRO e N. AlIX, L'Entreprise Associative cit. (nota 85 supra), pp. 43-51.
} 
associações ocupam um lugar especial em razão da importância da sua atividade econômica, o que as leva a enfrentar problemas de gestão e de financiamento próprios das sociedades empresárias ${ }^{90}$.

Apesar da associação não estar incluída no direito francês como tipo a ser adotado para quem queira exercer atividades empresariais, suas operações podem levar à prática de atividades econômicas, adotando tais entidades organizações externas e internas em consequência disso, com geralmente todas as características de uma empresa, com objetivo de ser um sujeito no mundo dos negócios ${ }^{91} 92$.

A dificuldade enfrentada por esses entes para exercício da atividade econômica está relacionada ao fato dos seus recursos serem normalmente constituídos pelas contribuições dos associados, doações, legados e fundos próprios. Ocorre que, na falta de fundos próprios, a associação necessita se voltar para outros tipos de recursos possíveis para se constituir e reforçar a sua estrutura financeira. Sua fragilidade financeira está ligada ao seu estatuto e a entidade deve procurar modelos e procedimentos especiais para obter os meios materiais próprios a permitir a realização dos seus objetivos. Às subvenções das pessoas públicas ou semipúblicas e aos recursos mais tradicionais vem se juntar uma imitação das técnicas societárias: o apelo à poupança pelas associações empresariais $^{93}$.

As associações não sofrem, portanto, nenhuma proibição formal para exercer qualquer atividade econômica, desde que não haja uma distribuição direta ou

\footnotetext{
${ }^{90}$ S. CASTRO e N. ALIX, L'Entreprise Associative cit. (nota 85 supra), pp. 51-61. Em 1985, uma lei francesa, em resposta a esses problemas, autorizou a emissão de valores mobiliários para certos tipos de associações. As associações que desejarem emitir os títulos obrigacionais ou associativos devem preencher certas formalidades relevantes ao direito comercial: possuir uma contabilidade, apresentar os documentos contábeis, designar um auditor, assim como se inscrever no registro de comércio e das sociedades. Mas a inscrição no registro comercial só é feita para permitir a emissão dos valores mobiliários, e dura pelo período de pagamento dos títulos. Os autores advertem que se trata de uma formalidade legal que permite o acesso a um meio de financiamento, e não o sinal de um eventual reconhecimento da associação empresarial como um comerciante, ou como um tipo de sociedade empresária.

${ }^{91}$ S. CASTRO e N. ALIX, L'Entreprise Associative cit. (nota 85 supra), p. 91. Como exemplo, os autores citam, em relação ao esporte, que muitas associações constituíam verdadeiras empresas de espetáculo esportivo em razão da atividade desenvolvida, tendo havido a promulgação da Lei 84610 de 1984, que impôs aos clubes esportivos que gerem uma seção profissional de constituir para tal fim e para as suas atividades comerciais uma s.a., controlada pela associação esportiva de base. Depois a lei foi modificada para a criação facultativa da s.a., mas a associação devia inserir nos seus estatutos normas de controle financeiro e responsabilidade patrimonial dos dirigentes, semelhantes às das sociedades de capital. A associação esportiva é considerada, portanto, empresária. A sociedade criada deve ser sem fins lucrativos, filial da associação, que detém a maioria dos votos nos órgãos deliberantes dessa sociedade.

${ }^{92}$ S. CASTRO e N. ALIX, L'Entreprise Associative cit. (nota 85 supra), p. 118. Os juristas italianos, por outro lado, possuem dúvidas quanto à possibilidade das associações exercerem atividades econômicas, tendendo a procurar outras formas jurídicas para fazê-lo, como as cooperativas.

${ }^{93}$ S. CASTRO e N. ALIX, L'Entreprise Associative cit. (nota 85 supra), p. 164.
} 
indireta de benefícios, e que o seu objeto seja outro que não empresarial. Contudo, elas são mal equipadas para exercer tais atividades, especialmente empresariais, tanto no plano do seu funcionamento interno quanto no plano das suas relações com terceiros. Muitas delas adotaram uma forma jurídica justificável no início, mas após passar por um desenvolvimento, tal forma não parece mais suficiente para atingir a plena eficácia das suas atividades e o alcance dos seus objetos. Para essas associações os autores sugerem como soluções a constituição de um grupo ou a transformação ${ }^{94}$.

Os autores defendem que uma associação que evolui em direção de uma sociedade empresária deveria poder decidir formalizar essa transformação e se abrir às novas possibilidades de extensão no plano comercial, suprimindo as limitações sofridas, com a consagração do registro de comércio e das sociedades. O termo transformação, porém, se aplica somente às sociedades, e não parece adequado no caso de mudança de uma associação para sociedade anônima. Portanto, os membros de uma associação empresarial que queiram adotar a forma de sociedade anônima devem, em primeiro lugar, promover a dissolução da associação, ou ainda criar tal sociedade mantendo a associação, vivendo cada uma de forma independente, reduzindo a associação as suas atividades e se tornando sócia da sociedade ${ }^{95}$.

Concluem que o caminho mais viável seria a transformação de uma associação em cooperativa, pois se tratam de dois entes pertencentes ao mesmo universo da economia social, e as diferenças são bem menores do que entre uma associação e uma sociedade de tipo capitalista. Contudo, no estágio atual do direito positivo francês ainda parece ser necessária a dissolução da associação e criação de um novo tipo de cooperativa, embora acreditem que este seja o único caso de transformação de associação em sociedade que poderá ser admitido um dia ${ }^{96}$.

No direito brasileiro, parece não haver restrições ao exercício de uma atividade econômica por parte das associações, que podem auferir lucro, desde que não seja distribuído aos associados, e sim investido na obtenção da finalidade comum. Entendemos que não há proibições para que as associações atuem no mercado financeiro, participando de outras sociedades ou até emitindo títulos, embora não haja previsão legal nesse sentido, como existe no direito francês.

\footnotetext{
${ }^{94}$ S. CASTRO e N. AliX, L'Entreprise Associative cit. (nota 85 supra), pp. 169-170.

${ }^{95}$ S. CASTRO e N. AliX, L'Entreprise Associative cit. (nota 85 supra), pp. 174-175

${ }^{96}$ S. CASTRO e N. AlIX, L'Entreprise Associative cit. (nota 85 supra), pp. 195-196.
} 
Podemos concluir, portanto, que as associações que exercerem atividades empresárias enfrentarão os mesmos problemas que as francesas, não tendo sido concebidas ou estruturadas para funcionar como uma sociedade anônima, e correndo o risco de se desvirtuar do seu escopo. Algumas inclusões nos estatutos, contudo, poderiam ser efetuadas, desde que os membros estivessem de acordo, no sentido de permitir a emissão de títulos, participação em grupos e realização de investimentos no mercado financeiro, o que poderia constituir uma forma de financiamento viável para consecução do escopo, em especial para atividades relevantes de grande alcance social.

\section{I.4. $\mathrm{O}$ ato constitutivo e o estatuto}

Devemos analisar o que se entende por ato constitutivo e estatuto, diferenciando-os, bem como estabelecer o conteúdo mínimo dos estatutos das associações, conforme previsto em lei. Além disso, trataremos dos efeitos vinculativos dos estatutos aos associados.

$\mathrm{O}$ ato constitutivo, como o próprio nome sugere, é o ato pelo qual os associados fundadores manifestam a sua vontade de constituir a associação, enquanto o estatuto trata mais detalhadamente da estrutura do negócio jurídico associativo e das formas de execução para buscar a finalidade comum da entidade. $\mathrm{O}$ estatuto deve conter os requisitos essenciais da associação ${ }^{97}$.

O legislador italiano estabeleceu que as associações que quiserem adquirir personalidade jurídica com o registro devem requerer a sua constituição através de forma solene, estipulando o contrato de associação por ato público. O registro da entidade é necessário para o reconhecimento e para a aquisição da personalidade jurídica. A falta do registro, ou mesmo da forma escrita, não torna nulo o contrato de associação, mas esta não será reconhecida.

Trataremos das associações sem personalidade jurídica em item próprio ${ }^{98}$.

\footnotetext{
${ }^{97}$ Segundo F. Amaral, Direito Civil cit. (nota 27 supra), p. 289: “A parte normativa do ato constitutivo é o estatuto, que pode definir-se como o conjunto das normas de organização e de comportamento da associação e de seus membros."

${ }^{98}$ Ver F. Galgano, Le persone giuridiche cit. (nota 57 supra), pp. 191-192. Sobre as associações não reconhecidas, ver o item II.2.
} 
A formação do ato constitutivo poderá ser simultânea ou progressiva, também denominada continuada. No segundo caso, o vínculo associativo se forma através das adesões sucessivas, nas quais são mencionados os elementos essenciais do contrato de associação. Todos os outros elementos do contrato serão determinados, por maioria, na assembleia dos membros que aderirem à entidade, a denominada assembleia de constituição, na qual os associados agem como árbitros. A ata da assembleia que constitui a associação deverá ser redigida e anexada ao pedido de reconhecimento levado a registro. Já as adesões sucessivas não necessitam de nenhuma forma especial, embora possuam um valor constitutivo de vínculo associativo ${ }^{99}$.

O artigo 16 do Código Civil italiano estabelece o conteúdo obrigatório do ato constitutivo e do estatuto. Normalmente são redigidos em documentos separados. No primeiro, geralmente se manifesta a vontade das partes de darem incoação à relação, enquanto que no segundo são determinadas a estrutura da relação e a modalidade de execução, ou seja, as chamadas normas de funcionamento do ente. As disposições de ambos os documentos compõem, contudo, um único negócio jurídico: o contrato de $\operatorname{associação~}^{100}$.

$\mathrm{O}$ estatuto e o ato constitutivo devem conter os chamados elementos essenciais, sob pena de nulidade. Tais elementos são o objetivo da associação e as condições de admissão dos associados, o que constituiu o regulamento mínimo que corresponde ao conteúdo do ato constitutivo. Os outros elementos essenciais, normalmente colocados no estatuto, podem ser determinados em via de arbitramento. As disposições do ato constitutivo e do estatuto, enquanto disposições negociais, são reguladas pelos princípios gerais do negócio jurídico, exceto as derrogações impostas pela natureza do contrato de associação, em especial a disciplina própria de invalidade do negócio ${ }^{101}$.

Existem, no ato constitutivo e no estatuto, elementos comuns às associações e fundações, e elementos específicos das associações, como os direitos e obrigações dos associados e as condições de sua admissão. Alguns são essenciais e outros facultativos. Os

\footnotetext{
99 Ver F. GAlganO, Le persone giuridiche cit. (nota 57 supra), pp. 192-193. Trataremos das adesões sucessivas no item II.6, referente ao contrato de associação, aberto a novas adesões.

${ }^{100}$ Ver F. GALGANO, Le persone giuridiche cit. (nota 57 supra), pp. 218-220. O autor explica que a separação documental entre ato constitutivo e estatuto não é necessária, podendo o conteúdo do contrato de associação estar no mesmo documento. Se forem documentos distintos, pelo menos um deles deverá conter os requisitos essenciais do contrato de associação previstos no artigo 16 do Código Civil italiano.

${ }^{101}$ Ver F. GAlgano, Le persone giuridiche cit. (nota 57 supra), pp. 220-221. Os associados fundadores, responsáveis pela elaboração do ato constitutivo, podem deixar para um segundo momento a elaboração do estatuto, atribuindo a função a uma assembleia constituída pelos próprios associados, com poderes de deliberar por maioria.
} 
elementos essenciais ao contrato de associação operam como condições de validade do negócio, enquanto outros elementos constituem as condições para a possibilidade de reconhecimento e de aquisição da personalidade jurídica - como a denominação, o patrimônio e a sede do ente -, sendo que a sua falta não impede a associação não reconhecida de operar ${ }^{102}$.

A primeira indicação legislativa imposta como condição para o reconhecimento do ente é a denominação. As associações estão sujeitas a um regime de publicidade, necessitando de um elemento sintético de identificação do ente. Uma vez escolhida, a denominação é objeto de um direito da associação, tutelável da mesma forma que o nome para as pessoas físicas ${ }^{103} 104$.

O segundo elemento essencial é o fim. A autoridade administrativa não pode fazer nenhum juízo de mérito sobre a finalidade perseguida pela associação, devendo apenas apreciar se a finalidade é lícita, ou seja, que não seja contrária a normas legais imperativas e se enquadre no rol de objetivos a perseguir, de acordo com a lei, por uma $\operatorname{associação~}^{105106107 .}$

${ }^{102}$ Ver F. GALGANO, Le persone giuridiche cit. (nota 57 supra), pp. 222-223.

${ }^{103}$ Ver F. GALGANO, Le persone giuridiche cit. (nota 57 supra), pp. 223-224.

${ }^{104}$ Ver também F. AMARAL, Direito Civil cit. (nota 27 supra), p. 289: "A denominação é o nome da pessoa jurídica. Como tal, é objeto de proteção jurídica (Código Civil, art. 52)".

${ }^{105}$ Ver F. Galgano, Le persone giuridiche cit. (nota 57 supra), p. 225. O autor explica que o âmbito de fins para uma associação é vasto, pois compreende qualquer finalidade de natureza ideal ou não econômica.

${ }^{106}$ Ver C. A. DA MOTA PINTO, Teoria Geral cit. (nota 9 supra), p. 272. O autor explica que a pessoa jurídica deve prosseguir uma certa finalidade, justamente o fim ou a causa determinante da formação da coletividade social ou da dotação fundacional. Em relação às associações, se concebe a sua constituição para a prática de um só ato de tal magnitude que torne necessário o concurso de meios e atividades de várias pessoas.

${ }^{107}$ Ver ainda R. DE RUGGIERO, Instituições cit. (nota 28 supra), p. 392, acerca dos fins das organizações de pessoas ou bens: “(...) Que a coletividade tenha um fim e um patrimônio e que esse fim deva ser lícito, é intuitivo, visto o Estado não poder tolerar que surgissem e operassem no seu território entidades, dotadas de capacidade jurídica, que se destinassem a fins ilícitos, imorais ou perigosos para a ordem pública ou que contrastassem com o ordenamento social ou jurídico. É principalmente neste ponto que a intervenção do Estado na constituição, ou pelo menos na ação das pessoas jurídicas, se legitima e justifica, uma vez que ainda que o reconhecimento não seja um requisito da própria existência da entidade, não se pode prescindir da autorização do Estado (quer seja expressa, quer seja tácita, isto é: desde que não impeça à coletividade o exercício de sua ação), autorização essa dada em virtude do fim, que não pode ir de encontro aos fins universais que a sociedade do Estado representa. (...) É inadmissível um fim individual, visto contratar com a própria razão de ser das pessoas jurídicas, não se admitindo a constituição de um organismo complexo para a consecução de um fim que não interessa uma pluralidade maior ou menor de pessoa. É porém indiferente que a pluralidade se tenha em consideração como um grupo de particulares ou como uma parte do consórcio social. Que o fim não deva ser necessariamente uma utilidade pública, demonstra-o o fato de muitos entes coletivos (como por exemplo as associações profissionais, as sociedades de socorros mútuos, as fraternidades, as caixas de pensões constituídas como corpos morais) não olharem senão à utilidade de seus membros (...). O fim deve ser igualmente duradouro e não meramente transitório. Isso não significa que para que exista uma pessoa jurídica seja preciso um fim perpétuo ou temporariamente indefinido. Se em regra ele é perpétuo, há no entanto entes coletivos que costumam criar-se e fundações que se instituem para o conseguimento de fins e para a satisfação de necessidades que não se renovam perpetuamente. (...), mas que são determinados e finitos (...) O fim deve ser duradouro e permanente no sentido que não justificaria a 
Já a determinação do objeto não é prevista pela lei como requisito essencial do ato constitutivo. A relação na associação é identificada pela finalidade, podendo os seus órgãos, a princípio, exercer qualquer atividade que pareça abstratamente idônea a perseguir, ainda que em via mediata, o fim enunciado pelo ato constitutivo. Normalmente se prevê, contudo, nos estatutos, não só a finalidade do ente, como também os meios para o seu alcance, ou seja, as atividades avaliadas pelo estatuto como as mais idôneas para atingir o fim. Isso tornará tais atividades obrigatórias para os órgãos do ente, mas não impede que sejam executadas outras atividades que pareçam ser idôneas ao alcance do fim $^{108} 109$.

As atividades exercidas pelas associações podem ser econômicas ou não econômicas, devendo as primeiras ser exercidas para a obtenção dos escopos ideais próprios da entidade ${ }^{110}$.

O terceiro elemento essencial é o patrimônio, que deve ser descrito de forma analítica no estatuto, constituindo também um elemento que devem possuir as associações que queiram obter personalidade jurídica. Contudo, uma associação pode até viver sem patrimônio, como no caso em que a finalidade seja buscada somente pela atividade pessoal dos associados. Não há critérios qualitativos ou quantitativos para o patrimônio, mas para que a associação seja reconhecida, é necessário que possua patrimônio suficiente para a consecução do objeto social, o que, em si, já configura um critério quantitativo. Contudo, para F. GALGANO, deveria ser suficiente para o reconhecimento a menção aos meios que serão empregados para a consecução dos fins, em especial se a associação tiver por objetivo uma atividade econômica ${ }^{111}$.

criação de um novo organismo um fim que se conseguisse facilmente e de uma só vez, mediante o esforço de uma pessoa. Igualmente o fim não poderia ser indeterminado; à destinação do patrimônio faltaria a base.”

${ }^{108}$ Ver F. GALGANO, Le persone giuridiche cit. (nota 57 supra), p. 234. Para o autor, a noção de objeto para as associações não possui a mesma importância que para as sociedades. O estatuto pode, contudo, estabelecer um rol taxativo de atividades e proibir expressamente o desenvolvimento de algumas. Nesse caso, os poderes dos órgãos encontrarão limites, semelhantes àqueles impostos, no caso das sociedades, ao objeto social.

${ }^{109}$ Ver também L. FRANÇA, Instituições de Direito Civil cit. (nota 49 supra), p. 75, que explica que a atividade social deve se endereçar exclusivamente aos fins (explícitos e implícitos) da entidade, sob pena de extinção.

${ }^{110}$ Ver F. GALGANO, Le persone giuridiche cit. (nota 57 supra), pp. 234-236. Sobre o exercicio das atividades econômicas pelas associações, ver o item I.3 supra.

${ }^{111}$ Le persone giuridiche cit. (nota 57 supra), pp. 244-253. O autor explica que o Código Civil italiano vigente não adotou a hipótese de constituição e reconhecimento de associação sem patrimônio, exigindo que a entidade, para ser registrada, tenha um patrimônio, o que talvez tenha sido feito para cumprir a finalidade de garantia do pagamento das obrigações assumidas. No caso das associações não registradas, sem personalidade jurídica, a garantia é suprida pela responsabilidade ilimitada imposta aos administradores. 
O quarto elemento essencial que deve ser previsto nos estatutos é a sede, constituindo também condição de reconhecimento para as associações. Da mesma maneira, isso ocorre em razão do regime de publicidade a que as associações se submetem ${ }^{112}$.

Os estatutos devem conter, ainda, normas sobre a organização e a administração das associações. Deve ser determinada a composição do órgão administrativo e a forma de nomeação dos seus componentes, mencionando quais deles possuirão o poder de representação do ente ${ }^{113}$.

O legislador brasileiro também estabeleceu os elementos essenciais das associações. O estatuto deverá conter: a denominação, os fins e a sede; os requisitos para a admissão, demissão e exclusão de associados; os direitos e deveres dos associados; as fontes de recursos para a sua manutenção; o modo de constituição e funcionamento dos órgãos deliberativos; as condições para a alteração das disposições estatutárias e para a dissolução; a forma de gestão administrativa e de aprovação das respectivas contas ${ }^{114}$.

Caso o estatuto da associação não contenha os itens enumerados acima, poderá ser declarado nulo. F. C. PONTES DE MiRANDA adverte, contudo, que não é causa de nulidade ou ineficácia da inscrição ou, sequer, do ato constitutivo, a falta de indicação do destino dos bens das associações de intuitos não econômicos ${ }^{115}$.

Temos que, embora a lei tenha previsto a sanção de nulidade para o caso de ausência dos elementos essenciais, muitos dos requisitos previstos parecem ser verdadeiros elementos categoriais do negócio jurídico - próprios do negócio jurídico associativo - cuja ausência não deveria acarretar a nulidade, e sim a inexistência. Indagamos se a sanção da nulidade não seria incompatível para o caso, se pensarmos na aplicação do princípio da conservação para o negócio jurídico associativo.

Poderia-se aplicar o princípio da conservação do negócio jurídico para evitar a decretação da nulidade de todo o ato e atingir apenas uma de suas cláusulas.

\footnotetext{
${ }^{112}$ Ver F. GALGANO, Le persone giuridiche cit. (nota 57 supra), pp. 253-254.

${ }^{113}$ Ver F. GALGANO, Le persone giuridiche cit. (nota 57 supra), p. 254. Para o autor, qualquer outro elemento de organização deriva da aplicação de regras legais, tornando desnecessárias outras disposições estatutárias. Contudo, é freqüente que os estatutos formulem outras regras de organização, seja em relação ao funcionamento do órgão de administração, seja acerca das assembleias, bem como é usual que se criem outros órgãos, não previstos na lei, como órgãos de controle, correspondentes ao conselho fiscal nas sociedades e colégios arbitrais, com a finalidade de resolver as controvérsias sobre a interpretação e aplicação do estatuto. Sobre os órgãos das associações, ver o item IV.1.

${ }^{114}$ Ver artigo 54 do Código Civil de 2002.

${ }^{115}$ Ver Tratado de Direito Privado cit. (nota 4 supra), pp. 364-365.
} 
Em relação à sua eficácia dos atos constitutivos e estatutos, eles vinculam não só os associados que constituíram a associação, como também os futuros, que a ela aderiram após a sua constituição e registro. Caso os associados desejem alterar as disposições estatutárias, deverão obedecer ao quanto disposto nele para proceder à reforma, no tocante ao procedimento e ao quorum necessários. Normalmente essa deliberação é atribuída à assembleia ${ }^{116}$.

Além disso, podem ser incluídas normas programáticas, dando diretrizes que deverão ser realizadas por algum órgão da associação ${ }^{117}$.

Deve haver, ainda, regras acerca do procedimento de exclusão dos associados, desde que haja justa causa, assegurando o direito de defesa e de recurso ${ }^{118}$.

O estatuto, portanto, deverá dispor não só sobre as regras de admissão, demissão e exclusão dos associados, desde que haja justa causa, como também estabelecerá o procedimento adequado para que se proceda à exclusão ${ }^{119} 120$.

Por fim, deverão ser especificados os direitos e funções conferidos aos associados, disciplinando os casos e as formas pelas quais ficarão impedidos de exercê$\operatorname{los}^{121}$.

\footnotetext{
${ }^{116}$ Sobre a eficácia do ato constitutivo e seus estatutos, ver F. C. PONTES DE MIRANDA, Tratado de Direito Privado cit. (nota 4 supra), pp. 366-367: "O ato constitutivo e seus estatutos, que são parte dele, ou ele mesmo, obrigam os membros que os votaram, os que ingressaram durante a feitura (ou ainda não tinha direito de voto) e os membros posteriormente admitidos. Ainda para os reformar, é preciso que se observem as regras estatutárias sobre reformabilidade. Se a reforma não é possível, porque se pré-excluiu, pode-se extinguir a pessoa jurídica e constituir-se outra; não reformar-se o que é estatutariamente irreformável. Os estatutos, atribuindo à assembleia, ou órgão que se haja de considerar assembleia, a deliberação sobre reforma dos estatutos, retira da unanimidade tal deliberação, se não continua de exigi-la à própria assembleia. (...) As regras estatutárias são como regras jurídicas internas, sem que se façam regras jurídicas: são normas negociais, cláusulas, conteúdo negocial, ainda quando os figurantes do ato constitutivo transfiram a alguns a reforma dos estatutos. Os figurantes submeteram-se à organicidade da pessoa jurídica. (...)"

${ }^{117}$ F. C. PONTES DE MIRANDA, Tratado cit. (nota 4 supra), p. 398.

${ }^{118}$ Ver artigo 57 do Código Civil de 2002. A exclusão dos associados e o que se entende por justa causa serão tratados no item IV.10.

${ }^{119}$ Ver F. AMARAL, Direito Civil cit. (nota 27 supra), p. 290, acerca da admissão, demissão e exclusão dos associados: "O estatuto fixa também os requisitos para a admissão, demissão e exclusão de associados, isto é, o surgimento, modificação e extinção da relação associativa. O associado é titular de uma situação jurídica complexa que nasce do próprio ato constitutivo ou, se a associação é já existente, do negócio jurídico de admissão, isto é, da adesão do interessado aceita pela entidade. A admissão pressupõe o cumprimento de determinados requisitos pelo interessado, que se obriga ao cumprimento das disposições estatutárias. Do mesmo modo que o associado tem o poder de associar-se, no exercício da liberdade constitucional de associação para fins lícitos, tem também o direito de retirar-se, desfazendo unilateralmente a relação associativa, o que faz por meio de sua demissão, ato voluntário pelo qual se retira da associação. Nenhum associado pode ser impedido de exercer esse direito, assim como qualquer função que the tenha sido legitimamente deferida (Código Civil, art. 58). Pode, todavia a associação condicionar a aprovação do pedido de demissão ao cumprimento dos deveres estatutários até aquele momento."

${ }^{120}$ F. U. COELHO, Curso de Direito Civil cit. (nota 10 supra), p. 252, explica que existem diversas sanções previstas no estatuto para o descumprimento de deveres estatutários, desde a simples advertência, à suspensão temporária, até a exclusão.
} 
O ato constitutivo e o estatuto desenvolvem uma função de ordenação, qual seja, de estabelecer as regras de organização do ente, as funções, os direitos e as obrigações dos sujeitos titulares dos interesses e autores da atividade programada. Neles deverão estar contidas, portanto, as normas de organização e administração da pessoa jurídica. As regras de organização interna, que não consistam em normas inderrogáveis, podem derivar de outras fontes. Já a disciplina da organização interna das associações não reconhecidas é remetida aos acordos de associados, que compreendem indiferentemente o ato constitutivo, o estatuto, e outras fontes ${ }^{122}$.

Pode haver, também, no negócio constitutivo, menção à escolha de requerer ou não a concessão da personalidade jurídica. Caso a entidade aspire à concessão da personalidade jurídica, deve haver no ato constitutivo menção ao seu patrimônio. Existem elementos essenciais e outros facultativos que devem ou podem estar previstos, como, no caso de extinção da associação, a escolha dos sujeitos a quem devolver os bens que sobrarem após a liquidação do patrimônio ${ }^{123}$.

Além de elementos essenciais acerca do conteúdo, existem requisitos de forma. As associações e todos os outros entes que aspirem à obtenção de personalidade jurídica devem se constituir por ato público. Por o outro lado, o Código Civil italiano não prescreve nenhuma forma para o ato constitutivo das associações que não aspiram à obtenção da personalidade jurídica ${ }^{124}$.

$\mathrm{Na}$ França, o legislador estabelece que os estatutos das associações devem, no mínimo, determinar a denominação, o objeto, a sede e as condições normais de funcionamento. Podem ser previstas diversas categorias de membros e é necessária a previsão dos órgãos dirigentes, das condições de funcionamento das assembleias e de modificação dos estatutos ${ }^{125}$.

Y. GUYON explica que o legislador francês impõe a colocação de determinadas indicações nos estatutos, no caso das sociedades, o que se aplica também para as associações. Outras estipulações podem ser inseridas, através da aplicação do princípio da liberdade contratual. Uma disposição não será proibida a não ser que a lei

\footnotetext{
${ }^{121}$ Ver artigo 58 do Código Civil de 2002.

${ }^{122}$ Ver M. BASILE, Persone giuridiche cit. (nota 54 supra), pp. 56-57. O autor, quando se refere a outras fontes, menciona as leis de setores específicos, como das organizações de voluntariado, de promoção social e organizações de utilidade social.

${ }^{123}$ Ver M. BASILE, Persone giuridiche cit. (nota 54 supra), pp. 56-57.

${ }^{124}$ Ver M. BASILE, Persone giuridiche cit. (nota 54 supra), p. 57.

${ }^{125}$ P. DELAMARRE, Créer e faire vivre cit. (nota 37 supra), pp. 27-32.
} 
preveja que ela é nula, hipótese em que, se mesmo assim for inserida, será reputada como não escrita. Se os estatutos não contiverem as disposições obrigatórias, a associação não poderá ser registrada $^{126}$.

$\mathrm{Na}$ maior parte dos direitos estrangeiros as sociedades e associações são regidas por dois atos - ato constitutivo e estatuto -, inclusive nos países integrantes da União Europeia. Na França, contudo, existe uma concepção mais unitária, bastando a assinatura de um estatuto para que os associados materializem a sua vontade de participar da sociedade ou associação que se constitui. Os estatutos podem ser completados com anexos - como o regulamento interno -, que possuem, entre os associados, a mesma natureza e autoridade que os primeiros, podendo ser modificados da mesma forma. Considera-se, em caso de conflito, que o regulamento interno possui uma autoridade infraestatutária $^{127}$.

Como as disposições legais não regulam o conteúdo dos atos de forma taxativa, os associados podem completar o seu regime, inserindo cláusulas que possuam a mesma autoridade que as referidas disposições. Deve ser suprimida, contudo, reputando-se como não escrita pela lei, ou seja, como juridicamente inexistente, a disposição que for incompatível com o direito comum das associações ou com o estatuto daquela forma, o que traz a vantagem de não se afetar a validade da própria associação ${ }^{128}$.

Os complementos são normalmente feitos pelo estatuto, seja na constituição da associação, seja no decorrer da vida social. Se as alterações aumentarem as obrigações dos associados, devem ser aceitas por unanimidade. As outras modificações podem ser feitas nas condições normais, mesmo se restringirem os direitos dos associados. As decisões das cortes francesas mais recentes, contudo, têm proibido à coletividade dos associados diminuir os seus direitos ${ }^{129}$.

Os complementos ao regime legal podem figurar tanto nos estatutos quanto em acordos extraestatutários. A segunda forma tem como vantagem a flexibilidade e a confiabilidade, mas apresentar problemas de eficácia. As convenções extraestatutárias possuem natureza contratual e vinculam apenas os seus signatários, mas não são oponíveis à associação, nem aos adquirentes de direitos sociais, a não ser que eles as aceitem

\footnotetext{
${ }^{126}$ Les Sociétés - Aménagements Statutaires et Convention entre Associés, $2^{\mathrm{a}}$ ed., Paris, 1995, p. 29.

${ }^{127}$ Ver Y. GuYON, Les Sociétés cit. (nota 126 supra), p. 31.

${ }^{128}$ Ver Y. GuYON, Les Sociétés cit. (nota 126 supra), pp. 141-142.

${ }^{129}$ Ver Y. GuYON, Les Sociétés cit. (nota 126 supra), pp. 143-144.
} 
expressamente. Para vincular todos os associados é preferível que as disposições sejam inseridas nos estatutos ${ }^{130}$.

Os estatutos podem, portanto, completar a lei, impondo aos associados obrigações suplementares ou lhes conferindo direitos extralegais. Admitem-se como válidas as obrigações impostas aos associados pelos estatutos, desde que se submetam a duas condições: as obrigações devem ser criadas de acordo com o interesse social e os associados devem aceitar individualmente essas obrigações suplementares ${ }^{131}$.

Discute-se se as obrigações estatutárias devem respeitar o princípio de igualdade entre os associados. Para Y. GUYON, embora por um lado o princípio da igualdade seja um dos fundamentos do direito das sociedades e associações, por outro a sua ruptura parece legítima pelo consentimento dado individualmente pelos associados capazes. $\mathrm{O}$ estatuto pode exigir uma condição para a aquisição da qualidade de associado, desde que tal condição não seja discriminativa ${ }^{132}$.

O legislador francês autoriza expressamente a introdução de cláusulas de exclusão do associado faltoso. Algumas dessas disposições se assemelham às cláusulas resolutivas, sendo válidas se colocadas nos estatutos e aceitas por todos os associados. Para serem consideradas válidas, devem preencher três condições, quais sejam: garantias morais, procedimentais e patrimoniais acordadas entre os interessados. Os motivos de exclusão devem ser especificados e aplicáveis a todos os associados, relacionando-se ao comportamento deles e aos problemas que possa causar à vida social, sempre respeitando os direitos da defesa e o princípio do contraditório. Deve ser designado o órgão competente a pronunciar a sanção e organizado o procedimento a ser seguido, prevendo, no mínimo, que o interessado seja convocado em tempo hábil e possa ser ouvido se assim desejar ${ }^{133}$.

Portanto, o autor entende que os estatutos podem completar, de diversas formas, os direitos reconhecidos em lei aos associados, sendo o único limite implícito a obrigação de respeitar a igualdade entre eles. As cláusulas podem desenvolver tais direitos, reforçando-os ou mesmo criando novos tipos, mas os estatutos não podem suprimir os direitos conferidos pela lei ${ }^{134}$.

\footnotetext{
${ }^{130}$ Ver Y. GUYON, Les Sociétés cit. (nota 126 supra), p. 144.

${ }^{131}$ Ver Y. GuYON, Les Sociétés cit. (nota 126 supra), pp. 144-145.

${ }^{132}$ Les Sociétés cit. (nota 126 supra), pp. 145-149.

${ }^{133}$ Ver Y. GuYON, Les Sociétés cit. (nota 126 supra), pp. 152-154.

${ }^{134}$ Ver Les Sociétés cit. (nota 126 supra), pp. 156-164 e 175-177. O autor explica que, em muitos casos, a lei delega ainda aos estatutos o poder de desenvolver os direitos dos associados. Podem, nesse sentido, ser
} 
Podem por outro lado ser conferidos aos associados direitos que a lei não previu, desde que se situem no prolongamento do objetivo essencial das associações, a não divisão dos lucros. Essas criações devem respeitar a igualdade entre os membros das entidades $^{135}$.

$\mathrm{Na}$ Argentina o legislador também fixou os elementos essenciais que o estatuto das associações deve conter: nome; domicílio; fim; composição do conselho diretivo, atribuições e deveres, duração do mandato, procedimento para designação dos membros; regime de modificação do estatuto; data de fechamento do exercício social anual; causas de dissolução, regime de liquidação e destino dos bens sociais ${ }^{136}$.

Identificamos, assim, os elementos essenciais que devem ser previstos nos estatutos das associações, que vinculam os associados que a constituíram e os futuros. Existem ainda os elementos facultativos, possuindo os associados liberdade para completar o estatuto, desde que não estabeleçam regras contrárias à lei, às normas imperativas, à finalidade não lucrativa das entidades ou ao princípio da igualdade entre eles, a não ser que haja, em relação ao último, concordância unânime.

Por fim analisamos os estatutos de algumas associações brasileiras, pertencentes a instituições diversas, como clubes esportivos, de lazer, institutos culturais, associações de ex-alunos de universidades e organizações ambientais.

Os estatutos prevêem, normalmente, que a entidade é uma associação sem fins lucrativos ${ }^{137}$ com prazo de duração indeterminado.

São previstas as diversas categorias de associados, sendo que alguns estatutos analisados especificam o que se entende por cada uma delas - podendo cada

previstas as condições em que as participações dos membros serão cedidas. Normalmente os estatutos restringem as condições de cessão das participações sociais, estabelecendo condições mais severas para cessionários que não sejam associados. Já o direito de voto, em razão de sua importância, é questão de ordem pública. Em casos excepcionais, pode ser suprimido, quando, por exemplo, um sócio ou associado não tiver efetuado os seus aportes na sociedade ou associação ou quando não tiver prestado a sua contribuição. Já os direitos menos essenciais parecem poder ser restritos ou suprimidos pelos estatutos, no interesse da associação e na condição de respeito da igualdade entre os associados. Mas é difícil, no entendimento do autor, saber se um direito é essencial e intangível, ou ao contrário suscetível de alterações.

${ }^{135}$ Ver Y. GUYON, Les Sociétés cit. (nota 126 supra), pp. 171-172. Como exemplo, o autor cita o direito de retirada, que permite a um associado de redimir os seus direitos sociais a qualquer momento pelos outros associados ou pela sociedade. Pode deixar a sociedade sem a necessidade de encontrar um adquirente. Os estatutos devem fixar as condições de exercício do direito de retirada, prevendo se ele será discricionário ou motivado, se o associado deverá dar um aviso prévio e de quanto tempo, como esse direitos serão repartidos entre os associados que permanecerem na associação, etc. O autor entende que deve ser evitada a faculdade de retirada discricionária, para pelo menos garantir um recurso à justiça em caso de abuso.

${ }^{136}$ M. DANIELIAN e J. I. B. PERET, Personas Juridicas cit. (nota 39 supra), p. 458.

${ }^{137}$ Conforme o artigo 53 do Código Civil. 
categoria possuir vantagens especiais, como permitido pelo artigo 55 do Código Civil - e outros deles delegam essa tarefa para um regulamento geral ${ }^{138}$.

Normalmente as diferentes categorias subdividem os associados de acordo com determinados critérios, conferindo-lhes alguns privilégios. Uma das categorias pode abranger os associados fundadores ou mais antigos, outra pode reunir os associados que tiverem prestado serviços relevantes ou efetuado doações à associação e outra pode ainda reunir membros laureados, como reconhecimento pela representação oficial da entidade ou pelo elevado nível técnico que tenha alcançado. Existem ainda os associados denominados remidos, que integraram o quadro da entidade por um longo prazo.

Os estatutos prevêem as condições para receber determinadas vantagens e títulos de reconhecimento. Alguns deles são isentos de prestar contribuições pecuniárias à associação. Aqueles que o fazem pertencem à categoria dos associados patrimoniais, ativos ou efetivos.

Nem todas as categorias de associados possuem o direito de participar das assembleias, podendo votar e ser votados e propor a admissão de associados. Os direitos e deveres dos associados podem, assim, variar de acordo com as categorias instituídas, desde que tais vantagens estejam expressamente previstas no estatuto ou regulamento ${ }^{139}$.

Os estatutos contêm também as condições de admissão dos associados ou disposições que deleguem esta tarefa ao regulamento. O artigo 54 inciso II do Código Civil determina que o estatuto deve conter as condições de admissão dos associados, sob pena de nulidade. Contudo, a lei não estabeleceu que as entidades ou seus órgãos devessem justificar os casos de rejeição das propostas de admissão, o que nos parece conferir uma

\footnotetext{
${ }^{138}$ No Esporte Clube Pinheiros, por exemplo, são previstas as seguintes categorias de associados: beneméritos, honorário, remidos, contribuintes, veteranos, atletas beneméritos e atletas beneméritos contribuintes, sendo que o regulamento geral especifica o que se entende por cada uma delas. Na Associação dos antigos alunos da faculdade de direito da Universidade de São Paulo existem associados efetivos, mestres e beneméritos. O Instituto Cultural Brasil Itália Europa possui as seguintes categorias de associados: sócios fundadores, beneméritos e honoríficos, dirigentes, efetivos, colaboradores ou sustentadores e beneficiários. A WWF- Brasil possui associados ativos, honorários, presidente emérito, benfeitores e notáveis. No Sport Club Corinthians, as categoriais de associados são: titulados (divididos em fundadores, patronos e grandes beneméritos, beneméritos, atletas laureados, honorários, patrimoniais, benfeitores, remidos), contribuintes, militantes, de futebol. É prevista a possibilidade de criação da categoria de fiel torcedor, sempre sem direito a voto, dependente de regulamentação pela diretoria e pelo conselho diretivo.

${ }^{139}$ Ver artigo 55 do Código Civil.
} 
certa discricionariedade àqueles que as analisam, apesar das condições de admissão estarem previstas no estatuto ${ }^{140}$.

Em relação à exclusão dos associados, notamos que os estatutos costumam conter hipóteses detalhadas das punições aplicáveis a eles, disciplinando cuidadosamente as hipóteses de exclusão, como demanda a lei ${ }^{141}$.

As punições para infrações dos estatutos e regulamentos sociais variam usualmente - em ordem de gravidade - de advertências e suspensões a exclusões. Normalmente se prevê que deve ser assegurado ao associado o direito à ampla defesa e interposições de recursos. Para a exclusão é praxe estabelecer o órgão ao qual compete a aplicação desta penalidade, prevendo-se a necessidade de justa causa e de procedimento prévio que assegure o direito de defesa e de recurso ${ }^{142} 143$.

Os estatutos prevêem os direitos e deveres dos associados - que, como mencionamos, podem variar de acordo com as diversas categorias - e que a qualidade de associado é intransmissível ${ }^{144}$.

As entidades possuem órgãos deliberativos, executivos e de fiscalização. Outros órgãos podem ser previstos, como órgãos consultivos. A composição e a competência dos órgãos são previstas nos estatutos ${ }^{145}$.

\footnotetext{
${ }^{140}$ No Esporte Clube Pinheiros, por exemplo, o estatuto delega ao regulamento geral fixar as condições de admissão dos associados. Contudo, os motivos de rejeição da proposta de admissão não serão comunicados aos associados.

${ }^{141}$ Ver artigo 54, inciso II do Código Civil.

${ }^{142}$ Conforme previsto no artigo 57 do Código Civil.

${ }^{143}$ No Esporte Clube Pinheiros são previstas as seguintes penalidades para o associado que infringir as disposições do estatuto social, do regulamento geral, regimento e resoluções: advertência por escrito, suspensão, eliminação e exclusão. A aplicação da sanção de exclusão compete privativamente e mediante representação da diretoria ao conselho deliberativo. Será passível de exclusão o associado que: reincidir em infrações que, por sua natureza e reiterações, o tornem inidôneo para permanecer no clube, a juízo do conselho deliberativo; for condenado por sentença passada em julgado pela prática de delito infamante; atentar contra a moralidade social e desportiva ou contra superiores interesses do clube; deixar, após notificação, de indenizar o clube por danos, devidamente apurados, que ele ou os membros de sua família causarem e que tiver em depósito, preparar, transportar, trouxer consigo adquirir, vender, guardar, fornecer ainda que gratuitamente, ministrar ou entregar, de qualquer forma, a consumo, substância entorpecente ou que determine dependência física ou psíquica. Na WWF-Brasil o associado será excluído se desejar se desligar da associação ou por justa causa, independentemente de sua categoria, nos casos previstos no estatuto. A exclusão do associado deverá ser aprovada pela maioria dos presentes na reunião do conselho diretor convocada para esse fim. Dessa decisão, caberá recurso à assembleia. No Sport Club Corinthians os associados, que possuem o direito de recorrer das penalidades que lhes forem aplicadas, são passíveis das seguintes penalidades: advertência escrita, suspensão e desligamento, sendo assegurado em qualquer hipótese o direito de defesa. A aplicação das penalidades é disciplinada pelo estatuto, devendo, antes de sua aplicação, ser assegurado ao associado a real possibilidade de exercício da ampla defesa perante a comissão de ética e disciplina, a seu juízo por via escrita e/ou oral, pessoalmente ou por procurador regularmente constituído. Da decisão caberá recurso.

${ }^{144}$ Ver artigo 56 do Código Civil. Não encontramos, nas entidades analisadas, nenhum estatuto que estabelecesse que a condição de associado pudesse ser transmissível.
} 
De acordo com o artigo 59 do Código Civil, os estatutos estabelecem que compete privativamente à assembleia geral a destituição dos administradores e alteração do estatuto, em assembleia especialmente convocada para esse fim. Alguns prevêem a necessidade de quorum qualificado para a tomada de tais deliberações ${ }^{146}$.

Em relação à dissolução das associações, os estatutos dispõem que a deliberação caberá à assembleia geral, com quorum qualificado. Alguns prevêem os motivos que podem ensejar a dissolução, bem como a quem caberá o patrimônio da entidade a ser dissolvida ou como isso deverá ser decidido. Normalmente os bens remanescentes são destinados a entidades com fins análogos ao da associação dissolvida, conforme estabelecido no artigo 61 do Código Civil ${ }^{147}$.

Interessante é a disposição encontrada em um dos estatutos analisados, permitindo o exercício de atividade empresária pela entidade, desde que seja para atingir a sua finalidade, podendo constituir sociedade empresária para explorar as atividades

145 O Esporte Clube Pinheiros possui órgãos deliberativos (assembleia e conselho deliberativo), executivos (diretoria), de fiscalização (conselho fiscal) e consultivos (comissões permanentes). A Associação dos exalunos da faculdade de direito da Universidade de São Paulo possui: assembleia de associados, diretoria executiva, conselho consultivo e conselho fiscal. O Instituto Cultural Brasil Itália Europa possui assembleia geral, conselho diretor, secretaria executiva e conselho fiscal. Os órgãos da WWF-Brasil são assembleia, conselho diretor, conselho fiscal e diretoria. No Sport Club Corinthians existem a assembleia geral, o conselho deliberativo, conselho de orientação, conselho fiscal e diretoria. Apesar dos nomes dos órgãos variarem um pouco entre as entidades, as funções exercidas são sempre semelhantes, havendo um órgão hierarquicamente superior, que é a assembleia de associados, um órgão com funções executivas, como as diretorias, um órgão com funções de fiscalização, como o conselho físcal e, querendo, outros órgãos com funções consultivas ou de resolução de controvérsias internas entre os associados.

${ }^{146}$ No caso do Esporte Clube Pinheiros, na Associação dos antigos alunos da Universidade de São Paulo e no Instituto Cultural Brasil Itália Europa é previsto o quorum de 2/3 dos associados. Na Academia Brasileira de Letras, o voto expresso da maioria absoluta dos membros efetivos.

147 No Esporte Clube Pinheiros somente a assembleia geral poderá dissolver o clube por motivo de insuperável dificuldade no preenchimento de seus objetivos, mediante a decisão de pelo menos $2 / 3$ dos associados com direito a voto. $\mathrm{O}$ acervo social será destinado a uma ou mais associações beneficentes, a juízo do conselho deliberativo. No caso de extinção da Academia Brasileira de Letras, liquidado o passivo, o saldo remanescente reverterá em favor da União, se antes não se resolver seja transferido a algum estabelecimento público ou a alguma associação nacional que tenha fins idênticos ou análogos aos seus. Ocorrendo a extinção da Associação dos ex-alunos da faculdade de direito da Universidade de São Paulo, por impossibilidade de realização dos seus objetivos e finalidades, o seu patrimônio se reverterá a outra entidade sem fins econômicos e legalmente constituída, a ser indicada pela assembleia de associados. O Instituto Cultural Brasil Europa poderá ser dissolvido apenas nos casos previstos em lei ou por decisão da assembleia geral, expressa pela maioria de $2 / 3$ dos sócios com direito a voto, sendo seus bens patrimoniais destinados a instituições similares, neste caso cabendo ao secretário executivo ou seu substituto ser o liquidante nato da associação. A WWF-Brasil somente poderá ser dissolvida em assembleia especialmente convocada para esse fim, com o quorum de $2 / 3$ dos associados, e se for constatada a impossibilidade de sua sobrevivência ou desvirtuamento de suas finalidades. O remanescente de seu patrimônio líquido será destinado a entidade com fins não econômicos, por deliberação de seus associados, que preferencialmente tenha o mesmo objetivo da associação, a ser pertinentemente designada por deliberação dos associados. Já no Sport Club Corinthians a dissolução também cabe à assembleia geral extraordinária, e seus bens passarão à Santa Casa de Misericórdia da Capital - SP. 
próprias ou participar do capital social de qualquer outra associação, fundação ou sociedade $^{148}$.

I.5. Os associados. Direitos e deveres. Igualdade e possibilidade de instituição de categorias diversas. Admissão. Existência de direito subjetivo à admissão. Transmissão da qualidade de associado. Inexistência de vínculos entre os associados

Os direitos e os deveres dos associados devem estar previstos no ato constitutivo ou no estatuto.

A princípio, os membros devem ter iguais direitos, mas o estatuto poderá instituir categorias com vantagens especiais ou restrições ${ }^{149} 150$.

F. C. PONTES DE MiRANDA explica que da relação jurídica de membridade entre o associado e a entidade - surgem direitos, pretensões, deveres e obrigações, existindo alguns direitos e obrigações específicos ${ }^{151}$.

\footnotetext{
${ }^{148} \mathrm{O}$ estatuto do Sport Club Corinthians prevê que para atingir a sua finalidade a entidade poderá constituir sociedade empresária para explorar as atividades próprias, diretamente ou em parceria, administrar as atividades relacionadas ao futebol não profissional e/ou profissional, vedada a utilização dos bens patrimoniais do Corinthians para integralizar parcela do capital social ou oferecê-los em garantia, salvo com a concordância de pelo menos $2 / 3$ da assembleia geral, especialmente convocada para essa finalidade. Poderá também para atingir as suas finalidades participar do capital social de qualquer outra associação, fundação ou sociedade, integralizando o capital social com valores, bens ou com a cessão temporária do direito de uso de bens ou direitos integrantes do seu ativo, inclusive os recebidos temporária ou definitivamente por convênios ou outras formas de uso autorizado.

${ }^{149}$ Ver artigo 55 do Código Civil de 2002.

${ }^{150}$ F. U. COELHo, Curso de Direito Civil cit. (nota 10 supra), p. 251, esclarece, acerca dos direitos e deveres dos associados, que: "Os direitos e deveres dos associados estão definidos no estatuto. Este pode reservar para uma ou mais categorias de associados certas vantagens especiais. É comum, por exemplo, nos estatutos dos clubes, encontrar a classificação dos associados em fundadores, efetivos, honorários, remidos, etc. Na verdade a cada categoria corresponde um conjunto de vantagens (dispensa de pagamento da contribuição associativa ou assento permanente no Conselho Diretor) ou de restrições (inexistência de direito de voto nas assembleias), especificadas aquelas e estas nos atos constitutivos."

${ }^{151}$ Ver Tratado de Direito Privado cit. (nota 4 supra), pp. 393-394. "Direitos específicos são principalmente: a) o direito de tomar parte em assembleias; b) o direito de votar; c) o de eleição ativo e passivo; d) o direito de pedir convocações (quase sempre dependente do número mínimo de titulares, em ato coletivo); e) os direitos de uso dos bens destinados, e comum, pro diviso ou pro indiviso , aos associados e sócios (...) g) o direito à quota de liquidação, se extinta a associação (...). Os direitos "a" a "d" são direitos organizativos, direitos de participação social; os de "e" a "g", direitos de valor. As obrigações específicas são as de pagar quotas e as de assumir cargos; ou de comparecer às assembleias e reuniões de comemoração, ou outras, de frequiência, se é previsto no ato constitutivo, ou, por outra maneira, se o ato constitutivo o prevê. Os direitos dependem do ato constitutivo, ou, se esse o promete, de deliberação de assembleia. Os direitos específicos gerais (=de todos os membros) são suscetíveis de alteração ou supressão, ex nunc, por deliberação da assembleia, ou, se constam dos estatutos, por deliberação da assembleia para a mudança dos estatutos; desde que a alteração ou supressão também seja geral.”
} 
$\mathrm{O}$ autor denomina os direitos que conferem vantagens especiais a um associado, alguns deles ou a uma determinada classe de específicos preferentes (Sonderrechte). Apesar de terem nascido da desigualdade, não constituem infração dos princípios $^{152}$.

$\mathrm{O}$ ato constitutivo e o estatuto devem, assim, estabelecer os direitos e deveres de cada categoria de associados. O direito de voto, por exemplo, pode ser concedido ou negado ${ }^{153}$.

Os membros das associações possuem direito à egressão, ou seja, de se retirar da pessoa jurídica, podendo o estatuto estabelecer exceções a este procedimento. Pode ser prevista, ainda, a perda da qualidade de associado em determinadas circunstâncias $^{154}$.

Uma das obrigações dos associados é a contribuição, que pode tomar formas diversas, como pecuniária, prestação de serviços, participação na gestão e outros. As obrigações, para F. C. PONTES DE MIRANDA, são classificadas em sociais gerais ou específicas, comuns a todos os membros, e sociais ou específicas excepcionais, conferidas apenas a alguns deles ${ }^{155}$.

Dentre os deveres dos associados, é obrigatório a quem usufrui das utilidades da associação contribuir na proporção indicada na convenção ${ }^{156}$.

Os associados devem ser tratados com igualdade, inclusive nas assembleias, na diretoria e nos demais órgãos da entidade. Nenhum membro pode ser tratado

\footnotetext{
${ }^{152}$ Ver F. C. PonTES De MiRAnda, Tratado de Direito Privado cit. (nota 4 supra), p. 395. Para eliminar ou diminuir tais direitos, é necessário o assentimento dos seus titulares.

${ }^{153}$ Ver W. DE B ARRos MonTEIRO, Curso de Direito Civil cit. (nota 42 supra), p. 153.

${ }^{154}$ Ver F. C. PONTES DE MIRANDA, Tratado de Direito Privado cit. (nota 4 supra), p. 402, acerca da retirada dos membros e seus efeitos: "Com a retirada, extinguem-se os direitos organizativos". A retirada pode se dar por renúncia, que "é declaração unilateral de vontade, dirigida ao órgão que o ato constitutivo haja indicado". Sobre as restrições que podem ser colocadas à renúncia, esclarece o autor: "As restrições temporais que podem ser feitas à renúncia são a do ano financeiro, ou social, e o prazo de denúncia, dito, vulgarmente, prazo de aviso prévio. As outras restrições são ilícitas, porque ofenderiam o princípio da egressibilidade. Também é ilícita a restrição de só se poder renunciar havendo razão para isso: seria transformar a renúncia em exercício do direito formativo extintivo, que emanaria do fato em que consiste a razão. (...) Toda eficácia da renúncia é ex nunc."

${ }^{155}$ Ver Tratado de Direito Privado cit. (nota 4 supra), p. 398: “A contribuição dos membros pode ser patrimonial, de serviços, de função de órgão social, ou de alguma atividade ou omissão, que corresponda aos fins da pessoa jurídica." $\mathrm{O}$ ato constitutivo contém penalidades para o seu descumprimento. (...) Como exemplo de obrigações sociais ou específicas excepcionais o autor cita as que têm, estatutariamente, os sócios novos, de prestarem serviços antes dos outros.

${ }^{156}$ TJSP, 6 a Câm. Dir. Priv., Apel.n. 0009040-47.2009.8.26.0048, Rel. Percival Nogueira, j. 14-7-2011.
} 
diferentemente, salvo se os demais assim quiserem e houver o assentimento do que será tratado desigualmente ${ }^{157}$.

A princípio, em razão do aspecto eminentemente pessoal das associações, a qualidade do associado é intransmissível, seja por cessão de quotas, seja em razão do seu falecimento, salvo se o estatuto dispuser o contrário. A transferência de quota ou fração ideal do patrimônio da associação não importará, de "per si”, portanto, na atribuição da qualidade de associado ao adquirente ou herdeiro, salvo disposição diversa do estatuto ${ }^{158}$ 159

A qualidade de membro - que é relação jurídica para F. C. PONTES DE MIRANDA -, não se transfere, nem se transmite. Havendo disposição estatutária permitindo a transmissão, ocorrerá a investidura de novo membro, com sucessão nos direitos e deveres que possam ser transmitidos, podendo o estatuto criar pressupostos materiais e formais à nova investidura ${ }^{160}$.

Percebemos, assim, que é dada uma certa discricionariedade aos membros da associação para disciplinar, no estatuto, as condições de admissão dos associados, a existência de categorias com vantagens especiais, a possibilidade de transferência da qualidade de associado, bem como a aceitação do adquirente de quota ou herdeiro, desde que preencha determinadas condições, estabelecidas no estatuto ${ }^{161}$.

Contudo, esses critérios de admissão, demissão e exclusão dos associados devem ser objetivos e claros, para evitar violações ao princípio da igualdade ou discriminações aos potenciais futuros membros da associação, bem com aos membros demitidos ou excluídos.

\footnotetext{
${ }^{157}$ Ver F. C. PONTES De MIRANDA, Tratado de Direito Privado cit. (nota 4 supra), p. 394. As deliberações que infringem tal princípio da igualdade do tratamento social serão inválidas, por serem ilícitas.

${ }^{158}$ Ver artigo 56 caput e parágrafo único do Código Civil de 2002.

${ }^{159}$ Ver F. C. PONTES DE MIRANDA, Tratado de Direito Privado cit. (nota 4 supra), p. 391: "O ser membro é intransmissível inter vivos e mortis causa; o que é criável, pelos estatutos, é o direito do herdeiro, ou do sucessor entre vivos, ser membro. Por outro lado não existe, em princípio, direito a ser admitido como sócio ou associado (direito formativo gerador); mas ato constitutivo pode estabelecê-lo a favor de determinadas pessoas."

${ }^{160}$ Ver Tratado de Direito Privado cit. (nota 4 supra), p. 399.

${ }^{161}$ Ver F. C. PONTES De MIRANDA, Tratado de Direito Privado cit. (nota 4 supra), explicando que, para o ingresso de novos membros na associação, é necessária uma declaração de vontade, que é negócio jurídico: "A declaração de vontade para ingresso é negócio jurídico, que, à semelhança das ofertas contratuais, se vai ligar à aceitação (admissão do membro) para formar o negócio jurídico bilateral do ingresso de membro novo. Não se trata de contrato; trata-se de negócio jurídico bilateral que não é contrato. (...) A admissão de novos membros é declaração de vontade da associação (...) compete à Assembleia, se outro órgão não foi indicado pelo ato constitutivo. (...) o ato constitutivo pode estabelecer quais os pressupostos subjetivos e objetivos dos ingressandos e tornar o negócio jurídico de ingresso aceitação à declaração de vontade da pessoa jurídica."
} 
F. GALGANO explica que os direitos e obrigações dos associados encontram a própria fonte necessária no contrato de associação. Existem, contudo, alguns direitos que são inerentes ao conteúdo legal do contrato de associação e não necessitam de previsão estatutária explícita, como participar da assembleia, votar, impugnar as deliberações da assembleia e exercer o recesso. Os membros não podem sustentar direitos ou serem compelidos a cumprir obrigações que não sejam previstas no contrato de associação. $\mathrm{O}$ contrato pode remeter aos órgãos da entidade a determinação periódica das formas de exercício dos direitos ou as modalidades de cumprimento das obrigações por ele previstas $^{162}$.

A obrigação de contribuir pode consistir, para os associados ou para uma categoria especifica deles, no pagamento de uma soma em dinheiro, na transferência de uma propriedade ou na fruição de bens móveis ou imóveis. A contribuição pode consistir, ainda, em qualificações pessoais dos membros. À contribuição pode ser acrescentada, para todos ou para uma determinada categoria de associados, determinadas prestações pessoais. Por fim, pode haver dispensa de prestar qualquer contribuição, patrimonial ou pessoal ${ }^{163}$.

F. GALGANO sustenta que pode parecer difícil, no campo do direito privado, justificar a presença do princípio da igualdade entre os associados, pois deveria ser possível, com a autonomia contratual, sustentar o acordo dos particulares para dar tratamento desigual a eles, de acordo com a sua posição. Permite-se a presença de cláusula no estatuto que atribua a determinados associados, ou a uma categoria deles, algumas vantagens ou desvantagens. Para o autor, não se trata de aplicação do princípio constitucional da igualdade, sob pena de se destruir a autonomia privada, e sim a exigência é inerente às características próprias do tipo contratual, valendo, nas relações entre os

\footnotetext{
${ }^{162}$ Persone giuridiche cit. (nota 57 supra), p. 269.

163 Ver F. Galgano, Persone giuridiche cit. (nota 57 supra), pp. 269-271, explicando acerca das contribuições dos associados que os sócios ordinários normalmente arcam com uma taxa inicial de admissão e com contribuições anuais em dinheiro. $\mathrm{O}$ aumento do montante da contribuição pode ser deliberado para o futuro, mas não pode ser admitido com força retroativa para o passado, garantindo-se ao sócio o direito de recesso se discordar da deliberação tomada. Não se pode impor aos associados que contribuam à extinção do passivo com o depósito de outros valores, além das contribuições, proporcionais aos débitos da associação, porque os associados possuem o benefício da responsabilidade limitada, que limita a responsabilidade externa deles, ou seja, em relação aos credores. Isso não impede que o grupo imponha aos próprios membros a prestação de outras contribuições, com o objetivo de extinguir o passivo. Tal direito se baseia na relação interna entre a corporação e os seus membros e é independente da relação de débito da associação com os seus credores. Assim, o ato constitutivo da associação deve determinar se os associados serão obrigados a efetuar, a pedido dos órgãos corporativos, contribuições suplementares.
} 
associados, somente dentro dos limites nos quais se possa dizer elemento intrínseco do conteúdo legal deste contrato ${ }^{164}$.

Para o autor não deveriam ser admitidas, nas associações, cláusulas que impedissem uma determinada categoria de associados de votar, que estabeleçam um voto múltiplo ou um número de votos proporcional à contribuição. Sustenta que as desigualdades entre os associados são vedadas, sendo nulas as cláusulas estatutárias nesse sentido. O mesmo vale em relação à fruição dos serviços prestados pela entidade. Por outro lado, qualquer tipo de desigualdade pode ser admitida em relação às contribuições, não devendo o objeto da contribuição ou a sua forma de execução ser iguais para todos ${ }^{165}$.

O contrato de associação possui uma estrutura pessoal aberta, sendo o vínculo associativo aberto a todos aqueles que possuírem os requisitos previstos pelo ato constitutivo e fechado para aqueles que não os possuírem. Há uma vontade dos contratantes que a sucessiva adesão seja consentida a quem se demonstrar portador de interesses homogêneos em relação àqueles que determinaram a constituição da relação associativa, e seja fechada àqueles com interesses estranhos. Trata-se do denominado princípio da "porta aberta", que não protege, contudo, o interesse de terceiros ao ingresso na entidade e muito menos atribuem a eles um direito de admissão. Protege, ao contrário, o interesse contratual dos associados de ampliar a base pessoal da associação ${ }^{166}$.

A adesão a uma associação já constituída é, por parte da associação ou do aspirante a membro, um ato de autonomia contratual. É necessário o acordo entre as partes preexistentes da relação e o novo contraente. Os órgãos internos da associação devem obedecer aos critérios previstos no estatuto para admissão ou rejeição do novo membro, sob pena de aplicação das sanções previstas no estatuto para o caso de violação dos seus deveres $^{167}$.

De acordo com M. BASILE a composição de um ente pode mudar no decorrer do tempo sem que isso altere a sua identidade ou determine a descontinuidade na

\footnotetext{
${ }^{164}$ Persone giuridiche cit. (nota 57 supra), pp. 271-273. O autor explica que as cláusulas que introduzem desigualdades entre os associados são freqüentes. Os estatutos de muitas associações estabelecem diversas categorias de associados: beneméritos, vitalícios, ordinários, e outros, recebendo os que pertencem a cada categoria um tratamento diferenciado, manifestando-se as desigualdades seja em relação aos chamados direitos administrativos dos associados, seja em relação ao direito de fruir dos serviços da associação, ou seja, por fim, em relação à contribuição.

165 Persone giuridiche cit. (nota 57 supra), pp. 273-276.

${ }^{166}$ Ver F. GALGANO, Persone giuridiche cit. (nota 57 supra), pp 276-278. O autor entende que seria nula uma cláusula que vedasse novas adesões ou que as colocasse no arbítrio dos administradores.

${ }^{167}$ Ver F. Galgano, Persone giuridiche cit. (nota 57 supra), p. 278.
} 
sua duração. As associações podem admitir novos participantes, verificar casos de sucessão na qualidade de membro ou ainda podem ficar sem associados. Em regra, a autonomia coletiva estabelece os requisitos para a admissão de novos membros da entidade, podendo decidir pela não admissão de outros integrantes, pois a associação não deve, então, necessariamente, ser aberta a terceiros. Contudo, o ato constitutivo é normalmente um negócio aberto ${ }^{168}$.

A sucessão da qualidade de associado é subordinada a uma previsão no ato constitutivo ou estatuto. $\mathrm{Na}$ sua omissão, nenhum princípio atribui a terceiros o direito de ser admitido como membro ${ }^{169}$.

A legitimidade dos limites ao ingresso de novos associados foi questionada, porque incide na liberdade do grupo de consentir novos ingressos, estabelecer os requisitos e avaliar a concreta subsistência, e de outro lado na liberdade dos terceiros de decidir se se inscrevem ou não a um grupo, ou pelo menos de escolher a que grupo aderir. A jurisprudência italiana entendeu que nem todos os limites são ilegítimos, podendo a liberdade "negativa" de associação ser restrita mais do que seria possível para a liberdade "positiva",

Parece não haver um direito subjetivo de admissão a quem possuir os requisitos previstos pelo legislador ou pela autonomia coletiva dos associados. Não se pode falar em uma pretensão toda a vez que os órgãos do ente sejam chamados a deliberar sobre o requerimento de adesão, com discricionariedade de juízo. Não existe pretensão, portanto, se o requerimento pode ser rejeitado por uma apreciação não vinculada a parâmetros rígidos. $\mathrm{O}$ direito à admissão existiria somente se e quando não houvesse discricionariedade na análise do requerimento do terceiro, mas não existem disposições que gerem tais efeitos no direito italiano ${ }^{171}$.

\footnotetext{
${ }^{168}$ Ver M. BASILE, Persone giuridiche cit. (nota 54 supra), pp. 115-116.

169 Ver M. BASILE, Persone giuridiche cit. (nota 54 supra), pp. 116-117. O autor esclarece que esta regra permite ao grupo conceder aos seus órgãos a possibilidade de avaliar caso a caso a adequação, do ponto de vista dos fins e programas comuns, de quem queira suceder. $\mathrm{O}$ seu alcance fica circunscrito a outras normas introduzidas a garantir, ou promover, o ingresso de determinados sujeitos, a benefício deles ou do grupo, em razão da realização de exigências de ordem geral. Às vezes se estabelece a automática participação ao grupo a quem manifeste uma vontade nesse sentido, ou a quem possua determinados requisitos; outras vezes esses são obrigados a se inscrever e o grupo deve admiti-los. Em alguns casos a admissão não é devida, e representa para os terceiros um ônus requerê-la, enquanto for condição para o exercício da parte deste de determinada atividade.

${ }^{170}$ Ver M. BASILE, Persone giuridiche cit. (nota 54 supra), pp. 116-117.

${ }^{171}$ Ver M. BASILE, Persone giuridiche cit. (nota 54 supra), pp. 119-120. O autor entende que o ingresso no grupo comporta a investidura do terceiro na posição jurídica predisposta para os seus membros. Muitas vezes os estatutos possuem cláusulas restritivas de direitos individuais: por exemplo, estabelecem a renovação
} 
Os tribunais têm concedido liberdade às associações para disciplinar as condições de admissão de seus associados. Apenas em alguns casos o associado pode recorrer ao Judiciário, parecendo não ser aceito um direito subjetivo à admissão. Nesse sentido, já se decidiu que um determinado clube que não poderia ser compelido a admitir um demandante como associado, por inexistir prerrogativa de ser admitido como tal, desrespeitando a vontade da pessoa jurídica. Afastou-se, ainda, o pedido de indenização por danos morais ${ }^{172}$.

No mesmo sentido, manteve-se a negativa de ingresso de profissional em associação de classe profissional e se afastou a indenização por danos morais em caso de simples aborrecimento, não configurada má-fé, desde que a recusa tenha sido apoiada no estatuto e não discriminatória ${ }^{173}$.

O associado pode submeter ao Judiciário um conflito na interpretação de normas estatutárias dos entes associativos, não ocorrendo, no caso, violação da liberdade de associação. A entidade pode impor condições para admissão de seus associados, desde que não fira vedação constitucional ou legal, não cabendo ao Judiciário alterar as disposições estatutárias livremente estabelecidas, sob pena de violar a liberdade das associações $^{174}$. Portanto, os associados podem dispor, da forma que mais conveniente lhes parecer, quanto ao acesso de novos integrantes ao seu quadro social. Não é possível, entretanto, estabelecer discriminação que a lei não admite ${ }^{175}$.

Entende-se, porém, que se o associado adquiriu quota de forma regular, atendendo aos requisitos contidos no estatuto para ingresso nos quadros de associados, não poderá ser impedido de gozar dos direitos inerentes ao seu título, mesmo com a inércia do órgão responsável em apreciar o pedido de aspirante a sócio de clube ${ }^{176}$.

O direito francês também permite a criação de diferentes categorias de membros nas associações. Existem, assim, os membros fundadores, que são aqueles que estão na origem do projeto associativo; os membros honorários, que designam as pessoas que tenham, por exemplo, prestado serviços importantes; os membros aderentes, que

tácita da relação associativa, limitando a faculdade de recesso ou prescrevem a resolução das disputas internas através de formas de justiça endo-associativas. Muitas vezes os novos associados questionam judicialmente a submissão a essas cláusulas. Os tribunais italianos têm decidido que essas cláusulas valem também para os novos associados, mesmo se não as aprovaram de forma específica.

${ }^{172}$ TJSP, $1^{\text {a }}$ Câm. Dir. Priv., Apel. n. 9219922-46.2007.8.26.0000, rel. Luiz Antônio de Godoy, j. 19-7-2011.

${ }^{173}$ TJMG, $18^{\text {a }}$ Câm. Cível, Apel. n. 1002403055956-1-001, rel. Elpídio Donizetti, j. 22-7-2008.

${ }^{174}$ TJRJ, $3^{\text {a }}$ Câm. Cível, Apel. n. 2009.001.17050, rel. Fernando Foch, j. 4-8-2009.

${ }^{175}$ STJ, $3^{\text {a }}$ Turma, R. Esp. 93634-MG, rel. Min. Eduardo Ribeiro, j. 18-10-1999.

${ }^{176}$ TJMG, $18^{\mathrm{a}}$ Câm. Cível, Ag. n. 1002407491363-3-001, rel. Fábio Maia Viani, j. 2-10-2007. 
contribuem anualmente e os membros de direito, que são membros de acordo com uma qualidade própria deles ${ }^{177}$.

Para adquirir a qualidade de membro, deve haver um consentimento recíproco e o candidato deve ter capacidade suficiente e prestar a sua contribuição, que poderá ser pecuniária ou sob forma de determinada atividade, bem como possuir uma finalidade que não seja distribuição de $\operatorname{lucros}^{178}$.

A perda da qualidade de membro pode se dar com a sua demissão; com o fim da duração da adesão; por exclusão; por morte ou pelo desaparecimento de uma condição exigida pelos estatutos ${ }^{179}$.

Y. GUYON explica que existem diversas obrigações dos associados em relação à sociedade, aos outros associados e aos terceiros, o que podemos aplicar por analogia para as associações. Sendo assim, o sócio ou associado possui uma obrigação geral de boa-fé em relação à sociedade ou associação e aos seus cossócios ou coassociados. É um dever fiduciário, que parece ser uma manifestação de affectio societatis ${ }^{180}$.

Existem direitos próprios ou intangíveis dos associados, que possuem caráter contratual e que a maioria não pode subtrair, e direitos derivados, dos quais a coletividade de associados pode fixar o conteúdo. Contudo, muitos direitos são intangíveis na sua existência, mas relativos nas suas condições de exercício. A participação social pode, por exemplo, ser cedida, mas a sua cessão depende de um acordo dos outros $\operatorname{associados}^{181}$.

O associado possui o direito de não ser excluído da sociedade ou associação, tendo esse direito de fazer parte da entidade um fundamento contratual. A exclusão seria uma resolução do contrato que liga o associado à sociedade e supõe uma culpa. A exclusão é possível a título de sanção ou de regularização. Nesse caso, o associado é excluído para permitir a sobrevivência da sociedade ou associação ou mesmo o seu funcionamento normal $^{182}$.

\footnotetext{
${ }^{177}$ Ver P. DELAMARRE, Créer e faire vivre cit. (nota 37 supra), pp. 58-59

${ }^{178}$ Ver P. DELAMARRE, Créer e faire vivre cit. (nota 37 supra), pp. 59-61.

${ }^{179}$ Ver P. DELAMARRE, Créer e faire vivre cit. (nota 37 supra), pp. 64-67.

${ }^{180}$ Les Sociétés cit. (nota 126 supra), pp. 66-67.

${ }^{181}$ Ver Y. GUYON, Les Sociétés cit. (nota 126 supra), p. 78.

${ }^{182}$ Ver Y. GUYON, Les Sociétés cit. (nota 126 supra), pp. 79-83. O autor entende que essas causas são difíceis de se justificar com o direito das obrigações e parecem se referir a uma aplicação do affectio societatis, pois o interesse particular do associado é sacrificado em prol do interesse da sociedade ou associação.
} 
$\mathrm{O}$ associado tem o direito de não ser obrigado a permanecer na sociedade ou associação, caso a maioria lhe imponha novas obrigações. Uma modificação do estatuto não poderá aumentar os compromissos dos associados, salvo acordo unânime dos interessados ${ }^{183}$.

$\mathrm{O}$ associado possui um direito de informação, que no direito francês possui dois significados distintos: o direito de informação em sentido estrito, ou seja, o direito de receber comunicação de certos documentos e, por outro lado, o poder de investigação, que permite ter acesso a informações que não são enviadas pela própria sociedade ou associação $^{184}$.

No direito alemão, a expressão ‘condição de associado' designa o conjunto de relações jurídicas entre a associação e seus membros. Trata-se de relação com caráter personalíssimo: a condição de associado não é transferível inter vivos ou causa mortis. Os direitos derivados dela só podem ser exercidos, a princípio, pelo próprio associado ${ }^{185}$.

Como principais direitos, existem: o direito de participação nas atividades da associação, como os debates da assembleia e, sobretudo, o direito de voto e direitos patrimoniais, como a utilização das instalações da associação ${ }^{186}$.

A condição de associado também implica em obrigações, como o dever de lealdade em relação à associação e seus membros. A obrigação maior é o aporte da contribuição. A condição de associado não só implica numa relação jurídica do membro com a associação, como também constitui um direito subjetivo ou bem jurídico ${ }^{187}$.

O regime jurídico das associações é regido pelo princípio da igualdade de tratamento de seus membros. Para F. KÜBLER, não se trata de uma exigência do princípio constitucional da igualdade e não tem caráter imperativo, podendo a autonomia da vontade dispor em seus estatutos a concessão de direitos especiais ou privilégios a alguns dos associados. Se o estatuto não dispuser diversamente, os direitos e obrigações que afetam todos os sócios podem se modificar por acordo majoritário. O princípio da igualdade proíbe que se introduzam distinções em prejuízo de alguns de seus membros, embora possam ser concedidos privilégios a alguns sócios ou grupos deles ${ }^{188}$.

\footnotetext{
${ }^{183}$ Ver Y. GuYON, Les Sociétés cit. (nota 126 supra), pp. 83-84.

${ }^{184}$ Ver Y. GUYON, Les Sociétés cit. (nota 126 supra), pp. 91-93.

${ }^{185}$ Ver F. KÜBLER, Derecho cit. (nota 61 supra), p. 218.

${ }^{186}$ Ver F. KÜBLER, Derecho cit. (nota 61 supra), pp. 219-220.

${ }^{187}$ Ver F. KÜBLER, Derecho cit. (nota 61 supra), pp. 219-220.

${ }^{188}$ Derecho cit. (nota 61 supra), pp. 220-221.
} 
Para o autor, mais complicados são os casos em que se modificam as distinções entre os associados estabelecidas nos estatutos ou se modificam os estatutos para tratar desigualmente alguns grupos de associados. Deve se assegurar, a luz da finalidade da associação, que a distinção está justificada objetivamente, e, em caso negativo, deve-se entender que se trata de uma discriminação arbitrária e, portanto, ineficaz ${ }^{189}$.

A condição de associado é adquirida por participar na fundação da associação ou por ingresso posterior. A incorporação à associação constitui um contrato, que se aperfeiçoa no momento em que a associação aceita a solicitação ou declaração de adesão. Os estatutos podem prever a necessidade de cumprimento de alguns requisitos para a adesão e, salvo disposição em contrário, decidirá a assembleia de associados ${ }^{190}$.

A condição de associado termina pela sua retirada, podendo o estatuto limitá-la ao final do exercício contábil ou com um prazo de pré-aviso de no máximo dois anos. Contudo, segundo as regras gerais de direito privado, a retirada com justa causa deve ser permitida sem pré-aviso. A retirada supõe o término dos direitos e obrigações integrados na condição de associados ${ }^{191}$.

Concluímos que os associados possuem direitos e deveres, não constituindo violação ao princípio da igualdade a criação de diferentes categorias com determinadas vantagens. Os direitos e deveres devem ser previstos no estatuto da associação. O estatuto pode estabelecer, ainda, obrigações distintas para determinadas categoriais de associados. Alguns direitos são inerentes, contudo, ao conteúdo legal do contrato de associação, não necessitando de previsão. Não se permite, por exemplo, a modificação de direitos ou a introdução de distinções em prejuízo de alguns dos membros das associações, a não ser que haja concordância da categoria prejudicada.

A qualidade de membro é intransmissível, salvo disposição diversa do estatuto. A autonomia coletiva estabelece os requisitos para a admissão de novos membros da associação, que também devem estar contidos no estatuto. Não se pode falar, contudo, em direito subjetivo à admissão.

\footnotetext{
${ }^{189}$ Derecho cit. (nota 61 supra), p. 221.

${ }^{190}$ Ver F. KÜBLER, Derecho cit. (nota 61 supra), pp. 221-222.

${ }^{191}$ Ver F. KÜBLER, Derecho cit. (nota 61 supra), p. 222.
} 


\section{I.6. Organizações não governamentais - ONGs}

É importante, no presente estudo, dedicar um item às organizações não governamentais (ONGs), em razão do papel relevante que desempenham na atualidade.

Tais entidades fazem parte do chamado Terceiro Setor e normalmente assumem a forma de associações sem fins lucrativos ou fundações, que muitas vezes complementam o papel do Estado, que se mostra ineficiente em setores relevantes da sociedade.

No Brasil atuam em diversos setores, como educação, saúde, proteção a crianças, direitos humanos, e outros.

Portanto, num estudo dedicado às associações, cabe fazer uma breve análise acerca da importância das ONGs e das funções que têm exercido em diversos setores da sociedade.

Nos Estados Unidos, H. HANSMANN narra que as primeiras instituições sem fins lucrativos se organizaram no setor da saúde, como hospitais, abrangendo em seguida outros setores, como educação e artes. A principal característica dessas entidades é a limitação a que estão sujeitas, de não distribuir os ganhos residuais para os indivíduos que exercem o seu controle, como os seus diretores, administradores e membros, o que não significa, contudo, que não possam auferir lucro. Essa restrição pode influenciar no seu desempenho ${ }^{192}$.

As entidades sem fins lucrativos têm desempenhado um papel relevante nas economias de outros países desenvolvidos, além dos Estados Unidos, posição que permanece crescente ${ }^{193}$.

A educação americana de alto nível é quase exclusivamente composta por entidades sem fins lucrativos. A educação é vista como um "bem associativo", que atrai os

\footnotetext{
${ }^{192}$ Economic theories of nonprofit organization, in W. POWELL, The nonprofit sector: a research handbook, Yale University Press, New Haven, 1987, disponível in www.ssrn.com [05.08.2011], pp. 27-42. O autor narra que, em razão dessa característica, as pesquisas empíricas mostram que essas entidades respondem de forma mais lenta aos aumentos da demanda do que as entidades com fins lucrativos. Uma possível explicação para isso seria que as organizações sem fins lucrativos possuem acesso limitado ao capital, dependendo muitas vezes de doações e subsídios. Outra razão seria que seus administradores não possuem incentivos para agir como verdadeiros empreendedores, em função da limitação de distribuição de lucros.

${ }^{193}$ H. HANSMANN, The ownership of enterprise, Harvard University, Cambridge, Massachusetts, 2000, pp. 1-

8. O autor constatou que a posição das entidades sem fins lucrativos é mais relevante nas economias avançadas do que nos países menos desenvolvidos.
} 
potenciais consumidores não em razão somente da qualidade e do preço dos produtos, e sim também pelas características pessoais daqueles que frequentam tais estabelecimentos. Isso acaba causando uma estratificação dos consumidores em razão das características pessoais dos demais ${ }^{194}$.

Portanto, nos Estados Unidos as entidades sem fins lucrativos dominam uma grande fatia do mercado, em especial no setor de recursos humanos. O fato de haver uma restrição à distribuição dos lucros pode reduzir o risco de um eventual comportamento oportunista por parte de sua administração, melhorando a eficiência da entidade ${ }^{195}$.

Contudo, quando ocorre uma redução na demanda, as entidades sem fins lucrativos demonstram dificuldades em reduzir os seus serviços ou ainda em se retirar de determinados setores. Uma provável explicação para esse comportamento seria que as restrições legais existentes dificultam à entidade retirar o capital investido nos propósitos aos quais se dedica para investi-lo em outras atividades. Além disso, os seus administradores possuem poucos incentivos para fazê-lo. Essas entidades podem agir, assim, como retentoras de capital. Em razão disso, a presença dos hospitais sem fins lucrativos ainda é marcante, mesmo com a expansão dos hospitais privados e sem que os dados empíricos tenham conseguido demonstrar que a qualidade dos serviços dos primeiros seja superior à dos segundos ${ }^{196}$.

\footnotetext{
${ }^{194}$ H. HANSMANN, Higher education as an associative good, Yale Law School, New Haven, working paper no. 99-15, set. 1999, disponível in www.ssrn.com [05.08.2011]. A referida tendência de estratificação entre as instituições educacionais é, para o autor, acentuada pelo fato delas serem sem fins lucrativos. Uma faculdade com fins lucrativos teria maiores incentivos para usar o preço, ao invés das qualidades pessoais dos seus estudantes, como atrativo para admissões. Assim, uma forte razão para a organização das instituições educacionais como entidades sem fins lucrativos seria o fato de a educação ser um bem associativo. Existem, contudo, outras razões, como o fato das universidades nos Estados Unidos receberem muitas doações, inclusive de ex-alunos.

${ }^{195} \mathrm{H}$. HANSMANN, The role of trust in nonprofit enterprise, in H. ANHEIER E A. BEN-NER, The study of nonprofit enterprise: theories and approaches, Kuwer Academic Publishers, 2003, pp. 115 a 122, disponível in www.law.yale.edu [05.08.2011]. Para o autor os problemas de assimetria nas informações entre as empresas e os consumidores não são suficientes para justificar a grande fatia do mercado das entidades sem fins lucrativos no setor de recursos humanos, embora minimizem alguns problemas de agenciamento. Outros fatores podem explicar melhor esse domínio, como a existência de políticas públicas que assegurem que a forma sem fins lucrativos deva ser utilizada somente onde obtiver vantagens sobre outras formas alternativas de organização dos meios de produção.

${ }^{196}$ H. HANSMANN, The changing roles of public, private, and nonprofit enterprise in education, health care, and other human services, in V. FucHS, Individual and social responsibility; child care, education, medical care, and long-term care in America, NBER, University of Chicago Press, pp. 245-276, disponível em $w w w . y a l e . e d u$ [05.08.2011]. Mesmo na ausência de subsídios implícitos ou explícitos, o autor narra que uma entidade sem fins lucrativos pode manter a sua capacidade e até crescer, em circunstâncias nas quais as entidades com fins lucrativos não estariam crescendo. As primeiras parecem ser mais suscetíveis que as segundas a operar com pouca ou muita capacidade.
} 
Concluindo, talvez os setores ainda dominados por entidades sem fins lucrativos possam começar a sofrer mudanças nos Estados Unidos ${ }^{197}$.

As entidades sem fins lucrativos têm desempenhado um importante papel na transição dos primeiros estágios de desenvolvimento para a organização de uma indústria de serviços. Trata-se de importante fonte de produção até que o financiamento da demanda seja adequadamente organizado e o serviço seja suficientemente regulado, permitindo às empresas com fins lucrativos ingressarem no mercado e atuarem como fornecedoras eficientes. Depois disso, a entidade sem fins lucrativos acaba perdendo a sua razão de ser, tendendo a reter capital ${ }^{198}$.

Podemos nos indagar se as organizações não governamentais estariam sujeitas às mesmas regras de governança que as sociedades com finalidades lucrativas, em especial em relação à sua gestão e à necessidade de prestação de contas.

Nas sociedades com fins lucrativos, a governança busca a eficiência e maximização dos lucros para os acionistas, enquanto que nas organizações sem fins lucrativos há uma preocupação maior em proteger todas as partes envolvidas, alinhando os diversos interesses. Existe, portanto, uma diferença de motivação para os administradores. Assim, a presença de diretores não executivos (independentes) na gestão - tida como uma das boas práticas de governança corporativa - pode levar esses administradores a perseguirem ações diferentes quando atuarem em organizações com e sem finalidades lucrativas $^{199}$.

\footnotetext{
${ }^{197}$ Cf. H. HANSMANN, The changing roles cit. (nota 196 supra), pp. 245-276. O autor enxerga uma evolução em direção ao predomínio das empresas com fins lucrativos. O domínio contínuo na educação das entidades sem fins lucrativos parece não possuir uma razão eficiente e, conseqüentemente, prevê que a educação comece a sofrer drásticas mudanças na estrutura e na propriedade das empresas, como ocorreu nas últimas décadas no setor da saúde nos Estados Unidos.

${ }^{198}$ H. HANSMAnN; D. Kessler; M. MCClellan, Ownership form and trapped capital in the hospital industry, in E. GLAESER, The governance of not for profit organizations, Yale Law School, research paper no. 266, maio 2002, disponível in www.ssrn.com [05.08.2011].

${ }^{199}$ M. LÜCKERATH-ROVERS; L. QUADRACKERS; A. DE BOS, Non executive directors in the profit and non profit sector: a different approach towards governance?, Management on line review, 2009, disponível in www.ssrn.com [05.08.2011]. Para os autores existem diferenças significativas entre os diretores independentes nas entidades com e sem fins lucrativos. Os resultados empíricos por eles pesquisados mostram que os diretores independentes nos dois tipos de entidades exercem atitudes diferentes em relação à supervisão, algumas em relação da natureza da organização. Parece também que o tipo de organização influencia o cumprimento das funções do diretor. O diretor da ONGs supervisiona menos os administradores do que nas companhias e contribui menos para a estratégia das entidades. A necessidade de independência do diretor parece ser maior nas ONGs.
} 
$\mathrm{O}$ fato de algumas ONGs receberem subsídios do governo gera um interesse deste a ser tutelado, o que pode resultar numa necessidade maior de prestação de contas e transparência do que é esperada nas companhias com fins lucrativos ${ }^{200}$.

Evidentemente, as isenções governamentais devem ser concedidas com cautela, sob pena de privilegiar entidades que não persigam funções sociais, devendo-se definir as entidades e as atividades merecedoras do titulo de organizações sem fins lucrativos e dos benefícios e incentivos.

$\mathrm{Na}$ Espanha, tem havido um crescimento do número de entidades sem fins lucrativos nas últimas décadas. Contudo, tal crescimento não tem sido acompanhado da implantação de técnicas de controle na administração, como ocorre nas entidades com fins lucrativos $^{201}$.

Essas entidades são, muitas vezes, administradas por voluntários não profissionalizados, o que traz dificuldades na qualidade da gestão, havendo, consequentemente, poucos procedimentos de melhoria de gestão e técnicas nesse sentido. A implantação de um plano de estratégia a longo prazo poderia auxiliar na administração dessas entidades, trazendo resultados positivos, o que acarretaria uma distribuição mais eficiente de recursos e um alcance mais satisfatório dos objetivos sociais. Uma sugestão de boa técnica a ser implantada seria a formalização e sofisticação dos instrumentos de contabilidade como sistemas de informação para o controle da administração ${ }^{202}$.

Na União Europeia as companhias do terceiro setor são fontes importantes de empreendedorismo e têm gerado empregos em muitas áreas, nas quais as empresas com fins lucrativos nem sempre são viáveis. Os órgãos europeus estão procurando promover o crescimento dessas entidades através de programas de financiamento para treinamento e profissionalização. Contudo, a Comissão Europeia tem evitado editar regras específicas para as informações econômicas e financeiras aplicáveis para todas as partes da economia

\footnotetext{
${ }^{200}$ M. LÜCKERATH-ROVERS; L. QUADRACKERS; A. DE BOS, Non executive directors cit. (nota 199 supra). Os autores sugerem que a criação de um código de governança para as entidades sem fins lucrativos seja guiada pelos mais importantes códigos do setor privado. Contudo, parece ser difícil criar um código que abranja todas as entidades sem fins lucrativos, em razão da sua diversidade e da multiplicidade de partes interessadas. 201 P. SOldEVILA; E. OlIVERAS, Management control in non-profit organizations: the case of the associations of economists in Spain, UPF Economics and Business working papaer n. 583, 2002, disponível in www.ssrn.com [05.08.2011]. As autoras explicam que as pesquisas empíricas são raras na área, mas os resultados indicam que as ferramentas de controle da administração são utilizadas excepcionalmente nas organizações sem fins lucrativos, muitas vezes apenas preenchendo os requisitos legais mínimos.

${ }^{202}$ P. SOLDEVILA; E. OlIVERAS, Management control cit. (nota 201 supra). Para as autoras a implantação de instrumentos contábeis mais sofisticados melhoraria a qualidade dos serviços oferecidos e poderia aumentar o número de associados - minimizando-se a tendência recente de diminuição do número de associados nessas entidades na Espanha-, bem como aumentaria o nível de eficiência e efetividade.
} 
social, embora existam algumas diretivas para as entidades sem fins lucrativos que exerçam atividade empresária que podem ser referidas de forma indireta ${ }^{203}$.

Portanto, podemos concluir que a implantação de boas técnicas de governança seria benéfica para as organizações não governamentais e para o alcance dos fins por elas perseguidos. Contudo, a criação e estabelecimento dessas práticas parecem ser mais complexos do que têm sido nas companhias com fins lucrativos, pois as entidades são diversas entre si e agregam uma pluralidade de partes interessadas que devem ser tuteladas.

No Brasil havia uma lacuna legislativa a respeito das associações, utilizando-se os termos associações e sociedades civis como sinônimos, embora a doutrina procurasse uma diferenciação entre eles, muitas vezes importando modelos de direito comparado.

As principais legislações sobre o Terceiro Setor são as Leis 9.637/98 (organizações sociais) e 9.790/99 (organizações da sociedade civil de interesse público). As associações sem fins econômicos foram tipificadas com a Lei 11.127/05, que alterou a redação original do Código Civil de 2002 no que diz respeito a essas entidades. Contudo, enquanto o Código Civil disciplinou um modelo de associação sob um forte controle e intervenção estatal, a legislação do Terceiro Setor procura incentivar a tomada de espaços e responsabilidades pelas organizações civis, que antes eram de competência do Estado ${ }^{204}$.

No Terceiro Setor se situam organizações privadas com adjetivos públicos, que ocupam, pelo menos em tese, uma posição intermediária, entre o Estado (Primeiro Setor) e o mercado (Segundo Setor), ou seja, essas entidades podem prestar serviços de interesse social sem as limitações do Estado e sem se preocupar com as ambições do mercado $^{205}$.

\footnotetext{
${ }^{203} \mathrm{C}$. TAVAGLINI, Improving NPO's accountability in the enlarged EU: towards a common framework for financial reporting in European NPOs, Università di Bologna, 2008, disponível in www.ssrn.com [05.08.2011]. O autor defende ser necessária a preparação de um modelo comum de contabilidade para todas as organizações sem fins lucrativos da União Européia, pois o panorama social é muito heterogêneo, não só nos tipos de companhias e setores de operação, mas também na forma de relacionamento com a sociedade civil, e especialmente nas praticas de contabilidade.

${ }^{204}$ R.X. LEONARDO, A reforma do direito das associações sem fins econômicos pela Lei 11.127 de 2005 e o Terceiro Setor, in Revista de Direito do Terceiro Setor, ano1, n.1, jan/jul 2007, pp. 39 a 52. Para o autor, inexiste uma correspondência estrita entre o modelo traçado pelo direito privado para as associações sem fins econômicos e o chamado marco legal do Terceiro Setor.

${ }^{205}$ J. E. S. PAES, Fundações, Associações e Entidades cit. (nota 32 supra), pp. 129-256. Para o autor o Terceiro Setor é mobilizador de um grande volume de recursos humanos e materiais para impulsionar iniciativas voltadas para o desenvolvimento social, setor no qual se inserem as sociedades civis sem fins lucrativos, as associações civis e as fundações de direito privado, todas entidades de interesse social. Lembramos que o termo sociedade civil não nos parece mais adequado.
} 
Quando nos referimos ao Terceiro Setor, é comum pensá-lo como segmento de atuação das ONGs. A expressão ONG não representa, contudo, no direito brasileiro, uma forma de organização jurídica específica de entidades privadas, não sendo disciplinada em nenhum texto legislativo ou ato normativo ${ }^{206}$.

Normalmente essas entidades assumem a forma de associações ou fundações sem fins lucrativos.

A Lei Federal 9.790/99 criou as organizações da sociedade civil de interesse público - OSCIPs. Contudo, não é correto afirmar que a referida lei seja a lei do Terceiro Setor, pois existem muito poucas OSCIPs. OSCIP é uma qualificação especial, concedida pelo Ministério da Justiça às entidades da sociedade civil sem fins lucrativos que, além de cumprirem os requisitos legais, tenham por finalidade social as atividades elencadas pela referida $l \mathrm{i}^{207}$.

Essas entidades são privadas, embora possam receber recursos públicos; mas não podem distribuir lucros entre seus proprietários e administradores e envolvem um grau significativo de trabalho voluntário ${ }^{208}$.

O crescimento dos entes que integram o Terceiro Setor se deve ao redescobrimento do princípio da subsidiariedade e à crise do Estado enquanto prestador eficiente de serviços públicos. A administração pública, através da atividade de fomento, busca satisfazer as necessidades coletivas de forma indireta, através da promoção de certas atividades dos particulares, que as desenvolvem por si mesmo, com a proteção e estímulo da administração ${ }^{209}$.

Em especial, a concessão de títulos jurídicos distingue as entidades beneficiadas, inserindo-as num regime jurídico específico. Os títulos são os de utilidade pública, organização social e sociedade civil de interesse público ${ }^{210}$.

\footnotetext{
${ }^{206}$ G. Justino DE OliveIRA, Direito do Terceiro Setor, in Revista de Direito do Terceiro Setor, ano 1, n. 1, jan/jul 2007, p. 18-19.

${ }_{207}^{207}$ G. JUSTINO DE OliveIRA, Direito do Terceiro Setor cit. (nota 206 supra), pp. 20-21.

${ }^{208}$ L. C. P. BraGa, Organizações da sociedade civil de interesse público (OSCIP): promoção e construção de (novos) direitos e assessoria jurídica de caráter suplementar, in Revista de Direito do Terceiro Setor, ano 1, n.1, jan/jul 2007, pp. 261-280.

${ }^{209}$ S. L. FerReIRA DA Rocha, Coleção de temas de direito administrativo 7, Terceiro Setor, São Paulo, Malheiros, 2003, pp. 13-18. Os instrumentos jurídicos da atividade de fomento são as subvenções, auxílios, contratos de gestão, parceria, convênio e outorga de títulos.

${ }^{210}$ S. L. FERREIRA DA ROCHA, Coleção de temas cit. (nota 209 supra), p. 56. Entidades de utilidade pública buscam realizar o bem comum. As organizações sociais prestam serviços relacionados fundamentalmente às áreas da saúde e da educação.
} 
A organização social terá sempre natureza privada e não poderá distribuir lucro, devendo investir obrigatoriamente os excedentes financeiros no desenvolvimento das próprias atividades. A entidade deve ter ainda órgãos de deliberação e de direção compostos por representantes da sociedade civil e do Estado. Diferentemente das associações privadas sem fins lucrativos, nas quais a assembleia de associados é o órgão soberano, nas organizações sociais o conselho de administração foi colocado acima da assembleia ou do conselho curador, possuindo como atribuições algumas que deveriam ser privativas da assembleia, como a aprovação da alteração dos estatutos e a extinção da entidade $^{211}$.

O recebimento do título de organização social permite a celebração de um contrato de gestão com a administração, que é o instrumento para fornecimento de recursos públicos a essas entidades e também um meio de controle da aplicação desses recursos ${ }^{212}$.

Percebe-se, então, que as organizações não governamentais tem ocupado um papel de destaque cada vez maior no cenário atual, o que já tem ocorrido há algum tempo nos Estados Unidos e em outros países desenvolvidos e, mais recentemente, no Brasil.

Contudo, não é somente no Brasil que inexiste uma legislação específica sobre essas entidades e se tem sentido uma necessidade de reforma na disciplina das associações.

Na Itália, a crescente difusão desses entes também constitui uma realidade econômica e social de grandes dimensões, que traz problemas que a atual disciplina não tem sido capaz de solucionar adequadamente. Por esta razão, existe um projeto de reforma (Código de entes non profit) proposto ao governo desde o ano de 2003. O referido projeto dá especial importância aos órgãos das associações e fundações, uma vez que o escasso quadro normativo atual não é capaz de dar nenhuma garantia aos sujeitos que se relacionam com esses entes e por outro lado não consente aos últimos possuir um modelo administrativo e de gestão de referência, que possa garantir o seu funcionamento adequado e eficiente ${ }^{213}$.

${ }^{211}$ S. L. FerReIRA DA RoCHA, Coleção de temas cit. (nota 209 supra), pp. 92-99.

${ }^{212}$ S. L. FerReIRA DA Rocha, Coleção de temas cit. (nota 209 supra), pp. 120-144.

${ }^{213}$ L. GIANI, L'amministrazione ed Il controllo di associazioni e fondazioni in uma prospettiva di riforma, in Rassegna di Diritto Civile, dir. da Pietro Perlingieri, Ed. Scientifiche Italiane, 2007, pp. 348-354. Enquanto o Código Civil italiano prevê para as associações como órgãos necessários a assembleia de associados e o conselho de administração, o projeto de lei contém uma disciplina bem detalhada, envolvendo também órgãos de controle e órgãos responsáveis por resolver as disputas entre os sócios. 
O estudo do modelo americano de "non profit organizations" tem mostrado grande importância para o jurista italiano, porque ajuda a diferenciar os organismos com escopo de lucro e sem. O fato que entre os membros do ente não possa ser distribuído lucro constitui o principal aspecto de toda a disciplina das figuras de "non profit organizations". Sugere-se utilizar também no direito italiano como critério discricionário o dado da obrigatoriedade ou não da distribuição dos lucros entre os membros ${ }^{214}$.

Existem diversas causas que motivaram a proposta de reforma na Itália e a necessidade de se detalhar as estruturas organizativas das associações, mas a principal delas está ligada ao desenvolvimento das atividades de empresa por essas entidades. Elas podem desenvolver atividades de produção e troca de bens e serviços, desde que não distribuam os lucros. A princípio, as associações não eram concebidas para atuar no mercado, o que foi refletido na disciplina contida no Código Civil italiano. Contudo, hoje isso mudou, em especial em razão do papel relevante do terceiro setor na economia moderna $^{215}$.

O projeto de reforma italiano procura incentivar a participação dos associados nas assembleias (ativismo assemblear) - garantindo-lhes o direito de informação individual e a propositura de ações de responsabilidade pelas minorias contra os administradores -, bem como impedir a perpetuação dos mesmos gestores no $\operatorname{poder}^{216}$.

Em relação ao controle interno dos entes, o projeto prevê a constituição de um comitê de controle interno de gestão no interior do conselho de administração ou mesmo de um órgão autônomo encarregado do controle contábil e sobre a administração ${ }^{217}$.

\footnotetext{
${ }^{214}$ Ver M. BASILE, Associazioni, fondazioni e comitati, in Rivista do Diritto Civile, anno XXXVI, n.2, Padova, Cedam, mar/aprile 1990, p. 204.

${ }^{215}$ L. GIANI, L'amministrazione ed Il controllo cit. (nota 213 supra), pp. 348-354. O autor reflete acerca da disciplina de administração e controle - ou do modelo de governance - que se adaptaria melhor às organizações não governamentais. Por um lado, acredita ser necessário incrementar a estrutura interna das associações, mas também entende que se deve evitar o risco de impor uma super regulamentação a sujeitos que exigem flexibilidade.

${ }^{216}$ L. GIANI, L'amministrazione ed Il controllo cit. (nota 213 supra), pp. 364-383. O autor chega inclusive a sugerir, embora o projeto não contemple tal hipótese, que sejam aumentadas as hipóteses de recesso dos associados com a devolução das suas contribuições, como forma de persuasão dos administradores a evitar ou modificar determinadas decisões.

${ }^{217}$ L. GIANI, L'amministrazione ed Il controllo cit. (nota 213 supra), pp. 383-401. Nas entidades que exercem atividade empresária é prevista, inclusive, a separação das duas diversas funções de controle sobre a gestão e controle contábil.
} 
Ao comentar o referido projeto de reforma da disciplina associativa italiana, L. GIANI conclui que as características próprias das associações tornam possíveis comparações frequentes com as sociedades de capitais em questões de governança ${ }^{218}$.

Portanto, talvez também no Brasil comece a se mostrar necessário um modelo de administração e controle (governance) adequado para as organizações não governamentais, que não foi previsto no Código Civil, talvez inspirado na estrutura das sociedades de capitais, ainda mais se essas entidades passarem a exercer atividades de empresa, mantida a proibição de distribuição de lucros entre os associados.

${ }^{218}$ L'amministrazione ed Il controllo cit. (nota 213 supra), pp. 415-417. 


\section{A PERSONIFICAÇÃO DAS ASSOCIAÇÕES}

Sumário: II.1. Constituição das associações e aquisição da personalidade jurídica. II.2. Associações personificadas e não personificadas. II.3. A associação como pessoa jurídica de direito privado. II.4. Efeitos da personificação.

II.1. Constituição das associações e aquisição da personalidade jurídica

Iniciaremos o presente capítulo com a análise da constituição das associações e das formalidades necessárias à aquisição da personalidade jurídica.

A existência legal das associações, assim como as outras pessoas jurídicas de direito privado, inicia-se com a inscrição do ato constitutivo em seu respectivo registro $^{219}$. As associações que não registrarem os seus atos constitutivos serão irregulares ou não personificadas, o que não significa que não existam de fato 220221222223224225 .

\footnotetext{
${ }^{219}$ Ver artigo 45 do Código Civil de 2002.

${ }^{220}$ Ver C. A. DA Mota PINTO, Teoria Geral cit. (nota 9 supra), p. 301, acerca da constituição das pessoas coletivas e formação do substrato das corporações de direito privado: "O acto de constituição da associação, os estatutos e suas alterações estão sujeitos a exigências de forma e de publicidade. Devem constar de escritura pública, verificando-se, em caso de inobservância desta exigência, a sanção correspondente ao vício de forma: nulidade. Devem, além disso, o acto de constituição e os estatutos ser publicados no jornal oficial, sob pena de ineficácia em relação a terceiros, cabendo oficiosamente ao notário remete o respectivo extracto para publicação, bem como à autoridade administrativa e ao Ministério Público a constituição e estatutos, bem como a lalteração destes. Note-se, por outra via, que a falta de escritura pública, provocando a nulidade do acto de constituição e seus estatutos, impede o reconhecimento da associação, a qual figurará, por falta desse requisito legal (art. 158), como associação sem personalidade jurídica."

${ }^{221}$ Ver F. C. PONTES DE MiRAndA, Tratado de Direito Privado cit. (nota 4 supra), pp. 358-360 e 374-375, sobre a definição de ato constitutivo: "Em sentido largo, ato constitutivo (ou institutivo) é todo ato dos que constituem (ou instituem) a pessoa jurídica in fieri. O ato constitutivo não se refere à pessoa jurídica; referese à entidade que vai ser personificada. Em sentido estrito, mas impróprio, ato constitutivo é o ato que constitui, porém não entra na classe dos "contratos", "estatutos" ou "compromissos" (art. 18). (...) O ato constitutivo deve ser por escrito, conter as regras fundamentais da organização, o nome e o domicílio, e especificar o fim, ou fins, e observar as regras jurídicas peculiares a cada espécie de suporte fático da pessoa jurídica." Para o autor, o ato constitutivo "é sempre declaração de vontade, pluripessoal ou, excepcionalmente, unipessoal (fundação, sociedade ou associação criada por lei). O ato constitutivo é negócio jurídico, ainda quando inserto em lei. (...) O ato constitutivo, ainda quando se trate de estatutos, não é normativo, no sentido de conter regras jurídicas. O que se estabelece para reger as pessoas jurídicas de direito privado é estranho à auto-legislação. A afirmação da autonomia (= legislação para si mesmo) não pode ser deduzida da teoria do ato coletivo, posto que contra ela seja radical a teoria do negócio jurídico plurilateral, ou a do contrato. (...) Para se afirmar que o ato constitutivo ou os estatutos são direitos objetivos, Lex, complexo de normas jurídicas, seria preciso se partir da premissa de não ser negócio jurídico.”
} 
O legislador brasileiro adotou como início da existência legal das associações, consideradas pessoas jurídicas de direito privado, a data da inscrição do seu ato constitutivo no respectivo registro. Existem casos em que é necessária a prévia autorização ou aprovação do Poder Executivo para tanto. Todas as posteriores alterações do ato constitutivo deverão ser averbadas no registro, o que se exige para dar a publicidade necessária a terceiros ${ }^{226}$.

Portanto, o legislador brasileiro só reconhece a existência legal das associações quando forem inscritas no registro competente, momento em que adquirem personalidade jurídica. Não são reconhecidas as associações que não procedem ao registro dos seus atos constitutivos, as quais denominaremos associações irregulares ou não personificadas, não havendo qualquer previsão legal sobre elas, como ocorre no Código Civil italiano. As associações de fato não adquirem personalidade jurídica, e tratemos delas no item II.2.

Não poderão ser inscritos no registro competente os atos constitutivos de associações cujo objeto compreenda a prática de atividade ilícita, contrária ao bem público, à segurança do Estado ou da coletividade, à ordem pública, à moral e aos bons costumes 227.

O legislador brasileiro estabeleceu um prazo decadencial de três anos para a anulação da constituição das pessoas jurídicas de direito privado por defeito do ato respectivo, contado tal prazo da publicação de sua inscrição no registro ${ }^{228}$.

${ }^{222}$ F. C. PONTES DE MIRANDA, Tratado de Direito Privado cit. (nota 4 supra), p. 376, conceitua inscrição como "o ato estatal, de jurisdição voluntária, pelo qual se registra a associação, sociedade ou fundação, e do qual resulta o efeito personificativo."

${ }^{223}$ Segundo M. H. DINIZ, Curso de Direito Civil cit. (nota 13 supra), p. 242: “(...) sem registro, será considerada uma associação irregular (Nichtrechtsfähiger Verein), ou melhor, não personificada que, não tendo personalidade jurídica, será tida como mera relação contratual disciplinada pelo seu estatuto (Satzung)."

${ }^{224}$ C. M. DA SILVA PEREIRA, Instituições cit. (nota 22 supra), p. 232, explica que: “A falta de registro importa, como consequiência, a ausência da personalidade jurídica. Nelas não se pode, numa solução simplista, abstrair de sua existência: havendo um ato voluntário, por isso mesmo hábil em tese a gerar uma pessoa moral e havendo atuação no mundo civil, com visos de comércio jurídico, a posição negativa do direito em face de uma situação de materialidade palpável e irrecusável seria atentatória da realidade. O direito, então, adota uma posição especial, em que defende a aplicação da condição instituída para a personalização e ao mesmo tempo encara a situação real criada. Sem reconhecer personalidade jurídica ao ente irregularmente constituído, cogita dos efeitos práticos da sua existência material."

${ }^{225}$ F. C. PONTES DE MIRANDA, Tratado de Direito Privado cit. (nota 4 supra), pp. 333-334 define a associação não personificada como: "toda associação que resultou de negócio jurídico, ou de lei, mas para a qual (ainda) não se obteve personificação. Organizou-se social ou corporativamente, - não é pessoa. Falta-lhe a capacidade de direito. (...) Houve constituição de acordo com a lei e tal constituição perdura; não há capacidade de direito, mas há patrimônio que se põe em relevo, sem que coincida ser titular a associação. (...)"

${ }^{226}$ Ver o artigo 45 caput do Código Civil.

${ }^{227}$ Cf. F. C. Pontes De MiRAnDA, Tratado de Direito Privado cit. (nota 4 supra), p. 378, é garantida a liberdade de associação para obtenção de fins lícitos. 
Os associados fundadores se reúnem na primeira assembleia da entidade, para elaborar a aprovar os seus atos constitutivos, que serão levados a registro. Com a publicação da inscrição no registro, a associação já adquire a personalidade jurídica. Trataremos dos efeitos da personificação no subitem II.4.

Como já dito, a finalidade do registro é dar publicidade da constituição das associações, bem como das regras escolhidas pelos membros fundadores para reger a entidade. O legislador estabeleceu os elementos essenciais que deverão ser declarados pelo registro, que individualizam a pessoa jurídica, como a denominação, a sede, o tempo de duração e o fundo social, quando houver 229230 .

Além disso, deverão ser declarados pelo registro o nome e a individualização dos fundadores ou instituidores, e dos diretores. Os primeiros diretores normalmente são indicados no ato constitutivo ou no estatuto, devendo constar o prazo de duração de sua gestão. Os próximos já serão escolhidos por eleição, na forma prevista no ato constitutivo ou estatuto ${ }^{231}$.

Deverá ser declarado, ainda, pelo registro, o modo por que se administra e se representa, ativa e passivamente, judicial e extrajudicialmente, a associação ${ }^{232}$.

As regras referentes à administração da entidade devem ser desde já previstas, bem como a forma que a entidade será representada. Os poderes dos administradores deverão ser previstos no ato constitutivo, e obrigarão a pessoa jurídica desde que exercidos nos limites lá previstos ${ }^{233}$.

Deverá ser declarado desde já se o ato constitutivo poderá ser reformado no tocante à administração e de que forma, estabelecendo-se o quorum necessário para a tomada das deliberações ${ }^{234}$.

É necessária a declaração acerca da existência ou não de responsabilidade subsidiária dos membros pelas obrigações sociais, regra que visa à proteção de terceiros ${ }^{235}$.

\footnotetext{
${ }^{228}$ Ver o artigo 45, parágrafo único do Código Civil.

${ }^{229}$ Ver o artigo 46 inciso I do Código Civil.

${ }^{230}$ O legislador, quando menciona o fundo social “quando houver”, parece admitir que a associação possa ser criada ser patrimônio.

${ }^{231}$ Ver o artigo 46 inciso II do Código Civil.

${ }^{232}$ Ver o artigo 46 inciso III do Código Civil.

${ }^{233}$ Ver o artigo 47 do Código Civil.

${ }^{234}$ Ver o artigo 46 inciso IV do Código Civil.

${ }^{235}$ Ver o artigo 46 inciso V do Código Civil.
} 
Por fim, o registro declarará as condições de extinção da pessoa jurídica e o destino do seu patrimônio, nesse caso. A extinção da associação e o destino do patrimônio remanescente serão tratados no capítulo $\mathrm{V}$.

A pessoa jurídica associação tem um elemento material, consistente nos atos de associação e no patrimônio destinado ao alcance do fim, bem como um elemento formal, representado pelo seu estatuto e pelo reconhecimento, que a classifica como pessoa ou sujeito de direito ${ }^{236}$.

A maioria da doutrina entende que a existência legal das pessoas jurídicas de direito privado começa com a inscrição de seus contratos, atos constitutivos, estatutos ou compromissos, em seu registro público. Isso não significa, contudo, que a pessoa jurídica não possa existir antes disso, no campo dos acontecimentos, distinguindo-se entre a existência de direito e a existência no plano dos fatos ${ }^{237}$.

Posição distinta possui F. U. Coelho, que defende que o início da personificação se dá com a manifestação de vontade dos fundadores da pessoa jurídica, e não somente com o registro de seus atos constitutivos, criticando o critério escolhido pelo legislador ${ }^{238}$.

R. DE RUGGIERO explica o reconhecimento por parte do Estado não como uma criação da pessoa jurídica, e sim como uma confirmação, reconhecendo uma realidade

\footnotetext{
${ }^{236}$ Cf. L. DA C. GonÇALVES, Direito Civil cit. (nota 14 supra), p. 110. A personalidade da associação, para o autor, começa com o registro dos atos constitutivos.

${ }^{237}$ Ver S. RODRIGUES, Direito Civil cit. (nota 50 supra), p. 72: "Note-se, desde logo, a distinção entre a existência no plano do direito e a existência no plano dos fatos. Se a lei declara que a existência no plano do direito se inicia com a inscrição dos estatutos no registro peculiar, é porque, naturalmente, admite que exista no campo material uma organização subjacente, representada por um grupamento de pessoas buscando um fim comum, ou por um patrimônio separado, voltado a determinada destinação. Portanto, a compor a ideia de pessoa jurídica encontram-se dois elementos: o material, representado quer pela associação de pessoas (preexistente), quer por um patrimônio destinado a um fim; e o jurídico, constante da atribuição de personalidade, que decorre de uma determinação da lei, e cuja eficácia advém da inscrição dos estatutos no regime particular. (...) Antes da inscrição a pessoa jurídica pode existir no campo dos acontecimentos, mas o direito despreza a sua existência, nega-lhe a personalidade civil, ou seja, nega-lhe a capacidade para ser titular de direitos. O que faz com que a pessoa moral ingresse na órbita jurídica é o elemento formal, representado pela inscrição no registro competente."

${ }^{238}$ Curso de Direito Civil cit. (nota 10 supra), p. 240: "Se o atributo da personalidade é a autorização genérica para a prática de atos jurídicos não proibidos, o fato jurídico que marca o início da personificação deveria ser a manifestação de vontade dos fundadores da pessoa jurídica. Mesmo se adotando um conceito mais largo de personalidade, como a aptidão para titularizar direitos e obrigações, também não será o registro dos atos constitutivos, mas sim a manifestação da vontade dos fundadores da pessoa jurídica, o fato desencadeador da personificação. É claro que o funcionamento da pessoa jurídica antes do registro é irregular e importa, para as sociedades, por exemplo, relativizações de sua autonomia patrimonial. O registro, assim, deveria ter sido escolhido pela lei como condição para o funcionamento regular da pessoa jurídica e não para a personificação."
} 
que já existia. Contudo, confere ao reconhecimento uma eficácia retroativa, tornando perfeitos os atos praticados no passado pela entidade já constituída ${ }^{239}$.

Notamos que há controvérsias, entre os autores, acerca do momento exato de atribuição de personalidade jurídica às entidades, apesar da maioria adotar o momento do registro dos atos constitutivos ${ }^{240}$.

C. M. DA Silva PEREIRA, apesar de acompanhar a maioria dos doutrinadores, ressalta algumas peculiaridades. Explica que existem três critérios que o legislador pode adotar em atribuição da personalidade às pessoas jurídicas: o da livre formação, o do reconhecimento e o das disposições normativas, pertencendo o direito brasileiro ao último deles, mas não com absoluta rigidez, podendo ser classificado como um sistema intermediário ou misto. Para o autor existiriam, assim, duas fases na criação da pessoa jurídica: a do ato constitutivo e a da formalidade administrativa do registro ${ }^{241}$.

Há, assim, na criação da pessoa jurídica de direito privado, duas etapas: a do ato constitutivo e a da formalidade do registro. A primeira etapa é uma declaração de vontade para cuja validade devem estar presentes os requisitos de eficácia dos negócios jurídicos. Alguns procedimentos devem anteceder a assembleia geral de constituição da associação sem fins lucrativos como a elaboração do estatuto, que será discutido e aprovado em assembleia; a convocação dos associados ou sócios fundadores para participar da assembleia geral de constituição, cuja ordem do dia deverá ser a constituição

\footnotetext{
${ }^{239}$ Instituições cit. (nota 28 supra), p. 395.

${ }^{240}$ Cf. F. CARdoso, Extinção das Pessoas Colectivas de Direito Privado, Lisboa, Portugalmundo, 1989, p. 16, para haver personalidade jurídica não basta uma coletividade de pessoas ou um acervo de bens ou um escopo determinado. A personalidade jurídica tem que ser atribuída pela lei. O legislador atribui personalidade jurídica às associações através do reconhecimento por parte da autoridade administrativa competente.

${ }^{241}$ Ver C. M. DA SILVA PEREIRA, Instituições cit. (nota 22 supra), pp. 226-228. "Na primeira fase, ocorre a constituição da pessoa jurídica, por ato inter vivos nas associações (...). É sempre uma declaração de vontade, para cuja validade devem ser presentes os requisitos de eficácia dos negócios jurídicos. (...) Em se tratando de sociedades ou associações, comumente se denomina de "contrato constitutivo", (...). A segunda fase configura-se no registro (...). Também para as pessoas jurídicas foi criado o sistema de registro, por via do qual ficam anotados e perpetuados os momentos fundamentais de sua existência (seu começo e fim), bem como as alterações que venham a sofrer no curso de sua vida." O autor explica que o primeiro critério, da livre formação, "admite a criação da pessoa jurídica pela simples elaboração do seu ato constitutivo", mas qualifica tal critério como "falho e desaconselhável", por não oferecer "segurança e estabilidade". Já o segundo critério, do reconhecimento, prevê a necessidade de um decreto de reconhecimento para aquisição da personalidade jurídica. Por fim, o último critério, das disposições normativas, seria um critério intermediário, pois "outorga poder criador à vontade, ensanchando à entidade por ela criada a faculdade de adquirir personalidade independente de qualquer ato de concessão. Mas exige, por outro lado, a observância de condições legais pré-determinadas e, desde que a elas atendam, vivem e operam sem constrangimento." Para o autor, o direito brasileiro, que já pertenceu à primeira categoria, atualmente se filia ao último critério, porque "salvo casos especiais de exigência de autorização, o princípio dominante é o de que a vontade dos indivíduos, obedecendo a requisitos pré-determinados, é dotada do poder de criar a pessoa jurídica."
} 
da sociedade; a eleição dos membros que irão compor o primeiro mandato nos órgãos internos e a definição da sede provisória e, por fim, a reunião em assembleia, com a lavratura de ata, contendo as seguintes deliberações: o estatuto aprovado, os membros eleitos para integrar cada órgão interno e a sede provisória da sociedade ${ }^{242}$.

$\mathrm{Na}$ Itália, o mesmo critério de aquisição da personalidade jurídica foi escolhido pelo legislador. As pessoas jurídicas de direito privado adquirem personalidade jurídica mediante o reconhecimento por decreto do Presidente da República. As associações devem ser constituídas por ato público ${ }^{243} 244$.

As pessoas jurídicas devem ser registradas no registro público competente, devendo ser indicado a data do ato constitutivo, a data do decreto de reconhecimento, a denominação, o fim, o patrimônio, a duração, se for determinada, a sede da pessoa jurídica e o nome completo dos administradores, mencionando a quais será atribuída a representação da entidade ${ }^{245}$.

O legislador italiano prevê, também - o que não foi feito no Brasil -, disposições acerca da responsabilidade dos administradores de associações não registradas e, consequentemente, não personificadas, estabelecendo que respondem pessoalmente e solidariamente, junto com a pessoa jurídica, pelas obrigações assumidas ${ }^{246}$.

As alterações do ato constitutivo e do estatuto, após a sua aprovação pela autoridade competente, a transferência da sede e a instituição de sedes secundárias, a substituição dos administradores e a indicação dos representantes, as deliberações de dissolução e de extinção, bem como os nomes dos liquidantes, deverão ser inscritos no registro. Caso tais inscrições não sejam efetuadas, os fatos indicados não serão oponíveis a terceiros, a não ser que se prove que eles tinham ciência ${ }^{247}$.

As associações italianas que quiserem adquirir personalidade jurídica com o registro devem requerer a sua constituição através de forma solene, devendo o contrato de associação ser estipulado por ato público. O registro é necessário para o reconhecimento que elimina as possíveis dúvidas sobre a existência da associação e sobre o teor do pactuado entre os associados - e aquisição da personalidade jurídica. A falta da solenidade

\footnotetext{
${ }^{242}$ Ver J. E. S. PAES, Fundações, Associações e Entidades cit. (nota 32 supra), pp. 160-165.

${ }^{243}$ Ver artigo 12 do Código Civil italiano.

${ }^{244}$ Ver artigo 14 do Código Civil italiano.

${ }^{245}$ Ver artigo 33 do Código Civil italiano.

${ }^{246}$ Ver artigo 33 do Código Civil italiano.

${ }^{247}$ Ver artigo 34 do Código Civil italiano.
} 
ou mesmo da forma escrita não torna nulo o contrato de associação, mas a associação não será reconhecida. A formação do ato constitutivo pode ser simultânea e pode, também, ser progressiva ou continuada, formando-se o vínculo associativo, nesse segundo caso, através das adesões sucessivas tornadas públicas, nas quais são mencionados os elementos essenciais do contrato de associação. Todos os outros elementos do contrato serão determinados, por maioria, na assembleia dos membros que aderirem na denominada assembleia de constituição. Já as adesões sucessivas não necessitam de nenhuma forma especial, embora possuam valor constitutivo de vínculo associativo ${ }^{248}$.

Os associados fundadores possuem autonomia para criar a associação, escolhendo as regras apropriadas, desde que respeitem as exigências legais.

Não se pode criar associações privadas com finalidades proibidas para pessoas físicas na lei penal, associações secretas e aquelas que persigam escopos políticos mediante organizações militares e outros. Há normas que prescrevem requisitos de forma e materiais para a constituição de determinados entes e ainda para a aquisição da personalidade jurídica. $\mathrm{O}$ ordenamento garante a quem constitui o ente coletivo o direito de escolher o gênero e a espécie, o que é consentido primordialmente entre os modelos prédeterminados pelo sistema e, se feita desta forma, exige o respeito às eventuais normas inderrogáveis que estabelecem a estrutura e a função do ente, além dos requisitos necessários para constituí-1o ${ }^{249}$.

$\mathrm{O}$ ato constitutivo é sujeito às regras que prescrevem, além do conteúdo, a forma. As associações e todos os outros entes que aspiram à obtenção de personalidade jurídica devem se constituir com ato público. O código italiano não prescreve, contudo, nenhuma forma para o ato constitutivo das associações que não aspiram à obtenção da personalidade jurídica $^{250}$.

O legislador italiano recepcionou a categoria da pessoa jurídica, defendendo poder adquirir personalidade os seguintes tipos de entes: associações, fundações e

\footnotetext{
${ }^{248}$ Ver F. Galgano, Persone giuridiche cit. (nota 57 supra), pp. 191-193. A ata da assembleia que constitui a associação deverá ser redigida e anexada ao pedido de reconhecimento.

${ }^{249}$ Ver M. BASILE, Le Persone giuridiche, cit. (nota 54 supra), pp. 50-54. Para o autor, nem mesmo os referidos poderes de escolha são ilimitados. Nesse sentido, a forma das organizações de voluntariado deve ser compatível com o escopo solidário, e o seu ordenamento interno deve possuir vários requisitos incompatíveis com a estrutura de uma associação. Pode existir, contudo, entes privados atípicos. O caráter atípico do organismo criado pode se dar devido ao defeito de correspondência com o esquema tipificado de qualquer fator essencial: não só da função mas também da estrutura. Essa tese é controvertida, em especial em razão da proteção de terceiros que se relacionam com o ente, mas não faltam dados normativos de relevo que permitem a criação de entes coletivos sem vínculo com os modelos legais.

${ }^{250}$ Ver M. BASILE, Le Persone giuridiche, cit. (nota 54 supra), pp. 57-58.
} 
sociedades. Contudo, a simples criação dessas entidades não era suficiente para a aquisição de personalidade, que ocorreria somente após um reconhecimento concedido com o decreto do chefe de Estado. Enquanto o ente não era reconhecido, o direito oferecia um princípio de tutela ${ }^{251}$.

Cabia à autoridade administrativa, com a entrada em vigor do Código italiano anterior, por ocasião do reconhecimento, efetuar um controle de legalidade e de admissibilidade da adequação dos meios patrimoniais do ente em relação ao seu escopo. Algumas vezes podia examinar o mérito, considerando inoportunos entes privados que operassem para cuidar de interesses totalmente satisfeitos pela iniciativa pública. Posteriormente, o sistema administrativo perdeu um pouco a importância, introduzindo o legislador normas que determinavam que os procedimentos administrativos fossem simplificados e agilizados. Dessa forma, as associações e outras pessoas de direito privado passaram a adquirir a personalidade no momento da sua inscrição no registro. Analisava-se somente se o escopo era possível e lícito e se havia um patrimônio adequado para sua consecução ${ }^{252}$.

No ano de 2000 foi eliminado o decreto concessório de personalidade e algumas fases do procedimento foram suprimidas. Devem ser preenchidas apenas as regras legais ou regulamentares para a constituição do ente, o escopo deve ser possível e lícito e o patrimônio adequado à realização do escopo, depois deve haver inscrição no registro competente. Devem ser verificadas pela autoridade administrativa apenas a existência de circunstâncias que obstem à obtenção do registro. Trata-se do juízo de homologação procedimento declaratório, e não concessório -, parecendo não caber mais controles de mérito em relação aos escopos dos entes ${ }^{253}$.

Diferente posição possui M. BESSONE, para quem a pessoa jurídica é resultante da síntese de dois elementos: um material, constituído pelo complexo de condições e pressupostos de fato, aos quais o sistema positivo subordina a aquisição da personalidade jurídica; e um formal, representado pela qualificação jurídica e consistente na atribuição pelo ordenamento da qualidade de sujeito jurídico ao ente coletivo. $\mathrm{O}$ reconhecimento em sentido formal é a criação do ente como sujeito jurídico distinto dos

\footnotetext{
${ }^{251}$ Ver M. BASILE, Le Persone giuridiche, cit. (nota 54 supra), pp. 135-138.

${ }^{252}$ Ver M. BASILE, Le Persone giuridiche, cit. (nota 54 supra), pp. 159-161.

253 Ver M. BASILE, Le Persone giuridiche, cit. (nota 54 supra), pp. 164-168. Para o autor, como o legislador liga o registro à concessão da personalidade jurídica, apenas nesse sentido poderia se sustentar que o procedimento é constitutivo, no sentido de aquisição formal da subjetividade jurídica.
} 
indivíduos que o compõem e dotado de autonomia patrimonial perfeita. Tal reconhecimento tem para o autor valor constitutivo da pessoa jurídica. Difere do reconhecimento em sentido material, consistente em um ato administrativo ou um provimento de jurisdição voluntária, ligado ao substrato substancial da pessoa jurídica. Também possui para o autor valor e função constitutivos ${ }^{254}$.

O legislador francês estabeleceu, da mesma forma, que as associações de pessoas podem se formar livremente, sem autorização ou declaração prévia, mas só obterão personalidade jurídica se seguirem as disposições legais, ou seja, se tornarem público seu ato constitutivo. As alterações do ato constitutivo também devem constar de um registro especial $^{255}$.

Nesse sentido, uma associação não declarada é legal, mas não possui personalidade jurídica ou patrimônio, não podendo contratar ou receber subvenções, doações ou legados, nem responder civilmente, penalmente ou administrativamente. Os bens adquiridos por uma associação sem personalidade jurídica pertencem à propriedade indivisa de seus membros ${ }^{256}$.

Assim, existem na França associações de fato, que são grupamento de pessoas que não efetuaram nenhuma declaração de existência, não possuem patrimônio nem capacidade de direito; associações declaradas, que são a forma mais comum, que seguem as formalidades legais e possuem capacidade jurídica e associações de utilidade pública reconhecida, quando a autoridade competente reconhece a importância e o papel de utilidade pública da entidade, que deverá respeitar determinadas obrigações ${ }^{257}$.

Houve, na França, um longo período de hostilidade até a liberdade de associação ser reconhecida pela Lei francesa de 1901, permitindo a sua constituição sem a necessidade de autorização. Sua validade é apreciada de acordo com os princípios gerais de direito aplicáveis aos contratos e obrigações. É, portanto, nula uma associação fundada por causa ou tendo em vista um objeto ilícito, contrário à lei, aos bons costumes ou que tenha

\footnotetext{
254 Casi e questioni di diritto privato, I - Persone fisiche e persone giuridiche, pp. 283-295. O reconhecimento material, para o autor, analisa os escopos do ente, a consistência da estrutura organizativa, a licitude dos fins, a regularidade formal dos atos do ente, inclusive a existência de um ato constitutivo válido. O reconhecimento poderia ser negado se o ente possuísse uma estrutura organizativa excessivamente exígua em relação à complexidade dos fins perseguidos ou ainda se tivesse escopos tão genéricos que tornassem impossível uma avaliação de suficiência do patrimônio.

${ }^{255}$ Ver artigos $2^{\circ}$ e $5^{\circ}$ da Lei de $1^{\circ}$ de julho 1901.

${ }^{256}$ S. DEMAREY et al, Code cit. (nota 34 supra), pp. 31-32.

${ }^{257}$ P. DelamarRe, Créer e faire vivre cit. (nota 37 supra), pp. 16-18.
} 
por finalidade ameaçar a integridade do território nacional e a forma republicana do governo. A associação não declarada não se beneficia da personalidade jurídica ${ }^{258}$.

O legislador alemão também adotou o critério do registro da associação sem finalidade lucrativa para aquisição da personalidade jurídica ${ }^{259}$.

Existem disposições acerca das associações sem personalidade jurídica, em especial no tocante à responsabilidade dos associados ${ }^{260}$.

O requerimento de registro deve ser efetuado pelos diretores da associação, devendo ser apresentado o estatuto e a ata da eleição ou indicação dos administradores. Poderá ser rejeitado se determinados requisitos não forem observados, como o número mínimo de sete associados, ou ainda se o estatuto não contiver os elementos essenciais da associação, como: o objeto; a denominação; a sede; as condições de admissão e retirada dos associados; a previsão da existência e forma das contribuições dos associados; a composição dos órgãos de administração e as condições para a convocação e realização das assembleias e registro de suas deliberações ${ }^{261}$.

O registro deve conter a denominação e a indicação da sede da associação, a data de registro do estatuto, a nomeação dos administradores e dos representantes. Junto à denominação da associação deverá ser anexada a expressão "associação registrada"262.

Como já mencionado, as alterações ao ato constitutivo e estatuto só serão válidas se forem registradas ${ }^{263}$.

O nascimento da associação se dá por etapas. Exige-se em primeiro lugar a sua fundação, ou seja, a criação da estrutura corporativa pelos fundadores através de negócio jurídico. Em seguida são elaborados os estatutos, que devem conter a finalidade da entidade. Se ela for se inscrever deverá constar o seu nome, a sede, as regras relativas à incorporação e separação, aportes, eleição da diretoria e a assembleia de associados. Com o acordo dos fundadores sobre os estatutos e expressada a sua vontade de serem membros da associação, nasce a associação em formação ${ }^{264}$.

\footnotetext{
${ }^{258}$ Cf. B. TEYssiÉ, Droit Civil cit. (nota 38 supra), p. 314.

${ }^{259}$ Ver título 2, subtítulo 1, capítulo 1, seção 21 do Código Civil alemão.

${ }^{260}$ Ver título 2, subtítulo 1, capítulo 1, seção 54 do Código Civil alemão.

${ }^{261}$ Ver título 2, subtítulo 1, capítulo 1, seções 56 a 60 do Código Civil alemão.

${ }^{262}$ Ver título 2, subtítulo 1, capítulo 1, seções 64 e 65 do Código Civil alemão.

${ }^{263}$ Ver título 2, subtítulo 1, capítulo 1, seção 71 do Código Civil alemão.

${ }^{264}$ Cf. F. KÜBLER, Derecho de Sociedades cit. (nota 61 supra), p. 204.
} 
O ordenamento jurídico conferirá capacidade jurídica a esta associação em formação. Pode ocorrer por meio de uma norma geral (sistema da livre criação das corporações), por meio de um ato administrativo (sistema de concessão) e pelo cumprimento de determinados pressupostos fundacionais, o que se controla através da exigência de inscrição constitutiva (sistema das condições normativas). Uma ou outra poderá ser adotada em função da sede e da finalidade da associação. Deve-se distinguir entre as associações com ou sem finalidade lucrativa, pois às segundas se aplica o sistema das condições normativas, adquirindo personalidade jurídica com a sua inscrição no registro de associações. Já para as primeiras, vige o sistema de concessão, somente adquirindo personalidade jurídica quando a autoridade competente territorialmente a concede, o que ocorre de forma muito excepcional, porque se procura evitar que a forma de associação seja utilizada para a exploração de uma empresa mercantil ${ }^{265}$.

$\mathrm{Na}$ Argentina a existência das pessoas jurídicas começa no dia em que foram autorizadas pela lei ou pelo governo, com aprovação de seus estatutos. As associações que não tiverem existência legal como pessoas jurídicas serão consideradas como simples associações civis ou religiosas, segundo o fim de seu instituto. Serão sujeitos de direito sempre que a constituição e designação de autoridades se derem por escritura pública ou instrumentos privados de autenticidade certificada por escrevente público. Se não forem, todos os membros fundadores da associação e seus administradores assumem responsabilidade solidária por todos os atos dela ${ }^{266}$.

Assim, concluímos que o critério do legislador brasileiro para o início da existência legal das associações é a inscrição dos seus atos constitutivos no registro competente, condição para a aquisição da personalidade jurídica.

Embora não exista previsão legal, nem regras acerca do seu funcionamento, existem também as associações irregulares ou não personificadas, que não foram levadas a registro e não adquirem personalidade jurídica, apesar de existirem de fato.

A omissão do legislador brasileiro em sua regulação traz incertezas acerca do regime jurídico adequado - o que foi previsto em outros países -, em especial no tocante à responsabilidade da entidade e dos associados.

\footnotetext{
${ }^{265}$ Cf. F. KÜBLER, Derecho de Sociedades cit. (nota 61 supra), pp. 204-209.

${ }^{266}$ Cf. M. DANiElian e J. I. B. Peret, Personas Juridicas cit. (nota 39 supra), pp. 9-10.
} 
Como já mencionado, as formalidades previstas, como o registro do ato constitutivo e estatutos da associação, bem como de suas alterações, têm como finalidade dar a publicidade necessária aos atos para proteção de terceiros que poderão, desta maneira, conhecer a organização interna, as condições patrimoniais e as pessoas responsáveis pela administração e representação dos entes.

Atualmente parece não haver um controle de mérito da autoridade administrativa para o registro da associação, ou talvez este controle ocorra de forma muito limitada, tratando-se na verdade de homologação, com a conferência dos requisitos necessários ao registro.

\section{II.2. Associações personificadas e não personificadas}

O Código Civil brasileiro não tratou das associações não personificadas, diferentemente do que fez o legislador italiano. As associações personificadas e não personificadas no direito italiano são submetidas a regimes diferentes, embora haja uma tendência recente a minimizar algumas distinções. As últimas são muito comuns na Itália.

Sendo assim, existe uma lacuna, no direito brasileiro, acerca da disciplina aplicável às associações não personificadas, havendo dúvidas acerca de a qual regime jurídico deveriam se submeter. O tema é relevante especialmente em relação a terceiros, pois se a associação não possui capacidade jurídica ou patrimônio autônomo, e sim apenas um patrimônio em comum, deve haver regras especiais de proteção aos credores, em especial em relação à responsabilidade dos associados.

Trataremos dos efeitos da personificação no subitem II.4. Por ora, analisaremos a distinção entre associações personificadas e não personificadas, em especial destacando as regras distintas aplicadas a cada uma delas.

Alguns autores brasileiros procuraram tratar da disciplina que seria aplicável às associações que não registraram os seus atos constitutivos, e, consequentemente, não adquiriram personalidade jurídica, denominadas associações de fato, irregulares ou não personificadas. 
Nesse sentido, M. H. DINIZ entende que tais associações sem registro serão consideradas irregulares, ou melhor, não personificadas e, não tendo personalidade jurídica, serão tidas como mera relação contratual disciplinada por seu estatuto ${ }^{267}$.

A maioria da doutrina, como relatado no item anterior, defende que, apesar de não adquirir personalidade jurídica, a associação não personificada existe, o que é reconhecido pelo direito, gerando efeitos práticos ${ }^{268}$.

Apesar de não adquirir a qualificação de pessoa jurídica, a associação possui um patrimônio, do qual não é titular, por se entender não haver capacidade de direito ${ }^{269}$.

O Código Civil brasileiro não tratou das associações não personificadas, e sim somente das sociedades não personificadas. A sociedade em comum, uma das espécies de sociedades não personificadas, possui um patrimônio especial, composto pelos bens e dívidas sociais, do qual os sócios são titulares em comum ${ }^{270}$.

Além disso, é prevista a responsabilidade solidária e ilimitada dos sócios pelas obrigações sociais ${ }^{271}$.

Entendemos, assim, que o legislador brasileiro deveria ter previsto regras semelhantes para a associação não personificada, em especial a existência de um patrimônio em comum dos associados, bem como a sua responsabilidade ilimitada e solidária pelas obrigações da associação.

O legislador italiano tratou das associações não reconhecidas em um capítulo específico do Código Civil. Foi disposto que a sua organização interna e administração serão reguladas pelos acordos de associados. As contribuições dos membros e os bens adquiridos com elas constituem o fundo em comum da associação. Pelas obrigações da associação respondem pessoalmente e solidariamente as pessoas que tiverem agido em nome e por conta da entidade ${ }^{272}$.

A gestão e a disposição dos bens do patrimônio comum são feitas pela coletividade. $\mathrm{O}$ associado não pode dispor individualmente dos bens do fundo comum, os

\footnotetext{
${ }^{267}$ Curso de Direito Civil cit. (nota 13 supra), p. 242.

${ }^{268}$ Ver C. M. DA SILVA PEREIRA, Instituições cit. (nota 22 supra), p. 232.

${ }^{269}$ Ver F. C. Pontes DE MiRAndA, Tratado de Direito Privado cit. (nota 4 supra), pp. 333-334. O autor conceitua a associação não personificada como toda associação que resultou de negócio jurídico, ou de lei, mas para a qual ainda não se obteve personificação. Não sendo pessoa, falta-lhe a capacidade de direito. Há, contudo, um patrimônio que se põe em relevo, sem que coincida ser titular a associação.

${ }^{270}$ Ver artigo 988 do Código Civil.

${ }^{271}$ Ver artigo 990 do Código Civil.

${ }^{272}$ Capo III, arts. 36 a 38 do Código Civil italiano.
} 
quais são rigidamente vinculados ao alcance do escopo. Reconhece-se à coletividade portadora do interesse coletivo, enquanto sujeito, a titularidade do fundo comum, enquanto é esta que pode dispor como dominus. Por estas razões parece evidente que as relações jurídicas ocorrem entre cada associado e o ente e não entre os associados diretamente. As prestações das partes são dirigidas à constituição do fundo patrimonial necessário ao funcionamento de um ente com um objetivo: a causa é a constituição de uma entidade subjetivizada com um escopo de natureza associativa ${ }^{273}$.

A controvérsia existente em torno das associações não reconhecidas diz respeito, sobretudo, a questões de capacidade.

Devemos analisar, nesse sentido, se o reconhecimento por parte do Estado possui eficácia constitutiva ou meramente declarativa da personalidade de uma determinada entidade, reconhecendo o legislador o que já existe na prática social. Essa é a principal questão analisada pelos doutrinadores italianos, no sentido de ser possível admitir uma pluralidade de pessoas reunidas existente somente de fato, independentemente do reconhecimento estatal, com atribuição de capacidade jurídica, adquirindo efeitos análogos àqueles que obteria se fosse verdadeira pessoa jurídica, problema ligado à teoria dos sujeitos de direito.

O Código Civil italiano anterior não tipificava as associações de fato.

Segundo A. GiovenE as associações de fato são os grupos de pessoas, vistas como uma pluralidade de indivíduos, organizada como uma unidade para atingir um determinado escopo que, todavia, não é considerada como um sujeito autônomo de direitos e de obrigações. É uma unidade natural ou empírica, que se apresenta como um todo único, mas sem unidade jurídica, pois juridicamente é apenas uma pluralidade de sujeitos ${ }^{274}$.

Nas associações existe uma vontade coletiva, que é resultante da união das vontades individuais, e que precisa, para atuar, de uma organização. Do ponto de vista da organização, pode-se dizer que não existe diferença relevante do ponto de vista externo da coletividade unificada daquela que não o é, pois a última também possui os mesmos órgãos da primeira, entre os quais se divide a soma dos poderes. Para o surgimento de uma

\footnotetext{
${ }^{273}$ Ver A. CARLO, Il contratto plirilaterale associativo, Napoli, Eugenio Jovene, 1967, pp. 161-163.

${ }^{274}$ Le associazioni di fatto nel diritto privato, Milano, Dottor Francesco Vallardi, 1914, p. 3.
} 
associação, porém, a coletividade deve ser resultado de um vínculo jurídico, de uma ligação entre vários associados, ou seja, de uma relação jurídica entre eles constituída ${ }^{275}$.

A associação para A. GIOVENE é um contrato sui generis - que não pode ser confundido com nenhuma outra figura tradicional de contrato, ou nela se enquadrar -, e nominado. Sendo assim, aplicam-se às associações de fato por analogia as normas das convenções expressamente disciplinadas a que se pareçam mais, além das normas das sociedades civis. Contudo, pela natureza dos atos das associações reputados comerciais se aplicam as normas das sociedades comerciais irregulares ${ }^{276}$.

$\mathrm{Na}$ ausência de disposições estatutárias, algumas regras da sociedade poderiam ser aplicadas às associações, como o fato da qualidade de associado não ser transmissível; a possibilidade de exclusão e aplicação de outras sanções a um associado através de deliberação da assembleia e o direito de retirada, havendo motivo relevante ${ }^{277}$.

Seguindo esse raciocínio, a capacidade das associações de fato seria aquela dos seus associados, individualmente considerados. As entidades poderiam, portanto, adquirir bens onerosos através das pessoas que a compõem e também litigar em juízo ${ }^{278}$.

O patrimônio da associação não reconhecida seria tratado, assim, como patrimônio de uma sociedade não personificada. Nas relações jurídicas, a entidade não agiria em nome próprio, e sim em nome de seus associados. Pode demandar e ser demandada em nome de seu representante ${ }^{279}$.

F. FERRARA explica que as associações não reconhecidas assemelham-se às reconhecidas no que se refere à constituição e funcionamento, o que é um risco para os terceiros e para os próprios associados, pois cria uma ilusão de posição jurídica. Isso se

\footnotetext{
${ }^{275}$ Ver A. GIOVENE, Le associazioni cit. (nota 274 supra), pp. 56-57.

${ }^{276}$ Le associazioni cit. (nota 274 supra), pp. 76-79

${ }^{277}$ Ver A. GIOVEne, Le associazioni cit. (nota 274 supra), pp. 139-146. Apesar de defender a aplicação às associações de fato das normas das sociedades civis ou das sociedades comerciais irregulares, o autor admite derrogações a essas disciplinas. A primeira delas é referente ao princípio da maioria, não aplicável nas sociedades civis, mas que se mostra nas associações de fato, em caso de silêncio do estatuto, como uma condição para o desenvolvimento de suas atividades, muitas vezes em razão do número elevado de associados. Outra norma que, ante a omissão do estatuto mereceria derrogação, é aquela que estabelece para a sociedade de pessoas a dissolução dela, em caso de morte, interdição, insolvência, ou falência de um dos sócios. Nenhum associado pode também pedir a dissolução da entidade, como ocorre nas sociedades. Por fim, nem todas as normas das sociedades comerciais irregulares poderiam ser aplicadas às associações de fato ditas comerciais, em razão da sua organização e do diferente escopo a que aspiram.

${ }^{278}$ Ver A. GIOVENE, Le associazioni cit. (nota 274 supra), pp. 102-103.

${ }^{279}$ Ver A. GIOVENE, Le associazioni cit. (nota 274 supra), pp. 157-208.
} 
deve também em razão do princípio da capacidade processual das associações, elaborado de forma lenta na Itália, mas que hoje é dominante ${ }^{280}$.

O novo Código Civil italiano afastou as associações não reconhecidas das sociedades e as aproximou das associações reconhecidas. Chegou a criar um verdadeiro patrimônio autônomo para essas entidades de fato, mas manteve a ideia de que a associação não reconhecida é somente a relação de um conjunto de sujeitos, regulado de forma especial. A atribuição da personalidade por parte do Estado é um critério de política legislativa, não de técnica jurídica. Ainda assim, para alguns, do ponto de vista jurídico não existem diferenças significativas entre as espécies ${ }^{281}$.

Contudo, produzem efeitos jurídicos diversos. O regime interno e a administração das associações não reconhecidas, pelo novo código, são regulados pelos acordos dos associados. Apesar de não haver menção à aplicação subsidiária das normas sobre associações reconhecidas, admite-se a existência de uma analogia entre as associações não reconhecidas e reconhecidas. Para outros, não existiria aplicação analógica, mas resultados semelhantes se atingem com outros caminhos, como a aplicação das cláusulas dos estatutos, das cláusulas de uso, princípios gerais, e outros ${ }^{282}$.

Para C. GANGI foi atribuída às associações não reconhecidas uma autonomia substancial patrimonial - mas não formal -, uma capacidade jurídica limitada, o que não quer dizer que possuam personalidade jurídica, seja limitada ou incompleta. O que se pode admitir é que somente para determinadas relações é reconhecida a elas uma certa individualidade jurídica, resultante de uma limitada capacidade jurídica, e substancialmente também de uma ampla autonomia patrimonial ${ }^{283}$.

Em relação à matéria processual e à representação, o novo código elevou as associações não reconhecidas às mesmas condições das reconhecidas. Não existe, porém, verdadeira capacidade processual da associação não reconhecida, mas ela poderá atuar em juízo através de seu representante processual. Não se produz uma verdadeira substituição

\footnotetext{
${ }^{280}$ Le Persone giuridiche, Torino, Unione Tipografico-Editrice Torinese, 1958, pp. 400-410. Menciona-se que, por influência do direito alemão, que remeteu às associações não reconhecidas os princípios da sociedade, alguns doutrinadores italianos passaram a defender que às associações não reconhecidas deveria ser dado o mesmo tratamento que às pessoas jurídicas, com o que discorda o autor. Por outro lado, também entende que não é correto negar a existência dessas entidades, como faziam os franceses. A posição das associações não reconhecidas deveria ser para ele inferior à das pessoas jurídicas.

${ }^{281}$ Cf. D. Rubino, Las Asociaciones no Reconocidas, Madrid, Editorial Revista de Derecho Privado, 1952, pp. 13-39.

${ }^{282}$ Cf. D. RuBINO, Las Asociaciones cit. (nota 281 supra), pp. 13-45.

${ }^{283}$ Persone fisiche e persone giuridiche, $2^{\mathrm{a}}$ ed., Milano, Giuffrè, 1948, pp. 272-274.
} 
processual, atuando o representante em juízo não em nome próprio, e sim em nome de todos os associados, que são parte na relação jurídica substancial discutida em juízo e na relação processual ${ }^{284}$.

As contribuições dos associados e os bens adquiridos com elas constituem o fundo comum da associação. As aquisições das associações podem se dar com as contribuições dos associados e também a título gratuito, originário ou mediante subrogações. O fundo comum compreende não só os direitos, mas também as dívidas da entidade $^{285}$.

Nas associações não reconhecidas responde unicamente o patrimônio comum sobre as suas dívidas, excluindo a responsabilidade pessoal e ilimitada dos membros. A posição do fundo comum foi equiparada pela lei à do patrimônio de pessoa jurídica, apesar do titular do patrimônio não ser a pessoa jurídica e sim o complexo de $\operatorname{associados}^{286}$.

A retirada de um associado não determina para os demais o desfazimento dos direitos compreendidos no fundo comum. Extinguem-se automaticamente em relação ao retirante todos os direitos e obrigações associativas que são inseparáveis da qualidade de membro, mas permanecem aquelas que, embora sua origem seja ligada à posição de membro, assumiram mais tarde uma existência autônoma. O retirante se desliga das obrigações sociais em relação a terceiros, dos quais era, como membro, codevedor ${ }^{287}$.

Nas associações não reconhecidas o ato constitutivo e o estatuto podem ser concluídos oralmente. São elementos essenciais as contribuições dos associados e os seus órgãos, pois ambos devem ser constituídos desde a origem das associações, sendo as cláusulas dirigidas à sua criação elementos essenciais do contrato associativo ${ }^{288}$.

\footnotetext{
${ }^{284}$ Cf. D. RuBINO, Las Asociaciones cit. (nota 281 supra), pp. 13-45.

285 Las Asociaciones cit. (nota 281 supra), pp. 171-191. Contudo, nem todos os aportes dos associados ingressam como parte do fundo comum. Por exemplo, quando a contribuição consiste em obrigações de fazer ou não fazer, não se cria uma comunidade entre todos os membros e sim simplesmente se tem uma obrigação indivisível, com um membro devedor e todos os demais membros credores. Neste caso a contribuição não integra o fundo comum, restando no plano das relações obrigatórias entre os membros. O fundo patrimonial para o autor é uma comunidade entre os associados, do tipo germânico, segundo o código italiano, enquanto as sociedades civis são comunidades do tipo romano. Nas associações não reconhecidas o membro não pode pedir a divisão da entidade sem pleitear a sua dissolução. Não pode pleitear a divisão sobre o fundo comum e a qualidade de membro é intransmissível. Os credores pessoais do associado não podem proceder a uma execução sobre o direito deste sobre o fundo comum. $\mathrm{O}$ fundo comum é um direito único, do qual são cotitulares todos os membros como tais.

${ }^{286}$ Cf. D. RuBINO, Las Asociaciones cit. (nota 281 supra), pp. 171-191.

${ }^{287}$ Cf. D. RuBINO, Las Asociaciones cit. (nota 281 supra), pp. 192-214.

${ }^{288}$ Cf. D. RUBINO, Las Asociaciones cit. (nota 281 supra), pp. 49-108.
} 
A lei não tratou da invalidade das deliberações tomadas pela assembleia de associações não reconhecidas, sendo necessário se proceder a uma adaptação dos princípios gerais em matérias de invalidades às características particulares da deliberação em assembleia ${ }^{289}$.

Há omissão ainda em relação à exclusão dos membros das associações não reconhecidas, sendo necessário se recorrer aos princípios gerais, temperando-os com as exigências e características do fenômeno associativo. Não basta qualquer descumprimento de uma obrigação para determinar a exclusão do membro, sendo necessária uma violação repetida e grave, por se tratar de contrato de execução continuada ${ }^{290}$.

Os efeitos externos do contrato associativo - relação com terceiros, estranhos à entidade, que não sejam nem membros nem órgãos - sujeitam-se a algumas regras especiais, em razão de aparecer uma associação não reconhecida como titular de um dos lados da relação ${ }^{291}$.

Os associados não respondem pessoalmente pelas dívidas do contrato, limitando-se, a ação executiva dos credores, ao fundo comum, acrescida de uma responsabilidade pessoal do representante da associação não reconhecida. A responsabilidade pessoal do representante possui uma função de garantia para os terceiros contratantes, que podem acionar indiferentemente primeiro o fundo comum e depois o patrimônio pessoal do representante, ou ambos ao mesmo tempo. O representante que arcou com a dívida tem direito de indenização em face do patrimônio social. Entende-se que a responsabilidade do fundo comum e do representante são solidárias ${ }^{292}$.

A prática de um ato ilícito extracontratual por pessoa investida pela associação acarreta a responsabilidade do autor e também do conjunto de todos os associados, tratando-se de caso de solidariedade. Contudo, se o ato ilícito tiver sido cometido mediante uma execução inexata de ordem ou no âmbito da discricionariedade

\footnotetext{
${ }^{289}$ Cf. D. RuBINO, Las Asociaciones cit. (nota 281 supra), pp. 111-147. O autor explica que o problema adquire caráter casuístico. Quando uma deliberação afetar diretamente e somente direitos privilegiados ou direitos de participação de um ou mais membros determinados, será ineficaz em relação àqueles sujeitos determinados. Configurando caso de anulação, a legitimidade para propor ação de anulação caberia somente a esses membros. Nos outros casos, a impugnação de deliberação se dirige normalmente à tutela dos interesses da coletividade, possuindo legitimidade cada um dos órgãos e cada um dos membros.

${ }^{290}$ Cf. D. RuBinO, Las Asociaciones cit. (nota 281 supra), pp. 192-214. O autor defende que a cláusula que permite à associação excluir um associado deve ser considerada como cláusula de uso, valendo mesmo no silêncio do ato constitutivo e do estatuto. Cláusulas prevendo a exclusão ad nutum seriam nulas, por ser contrárias à ordem pública e aos bons costumes, bem como cláusulas que proibissem o associado de recorrer à autoridade judicial.

${ }^{291}$ Cf. D. RuBINO, Las Asociaciones cit. (nota 281 supra), pp. 148-162.

${ }^{292}$ Cf. D. RuBINO, Las Asociaciones cit. (nota 281 supra), pp. 217-246.
} 
que a ordem tivesse dado ao órgão executivo, não haverá a responsabilidade solidária com os associados ${ }^{293}$.

Diversas são as causas que acarretam a dissolução da associação não reconhecida. No silêncio do ato constitutivo e do estatuto, não se requer a unanimidade dos membros para a dissolução, bastando um acordo da maioria, desde que seja notificado aos membros que não fizeram parte da deliberação ${ }^{294}$.

A revogação do reconhecimento estatal de uma associação reconhecida somente extingue a sua personalidade jurídica, mas não a relação associativa, ou seja, não dissolve a entidade, que continua existindo como associação de fato. A alteração das normas vale a partir da perda do reconhecimento ${ }^{295}$.

$\mathrm{Na}$ Espanha, F. C. RONCERO ressalta que em determinadas épocas as diferenças de tratamento entre as associações com e sem personalidade jurídica eram evidentes, tendo em vista que as últimas eram consideradas irrelevantes para o Estado. Além disso, elas não tinham acesso ao tratamento particular e privilegiado que era conferido pela outorga de personalidade, em especial a capacidade para adquirir bens e a irresponsabilidade dos associados pelas dívidas contraídas na associação, características dos entes com absoluta separação patrimonial ${ }^{296}$.

Por outro lado, as associações sem personalidade jurídica não são ignoradas e irrelevantes para o Estado, como se quis defender em determinadas épocas. A outorga de personalidade jurídica implica no acesso ao tratamento privilegiado, e não em que o Poder Público considere relevante somente as associações com personalidade ${ }^{297}$.

\footnotetext{
${ }^{293}$ Cf. D. RuBINO, Las Asociaciones cit. (nota 281 supra), pp. 217-246.

${ }^{294}$ Cf. D. Rubino, Las Asociaciones cit. (nota 281 supra), pp. 249-258. Dentre as causas de dissolução, o autor a vontade dos membros; a verificação de uma condição resolutiva; o decurso do termo final fixado no ato constitutivo; o alcance do fim; a impossibilidade superveniente (fortuita ou culposa) ou ilicitude do fim e a perda de todos os membros de uma vez e por providência da autoridade pública administrativa competente. O fim pode se tornar inexeqüível por circunstâncias internas ou externas à associação. Além disso, a extinção voluntária pode ocorrer não só os casos de dissolução pura e simples, como também mediante a absorção por outra associação, ou mediante a fusão de duas associações que originem uma nova associação, ou mediante o fracionamento em pequenas associações.

${ }^{295}$ Cf. D. RuBINO, Las Asociaciones cit. (nota 281 supra), pp. 249-258. A situação é igual, porém contrária à que se opera quando uma associação não reconhecida obtém o reconhecimento, passando a alteração das normas aqui a valer a partir do momento da obtenção do reconhecimento.

296 La Persona Jurídica: Funciones e Disfunciones, Madrid, Tecnos, 1984, p. 109. A concessão da personalidade jurídica acarreta um tratamento privilegiado, o que não impede que possam existir associações excluídas de tal tratamento. Em especial, outorgaria aos associados e administradores o benefício da limitação da responsabilidade, não respondendo estes com o seu patrimônio pessoal pelas dívidas contraídas pelo exercício da atividade associativa.

${ }^{297}$ Ver F. C. RONCERO, La Persona Jurídica cit. (nota 296 supra), p. 117.
} 
Apesar de o Código Civil italiano ter tratado das associações não personificadas em poucos artigos, M. BASILE explica que não é dada às associações sem personalidade jurídica uma posição marginal e secundária em relação às personificadas, na realidade e no sistema jurídico. Antigamente, de fato, eram vistas como marginais. As poucas regras existentes garantiam um mínimo de tutela, sobretudo para proteger terceiros que mantivessem relações com os entes não personificados. O espaço por elas ocupado tem, contudo, crescido, e as diferenças com as personificadas têm se reduzido, podendo se sustentar um discurso unitário para ambas, ressaltando as diferenças onde ainda houver ${ }^{298}$.

As diferenças entre as pessoas jurídicas e os entes não personificados foram revistas, concedendo aos últimos uma subjetividade semelhante à possuída pelas primeiras. Existe no direito italiano uma tendência a equiparar associações não reconhecidas com as reconhecidas. O desenvolvimento de um regime jurídico comum a ambas foi favorecido pela propensão legislativa emergente que tendeu a simplificar o sistema de controles públicos sobre os entes ${ }^{299}$.

A disciplina da organização interna das associações italianas não reconhecidas é remetida aos acordos de associados. O Código Civil se refere apenas a um "fundo comum" composto pelas contribuições dos inscritos e pelos bens adquiridos com ele, não prescrevendo nenhuma forma para o ato constitutivo de tais entes ${ }^{300}$.

Contudo, parece que a atribuição da personalidade jurídica tem perdido a sua importância, uma vez que muitos princípios comuns a todos os sujeitos de direito têm sido aplicados aos entes não personificados, podendo a subjetividade dos últimos ser atribuída de forma implícita ${ }^{301}$.

A aplicação a uma associação não reconhecida das normas ditadas para as associações com personalidade jurídica continua sendo, contudo, controversa.

A constituição da associação não reconhecida não é sujeita a nenhuma forma especial. Pode resultar do comportamento dos membros do grupo organizado, na qual se identifique a intenção de praticar de forma permanente uma atividade comum, de

\footnotetext{
${ }^{298}$ Le Persone giuridiche cit. (nota 54 supra), pp. 18-19.

${ }^{299}$ Cf. M. BASILE, Le Persone giuridiche cit. (nota 54 supra), pp. 24-26.

${ }^{300}$ Cf. M. BASILE, Le Persone giuridiche cit. (nota 54 supra), pp. 55-57.

${ }^{301}$ Cf. M. BASILE, Le Persone giuridiche cit. (nota 54 supra), pp 173-177. O autor narra que nas últimas décadas houve atribuição legislativa de direitos e obrigações também às associações não personificadas, como a capacidade imobiliária. A sua subjetividade é, portanto, em termos de capacidade de direitos, semelhante à das associações reconhecidas. Sendo assim, defende que a separação de disciplinas não é total, podendo ser estudada de forma unitária, com ressalva de algumas diferenças para as associações não reconhecidas.
} 
se sujeitar a um regulamento interno e de se dotar de uma organização e dos meios econômicos necessários. A doutrina e a jurisprudência têm reconhecido a natureza contratual dessas manifestações ${ }^{302}$.

A adesão a associações já constituídas não demanda, salvo acordo expresso dos associados, nenhuma forma em particular. A jurisprudência tem aplicado para as associações não reconhecidas normas das reconhecidas e de sociedades de pessoas, porque não têm finalidade lucrativa ${ }^{303}$.

Os associados possuem o direito de recesso da associação, o que se deriva do seu caráter consensual, sendo tal norma derrogável pelo estatuto. M. BESSONE defende que o recesso deveria ser permitido também nas associações não reconhecidas a prazo indeterminado, quando houver previsão no estatuto ou ato constitutivo justificada com determinados motivos, como uma modificação deles não aprovada pelo associado e sempre que houver justa causa. As cláusulas que excluírem ou tornarem muito oneroso o recesso seriam nulas ${ }^{304}$.

Parece que a doutrina e a jurisprudência têm entendido que o reconhecimento não é indispensável para a aquisição da qualidade de sujeito de direito aos grupos organizados. As noções de pessoa jurídica e de sujeito de direito não são coincidentes, pois existem grupos não dotados de personalidade jurídica que possuem subjetividade jurídica, como as associações não reconhecidas ${ }^{305}$.

Já existem entendimentos no sentido de que o fundo comum das associações não personificadas constitui um patrimônio distinto e separado do patrimônio dos membros. Pertenceria, assim, à associação, que mesmo não sendo reconhecida, teria capacidade de ser titular de relações jurídicas patrimoniais também de natureza imobiliária e real ${ }^{306}$.

A subjetividade das associações não reconhecidas faz com que as obrigações assumidas pelas pessoas que a representam sejam obrigações próprias da associação. Contudo, pelas obrigações das associações não reconhecidas respondem

\footnotetext{
${ }^{302}$ Ver M. Bessone, Casi e questioni cit. (nota 254 supra), pp. 66-67.

${ }^{303}$ Ver M. Bessone, Casi e questioni cit. (nota 254 supra), p. 69.

${ }^{304}$ Casi e Questioni cit. (nota 254 supra), pp. 70-71.

${ }^{305}$ Ver M. BESSONE, Casi e questioni cit. (nota 254 supra), p. 346.

${ }^{306}$ Ver M. BESSONE, Casi e questioni cit. (nota 254 supra), p. 415.
} 
também pessoalmente e solidariamente as pessoas que agiram em nome e por conta da $\operatorname{associação~}^{307}$.

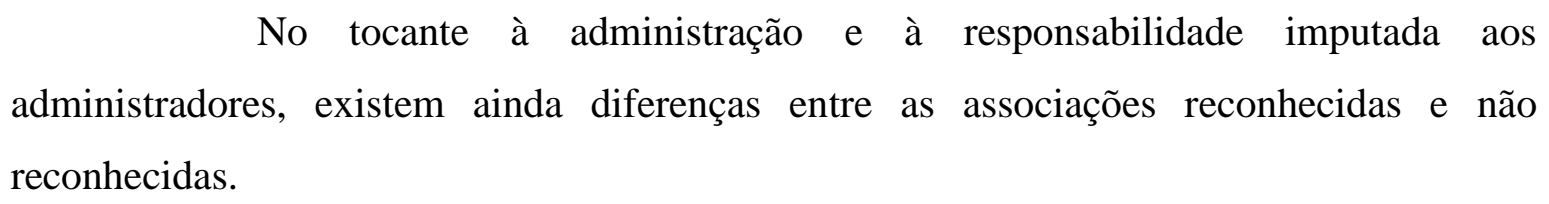

No tocante à administração e à responsabilidade imputada aos administradores, existem ainda diferenças entre as associações reconhecidas e não reconhecidas.

Aos administradores de associações reconhecidas é atribuída a natureza de mandatários do grupo. Já nas associações não reconhecidas há uma disposição que impõe aos administradores uma responsabilidade pessoal pelas obrigações da associação. Por estarem sujeitos aos riscos da administração, sustenta-se que os administradores das segundas são investidos de uma competência exclusiva para administrar. F. GALGANO defende que como são aplicadas normas das associações reconhecidas para as não reconhecidas, o inverso também pode ser feito. Desta forma, conclui que nas associações reconhecidas, assim como nas não reconhecidas, deve haver uma administração responsável, concedendo-lhe uma competência originária e exclusiva de administrar ${ }^{308}$.

A representação também é regulada de forma diversa.

Para as associações não personificadas vale a regra segundo a qual o terceiro contratante tem, em relação ao representante do ente, o ônus de acertar, de acordo com o estatuto, se o ato que está por concluir se enquadra entre aqueles que são consentidos ao representante. Para as personificadas vale a regra oposta, segundo a qual o ônus incumbe ao ente de levar a conhecimento dos terceiros eventuais limitações do poder de representação, mediante inscrição no registro das pessoas jurídicas ${ }^{309}$.

A. CARLo indaga se subsistem efetivamente critérios certos e unívocos sobre os quais se possa fundar a diferença entre um sujeito ou grupo não personificado e uma pessoa jurídica. Sendo assim, se de fato tal diferença existisse e fosse relevante para o intérprete, é necessário proceder a uma diferenciação, no âmbito do negócio associativo,

\footnotetext{
${ }^{307}$ Ver M. BESSONE, Casi e questioni cit. (nota 254 supra), pp. 430-435.

${ }^{308}$ Persone Giuridiche cit. (nota 57 supra), pp. 258-264.

${ }^{309}$ Cf. F. Galgano, Persone Giuridiche cit. (nota 57 supra), pp. 309-310. O autor explica que as limitações ao poder de representação podem consistir na proibição de executar determinados atos, ou na necessidade, para execução de determinados atos, de determinadas exigências, como assinatura conjunta de mais de um administrador ou a deliberação prévia do conselho de administração para autorizar a prática do ato. Pode haver ainda uma proibição genérica colocada pelo estatuto de praticar determinadas atividades.
} 
entre os atos constitutivos dos entes subjetivizados mas não personificados e os atos constitutivos de pessoas jurídicas ${ }^{310}$.

A personalidade jurídica é um fenômeno normativo graduável. O legislador pode distinguir entre sujeito e personalidade jurídica, estabelecendo que os primeiros possuem, em relação aos segundos, uma autonomia patrimonial mais restrita, ou uma organização interna diversa, ou ainda uma capacidade reduzida de praticar atos negociais. Contudo, parece que os critérios do legislador são em geral vagos e incertos e a criação da nova categoria não teria grande utilidade no momento que não se nega, e na verdade se postula, a aplicação analógica das normas referentes às pessoas jurídicas aos entes não personificados, por exemplo as normas de associações reconhecidas para as não reconhecidas, sempre que sejam compatíveis com a normativa ditada para aquela sede ${ }^{311}$.

O legislador italiano não disciplinou e nem previu a categoria de sujeito não reconhecido, pois sujeito e pessoa são, para eles, termos equivalentes, não se encontrando um critério estrutural certo e seguro que discrimine as associações personificadas de todos os outros entes associativos, aos quais é negada a personalidade jurídica. O autor conclui que todas as hipóteses de sujeitos coletivos examinadas constituem hipóteses de pessoas jurídicas, apesar da definição legislativa ${ }^{312}$.

Existem muitas contradições insuperáveis nas teorias com visões tradicionais do fenômeno associativo, que falam em propriedade de grupo dos entes não personificados. Para essas teorias os bens que constituem o fundo comum pertenceriam ao grupo, como ente distinto dos particulares, mas o ente não seria um sujeito nem pessoa jurídica. Afirma-se que o grupo não pode ser considerado um sujeito ou pessoa, mas quando tentam determinar a diferença entre o grupo e o sujeito, são vagos. Sustentaram que enquanto a pessoa jurídica teria a propriedade solitária dos próprios bens, o grupo não subjetivizado seria somente titular da propriedade coletiva. A diferença seria que na primeira haveria algumas limitações nos direitos da coletividade ${ }^{313}$.

O autor critica que se negue a qualificação de sujeito ao grupo. Discorda de quem sustenta que a diferença entre sujeito e pessoa seria que o primeiro possui uma autonomia patrimonial mais limitada. Contudo, considerando a autonomia patrimonial no sentido de insensibilidade do patrimônio comum às obrigações do particular, nas

\footnotetext{
${ }^{310}$ Il contratto plirilaterale cit. (nota 273 supra), p. 178.

${ }^{311}$ Ver A. CARLO, Il contratto plirilaterale cit. (nota 273 supra), pp. 178-179.

${ }^{312}$ Ver A. CARLO, Il contratto plirilaterale cit. (nota 273 supra), pp. 179-180.

${ }^{313}$ Ver A. CARLO, Il contratto plirilaterale cit. (nota 273 supra), pp. 180-181.
} 
associações não reconhecidas o credor do particular não pode agir senão apenas na quota de liquidação que cabe a este, se não for destinada a outros fins (mas não pode pedir a liquidação). O terceiro não pode interferir nas relações existentes entre outros sujeitos, a não ser nos casos previstos em lei, o que não ocorre aqui. Na sociedade anônima o sócio tem direito à sua quota na liquidação, então parece haver mais autonomia patrimonial nesse sentido, na coletividade (associação não reconhecida) ${ }^{314}$.

A. CARLO defende que o direito objetivo pode trazer limitações à capacidade de determinadas pessoas jurídicas, e não se pode excluir que a limitação da capacidade possa chegar apenas ao alcance do fim. Não existe portanto nenhuma norma que defenda que a capacidade geral da pessoa jurídica seja um elemento indispensável a ela, assim como não há nenhuma razão para sustentar que não possa existir no nosso sistema uma pessoa jurídica com capacidade relativamente limitada. Conclui que a capacidade geral de direito patrimonial não é o critério que diferencia pessoa de sujeito não personificado, uma vez que o legislador italiano não conferiu personalidade jurídica às sociedades de pessoas que possuem essa capacidade ${ }^{315}$.

Para o autor não existe diferença entre sujeito e pessoa, e o reconhecimento em si não cria nada, mas comporta o nascimento de uma pessoa jurídica enquanto determina a aplicação de uma normativa que disciplina a associação como sujeito de direito. Para haver um novo sujeito de direito deve haver um centro autônomo de imputação de relações, o que não significaria tanto autonomia patrimonial, mas o fato de que, no caso dos entes associativos, um grupo de sujeitos considerado como uma realidade distinta da soma dos particulares, se comporte como dominus nos confrontos de um complexo patrimonial - nas relações internas e externas. Não basta, para que isso ocorra, haver um interesse genérico comum, mas o legislador deve reconhecer a necessidade de se realizar tal interesse, de constituir um novo centro de imputações de relações jurídicas ${ }^{316}$.

Sendo assim, a função do reconhecimento não tem caráter constitutivo absoluto, no sentido de fazer surgir uma pessoa jurídica, e sim um caráter constitutivo relativo, no sentido de determinar a aplicação de uma normativa especial, que faz surgir uma forma especial de personalidade $\mathrm{e}^{317}$.

\footnotetext{
${ }^{314}$ Ver A. CARLO, Il contratto plirilaterale cit. (nota 273 supra), pp. 183-184.

${ }^{315}$ Il contratto plirilaterale cit. (nota 273 supra), p. 187.

${ }^{316}$ Ver A. CARLO, Il contratto plirilaterale cit. (nota 273 supra), p. 190-194.

${ }^{317}$ Ver A. CARLO, Il contratto plirilaterale cit. (nota 273 supra), p. 194.
} 
Parece que o legislador italiano confundiu e identificou dois conceitos bem diversos: autonomia patrimonial completa e titularidade do patrimônio comum, sem perceber que, por um lado, a autonomia patrimonial completa não é mais uma característica orgânica das pessoas jurídicas, e por outro lado, pode haver titularidade do patrimônio comum mesmo com uma autonomia mínima. Uma coisa é dispor como dominus de um bem, outra é responder com esse bem pelos débitos de outros sujeitos. $\mathrm{O}$ privilégio da responsabilidade limitada foi estendido pelo novo código italiano ainda que de forma não completa a alguns entes que não foram disciplinados anteriormente, independente de qualquer reconhecimento formal. Por outro lado tal privilégio foi atenuado mesmo em algumas pessoas jurídicas reconhecidas, parecendo claro que a limitação de responsabilidade não é - ou não é mais - a essência do fenômeno, e sim um atributo meramente externo e não essencial ${ }^{318}$.

A Lei francesa de 1901 também reconheceu a distinção entre as associações reconhecidas e não reconhecidas.

Estabeleceu, em seu artigo $2^{\circ}$, que as associações de pessoas podem se formar livremente, sem autorização ou declaração prévia, mas só obterão personalidade jurídica se seguirem as disposições do artigo $5^{\circ}$, ou seja, se buscarem o registro. Sendo assim, uma associação não registrada é legal, mas não possui personalidade jurídica ou patrimônio e não pode contratar ou receber subvenções, doações ou legados, nem responde civilmente, penalmente ou administrativamente ${ }^{319}$.

Os bens adquiridos por uma associação sem personalidade jurídica pertencem à propriedade indivisa de seus membros. Os contratos concluídos com o nome da associação acarretam a responsabilidade dos representantes, podendo ser os demais membros solidariamente responsáveis, se o representante estabelecer que agiram na qualidade de mandatários ${ }^{320}$.

A associação não personificada francesa possui, portanto, problemas de capacidade, que parecem ainda não superados. Y. GUYON explica, em relação às sociedades francesas, disciplina aplicável às associações, que os associados podem escolher se desejam constituir uma sociedade com personalidade jurídica ou sem, sendo

\footnotetext{
${ }^{318}$ Ver A. CARLO, Il contratto plirilaterale cit. (nota 273 supra), pp. 196-197.

${ }^{319}$ Ver S. DAMAREY et al., Code des Associations cit. (nota 34 supra), pp. 31-32.

${ }^{320}$ Ver S. DAMAREY et al., Code des Associations cit. (nota 34 supra), p. 32.
} 
que a ausência de personalidade concede a princípio uma grande liberdade, mas acarreta uma ineficácia relativa e problemas de capacidade ${ }^{321}$.

Na Alemanha, a associação irregular ou não inscrita é definida como uma união de pessoas criadas em virtude da autonomia privada, organizada corporativamente para a consecução de um fim comum, que se distingue da associação inscrita unicamente pelo fato de carecer de capacidade jurídica, ou seja, não pode ser centro de imputação autônomo de direitos e obrigações, não sendo, portanto, pessoa jurídica. F. KÜBLER ressalta que essa definição não é legal, pois a lei na verdade determina que a associação irregular deve ser considerada uma sociedade e não uma corporação ${ }^{322}$.

Existem semelhanças entre as associações personificadas e não personificadas. Ambas são criadas da mesma forma. $\mathrm{O}$ acordo adotado pelos fundadores tem caráter estatutário e não constitui um contrato de sociedade. A atuação também se dá do mesmo modo, através de seus órgãos ${ }^{323}$.

Existem também distinções, em especial no tocante à responsabilidade dos administradores ou representantes. O Código alemão estabelece que a pessoa que executa uma transação no nome da associação sem personalidade jurídica será pessoalmente responsável $^{324}$.

Para F. KÜBLER a aplicação das disposições de associações inscritas às associações irregulares não traz tanta dificuldade no âmbito interno. Os problemas surgem no âmbito das suas relações externas, porque aqui a regulação do direito das sociedades é imperativa, havendo necessidade de proteção de terceiros e do comércio jurídico de possíveis prejuízos. A titularidade do patrimônio social não é de uma corporação dotada de personalidade jurídica própria, e sim de todos os associados unidos em comum.

\footnotetext{
${ }^{321}$ Les Sociétés cit. (nota 126 supra), pp. 51-52.

${ }^{322}$ Derecho de Sociedades cit. (nota 61 supra), pp. 224-227. A aplicação desses preceitos, para o autor, traz dificuldades, em especial quando a associação possui um número grande de associados. A intenção do legislador era dificultar a criação de associações irregulares. A jurisprudência aplicou as normas da sociedade inicialmente com prudência, limitando-se continuamente, de modo a aplicar às associações irregulares cada vez mais o direito das associações, passando a ser considerada uma corporação. O Código Civil alemão expressou essa modificação, dispondo que a associação irregular também conta com uma organização corporativa, possui um poder associativo autônomo e se distingue nessa medida profundamente da sociedade. Esse regime não se aplica, contudo, a todas as associações irregulares. A associação irregular que explore uma indústria mercantil é regida pelo direito das sociedades, pois se converte em uma sociedade coletiva ao iniciar as suas atividades. Somente a associação irregular sem ânimo de lucro, cujo fim não está dirigido a uma exploração de caráter econômico, está dotada de uma organização corporativa.

${ }^{323}$ Ver F. KüBLER, Derecho de Sociedades cit. (nota 61 supra), pp. 227-228.

${ }^{324}$ Título 2, subtítulo 1, seção 54.
} 
Respondem, portanto, como devedores solidários pelas obrigações contraídas em nome da $\operatorname{associação~irregular~}^{325}$.

M. Danielian e J. I. B. Peret explicam que na Argentina as associações não personificadas serão consideradas como simples associações civis ou religiosas, segundo o fim de seu estatuto. Serão sujeitos de direito sempre que a constituição e designação de autoridades se derem por escritura pública ou instrumentos privados de autenticidade certificada por escrevente público. Se não forem, os membros fundadores da associação e seus administradores assumem responsabilidade solidária por todos os seus atos. Aplicamse subsidiariamente às associações as normas da sociedade civil ${ }^{326}$.

Concluímos, assim, que as associações não personificadas devem possuir algumas regras próprias, em especial quanto às relações externas. Contudo, seguindo o pensamento recente da doutrina italiana, o fato de não possuírem personalidade jurídica não lhes retira totalmente a capacidade de ser titulares de direitos e obrigações, mesmo necessitando de algumas regras específicas.

Entendemos que tais entidade podem ser representadas em juízo, ativa ou passivamente, pela pessoa a quem couber a administração de seus bens, da mesma forma que fazem as sociedades sem personalidade jurídica, conforme disposto no artigo 12, VII do Código de Processo Civil.

II.3. A associação como pessoa jurídica de direito privado

Se a associação inscrever o seu ato constitutivo no registro competente, adquirirá personalidade jurídica. Os efeitos da personificação serão discutidos no item seguinte. Trataremos, agora, da classificação das pessoas jurídicas de direito público e privado, sendo o objeto do presente estudo as associações que se tornam pessoas jurídicas de direito privado.

As pessoas jurídicas podem ser de direito público, interno ou externo, e de direito privado ${ }^{327}$.

\footnotetext{
${ }^{325}$ Derecho de Sociedades cit. (nota 61 supra), pp. 229-232. Para o autor não deveria, contudo, ser aplicada a responsabilidade ilimitada, respondendo os associados unicamente com o patrimônio social, e não com seu patrimônio privado.

${ }_{326}^{327}$ Personas Juridicas cit. (nota 39 supra), pp. 9-10.

${ }^{327}$ Ver artigo 40 do Código Civil brasileiro.
} 
As associações, juntamente com as sociedades, as fundações, as organizações religiosas e os partidos políticos, são pessoas jurídicas de direito privado $^{328}$.

O Código Civil italiano classifica como pessoas jurídicas de direito privado as associações, as fundações e outras instituições de caráter privado ${ }^{329}$.

O legislador brasileiro prevê que a existência legal das pessoas jurídicas de direito privado começa com a inscrição do seu ato constitutivo no respectivo registro, precedida, quando necessário, de autorização ou aprovação do Poder Executivo ${ }^{330}$.

A constituição das associações e a aquisição da personalidade jurídica já foram tratadas no item II.1.

A classificação de pessoas jurídicas em de direito público ou privado normalmente é feita de acordo com a sua constituição e objetivos que a entidade se propõe a realizar. Nesse sentido, as pessoas jurídicas de direito privado são instituídas por iniciativa privada e buscam a realização de interesses de natureza particular ${ }^{331}$.

Para outros, a classificação das pessoas jurídicas em de direito público ou privado é quanto às suas funções e capacidade ${ }^{332}$.

Contudo, como adverte J. DE O. AsCENSÃO, ao tratar da distinção entre direito público e direito privado, é inaceitável o critério do interesse, que classifica o direito público como aquele que visa à satisfação de interesses públicos e o privado à satisfação de interesses privados. Também não deve ser aceito o critério da qualidade dos sujeitos, que classifica o direito público como aquele que regula situações em que interviesse o Estado ou qualquer ente público, e o direito privado aquele que regula situações de privados. É preferível adotar o critério da posição dos sujeitos, que classifica direito público como aquele que constitui e organiza o Estado e outros entes públicos e

\footnotetext{
${ }^{328}$ Ver artigo 44 do Código Civil brasileiro.

${ }^{329}$ Ver artigo 12 do Código Civil italiano.

${ }^{330}$ Ver artigo 45 do Código Civil brasileiro.

331 Ver C. M. DA SILva PereIRA, Instituições de Direito Civil cit. (nota 22 supra), p. 215. As pessoas jurídicas de direito privado são definidas como “(...) entidades que se originam do poder criador da vontade individual, em conformidade com o direito positivo, e se propõe realizar objetivos de natureza particular, para benefício dos próprios instituidores, ou projetadas no interesse de uma parcela determinada ou indeterminada da coletividade". O autor explica que a lei considera em primeiro lugar entre elas as sociedades ou associações civis.

${ }^{332}$ Ver W. DE Barros MonTEIRO, Curso de Direito Civil cit. (nota 42 supra), p. 100.
} 
regula a sua atividade como entidade dotada de ius imperii, enquanto o direito privado é o que regula as situações em que os sujeitos estão em posição de paridade ${ }^{333}$.

Para M. M. DE SERPA LOPES o critério mais acertado para a distinção das pessoas jurídicas de direito público ou privado é o da origem. Sendo assim, as pessoas jurídicas de direito público seriam criadas por uma lei especial, ao passo que as de direito privado nascem da vontade dos sócios ou dos instituidores ${ }^{334}$.

Temos, assim, que a associação é classificada como pessoa jurídica de direito privado pelo fato de ser constituída pela vontade de particulares, os associados fundadores, para perseguir um objetivo particular, de interesse dos próprios membros ou de terceiros.

Contudo, apesar de ser uma pessoa jurídica de direito privado, as classificações não devem ser vistas como estanques, podendo uma entidade ser constituída por agentes privados para buscar interesses públicos. Muitas vezes, ainda, os fins de uma determinada comunidade podem ser vistos como particulares ou públicos, o que colabora para não se adotar a classificação de forma rígida.

Nosso estudo se dirige à análise das associações de direito privado.

\section{II.4. Efeitos da personificação}

Trataremos, agora, dos efeitos gerados pela aquisição da personalidade jurídica, adquiridos com a inscrição dos atos constitutivos da entidade no registro competente.

Nas associações, o sujeito de direito é a coletividade dos membros considerada como uma unidade distinta e independente deles. Apesar de serem frutos de uma abstração, possuem uma realidade social e jurídica. A pessoa jurídica é um ente autônomo, distinto e separado de cada membro que a compõe, que atua através de seu

\footnotetext{
${ }^{333}$ O Direito - Introdução e Teoria Geral. Uma Perspectiva Luso-Brasileira, $2^{\text {a }}$ ed. rev. e ampl., Rio de Janeiro, Renovar, 2001, pp. 346-347. O autor conclui que: "O Direito Privado não pode ser considerado como o direito dos egoísmos individuais, como o Direito Público não pode ser considerado o direito das relações de dominação. São ambos indispensáveis e entre si complementares. (...)"

${ }^{334}$ Curso de Direito Civil: Introdução, Parte Geral e Teoria dos Negócios Jurídicos, Rio de Janeiro, Freitas Bastos, 2000, pp. 365-366.
} 
representante. A vontade do representante é considerada como vontade da pessoa jurídica $^{335}$.

Os efeitos da personificação das associações são a criação de um patrimônio separado, distinto do patrimônio dos associados, transformando-se a associação em sujeito de direitos e obrigações ${ }^{336}$.

Sendo assim, a associação, assim como uma sociedade que é registrada e adquire personalidade jurídica, passa a atuar como sujeito de direitos, praticando atos e contraindo obrigações. Adquire, também, a titularidade processual, podendo demandar e ser demandada em juízo. Por fim, adquire a responsabilidade patrimonial, respondendo com o seu patrimônio pelas obrigações que assumir, patrimônio este que é distinto daquele dos $\operatorname{associados}^{337}$.

M. BASILE explica que o Código italiano de 1942 contém uma disciplina que se dirige às associações legalmente reconhecidas, com o objetivo de beneficiá-las. Com a personificação, poderiam ter os seus próprios direitos; os seus membros não teriam responsabilidade pessoal pelos débitos do ente; poderiam ser representadas pelos seus administradores na atividade jurídica e os bens comuns não poderiam ser divididos entre os associados. A disciplina protegia também os terceiros que mantivessem relações com os entes, que possuíam um patrimônio separado, e para os credores não haveria concorrência com os credores pessoais dos membros. Além disso, a personalidade trazia obrigações de publicidade, possibilitando aos terceiros interessados conhecer as condições patrimoniais e a organização interna dos entes ${ }^{338}$.

O direito confere às manifestações de interesse dos associados de criação de uma organização social consequências importantes: a assunção deste organismo ao papel de sujeito de direito e o nascimento de algumas relações no seu interior. No caso das associações, surge entre os autores do ato constitutivo um vínculo complexo de

\footnotetext{
${ }^{335}$ Cf. C. GANGI, Persone fisiche cit. (nota 283 supra), pp. 193-275. A organização de pessoas e bens é um pressuposto do nascimento da pessoa jurídica, é o elemento ou substrato material da sua constituição, enquanto o reconhecimento constitui o elemento formal.

${ }^{336}$ Ver M. H. DINIZ, Curso de Direito Civil cit. (nota 13 supra), p. 242: "Com a personificação da associação, para os efeitos jurídicos, ela passará a ter aptidão para ser sujeito de direitos e obrigações e capacidade patrimonial, constituindo seu patrimônio, que não terá relação com o dos associados, adquirindo vida própria e autônoma, não se confundindo com os seus membros, por ser uma nova unidade orgânica. Cada um dos associados constituirá uma individualidade e a associação, uma outra (Código Civil, art. 50, $2^{\mathrm{a}}$ parte), tendo cada um seus direitos, deveres e bens, apesar de não haver, nas relações entre os associados, direitos e deveres recíprocos (Código Civil, art. 53, parágrafo único).”

${ }^{337}$ Ver M. H. DiNIZ, Curso de Direito Civil cit. (nota 13 supra), p. 242-243.

${ }^{338}$ Le Persone Giuridiche cit. (nota 54 supra), pp. 16-17.
} 
colaboração - cujo conteúdo preciso varia conforme o escopo e o ordenamento da associação específica - dirigido a garantir a realização dos interesses perseguidos pelos $\operatorname{associados}^{339}$.

Assim, e com fundamento no conteúdo do código italiano, sustentou-se que a aquisição da personalidade jurídica atribui ao ente uma capacidade geral jurídica, referente aos direitos e deveres que cabem às associações, como sujeito distinto dos seus membros. Fundou-se, assim, com base em dados normativos, o princípio da distinção da pessoa jurídica em relação aos seus membros ${ }^{340}$.

Para M. BESSONE o efeito do reconhecimento em sentido formal é a criação do ente como sujeito jurídico distinto dos indivíduos que o compõem e dotado de autonomia patrimonial perfeita. Tal reconhecimento tem valor constitutivo da pessoa jurídica. Difere do reconhecimento em sentido material, consistente em um ato administrativo ou um provimento de jurisdição voluntária, ligado ao substrato substancial da pessoa jurídica ${ }^{341}$.

A Lei francesa de 1901 prevê, no seu artigo $6^{\circ}$, que todas as associações regularmente declaradas possuirão capacidade judicial, podendo receber doações e administrar as contribuições de seus membros.

O Código Civil argentino define as pessoas jurídicas como todos os entes suscetíveis de adquirir direitos ou contrair obrigações, que não são pessoas de existência visível, e sim são pessoas de existência ideal, ou pessoas jurídicas. As pessoas jurídicas são consideradas como pessoas distintas de seus membros. A sua existência começa no dia que foram autorizadas pela lei ou pelo governo, com aprovação de seus estatutos ${ }^{342}$.

F. KÜBLER explica que as associações têm um regime jurídico corporativo e necessitam de um nome para operar no tráfico jurídico e de um estatuto, no qual se fixa a sua estrutura organizativa. Quando se fala em estrutura corporativa se faz referência a uma separação estrita entre os membros isoladamente considerados e a associação. Para isso, a lei confere capacidade jurídica à corporação:, é pessoa jurídica e titular do patrimônio da entidade, inclusive das dívidas. Somente a corporação é proprietária do seu patrimônio e

\footnotetext{
${ }^{339}$ Cf. M. BASILE, Le Persone giuridiche cit. (nota 54 supra), pp. 58-59.

${ }^{340}$ Cf. M. BASILE, Le Persone giuridiche cit. (nota 54 supra), pp. 141-142.

${ }^{341}$ Casi e questioni di diritto privato cit. (nota 254 supra), p. 283.

342 Ver M. DANiElian E J. I. B. Peret, Personas Juridicas cit. (nota 39 supra), p. 9.
} 
apenas seus membros dispõem de direitos derivados de sua condição como tais, não respondendo pelas dívidas da associação ${ }^{343}$.

A associação com personalidade jurídica é uma união de pessoas criada em virtude da autonomia privada, organizada corporativamente, para a consecução de um fim comum. Surge da reunião voluntária de seus fundadores sendo a sua finalidade, regime orgânico e composição produto da autonomia privada de seus membros. A associação inscrita adquire capacidade jurídica. Como pessoa jurídica, se converte em um centro de imputação de direitos e deveres, com independência de seus membros. A consequência fundamental é que somente a associação responde pelas suas dívidas. Os credores não podem se dirigir contra o patrimônio particular dos membros da associação ${ }^{344}$.

Já mencionamos que a associação regularmente constituída possui patrimônio próprio e autônomo, distinto do patrimônio de seus associados. Consequentemente, não se admite a penhora da cota de admissão de associado em associação sem propósitos lucrativos. Justamente em razão da autonomia do patrimônio da associação em relação ao dos associados, é de se entender que a cota de admissão, também denominada "joia", uma vez satisfeita pelo pretendente a nela se congregar, despega-se do patrimônio do candidato e passa a integrar o da associação. Além disso, cabe lembrar que a contribuição sequer retorna ao patrimônio do associado em caso de dissolução da associação de intuitos não econômicos. Outro impedimento à penhorabilidade é o fato de muitos estatutos estabelecerem que a qualidade de sócio é intransmissível ${ }^{345}$.

Concluímos, assim, que os efeitos fundamentais da personificação para as associações são a aquisição de capacidade jurídica, transformando-se em sujeito de direitos e obrigações, e de autonomia patrimonial, tornando-se a associação titular de patrimônio distinto do patrimônio pessoal dos seus associados, patrimônio esse que responde pelas obrigações contraídas pela entidade.

A associação personificada é dotada de uma organização interna e os requisitos de publicidade para aquisição da personalidade jurídica protegem também os terceiros, que podem, assim, conhecer a organização interna da entidade, as condições patrimoniais e o modo de funcionamento da administração e da representação.

\footnotetext{
${ }^{343}$ Derecho cit. (nota 61 supra), pp. 62-63.

${ }^{344}$ Derecho cit. (nota 61 supra), pp. 199- 202.

${ }^{345} 1^{\circ}$ TAC-SP, $7^{\text {a }}$ Câm, Ag. n. 1124546-6, rel. Ariovaldo Santini Teodoro, j. 27-8-2002.
} 
Contudo, como já mencionado no subitem anterior, as associações não personificadas, apesar de não adquirirem personalidade jurídica, podem também ser sujeitos de direitos e obrigações, o que ocorre com outros entes não personificados, como o condomínio, o espólio, a massa falida e outros.

Enquanto para as pessoas jurídicas fala-se em autonomia patrimonial perfeita, poderíamos, para as associações não reconhecidas, cogitar de uma autonomia patrimonial imperfeita, por não haver uma completa separação entre o patrimônio desses entes e aquele de outros sujeitos.

Distinguimos, assim, entre patrimônio autônomo e separado. O primeiro é utilizado para as pessoas jurídicas enquanto o segundo destina-se aos entes não personificados - como as associações não reconhecidas - referindo-se aos bens de um sujeito destinados de forma especial - o exercício de determinada atividade - sem a criação de uma pessoa jurídica. 


\title{
NATUREZA JURÍDICA DO ATO CONSTITUTIVO QUE DÁ ORIGEM ÀS ASSOCIAÇÕES
}

\author{
Sumário: III.1. A associação como ato coletivo ou contrato plurilateral. III. 2. O contrato \\ plurilateral aberto à adesão de novos associados. A cláusula de adesão. Contratos com \\ comunhão de escopo. III.3. A associação brasileira como negócio jurídico que não é \\ contrato.
}

III.1. A associação como ato coletivo ou contrato plurilateral

A doutrina se divide no tocante à natureza jurídica do ato constitutivo das associações. Para alguns, o ato jurídico que constitui uma associação é um ato coletivo, enquanto para outros é um contrato plurilateral ${ }^{346}$.

F. C. Pontes De Miranda sustenta que o ato constitutivo não pode ser classificado como contrato, podendo o contrato conter o ato constitutivo, que é na verdade negócio jurídico, ato coletivo. A entrada como associado é também negócio jurídico, porque o novo membro adere ao que já foi negociado ${ }^{347}$.

\footnotetext{
${ }^{346}$ Segundo O. GoMes, Introdução ao Direito Civil cit. (nota 51 supra), p. 169: "Precisa a pessoa jurídica, para existir, constituir-se por ato jurídico plurilateral, quando revista a forma de associação ou de sociedade, e por ato jurídico unilateral, quando de fundação. O ato constitutivo das associações e sociedades é, para alguns, ato coletivo, e, para outros, contrato."

${ }^{347}$ Ver Tratado de Direito Privado cit. (nota 4 supra), pp. 360-361: “(...) O que se havia de criticar era a conceituação do ato constitutivo como contrato: o contrato pode contê-lo, - ele, porém, não é contrato (...) Negócio jurídico, porém não contrato; ato jurídico coletivo (Gesamtakt), criativo (...) As associações, sociedades ou fundações criadas por dois ou mais instituidores são por ato coletivo criativo. $\mathrm{O}$ autor critica aqueles que admitem que o ato constitutivo seja contrato: "Mas o engano desses juristas está em não separarem, no contrato de sociedade, o que constitui o suporte fático da pessoa jurídica. A questão não é sem interesse prático. Se o ato constitutivo fosse contrato, o descobrir-se que um dos declarantes, inclusive o subscritor de ações de uma sociedade anônima, estava incapaz ao tomar parte na constituição, expõe o ato constitutivo à decretação de nulidade, ou anulação: o art. 153, $1^{\mathrm{a}}$ parte, não salvaria o ato constitutivo. Idem, em casos de vícios da vontade. A nulidade volitiva, que há no ato coletivo, permite que se abstraia da relação entre os figurantes (A, B) e o figurante (C) incapaz ou vítima do vício da vontade (AC, BC) e se apure se, a despeito de tal exclusão, a entidade constituída existe. Também o mesmo se há de entender a propósito da falta de poderes. Se o ato coletivo é autorizativo, a incapacidade, o vício de vontade ou a falta de poderes, que não desfaça o mínimo, é inoperante. Seria bem difícil sustentar-se esse resultado, se se desse às deliberações (por maioria ou outro mínimo) o caráter de contrato. A natureza do ato coletivo é que explica poderem os figurantes tratarem, desde logo, a entidade como polo ativo de relações de crédito, com todos,
} 
A mesma posição é compartilhada por G.M. TALAVERA, para quem os estatutos que concebem as associações possuem a natureza de ato coletivo ${ }^{348}$.

Na Itália o principal defensor de que as associações deveriam se enquadrar no âmbito da categoria de ato coletivo foi MESSINEO. Com a reforma legislativa, o conceito de contrato foi modificado e melhor definido, sendo alterado de "o acordo entre dois ou mais sujeitos" para o "acordo entre duas ou mais partes". Mesmo assim, MESSINEO continuava a sustentar que os contratos de sociedade, associação e consórcio não se enquadravam no tipo previsto pelo artigo 1.420 do Código Civil italiano, mas esta posição foi criticada e se tornou isolada. BETTI também sustentou que deveria se falar em acordos, e não contratos, pela inexistência de conflito de interesses ${ }^{349}$.

M. H. DinIZ, por outro lado, defende que a associação é um contrato. Seu ato constitutivo seria formado por uma série de cláusulas vinculantes, tanto para os associados fundadores, quanto para aqueles que posteriormente ingressarem na entidade ${ }^{350}$.

\section{R. LOTUFO, que também adota a natureza contratual do ato constitutivo das} associações, especifica que a não se trata de um contrato sinalagmático, e sim um contrato "plurissubjetivo unidirecional”, contendo várias declarações de vontade no mesmo sentido, razão pela qual alguns o denominam "acordo"351.

O doutrinador de maior destaque que tratou da natureza de contratos plurilaterais das sociedades e associações foi T. ASCARELLI. Na época, a doutrina hesitava em aplicar para elas as regras dos contratos, pois normalmente, quando se tratava de sua

algum, ou alguns dos figurantes, sem se pensar em relações entre eles a favor da pessoa jurídica futura. (...) $\mathrm{O}$ ato constitutivo não dá capacidade jurídica; só a inscrição a dá. (...)”

${ }^{348}$ Das Associações, in C. E. N. CAMILlo et al (coord.), Comentários ao Código Civil, $2^{\mathrm{a}}$ ed., São Paulo, RT, 2009, p. 209. O autor, ao comentar o parágrafo único do artigo 53 do Código Civil, que dispõe não existirem, entre os associados, direitos e obrigações recíprocos, defende que: "Essa disposição elucida a ausência de contrato formalizado entre os associados para a constituição da associação, pois, ao passo que as sociedades são concebidas por meio de formalização de contratos, bilaterais ou mesmo plurilaterais, dos quais decorrem direitos e obrigações dos sócios para com a sociedade, mas também oponíveis entre si, a associação não apresenta esta característica, pois são concebidas por meio de pactos sociais denominados "estatutos", que têm natureza de ato coletivo."

${ }^{349}$ Ver A. CARLO, Il contratto plirilaterale cit. (nota 273 supra), pp. 4-5. Para o autor o contrato não pode ser considerado como um ato coletivo que exprime um escopo comum já existente. O escopo é uma consequência da estipulação do contrato e não preexiste a esse. Mesmo nesses contratos as declarações de vontade não são paralelas, como entendeu MESSINEO, e sim se cruzam. Contudo, as obrigações não se produzem entre as partes, e sim nos confrontos de um ente instrumental que surge com um patrimônio predisposto ao escopo dos sócios. O autor afasta também a posição de BETTI, explicando que o conflito de interesses parece ser característica de todos os negócios em exame.

${ }^{350}$ Cf. Curso de Direito Civil cit. (nota 13 supra), p. 240: “A associação (Verein) é um contrato pelo qual certo número de pessoas, ao se congregar, coloca, em comum, serviços, atividades, conhecimentos, em prol de um mesmo ideal, objetivando a consecução de determinado fim não econômico (Idealverein) ou econômico (wirtshafliche Verein), com ou sem capital, e sem intuitos lucrativos."

${ }^{351}$ Código Civil Comentado, vol. 1, 2ª ed., São Paulo, Saraiva, 2004, pp. 157-158. 
teoria geral, se pensava na categoria do contrato de permuta, que parecia dificilmente aplicável à associação ou à sociedade ${ }^{352}$.

De fato, algumas normas dos contratos não podiam ser aplicáveis às sociedades e associações, e outras entravam em conflito com algumas exigências práticas. A solução para tais problemas foi encontrada com a subespécie do contrato plurilateral, categoria da qual participam duas ou mais partes, decorrendo para todas elas direitos e obrigações $^{353}$.

Dessa forma, existem normas comuns aplicáveis a todos os contratos, inclusive aos aos plurilaterais, e normas próprias dos contratos de permuta, inaplicáveis aos plurilaterais $^{354}$.

As partes, nos contratos, possuem interesses contrapostos, que são solucionados pelo instrumento jurídico do contrato. No ato complexo, as partes possuem um interesse convergente, possuindo uma disciplina diversa da dos contratos. Nas sociedades e associações existe um conflito inegável de interesses na sua constituição, mas após esta fase inicial é buscado um interesse comum, o que não significa que não possa haver conflitos durante a vida das entidades. A organização interna delas visa a disciplinar estes contrastes ${ }^{355}$.

Portanto, a existência do conflito de interesses permite se falar em contrato, e a existência da comunhão de objetivo distingue este tipo do contrato de permuta ${ }^{356}$.

No mesmo sentido, A. CARLO defende que o artigo 1.420 do Código Civil italiano abarca os conflitos de interesses concernentes à constituição, modificação e extinção da relação jurídico-patrimonial entre as partes do contrato bilateral e também aqueles concernentes à criação de um ente personificado, com um escopo coletivo. Sendo assim, para haver conflito de interesses não é necessário que exista relação jurídica entre as partes, basta que uma delas aspire a uma situação de vantagem que somente possa ser realizada se lesar os interesses paralelos das outras partes ${ }^{357}$.

\footnotetext{
352 O Contrato Plurilateral, in Problemas das Sociedades Anônimas e Direito Comparado, São Paulo, Saraiva, 1945, p. 274. Por essa razão, a sociedade era vista por uma parte menor da doutrina como um ato complexo, mas a maioria continuava a sustentar que se tratava de contrato.

${ }^{353}$ T. AsCARELLI, O Contrato Plurilateral cit. (nota 352 supra), p. 275. Do ponto de vista econômico Asquini os classificava como contratos de organização.

${ }^{354}$ T. ASCARELLI, $O$ Contrato Plurilateral cit. (nota 352 supra), p. 276.

${ }^{355}$ T. AsCARELLI, $O$ Contrato Plurilateral cit. (nota 352 supra), p. 277.

${ }^{356}$ T. AsCARELLI, $O$ Contrato Plurilateral cit. (nota 352 supra), p. 278

${ }^{357}$ Il contratto plirilaterale cit. (nota 273 supra), pp. 12-14.
} 
Considerando-se as sociedades e associações como contratos, serão a elas aplicáveis a teoria geral destes, em matéria de capacidade, de vícios e do momento de sua formação. Contudo, os contratos de sociedade e de associação - subespécies dos contratos plurilaterais - possuem algumas peculiaridades ${ }^{358}$.

A primeira característica é a possibilidade de participação de duas ou mais partes, assumindo todas elas direitos e obrigações. Já nos contratos de permuta há somente duas partes, afirmando alguns que a participação de outra a mais seria incompatível com a natureza do contrato 359 .

Como dito, nos contratos plurilaterais - também denominados contratos com comunhão de fim - cada parte tem obrigações para com todas as outras. Os interesses contrastantes das várias partes devem ser unificados por meio de uma finalidade comum. Pode haver adesão sucessiva de associados ${ }^{360}$.

H. M. D. VERÇOSA define os contratos associativos - abertos ou plurilaterais - como aqueles que podem, em tese, apresentar um número ilimitado de partes. Formam-se a partir de uma vontade específica da qual as partes são imbuídas em sua celebração, conhecida pela expressão affectio societatis, que se leva a uma colaboração destinada a um fim comum, mediante a conferência de bens e de esforços. O escopo comum é a causa do contrato plurilateral $^{361}$.

O escopo é o elemento comum unificador das várias adesões, e concorre para determinar o alcance dos direitos e deveres das partes. A função do contrato plurilateral não termina quando executadas as obrigações das partes, as quais constituem, na verdade, uma premissa para uma atividade ulterior, cuja realização é a finalidade do contrato $^{362}$.

As partes de um contrato plurilateral gozam de direitos do mesmo tipo. Sua diferenciação pode ser quantitativa, mas não qualitativa. Podem ter cada uma um conteúdo diverso, sem ter um conteúdo típico constante, como em outros contratos. As prestações de cada parte não se apresentam, consideradas isoladamente, numa relação de equivalência.

\footnotetext{
${ }^{358}$ T. AsCARELLI, $O$ Contrato Plurilateral cit. (nota 352 supra), p. 284.

${ }^{359}$ T. AsCARELLI, $O$ Contrato Plurilateral cit. (nota 352 supra), pp. 285-286.

${ }^{360}$ T. AsCARELLI, $O$ Contrato Plurilateral cit. (nota 352 supra), pp. 287-290.

${ }^{361}$ Contratos Mercantis cit. (nota 74 supra), p. 81.

${ }^{362}$ T. AsCARELLI, $O$ Contrato Plurilateral cit. (nota 352 supra), p. 291.
} 
Essa relação existe, porém, entre as obrigações e os direitos de cada parte e as de todas as demais $^{363}$.

Os direitos de quem participa de uma associação e de uma sociedade são diversos. Os direitos do sócio de uma sociedade têm conteúdo típico e constante, qualquer que seja o objeto da sociedade, pois a sociedade visa à consecução de um lucro a distribuir entre os sócios. Nas associações, idêntico é o conteúdo dos direitos quanto a todos aqueles que participarem da mesma entidade, e diverso, nas várias associações ${ }^{364}$.

Os contratos plurilaterais podem ser externos ou internos, conforme deverem ou não as partes, como grupo, manter relações com terceiros para a consecução do escopo comum. Contratos abertos são aqueles que permitem uma oferta permanente de adesão a novas partes - que satisfaçam determinadas condições - e uma permanente possibilidade de desistência de quantos dele participem, sem que seja necessária a reforma do instrumento a fim de atender novas partes participantes, ou a retirada daquelas que já o integravam $^{365}$.

Outra peculiaridade dos contatos plurilaterais é referente aos vícios de constituição. Na teoria geral dos contratos, o vício de uma das manifestações de vontade vicia todo o contrato, não sendo possível a sua subsistência. O mesmo não ocorre nos contratos plurilaterais, sendo possível, à vista da pluralidade das partes, distinguir o que respeita a adesão de cada parte e o que respeita o contrato no seu conjunto. Dessa forma, anula-se a manifestação viciada, mas não contrato ${ }^{366}$.

Alguns sustentam que inexistiria uma relação sinalagmática no contrato plurilateral entre os compromissos das várias partes, pois a invalidade ou inexecução das obrigações de uma parte não excluiria a permanência do contrato entre as demais, a não ser que tornasse impossível a consecução do objetivo comum ${ }^{367}$.

M. BASILE explica que o caráter consensual e a função programática do ato constitutivo dos entes privados justificam a sua definição como negócio jurídico. Todavia, considerando que a intenção de quem o executa é dirigida ao exercício de uma atividade

\footnotetext{
${ }^{363}$ T. AsCARELli, O Contrato Plurilateral cit. (nota 352 supra), pp. 294-297.

364 T. AsCARELLI, O Contrato Plurilateral cit. (nota 352 supra), pp. 300-301.

${ }^{365}$ T. AsCARELLI, O Contrato Plurilateral cit. (nota 352 supra), pp. 301-303.

${ }^{366}$ T. ASCARELLI, O Contrato Plurilateral cit. (nota 352 supra), p. 304.

${ }^{367}$ T. AsCARELLI, O Contrato Plurilateral cit. (nota 352 supra), p. 309.
} 
coletiva própria ou alheia de acordo com a configuração do ente, a natureza de tal negócio sofre variações conforme o tipo de ente que dele surge ${ }^{368}$.

Especialmente em relação às associações houve uma grande discussão na Alemanha acerca da natureza do negócio que lhes dá origem como contrato ou como ato coletivo, com equívocos conceituais e divergências metodológicas de fundo no debate, na opinião do autor acima citado. À configuração do negócio como ato coletivo há o argumento de que com o mesmo os declarantes pré-estabelecem o alcance de um escopo comum, enquanto que no contrato os interesses dos declarantes estão, ao contrário, em conflito recíproco. Contudo, inexiste no direito privado um regime distinto dos chamados atos coletivos, e há compatibilidade com o conceito de contrato do elemento do objetivo comum - como o contrato plurilateral ${ }^{369}$.

Para M. BASILE as consequências práticas da qualificação, em termos contratuais, do ato constitutivo das associações são menores do que se imaginaria, tendo em vista que este ato se sujeita a regras gerais e especiais que prevalecem em relação aos princípios contratuais, princípios estes que são ditados essencialmente para contratos bilaterais e possuem uma aplicação restrita aos negócios que dão vida a organismos $\operatorname{associativos}^{370}$.

Sendo assim, a natureza consensual do ato constitutivo de um ente de direito privado e a presença de um componente patrimonial legitimariam a aplicação do regime geral dos contratos, seja o ato plurilateral ou unilateral. Contudo, a estrutura e a função próprias dos atos em exame comportam a coexistência de princípios que circunscrevem o âmbito da aplicação do referido regime e de normas particulares que o derrogam. A disciplina dos contratos deve ser adaptada às especificidades de cada tipo negocial, ou melhor, dos componentes das declarações. Isso vale também para os atos constitutivos dos entes $^{371}$.

Em relação aos atos constitutivos, os aspectos essenciais sob o perfil hermenêutico a serem analisados são: a sua eficácia em relação a outros sujeitos além dos originais (os novos associados, os dirigentes dos órgãos internos e aqueles que se relacionam com o ente) e sua formulação em termos muito amplos (ligada à permanência no tempo dos atos). Esses aspectos compõem a parte organizacional dos negócios, contida

\footnotetext{
${ }^{368}$ Persone giuridiche cit. (nota 54 supra), p 59.

${ }^{369}$ M. BASILE, Persone giuridiche cit. (nota 54 supra), pp. 55- 61.

${ }^{370}$ Persone giuridiche cit. (nota 54 supra), pp. 59 e 60.

${ }^{371}$ M. BASILE, Persone giuridiche cit. (nota 54 supra), pp. 60-61.
} 
em outras fontes, como os estatutos e regulamentos, que serão tratados no capítulo seguinte $^{372}$.

É difícil, porém, estabelecer em que medida os atos de exercício da autonomia coletiva, como os estatutos e regulamentos, estão submetidos à disciplina dos contratos. Para o autor, uma aplicação generalizada dessa disciplina não foi permitida pelo código italiano, porque não parece correto reconduzir ao conceito de contrato os atos dos entes que contém regras gerais e abstratas, que visam organizar a atividade necessária à satisfação dos interesses pessoais ${ }^{373}$.

Sendo assim, deve-se admitir uma aplicação limitada a esses atos da disciplina dos atos unilaterais, em especial em razão da importância do caráter da patrimonialidade para fazer tal aplicação das normas dos contratos aos atos unilaterais. $\mathrm{Na}$ ausência de outros dispositivos de lei, a aplicação se condiciona a um juízo de compatibilidade. Mesmo quando se revelar plausível a sua aplicação, serão necessárias algumas adaptações. O autor conclui que se a aplicação da disciplina dos contratos aos atos unilaterais de exercício da autonomia coletiva se tornou incontroversa, a consciência de que a correta aplicação a este tipo de ato exige diversas adaptações, também predomina ${ }^{374}$.

F. GALGANO explica que a associação é expressão da autonomia negocial, surgindo através de um negócio jurídico. Constitui-se através do contrato de associação, pois a atividade voltada a atingir o objetivo comum dos membros é a atividade executiva dos respectivos negócios constitutivos. É um negócio de organização, ou seja, negócio jurídico cuja execução implica na constituição de uma estrutura organizativa ${ }^{375}$.

$\mathrm{O}$ ato constitutivo das associações, para o autor, seria sempre um contrato, concorrendo as suas partes na administração da entidade. Normalmente na execução do contrato de associação participam as mesmas pessoas que a constituíram. A destinação do patrimônio ao escopo é objeto de uma obrigação contratual. Os membros da associação partes da relação contratual - dispõem, em relação à destinação do patrimônio da entidade, da mesma autonomia que é própria das partes de todos os contratos: podem, de livre

\footnotetext{
${ }^{372}$ M. BASILE, Le Persone giuridiche cit. (nota 54 supra), p. 61.

${ }^{373}$ M. BASILE, Le Persone giuridiche cit. (nota 54 supra), pp. 90-102.

${ }^{374}$ M. BASILE, Le Persone giuridiche cit. (nota 54 supra), pp 101-102.

${ }^{375}$ Persone giuridiche cit. (nota 57 supra), pp 68-83.
} 
arbítrio, modificar o conteúdo do contrato; deliberar sobre a dissolução da associação e, em sede de liquidação, deliberar sobre a devolução do patrimônio remanescente ${ }^{376}$.

Como a categoria do contrato plurilateral aberto contribuiu com a aceitação da doutrina italiana da ideia da origem contratual do ato constitutivo das associações, trataremos do conceito no subitem seguinte.

III.2. O contrato plurilateral aberto à adesão de novos associados. A cláusula de adesão. Contratos com comunhão de escopo

Como já mencionamos, a maior parte da doutrina, ao tratar das sociedades e das associações, defende que a sua constituição se dá através de um contrato plurilateral.

O contrato plurilateral pode ser aberto à adesão de novos associados, ou fechado.

O. GoMes tratou do contrato aberto como uma espécie de contrato plurilateral que admite o ingresso, numa relação contratual, de outros sujeitos que não as partes iniciais, como ocorre no contrato de associação ${ }^{377}$.

Como tratamos no item anterior, os contratos plurilaterais, diferentemente dos bilaterais, podem comportar mais de duas partes. Não existem interesses contrapostos, e sim convergentes. $\mathrm{Na}$ associação, assim como na sociedade, existe uma pluralidade de associados que buscam um interesse comum, sendo que a primeira se distingue da segunda em razão da finalidade perseguida não poder ser lucrativa.

T. ASCARELLI explica que na subespécie contratos plurilaterais existem várias subcategorias, sendo a do contrato de sociedade uma delas e a da associação outra. Os contratos plurilaterais são contratos com comunhão de fim, sendo o escopo o elemento comum unificador das várias adesões, e concorre para determinar o alcance dos direitos e deveres das partes ${ }^{378}$.

F. GALGANO esclarece que uma forma específica de proposta contratual é a adesão de novas partes, quando for consentida, a um contrato de troca já formado ou, mais frequentemente, plurilateral, como a adesão de novos membros a uma associação. Nos

\footnotetext{
${ }^{376}$ F. GALGANO cit. (nota 57 supra), Persone giuridiche, pp. 83-84.

${ }^{377}$ Contratos, 26 ${ }^{\mathrm{a}}$ ed., Rio de Janeiro, Forense, 2007, p. 142.

${ }^{378}$ O Contrato Plurilateral cit. (nota 352 supra), pp. 290- 291.
} 
contratos plurilaterais com estrutura aberta, a adesão de novas partes não implica em modificação do contrato originário ${ }^{379}$.

A proposta de adesão, denominada requerimento de admissão, deve ser dirigida ao órgão constituído para a atuação do contrato ou, na sua ausência, a todos os contratantes originais e, sendo dirigida à modificação subjetiva do contrato plurilateral, deve se revestir da mesma forma necessária deste. A adesão sucessiva possui, juridicamente, a mesma natureza da participação originária ao contrato. Aperfeiçoa-se, segundo os princípios gerais sobre a formação dos contratos, no momento do encontro das declarações de vontade do aderente e da associação ${ }^{380}$.

Os órgãos ou contratantes originários ficam, por sua vez, livres para aceitar ou recusar o requerimento de admissão dos novos membros, sem ter que motivar a razão da escolha, o que é um ato de autonomia contratual. A cláusula do ato constitutivo e do estatuto que prevê as condições para a admissão de novos associados tem a finalidade de tutelar os interesses dos membros atuais da associação. Dirige-se aos órgãos internos e impõe a eles que sigam, no acolhimento ou na rejeição dos requerimentos de admissão, aos critérios por ela previstos. A cláusula não se dirige, por outro lado, a terceiros e não vale como oferta contratual ao público ${ }^{381}$.

O fenômeno associativo é identificado em uma categoria contratual especial, a dos contratos com comunhão de escopo, revelando as suas características no confronto com a categoria contrária dos contratos de troca ou permuta. Nos últimos, as partes perseguem escopos contrapostos e a prestação de cada uma vai exclusivamente e diretamente de encontro à vantagem da outra, enquanto que nos contratos associativos a prestação de cada uma é preordenada para a obtenção do escopo comum a todas elas. A função do contrato não se exaure com a execução das obrigações das partes, a qual constitui, na verdade, a premissa para outra atividade, a realização da finalidade do contrato. Diferentemente dos contratos de troca, o interesse das partes só se alcança com o desenvolvimento da atividade a cujas prestações são preordenadas ${ }^{382}$.

A noção de contrato com comunhão de escopo permitiu a colocação dos fenômenos associativos no âmbito do direito dos contratos. Contudo, não existe uma disciplina unitária dos contratos com comunhão de escopo, diversa da disciplina dos

\footnotetext{
${ }^{379}$ Il negozio giuridico, $2^{\text {a }}$ ed., Milano, Guiffrè, 2002, pp. 89-90.

${ }^{380}$ Cf. F. GALGANO, Il negozio cit. (nota 379 supra), p. 90.

${ }^{381}$ F. GALGANO, Il negozio cit. (nota 379 supra), pp. 90-91.

${ }^{382}$ F. GALGANO, Il negozio cit. (nota 379 supra), pp. 201-202.
} 
contratos de troca e a eles aplicável enquanto caracterizada tal comunhão. Para construção dessa categoria, foi procedida uma generalização das características próprias das sociedades, que se revelou aplicável a essa inteira categoria ${ }^{383}$.

Contudo, se a disciplina geral dos contratos não sofre derrogações pelo simples fato de os contratantes perseguirem o mesmo escopo ao invés de objetivos contrários, questiona-se a razão de distinguir, juridicamente, entre contratos de troca e contratos de comunhão de escopo. Conclui-se que essa doutrina serviu apenas para ressaltar como o contrato, além de cumprir a sua função de compor interesses opostos, também é um instrumento idôneo para a realização de interesses comuns de diversos sujeitos. Desta forma, o contrato associativo não apresentaria elementos idôneos para diferenciá-lo de qualquer outra espécie de contrato, nem necessitaria de uma disciplina diversa daquela aplicável aos contratos de troca ${ }^{384}$.

Além disso, as figuras enquadráveis como contratos de comunhão de escopo, ao contrário de possuírem características comuns, são muito diversas entre si, especialmente em razão das diversas formas de utilização das prestações - sucessiva à sua execução por parte dos contratantes e antecedente à obtenção do resultado por eles perseguido $^{385}$.

Notaremos, porém, em algumas hipóteses, que a disciplina do contrato em geral é efetivamente derrogada e isso ocorre em relação à nulidade, que pode ser nos contratos plurilaterais em certos casos parcialmente sanada. Também em relação aos efeitos, pode-se modificar por maioria o pacto originário, o que derroga o princípio de que o contrato possui força de lei entre as partes ${ }^{386}$.

Para V. RopPo os contratos abertos se identificam normalmente com os de comunhão de escopo, no qual as partes cooperam para um interesse comum valendo-se de uma estrutura mais ou menos complexa, criada para o fim. Os principais contratos abertos são com comunhão de escopo: associações, consórcios, cooperativas. Contudo, a identificação não é perfeita, pois existem contratos com comunhão de escopo que não são abertos, como as sociedades lucrativas, e há contratos abertos sem comunhão de escopo ${ }^{387}$.

\footnotetext{
${ }^{383}$ F. GALGANO, Il negozio cit. (nota 379 supra), pp. 202-204.

${ }^{384}$ F. GALGANO, Il negozio cit. (nota 379 supra), pp. 202-204.

${ }^{385}$ F. GALGANO, Il negozio cit. (nota 379 supra), p. 206.

${ }^{386}$ Ver A. Carlo, Il contratto plirilaterale cit. (nota 273 supra), pp. 20-21.

${ }^{387}$ Il contratto, Milano, Giuffrè, 2001, p. 131.
} 
G. B. FERRI entende que a fórmula dos contratos com comunhão de escopo não é de todo própria. Para ele, em todos os contratos o escopo total é comum a todas as partes. Portanto, quando a lei fala em prestações dirigidas à obtenção de um escopo comum não se refere ao escopo contratual total, e sim a um escopo meio para realizar o interesse individual dos contratantes, ou seja, aquela atividade comum na qual se coloca a essência da sociedade e dos outros contratos associativos ${ }^{388}$.

A. CARLO distingue entre o contrato de troca e aquele com comunhão de escopo. O primeiro tem a função de constituir relações entre as partes, sendo lógico que exista uma assunção recíproca de direitos e obrigações entre as partes, enquanto o segundo tende a criar um ente coletivo, explicando-se facilmente o paralelismo das prestações dos associados dirigidas a constituir o patrimônio do próprio ente e a consequente ausência de obrigações recíprocas entre os membros ${ }^{389}$.

Nas associações as prestações dos associados compõem um fundo comum dotado das características de um patrimônio autônomo. A atividade de execução do contrato é exercida em comum pelas partes, seja mediante uma organização unitária, nas relações internas, seja através da representação unitária do grupo, nas relações externas. O vínculo associativo adquire relevância externa, quando as partes se propuserem de revelálo a terceiros 390 .

E. CESARÓ narra que atualmente se admite o princípio de considerar o negócio aberto a sujeitos tradicionalmente insensíveis aos seus efeitos, mas a experiência nesse sentido ainda é muito recente, pois a regra contratual era a limitação dos efeitos às partes, e a exceção a incidência na situação jurídica de terceiros. Buscam-se, assim, novas regras para justificar a consistência e a validade do que era exceção ${ }^{391}$.

$\mathrm{O}$ contrato aberto se conceitua como aquele que permite a adesão de outras partes, o que deverá ser comunicado a todos os contraentes originários, caso não exista, para tanto, um órgão específico. Sendo assim, a norma não indica que seja possível a

\footnotetext{
${ }^{388}$ Delle società, $2^{\text {a }}$ ed., Bologna, Nicola Zanichelli, 1968, pp. 18-65. O autor critica T. ASCARELLI por ter caído nessa imprecisão contratual quando defendeu que comunhão de escopo poderia ser entendida como o objetivo comum de dissolver uma comunhão, fazendo com que isso resulte numa afinidade entre contrato de divisão e contrato de sociedade ou associação, afinidade que para ele não subsiste.

389 Il contratto plirilaterale cit. (nota 273 supra), p. 16.

${ }^{390}$ F. GALGANO, Il negozio cit. (nota 379 supra), pp. 206-207.

${ }^{391}$ Contratto aperto e adesione del Terzo, Napoli, Jovene, 1979, pp. 4-5.
} 
adesão de terceiros, mas se limita a prever, com uma regra de valor interpretativo ou supletivo, o procedimento necessário para realizar a adesão ${ }^{392}$.

O Código Civil italiano contém no seu artigo 1.332 a disciplina acerca da adesão ao contrato plurilateral associativo. Deve haver uma igualdade de objetivos entre o aderente e os contratantes, interesses estes fundamentalmente econômicos, que podem se unir a motivos jurídicos, com base nas denominadas condições de admissão. A norma não pressupõe a formação da vontade de diversos sujeitos, mas trata da participação externa do aderente a um regulamento de interesses já constituído para outros ${ }^{393}$.

Assim, a função típica do contrato aberto em sentido estrito é aquela de individuar, de forma preventiva, uma categoria de sujeitos, aos quais se reconhece a idoneidade de compor o regulamento de interesses constituído. A cláusula de abertura desse negócio fixa os critérios de aceitação para o possível requerimento de terceiros ${ }^{394}$.

$\mathrm{O}$ autor acima citado distingue abertura em sentido amplo de restrito. Em relação à primeira, pode-se dizer que o acordo não se limita necessariamente àqueles que são contratantes no momento de sua conclusão, podendo entrar sucessivamente outros sujeitos, quando se verifique, porém, uma manifestação de vontade dos contratantes originários. Na segunda, esta vontade já existe desde o início do contrato, sendo necessária, para o ingresso de novos sujeitos, apenas a vontade deles ${ }^{395}$.

Outra distinção mencionada é aquela entre contrato aberto e contrato com estrutura aberta, sem necessidade de concordância, no qual as sucessivas adesões são elemento essencial e típico. A aplicação do chamado contrato aberto se restringiria ao fenômeno associativo ${ }^{396}$.

O conteúdo da cláusula de adesão pode ser articulado de formas diversas, de acordo com os interesses concretos a serem satisfeitos. Dois aspectos são, contudo, constantes: o primeiro refere-se às condições ou requisitos que são especificados para se atribuir uma legitimação ao sujeito interessado no ato de adesão; o outro considera o procedimento, com referência especial à individualização da competência do sujeito ao

\footnotetext{
${ }^{392}$ Ver E. CESARÓ, Contratto aperto cit. (nota 391 supra), p. 10.

${ }^{393}$ Ver E. CESARÓ, Contratto aperto cit. (nota 391 supra), p. 37. As vontades não se fundem para dar lugar a um negócio unilateral, e sim cada um assume uma posição autônoma tal a individuar centros autônomos de interesse.

${ }^{394}$ Ver E. CESARÓ, Contratto aperto cit. (nota 391 supra), pp. 41-42. A abertura a terceiros não contém um interesse indiscriminado de fazer entrar o maior número de sujeitos, mas opera através da indicação dos requisitos necessários para a adesão, ou seja, uma verdadeira escolha qualitativa de sujeitos interessados nela. ${ }^{395}$ Ver E. CESARÓ, Contratto aperto cit. (nota 391 supra), pp. 42-43.

${ }^{396}$ Ver E. CESARÓ, Contratto aperto cit. (nota 391 supra), p. 45.
} 
qual é atribuído o poder de decisão sobre o pedido de adesão, à forma, aos termos e a todas as outras modalidades que a adesão do terceiro deve observar para obter a aquisição da qualidade de associado $^{397}$.

O conteúdo da cláusula pode tratar das modalidades, requisitos e formas necessárias para a adesão. Deve haver uma especificação adequada dos requisitos subjetivos, porque devemos determinar se o exercício do poder de decisão do sujeito competente a apreciar o requerimento de adesão é livre ou não, e se a tutela do aderente possui uma base objetiva, que possa ser referida no caso de negação de adesão ${ }^{398}$.

Já o procedimento de adesão consiste na sucessão cronológica de atos necessários à formação do consenso entre associação e aderente. São normalmente dois: a cláusula de adesão considera a declaração do aderente como idônea a produzir determinadas consequências jurídicas, que consistem na extensão, para ele, das situações subjetivas derivadas às partes do contrato. Nesse caso, que é raro, o terceiro pode se considerar titular de um poder, conferido pela cláusula de adesão, que consiste na possível aquisição da qualidade de contratante, sem que seja necessário nenhum comportamento decisivo por parte do órgão ou do sujeito do contrato aberto, tanto para avaliar a existência dos eventuais requisitos do aderente, quanto para exprimir o consenso à sua participação $^{399}$.

A cláusula de adesão pode, por outro lado, prever outro procedimento, que pode ser dividido em duas fases essenciais: na primeira o terceiro pratica o ato necessário para se candidatar à admissão e na segunda existe um sujeito competente de acordo com o contrato que avalia e se pronuncia acerca da sua admissibilidade ${ }^{400}$.

Portanto, conferindo-se à cláusula de adesão um valor vinculante às partes que participam no processo de adesão, obteria-se o seguinte resultado: o terceiro, que utiliza o procedimento para aderir a um contrato associativo, pode pretender que seja respeitado pela contraparte o valor normativo da cláusula de adesão, ao qual se vincula ${ }^{401}$.

Contudo, a maioria da doutrina entende, com fundamento na autonomia privada, que o aderente não é titular de um direito subjetivo de ingressar e fazer parte do grupo associativo já constituído, quando possuir as características pessoais indicadas na cláusula de adesão e tiver observado todas as regras procedimentais previstas pela

\footnotetext{
${ }^{397}$ Ver E. CESARÓ, Contratto aperto cit. (nota 391 supra), pp. 59-60.

${ }^{398}$ Ver E. CESARÓ, Contratto aperto cit. (nota 391 supra), pp. 60-61.

${ }^{399}$ Ver E. CESARÓ, Contratto aperto cit. (nota 391 supra), pp. 69-70.

${ }^{400}$ Ver E. CESARÓ, Contratto aperto cit. (nota 391 supra), p. 70.

${ }^{401}$ Ver E. CESARÓ, Contratto aperto cit. (nota 391 supra), p. 84.
} 
associação para efetivação do ato, embora haja tentativas de dar uma resposta afirmativa, inclusive por parte da jurisprudência ${ }^{402}$.

E. Cesaró defende, porém, que o ato de decisão do sujeito competente a decidir sobre o requerimento da admissão não pode ser considerado um ato de autonomia nos limites colocados pela lei, e sim como um ato que deva levar em consideração o ordenamento interno. Diferentemente do que faz a doutrina, o ato de admissão não pode ser levado à zona da disciplina do ato pré-negocial, devendo se colocar no quadro daquela atividade que caracteriza o contrato associativo, no plano da execução ${ }^{403}$.

Poderíamos indagar se o ato de admissão do terceiro deve ter uma motivação, não se limitando a uma operação de mera conferência da presença dos requisitos exigidos pelo ato constitutivo no aderente, e se a decisão de rejeição pode ser justificada não só pela ausência desses requisitos, como também pode ser feita uma avaliação de conveniência de elementos subjetivos e objetivos ${ }^{404}$.

O autor conclui que a motivação do ato de admissão do terceiro é o critério essencial ao qual é atribuído o papel de parâmetro de julgamento para verificar se no caso concreto foram observadas as exigências objetivas, fixadas na hipótese abstrata. Alguns dizem que a motivação deve ser feita só na rejeição, não havendo necessidade dela na admissão. De fato, quando há aceitação, a necessidade de motivação é reduzida, e assim como na rejeição deve haver uma justificativa idônea e suficiente para expor as razões da recusa $^{405}$.

Pode-se, ainda, colocar um limite concreto à discricionariedade do sujeito na avaliação do interesse formalizado na regra convencional a ser aplicada na admissão do terceiro. $\mathrm{O}$ ato de admissão não pode ser identificado com as formas de exercício da autonomia privada, assumindo uma função no quadro do programa negocial, identificado no contrato associativo ${ }^{406}$.

Sendo assim, as peculiaridades do contrato bi-plurilateral associativo podem ser somente causas de uma forte autonomia em relação aos contratos de troca, mas não de uma exclusão do suporte fático geral dos contratos ${ }^{407}$.

\footnotetext{
${ }^{402}$ Ver E. CESARÓ, Contratto aperto cit. (nota 391 supra), p. 87.

${ }^{403}$ Contratto aperto cit. (nota 391 supra), p. 96.

${ }^{404}$ Ver E. CESARÓ, Contratto aperto cit. (nota 391 supra), pp. 97-99.

${ }^{405}$ Ver E. CESARÓ, Contratto aperto cit. (nota 391 supra), p. 105.

${ }^{406}$ Ver E. CESARÒ, Contratto aperto cit. (nota 391 supra), pp. 107-108.

${ }^{407}$ Ver A. CARLO, Il contratto plirilaterale cit. (nota 273 supra), pp. 294-295.
} 
Portanto, mesmo que se considere que os contratos de comunhão de escopo não possuem uma disciplina própria, a construção da categoria do contrato plurilateral aberto à adesão de novos associados ajudou na qualificação da associação como um contrato, dificuldade que era sentida pela doutrina italiana, para aplicar às sociedades e associações as regras do contrato bilateral de troca, com interesses conflitantes das partes.

III.3. A associação brasileira como negócio jurídico que não é contrato

O contrato, para F. GALgAnO, é o ato jurídico resultante do acordo entre duas ou mais partes com o objetivo de constituir, regular ou extinguir uma relação jurídica patrimonial $^{408}$.

Uma primeira dúvida surge acerca da natureza do ato constitutivo das associações, no sentido de poderem ou não ser contratos, uma vez que não constituem ou regulam, necessariamente, relações jurídicas patrimoniais e algumas associações, inclusive, podem ser constituídas sem patrimônio.

A essência do negócio jurídico está em ser uma manifestação ou declaração de vontade, explícita ou resultante de um comportamento concludente, dirigida a produzir efeitos jurídicos, que o ordenamento realiza, enquanto desejados. Na Itália o negócio jurídico não se tornou uma categoria legislativa, mas a doutrina tratou de seu conceito e aplicação, classificando-os em unilaterais, bilaterais e plurilaterais, como os contratos de associação e sociedade ${ }^{409} 410$.

M. BERNARDES DE MELLO adverte que não se pode afirmar que a declaração de vontade constitui o negócio jurídico ou que ela própria é o negócio, uma vez que tal

\footnotetext{
${ }^{408}$ Il negozio cit. (nota 379 supra), p. 3.

${ }^{409}$ F. GALGANO, Il negozio cit. (nota 379 supra), pp. 7-8.

${ }^{410}$ Ver acerca da classificação dos negócios jurídicos M. BERnARdes DE MELlo, Teoria do Fato Jurídico Plano da Existência, 9a ed., São Paulo, Saraiva, 1999, p. 173, explicando que no plano da satisfação dos interesses e carências humanas por meio de negócios jurídicos há situações (a) em que o homem sozinho pode obtê-la e (b) outras em que somente é possível alcançá-la contando com a cooperação e a concordância de outro ou outros. Existem negócios jurídicos unilaterais (que se constituem com uma única declaração de vontade), bilaterais (necessitam para existir de duas manifestações de vontade diferentes, porém recíprocas, concordantes e coincidentes, sobre o mesmo objeto) e plurilaterais (em que manifestações de vontade emanadas de mais de duas posições - lados - diferentes, mas que não são, propriamente, opostas, convergem sobre o mesmo objeto).
} 
visão elimina um elemento essencial caracterizador do fenômeno jurídico, qual seja a incidência da norma jurídica sobre o seu suporte fático ${ }^{411}$.

No mesmo sentido, A. J. DE AZEVEDO, para quem o negócio jurídico “in concreto, é todo fato jurídico consistente em declaração de vontade, a que o ordenamento jurídico atribui os efeitos designados como queridos, respeitados os pressupostos de existência, validade e eficácia impostos pela norma jurídica que sobre ele incide" ${ }^{\text {412 }}$.

Nas concepções tradicionais, como no Código Civil alemão, a relação entre negócio jurídico e contrato é de gênero a espécie: o primeiro é o gênero o segundo é uma das espécies, junto com o ato unilateral, inter vivos ou mortis causa e ato unilateral ou bilateral do direto de família. Mas muitas vezes o termo negócio jurídico é utilizado no lugar de contrato, como sinônimo ${ }^{413}$.

O negócio jurídico é uma categoria elaborada pelos pandectistas na teoria do fato jurídico, concebida em função de uma análise do sujeito de direito. A categoria de negócio jurídico como pensada pelos alemães elimina, com o máximo grau de abstração, qualquer referência possível à relação econômica. Já o legislador italiano de 1942 fez o inverso que o alemão, determinando o contrato como a categoria ordenadora.

O contrato possui no ato de troca uma referência econômica precisa. Os conceitos jurídicos adotados pelo legislador deveriam ter como ponto de referência os conceitos econômicos, mas parte da doutrina italiana continua sustentando que o negócio jurídico deve permanecer na parte geral e o contrato na parte especial do estudo do Direito Privado, como espécie de negócio jurídico ${ }^{414}$.

Por fim, no direito italiano uma parte da normativa dos contratos, aquela mais facilmente reconduzível à categoria de negócio jurídico, é abstraída da categoria dos contratos e colocada como regra geral, considerando-se o resto da disciplina dos contratos como exceção, ou espécie. Nesse sentido, quando os civilistas tradicionais italianos falam de negócio jurídico, pensam no contrato. F. GALGANO critica tais doutrinadores por não citarem todos os contratos, deixando de abordar aqueles com causa associativa, em

\footnotetext{
${ }^{411}$ Teoria do Fato Jurídico cit. (nota 410 supra), p. 147.

${ }^{412}$ Negócio Jurídico - Existência, Validade e Eficácia, 4ª ed., São Paulo, Saraiva, 2002, p. 16.

${ }^{413}$ F. GALGANO, Il negozio cit. (nota 379 supra), pp. 15-16.

${ }^{414}$ F. GAlGANO, Il negozio cit. (nota 379 supra), pp. 24-25. O contrato foi definido como o instrumento para a troca de serviços e de bens sobre os quais se baseia a produção, o meio jurídico para a concessão do crédito necessário ao incremento da produção, expressão da iniciativa privada da qual começa e se desenvolve a vida da economia.
} 
especial o contrato de sociedade. Vê-se uma contradição da ideia de negócio jurídico como categoria geral e o restrito material normativo com o qual o conceito foi construído ${ }^{415}$.

O Código Civil italiano dispõe que o contrato é o acordo entre duas ou mais partes, mencionando a modalidade plurilateral com comunhão de escopo, mas constrói a disciplina do contrato em geral com o esquema do tipo de troca. A adaptação ao contrato associativo teve que ser feita pelos intérpretes ${ }^{416}$.

Neste passo, foram atribuídas ao contrato duas funções específicas e distintas: forma de aquisição da propriedade e fonte de obrigações. Ambas são exercidas simultaneamente nos contratos translativos a título oneroso ${ }^{417} 418$.

A função regulatória do contrato para determinações abstratas, suscetíveis de aplicação repetida, é praticada de forma ampla nos contratos associativos, em especial nos estatutos das associações e das sociedades, cujas cláusulas regulam o funcionamento do ente, ou seja, a modalidade de atuação do contrato ${ }^{419}$.

H. M. D. VERÇOSA entende que existe uma separação muito clara entre o negócio jurídico (gênero) e o contrato (espécie), e a diferença entre os dois institutos estaria, precisamente, na exigência de que no contrato a relação jurídica seja de natureza patrimonial $^{420}$. A concepção latina de contrato envolve, portanto, a subjacência de uma operação econômica.

Nesse sentido, destacamos o entendimento de A. TOMASETTI JR., para quem ela - operação econômica - dá substrato aos contratos, uma vez que as partes, na sua celebração, colocam os termos daquelas que pretendem praticar. O contrato concluído produz os efeitos econômico-jurídicos próprios à operação de que tratam ${ }^{421}$.

Quando trata da causa do contrato ou do negócio jurídico em geral, o autor menciona a teoria objetiva, que a concebe como função econômico-social justificando a proteção outorgada pela ordem jurídica ${ }^{422}{ }^{423}$.

\footnotetext{
${ }^{415}$ Il negozio cit. (nota 379 supra), pp. 27-28.

${ }^{416}$ F. GALGANO, Il negozio cit. (nota 379 supra), pp. 32-33.

${ }^{417}$ Define o contrato, como já ressaltado, como o acordo entre duas ou mais partes para constituir, regular ou extinguir entre elas uma relação jurídica patrimonial.

${ }^{418}$ F. GALGANO, Il negozio cit. (nota 379 supra), p. 35.

${ }^{419}$ F. GALGANO, Il negozio cit. (nota 379 supra), p. 36.

${ }^{420}$ Contratos Mercantis cit. (nota 74 supra), p. 88.

${ }^{421}$ Execução do Contrato Preliminar, Tese (doutorado), Universidade de São Paulo, 1982, pp. 2-6 e 33. Ao tratar do contrato preliminar, o autor menciona um momento de preliminariedade mínima, que menciona ser típica ou característica para muitas das operações econômicas da sociedade capitalista atual.

${ }^{422}$ A. TOMASETTI JR., Execução do Contrato cit. (nota 421 supra), p. 09.
} 
Ao diferenciar entre execução e adimplemento das obrigações, a primeira é definida como um comportamento, um ato de uma das partes, que modifica a situação patrimonial, nas relações entre os contratantes ${ }^{424}$.

V. ROPPO também ressalta que o objeto do contrato é uma relação jurídica patrimonial. Defende que é o único gênero de relações nas quais o contrato incide, constituindo-as, regulando-as ou extinguindo-as ${ }^{425}$.

Sendo assim, a relação jurídica que o contrato constitui, regula ou extingue deve ser patrimonial, tendo como objeto coisas ou prestações pessoais suscetíveis de avaliação econômica.

Voltando à dúvida suscitada acerca do enquadramento das associações como contrato, devemos ressaltar que a área do contrato, enquanto circunscrita às relações jurídicas patrimoniais, não coincide com a esfera de interesses patrimoniais ou dos escopos econômicos. A patrimonialidade da relação não depende da natureza do interesse perseguido pelas partes - que pode ser também não patrimonial, ou seja, não econômico mas se determina em razão do fato que as prestações a que as partes estão obrigadas sejam suscetíveis de avaliação econômica ${ }^{426}$.

Portanto, o ato constitutivo das associações com escopo ideal pode ser um contrato, uma vez que as partes se obrigam com ele a executar aportes economicamente apreciáveis, enquanto a natureza não econômica dos interesses, que tais contribuições tendem a satisfazer, não influencia na natureza contratual do vínculo ${ }^{427}$.

${ }^{423}$ Ver A. J. DE AzEVEDo, Negócio Jurídico e Declaração Negocial - Noções Gerais e Formação da Declaração Negocial, tese (titularidade), Faculdade de Direito da USP, São Paulo, 1986, p. 128 acerca da causa nos negócios jurídicos, elencando os seus diversos significados: “(...) causa pode ser causa-fato jurídico (causa efficiens); causa-motivo (causa impulsiva), se motivo psicológico, e causa-justa-causa, se motivo objetivo; causa da juridicidade (civilis ou naturalis); causa da atribuição patrimonial (ou da atribuição de direitos); e causa do negócio (causa finalis com três concepções diferentes)."

${ }^{424}$ A. TOMASETTI JR., Execução do Contrato cit. (nota 421 supra), p. 38.

${ }^{425}$ Il contratto cit. (nota 387 supra), pp. 4-5.

${ }^{426}$ F. GALGANO, Il negozio cit. (nota 379 supra), pp. 38-39.

${ }^{427}$ F. GALGANO, Il negozio cit. (nota 379 supra), p. 39. O autor explica que a natureza contratual do vínculo associativo era, no passado, desconhecida. O conceito de associação parecia incompatível logicamente com o conceito de contrato: a parte do contrato, se dizia, está em contraposição de interesses com a outra parte, e as declarações de vontade de cada uma têm escopos diversos, enquanto são próprias das associações a concordância de interesses dos membros e a identidade do escopo por eles perseguidos. $\mathrm{O}$ ato constitutivo das associações era visto não como um contrato, e sim como um "ato complexo" ou "ato coletivo" idôneo a dar vista a uma pessoa jurídica o a uma instituição, posição que foi defendida inicialmente por Messineo. A concepção oposta, denominada contratualista, foi se afirmando com suporte no Código Civil, até se tornar incontestável na doutrina e jurisprudência contemporâneas, tendo inclusive Messineo mudado as suas concepções iniciais. 
Para F. Galgano o artigo 1.420 do Código Civil italiano ${ }^{428}$ toma uma posição, definido a associação como contrato plurilateral, aquele caracterizado pela participação de diversas partes, cujas prestações são destinadas à obtenção de um resultado comum $^{429}$.

A doutrina mais antiga distinguia, no interior do fenômeno associativo, um elemento contratual e um outro elemento, denominado "organizativo", que era tido como irreconduzível ao esquema do contrato. Diziam que a associação era um contrato, mas ao mesmo tempo uma pessoa jurídica, ou um sujeito de direito. Admitia-se a presença do contrato, mas limitadamente ao momento genético das sociedades e associações, assumindo os contratantes depois a posição de sócios e associados da pessoa jurídica. A orientação atual e mais aceita admite a presença do elemento contratual entre os sócios e associados após o momento genético, persistindo contrato e pessoa jurídica por todo o período de execução da relação e sendo usados, ora um ora outro, para a complexa disciplina normativa do fenômeno ${ }^{430}$.

No mesmo sentido, A. CARLO narra que alguns juristas sustentavam que os atos constitutivos das sociedades - e também as associações - eram contratos na sua origem, mas que depois se tornavam algo diferente, não podendo mais aplicar os princípios contratualísticos. Contudo, não precisavam no que o ato constitutivo se transformasse, o que demonstrava a imensa dificuldade da doutrina de aplicar às associações as normas do contrato sinalagmático ${ }^{431}$.

Para F. GALGANO a lógica contratual se manifesta com a transferência, por ato entre vivos, da qualidade de membro do grupo associativo. Se o vínculo associativo tem natureza contratual, a qualidade de membro do grupo é, por definição, a posição de

\footnotetext{
428 “Art. 1420 Nullità nel contratto plurilaterale

Nei contratti con più di due parti, in cui le prestazioni di ciascuna sono dirette al conseguimento di uno scopo comune, la nullità che colpisce il vincolo di una sola delle parti non importa nullità del contratto, salvo che la partecipazione di essa debba, secondo le circostanze, considerarsi essenziale."

${ }^{429}$ Il negozio cit. (nota 379 supra), p. 200. Concordância de interesses e identidade de escopo não são mais vistos como incompatíveis ao conceito de contrato, do qual se tende a destacar a função de instrumento técnico jurídico da colaboração econômica entre os sujeitos. O princípio de colaboração não é mais tido como estranho à natureza do contrato, pois em todos os contratos está presente um determinado tipo de colaboração, que consente de superar o conflito de interesses entre as partes. A presença de um escopo comum às partes também não é considerado um obstáculo à aplicação dos princípios sobre os contratos.

${ }^{430}$ F. GALGANO, Il negozio cit. (nota 379 supra), p. 210.

${ }^{431}$ Il contratto plirilaterale cit. (nota 273 supra), p. 5.
} 
parte de um contrato, e a cessão desta, quando consentida, não pode ser outra coisa que a cessão do contrato $^{432}$.

G. B. FERRI, da mesma forma que F. GALgano, explica que o legislador italiano de 1942 ignorou a figura do negócio jurídico, disciplinando apenas o contrato, o que não significa que o legislador tenha tido a intenção de refutar a categoria conceitual. Sendo assim, a capacidade expansiva da disciplina do contrato aos atos unilaterais entre vivos a conteúdo patrimonial ou não patrimonial, apesar das suas características estruturais (bilateralidade), faz dele uma espécie de sinônimo de negócio jurídico. Quando a doutrina teve que individuar a disciplina legislativa do instituto do negócio jurídico, acabou utilizando a disciplina do contrato, quase exclusivamente, e em especial do contrato de $\operatorname{troca}^{433}$.

Portanto, podemos dizer que quando o legislador italiano trata da associação no código, na verdade está se referindo à categoria de negócio jurídico, categoria mais ampla.

O autor também aborda as dificuldades já citadas em enquadrar a associação como um contrato, narrando que este é visto como um instrumento para regular interesses contrapostos e não paralelos, além da sua disciplina geral possuir conteúdo patrimonial. Já os negócios jurídicos podem ter conteúdo patrimonial ou não, mas sempre possuem a manifestação da autonomia privada ${ }^{434}$.

O problema da individuação do objeto nos contrato associativos é complexo. Com o contrato que dá vida à associação ou à sociedade diversas pessoas conferem bens ou serviços que vão constituir o ponto de referência patrimonial - fundo comum - o qual confere à associação ou à sociedade a possibilidade de perseguir, através do desenvolvimento de uma atividade organizada, os fins escolhidos. Nos contratos de associação, que estruturalmente pertencem à categoria de contratos plurilaterais, o interesse do particular não se realiza, como ocorre nos contratos de troca, através da prestação de

\footnotetext{
${ }^{432}$ Il negozio cit. (nota 379 supra), pp. 211-213. É importante, assim, precisar a cessão da qualidade de sócio e associado, pois com essa matéria foi afastada a tradicional distinção, no interior do fenômeno associativo, entre elemento contratual do fenômeno e aquele outro elemento, chamado "organizativo", que se entendia estranho à disciplina dos contratos. Foi admitido expressamente que os direitos administrativos dos sócios e associados, como o direito de intervir em assembleia, de votar e outros, devem ser incluídos no conteúdo do contrato de sociedade e de associação e são, por consequência, suscetíveis de ser transferidos com esse. O fenômeno associativo é caracterizado pela natureza contratual do vínculo que, tendo em vista e realização de um interesse comum, une entre eles diversos sujeitos, e pelas formas específicas de execução da relação contratual.

${ }^{433}$ Il negozio giuridico, 2a. ed., Padova, Cedam, 2009, pp. 75-83.

${ }^{434}$ Cf. G. B. FERRI, Il negozio cit. (nota 433 supra), p. 173.
} 
outro, mas pressupõe outro elemento, precisamente o desenvolvimento de uma atividade em comum, que justamente através das prestações das partes é conseguido ${ }^{435}$.

Nos contratos com estrutura associativa não existe uma relação direta entre prestação e realização do interesse individuado pelas partes. A prestação não visa realizar esse interesse, e sim fornecer os meios para a consecução daquela atividade, da qual dependerá a realização do interesse individual das partes. Nesta sequência cada elemento é conexo intrinsicamente ao outro, de forma a não permitir uma consideração dogmaticamente autônoma. Existem bens - coisas ou valores - e serviços que não têm apenas importância objetiva - como nos contratos de troca -, na dimensão específica da sua natureza, mas também, e sobretudo, importam para a destinação à atividade organizada que tinham ${ }^{436}$.

Na França a Lei de 01.07.1901, relativa ao contrato de associação, a define como a convenção pela qual duas ou mais pessoas colocam em comum, de modo permanente, seus conhecimentos ou a sua atividade, com algum objetivo diverso da distribuição dos benefícios. A associação é regida, quanto à sua validade, pelos princípios gerais de direito aplicáveis aos contratos e obrigações ${ }^{437}$.

O fundamento da associação é contratual. O contrato de associação é uma convenção regida pelo direito das obrigações, havendo liberdade de contratar e de escolher o conteúdo do contrato. Como para todas as convenções, o contrato de associação supõe o consentimento dos membros fundadores, pressupõe-se por parte dos fundadores e de todos os membros, uma contribuição de conhecimento ou de atividade visando o objetivo comum. A contrapartida ao aporte de conhecimento ou atividade é a atribuição da qualidade de associado ${ }^{438}$.

W. FLÜME explica que na Alemanha o direito comum tratou do contrato somente no direito das obrigações. A dissociação do conceito de contrato ao direito das obrigações deve ser atribuída a SAVIGNY. As normas gerais de negócio jurídico são utilizadas para a celebração do contrato, sendo este uma subcategoria do conceito geral de negócio jurídico. O conceito de contrato é uma abstração, da mesma forma que o conceito

\footnotetext{
${ }^{435}$ Cf. G. B. FERRI, Il negozio cit. (nota 433 supra), p. 173.

${ }^{436}$ Cf. G. B. FERRI, Il negozio cit. (nota 433 supra), pp. 173-175.

${ }^{437}$ Ver artigo $1^{\circ}$.

${ }^{438}$ S. DAMAREY et al., Code des Associations cit. (nota 34 supra), pp. 7-9.
} 
de negócio jurídico. Os contratantes estabelecem em comum a regulamentação negocial por meio da celebração do contrato ${ }^{439}$.

O autor adverte que os acordos não fazem parte do rol contratos, conforme defendido por A. Von TUHR, tendo em vista que por meio deles se obtém a formação de uma única vontade nas comunidades, sem importar se se trata de produção de uma vontade única em uma pessoa jurídica, ou em uma comunidade que em si não se considere pessoa. Geralmente aos acordos não é aplicável o princípio da unanimidade dos intervenientes, e sim o princípio da maioria ${ }^{440}$.

O conceito de ato coletivo foi utilizado para os casos em que de um lado da relação jurídica intervêm várias pessoas, que devem agir em comum acordo no que se refere às regras sobre relação jurídica, e para todos os casos de formação de uma vontade única em comunidades ou de constituição de comunidades. Contudo, para W. FLÜME a formação do conceito carece de importância. O mesmo vale para o conceito de convênio, tendo sido ambos utilizados pela doutrina para explicar a constituição de pessoas jurídicas. Conclui-se que atos de constituição de uma pessoa jurídica se enquadram no conceito de contrato. Na abstração do contrato, assim, estariam contidos aqueles de criação de uma $\operatorname{associação~}^{441}$.

Para F. KÜBLER o nascimento da associação se dá por etapas. Exige-se, em primeiro lugar, a fundação da entidade, ou seja, a criação da estrutura corporativa pelos fundadores, por meio de negócio jurídico. Os fundadores se obrigam reciprocamente a contribuir para a criação da associação através de um contrato pré-fundacional. Em seguida elaboram os estatutos, que devem conter a finalidade da associação. Com o acordo dos fundadores sobre os estatutos e expressada a sua vontade de ser membro, nasce a associação em formação ${ }^{442}$.

Vê-se que, a maioria da doutrina defende, atualmente, que o ato que dá origem a uma associação é um contrato, mais especificamente plurilateral, aberto à adesão de novos associados, com interesses convergentes e não contrapostos, cujas características foram tratadas no item anterior. Contudo, devemos lembrar que há diferentes empregos dos

\footnotetext{
${ }^{439}$ El Negocio Juridico, Parte General Del Derecho Civil, tomo $2^{\mathbf{o}}, 4^{\mathrm{a}}$ ed., trad. por José Maria Miquel Gonzaleze Esther Gómez Calle, Madrid, Fundación Cultural Del Notoriado, 1998, pp. 703-705.

${ }^{440}$ El Negocio Juridico cit. (nota 439 supra), pp. 706-707.

${ }^{441}$ El Negocio Juridico cit. (nota 439 supra), p. 707.

${ }^{442}$ Derecho cit. (nota 61 supra), p. 204.
} 
termos 'contrato' e 'negócio jurídico' pelos legisladores estrangeiros, tendo o italiano, por exemplo, tratado do contrato como categoria geral, no lugar do negócio jurídico.

Além das dificuldades acima citadas, para classificar a associação como contrato, existe o fato de que na associação prevista no Código Civil brasileiro não existem, entre os associados, direitos e obrigações recíprocos ${ }^{443}$.

Lembramos que T. ASCARELLI, ao tratar do contrato plurilateral, menciona que todas as partes desta modalidade de contrato são titulares de direitos e obrigações, sendo que cada parte tem obrigações para com todas as outras ${ }^{444}$.

Contudo, num contrato plurilateral, os interesses conflitantes das partes se unificam por meio de uma finalidade comum, justamente o fim perseguido pela associação.

De acordo com R. STZAJN, tratando-se de negócio associativo a natureza jurídica da constituição das associações há que partir do quadro geral dos negócios associativos a partir do qual se verificará a existência de diferença específica que as distinga de outros da mesma espécie. Tomando a noção de contrato plurilateral, definida no Código Civil italiano, a autora analisa a classificação das associações nesse tipo de negócio jurídico ${ }^{445}$.

Sendo assim, o contrato de sociedade é um contrato plurilateral, ao qual não se aplicam as regras concernentes aos contratos bilaterais ou de troca, como denominado pelo legislador italiano ${ }^{446}$.

O contrato de sociedade é um contrato de organização, entendido como determinação de um centro de imputação, de estruturação do comando, de desenho de responsabilidades e deveres dos administradores, aplicando-se a ele a disciplina do contrato plurilateral italiano. Entretanto, no que tange às associações, faltam elementos para se determinar qual o substrato deste negócio jurídico ${ }^{447}$.

Enquanto as sociedades foram inseridas na disciplina dos contratos pelo legislador brasileiro, as associações parecem ter outra natureza jurídica, pois vêm definidas

\footnotetext{
${ }^{443}$ Ver artigo 53, parágrafo único, do Código Civil.

${ }^{444}$ O Contrato Plurilateral cit. (nota 352 supra), pp. 286-287.

${ }^{445}$ Associações e sociedades, São Paulo, Revista de Direito Mercantil, ano XLI, n. 128, out./dez. 2002, p. 17.

${ }^{446}$ Associações cit. (nota 445 supra), p. 18.

${ }^{447}$ Associações cit. (nota 445 supra), p. 19.
} 
como fruto da união de pessoas que se organizam para fins não econômicos, embora admitida a aplicação supletiva das regras de sociedades para as associações ${ }^{448}$.

A autora entende, porém, que associação e sociedade são gêneros de uma mesma espécie de negócio - o associativo - e que o negócio que dá origem às associações é um contrato. Contudo, questiona a regra contida no artigo 53 do Código Civil, que disciplina que não há, entre os associados, direitos e obrigações recíprocos, concluindo que a disciplina organizativa implica na existência de vínculos, direitos, deveres e obrigações dos membros da associação em relação aos demais ${ }^{449}$.

Conclui que sociedade e associação são espécies do gênero contrato associativo. São negócios resultantes da autonomia privada, pois conteúdo patrimonial existe nos dois, pois há contribuições economicamente avaliáveis em ambos, apesar de na associação não haver distribuição de lucro entre os associados. A aplicação subsidiária das regras dispostas para as associações aos contratos de sociedade só teria lógica se o suporte negocial, no plano jurídico, fosse o mesmo. $\mathrm{O}$ ato de constituição das associações é um contrato plurilateral, enquanto que o estatuto se refere ao esquema de organização do contrato $^{450}$.

W. MORAES afasta o caráter obrigacional das uniões ditas altruístas, uma vez que a obrigação é um vínculo, no qual existe a relação débito-crédito. Na associação altruísta, porém, ninguém é credor do benefício social dentro do agrupamento, suposto exclusivamente externo o intuito operativo. Todos podem obrigar-se a contribuir com bens e serviços, mas nenhum é credor desse algo. É impossível, portanto, enxergar tal reunião como uma relação débito-crédito; como uma obrigação. Existe entre os sujeitos alguma vinculação, mas é uma coligação análoga àquela que se verifica entre coobrigados ou entre condôminos, ou cotitulares de outro direito ou situação jurídica: trata-se de simples pluralidade unilateral, cujos componentes, embora possuindo direitos e deveres entre si, não são credores e devedores obrigacionais uns dos outros. Cuida-se de uma comunidade de interesses, semelhante a uma comunhão. O consorte de uma agremiação puramente altruísta não é credor do resultado econômico da colaboração ou contraparte estipulante ${ }^{451}$.

Sendo assim, nas corporações associativas faltaria unidade sinalagmática à obrigação gerada. A associação não se constitui num sinalagma plúrimo e unitário, pois os

\footnotetext{
${ }^{448}$ Associações cit. (nota 445 supra), p. 20.

${ }^{449}$ Associações cit. (nota 445 supra), p. 25.

${ }^{450}$ Associações cit. (nota 445 supra), p. 26.

${ }^{451}$ Sociedade Civil Estrita cit. (nota 15 supra), p. 112.
} 
associados não estão todos vinculados por débitos e créditos recíprocos. $\mathrm{Na}$ verdade, comporta relações propriamente obrigacionais independentes ou justapostas, assim como vinculações bi-subjetivas dispersas ao lado de outras relações jurídicas (direitos-deveres) não obrigacionais ${ }^{452}$.

Para G. B. FERRI a obrigação de um contratante não constituiu um direito recíproco das obrigações assumidas pelos outros, e sim junto com essas o meio para o alcance do escopo comum. Será através da realização do escopo comum que cada contratante receberá a vantagem que é a reciprocidade pela obrigação assumida. Portanto a influência da obrigação de uma parte sobre o contrato inteiro, seja no momento genético, seja no funcional, não pode se determinar a não ser através do esquema do escopo comum. Para o autor o sinalagma não se coloca entre as obrigações assumidas por cada associados, mas entre as obrigações assumidas por eles e a realização do escopo comum. A contraprestação dos membros é colocada na utilidade que esses obterão na realização do escopo comum ${ }^{453}$.

Acerca da natureza do ato constitutivo que dá origem às associações, R. X. LEONARDO explica que, como não havia uma estrita separação entre associações e sociedades civis, parecia ser unânime, na doutrina, a concepção de que as associações teriam natureza jurídica contratual ${ }^{454}$.

Já no direito comparado, como já mencionado, houve uma polêmica entre duas correntes teóricas: a doutrina da associação como ato complexo e a das associações como contrato. O posicionamento que veio a se firmar foi o natureza contratual do ato constitutivo das associações em sentido estrito, através da contribuição trazida pelas noções de contrato plurilateral e contrato associativo ${ }^{455}$.

Contudo, o autor adverte que o Código Civil brasileiro não permite a pura e simples transposição do conceito de contrato plurilateral para a explicação das associações em sentido estrito, pois não há, entre os associados, direitos e obrigações recíprocos. Portanto, ou elas não se constituem por intermédio de um contrato ou o legislador incorreu em equívoco ao tentar determinar a natureza jurídica do novo instituto ${ }^{456}$.

\footnotetext{
${ }^{452}$ Ver W. MORAES, Sociedade Civil Estrita cit. (nota 15 supra), São Paulo, RT, 1987, p. 356.

${ }^{453}$ Delle società cit. (nota 388 supra), p. 18-65.

${ }^{454}$ As associações em sentido estrito no direito privado, Tese apresentada na Faculdade de Direito da Universidade de São Paulo, 2006, p. 123.

${ }^{455}$ As associações cit. (nota 454 supra), pp. 124-126.

${ }^{456}$ As associações cit. (nota 454 supra), pp. 127-128.
} 
O autor acaba afastando a disciplina dos contratos, defendendo que nas associações o substrato a ser tipificado seria corporativo. Nessas entidades, os estatutos corporificam os órgãos associativos e identificam as suas atribuições e poderes, sem estabelecer direitos e deveres correlatos entre os associados. Na extinção, o membro não é titular de uma quota e sim apenas de uma posição de pertinência ao grupo. Nenhum deles é titular de nenhuma pretensão em face dos demais associados. O descumprimento de um dever estatutário gera eficácia jurídica apenas entre a associação e o associado. A exclusão de um membro se dá mediante um procedimento interno. O patrimônio dos associados é distinto do patrimônio da entidade. Na hipótese de dissolução, o patrimônio não é repartido entre os membros ${ }^{457}$.

R. X. LeONARDo propõe como resposta para a natureza jurídica das associações em sentido estrito a verificação de um negócio jurídico organizativo, mediante o qual dois ou mais associados organizam uma entidade capaz de agir autonomamente na busca de fins não econômicos ${ }^{458}$.

Existem, logo, negócios jurídicos unilaterais, como as fundações, bilaterais e plurilaterais; como as associações. Os últimos resultam de vontades distintas que convergem para um fim comum ${ }^{459}$.

Sendo assim, e adotando esta concepção, preferimos tratar a associação no presente estudo como um negócio jurídico, organizativo ou associativo.

Isso não significa que concordemos com o afastamento da disciplina dos contratos às associações, pois como já analisado pelos doutrinadores italianos, muitas vezes falou-se em contrato pensando no negócio jurídico.

O negócio jurídico é uma categoria vista como gênero, da qual o contrato é uma de suas espécies. Ao negócio jurídico associativo e aos seus atos constitutivos e estatutos é aplicável a disciplina dos contratos, com algumas especificidades, adaptações e derrogações, de acordo com o tipo negocial.

A maioria da doutrina, estrangeira e brasileira, ainda qualifica a associação como um contrato plurilateral. Contudo, como salientou R. SzTAJN, de fato causa estranheza a regra introduzida pelo legislador brasileiro de que não existem direitos e obrigações recíprocos entre os associados, razão pela qual adotamos a denominação de

\footnotetext{
${ }^{457}$ As associações cit. (nota 454 supra), pp. 128-130.

${ }^{458}$ As associações cit. (nota 454 supra), p. 134.

${ }^{459}$ Cf. M. Bernardes DE MEllo, Teoria do Fato Jurídico cit. (nota 410 supra), pp. 174-179.
} 
negócio jurídico associativo, apesar de se entender, como analisaremos no próximo capítulo, que a ele se aplica a disciplina dos contratos e das pessoas jurídicas.

Posição contrária é defendida por A. CARLO, pois para ele o fato de inexistirem direitos e obrigações recíprocos entre os associados não afasta a aplicação da disciplina contratual. Entende que a causa do contrato plurilateral associativo é a constituição de um ente com escopo, do que derivam duas consequências: cada sócio assume as suas obrigações em relação ao ente e não aos outros associados, com os quais não possui uma relação direta; e tendo o ente uma função mas não uma obrigação de realização do escopo comum não existe para o sócio nenhum direito correspectivo pelo seu sacrifício. O sócio adimplente não pode agir contra o sócio inadimplente, como ocorre nos contratos de troca, cabendo a outro sujeito fazê-lo - a sociedade ou a associação ${ }^{460}$.

Deixamos claro, portanto, que ao estudarmos as associações de direito privado brasileiras estamos tratando de uma categoria específica de negócio jurídico, qual seja um negócio jurídico organizativo.

Uma vez constituída a relação associativa, as pretensões dos associados são dirigidas à entidade e não aos demais membros, fazendo então sentido a regra contida no artigo 53 Código Civil, de que inexistem direitos e obrigações recíprocos entre os associados.

É justamente a natureza jurídica de negócio do ato constitutivo que explica o fato dos associados possuírem relações com a entidade e não entre si ${ }^{461}$.

O interesse das partes não se realiza com a prestação das outras e sim com o desenvolvimento da atividade comum, conseguida através das prestações de cada associado.

\footnotetext{
${ }^{460}$ Il contratto plirilaterale cit. (nota 273 supra), pp. 242-245. Isso se baseia na estrutura e função dos contratos associativos e nas normas especiais referentes à exclusão. Em relação à exclusão, o seu fundamento deve ser buscado no fato de que o sócio se encontra em uma situação na qual permanecer na sociedade causaria danos ao alcance da finalidade comum (um dos casos seria o inadimplemento).Pode-se dizer que a exclusão se configura de forma mais ampla que o instituto da resolução por inadimplemento e por impossibilidade superveniente e responde à necessidade especial e própria dos entes associativos examinados de tutelar o alcance do escopo comum.

${ }^{461}$ Cf. M. BeRNARDES DE Mello, Teoria do Fato Jurídico cit. (nota 410 supra), p. 180, o negócio plurilateral é típico da constituição de sociedade. Não há relações dos sócios entre si, mas relações de cada um com o todo, a sociedade. Os direitos e deveres relacionam-se à sociedade, não com os outros sócios. As prestações e contraprestações também referem-se à sociedade, porque não há reciprocidade de direitos e deveres dos sócios entre si. Por isso que o defeito na manifestação de uma das vontades não contagia o negócio como um todo (desde que não lhe seja essencial). $\mathrm{O}$ objeto do negócio jurídico plurilateral, seja de constituição de sociedade, seja de associação ou outro ente coletivo, se consubstancia na finalidade comum: o lucro, o lazer, a prestação beneficente, a indústria, etc.
} 
A concepção latina de contrato envolve a ideia de uma operação econômica subjacente, o que pode ser aplicado para as sociedades, mas gera dúvidas em relação às associações, que não visam operações econômicas e não tratam de relações jurídicas patrimoniais.

$\mathrm{O}$ ato constitutivo das associações possui caráter consensual e função programática, pois organiza, de acordo com a vontade dos associados, a atividade necessária para satisfação dos seus interesses.

Trata-se de verdadeiro negócio de organização, cuja execução implica na constituição de uma estrutura organizativa.

A organização interna das associações será tratada no capítulo seguinte. 


\section{IV \\ ORGANIZAÇÃO INTERNA DAS ASSOCIAÇÕES}

Sumário: IV.1. Órgãos da associação: constituição, eleição, funcionamento, funções e competência. Órgãos representativos e deliberativos. Órgãos necessários e facultativos. Função disciplinar dos órgãos. IV. 2. A Assembleia: competência, convocação, instalação e tomada de deliberações. Voto e deliberação. IV.3. Deliberações nulas e anuláveis. Legitimidade para a sua impugnação Aplicação da disciplina dos contratos. IV.4. Conflito de interesses. IV.5. Órgãos administrativos. A diretoria e o conselho de administração ou supervisão. Composição, competência, funções, eleição e destituição. Tomada e impugnação de deliberações. IV.6. Responsabilidade dos administradores em face da associação, dos associados, dos credores e de terceiros. IV.7. Órgãos de controle e de resolução de controvérsias internas. IV.8. Condições para alterações do estatuto. IV.9. Direito de retirada dos associados. IV.10. Exclusão dos membros. A justa causa. Procedimento e defesa do associado. Efeitos da exclusão.

IV.1. Órgãos da associação: constituição, eleição, funcionamento, funções e competência. Órgãos representativos e deliberativos. Órgãos necessários e facultativos. Função disciplinar dos órgãos

Conforme mencionado, os associados possuem autonomia para escolher as regras que adotarão para reger a entidade, visando à obtenção da finalidade comum.

As regras dirigidas a orientar as atividades de quem desempenha funções nos entes coletivos podem ter origem interna, isto é, são frutos da autonomia que o direito garante a quem constitui o ente e a ele próprio, enquanto outras têm origem externa, derivando de atos da comunidade jurídica que legitima a entidade ${ }^{462}$.

Uma boa parte do ordenamento dos organismos sociais surgidos por iniciativa privada é fruto de autonomia, consagrada no negócio constitutivo ou em atos executados por órgãos dos entes: estatutos, regulamentos e similares. À esfera normativa de origem interna são equiparáveis as regras resultantes da prática seguida no próprio organismo. Essas normas se integram com outras vigentes na estrutura social na qual certos

462 Ver M. BASILE, Persone giuridiche cit. (nota 54 supra), pp. 90-91. As normas externas não são necessariamente inderrogáveis, havendo muitas delas de natureza dispositiva ou promocional. 
entes se inserem, sendo aplicáveis a eles, mesmo sem reenvio expresso, pelas normas internas ou externas ${ }^{463}$.

As regras, frutos de autonomia, são de várias formas condicionadas, na sua existência e em parte em seu conteúdo, pela intervenção legislativa, que submete a ônus e vínculos quem redige o ato de origem do ente ou institui os órgãos que devem aprovar o estatuto. Há uma tendência a incentivar a adoção de ordenamentos privados que respeitem alguns valores primários, com a presença de cláusulas que observem a aplicação da disciplina de favorecimento ao ente e fixando os critérios a que este deve se submeter se quiser usufruir de determinados benefícios ${ }^{464}$.

Outras vezes o legislador prescreve, de forma incondicional, alguns aspectos importantes e estabelece, de forma inderrogável, o conteúdo da disciplina referida. Nas disciplinas especiais emerge a tendência do sistema de, sobretudo, exigir ou promover a adoção, com atos de autonomia associativa, de normas de tutela da democracia interna ${ }^{465}$.

Existem distinções relevantes em relação às normas que colocam simples ônus aos autores dos ordenamentos privados e aquelas que colocam verdadeiros vínculos $^{466}$.

A primeira, não vinculante, diz respeito ao grau da obrigatoriedade. A segunda é imposta. O legislador instituiu mecanismos para garantir a observância, no exercício da autonomia, das normas, princípios e critérios por ele estabelecidos, com intervenção da autoridade administrativa ${ }^{467}$.

A tutela dos entes coletivos se dá de duas formas: da liberdade de agir da organização e através do seu reconhecimento como autor de uma série de atos executados do ponto de vista naturalístico e psicológico por pessoas físicas. A primeira baseia-se em

\footnotetext{
${ }^{463}$ Ver M. BASILE, Persone giuridiche cit. (nota 54 supra), pp. 90-91. No estatuto das associações de promoção social, por exemplo, devem estar expressamente previstos a proibição de dividir entre os associados, ainda que de forma indireta, os proveitos da atividade; a obrigação de reinvestir eventuais lucros a favor da atividade institucional estaturiamente prevista, etc.

${ }^{464}$ Ver M. BASILE, Persone giuridiche cit. (nota 54 supra), pp. 91-92.

${ }^{465}$ Ver M. BASILE, Persone giuridiche cit. (nota 54 supra), pp. 94-95. No estatuto das associações de promoção social devem estar previstas as normas do ordenamento interno inspiradas nos princípios de democracia e de igualdade dos direitos de todos os associados, com previsão de elegibilidade dos encargos associativos. Contudo, o autor adverte que normalmente falta, a nível legislativo, a indicação dos meios pelos quais se atinge a democracia interna.

${ }^{466}$ Ver M. BASILE, Persone giuridiche cit. (nota 54 supra), pp. 90-102.

${ }^{467}$ Ver M. BASILE, Persone giuridiche cit. (nota 54 supra), pp. 90-102. Para que o ente possa usufruir dos benefícios e oportunidades previstas deverá, por exemplo, se inscrever no registro público, sendo que o depositário tem a função de verificar a existência dos requisitos para tanto. Alguns atos constitutivos necessitam de autorização. Existem remédios para eventuais condutas ilegítimas das autoridades administrativas.
} 
princípios constitucionais, enquanto que a segunda se fundamenta em princípios de graus inferiores. Os organismos sociais como centros de referência de atos e atividades surgem basicamente da legislação ordinária ${ }^{468}$.

A capacidade de agir dos entes coletivos começou a ser explicada pela doutrina com a teoria da "immedesimazione organica", ou seja, superando as concepções antropomórficas das pessoas jurídicas terem, como as pessoas físicas, capacidade de agir. As relações entre a entidade e as pessoas que desenvolvem a atividade coletiva derivam de um título jurídico, que determina também a natureza da relação ${ }^{469} 470$.

Uma parte daqueles que agem é inserida nas estruturas do ente e investida de determinadas competências, constituindo os órgãos ${ }^{471}$. Normalmente existem órgãos colegiais, providos de funções deliberativas, e individuais, providos de funções executivas e de representação externa ${ }^{472}$.

A disciplina da atividade organizada se traduz na regulamentação do modo de ser e de operar dos órgãos. A finalidade é fazer com que as entidades não se desviem da perseguição dos interesses dos quais são portadoras, para perseguir objetivos estranhos ao escopo do ente, sejam eles de quem age ou de terceiros. Os órgãos não possuem autonomia

\footnotetext{
${ }^{468}$ Ver M. BASILE, Persone giuridiche cit. (nota 54 supra), pp. 205-206. Para o autor, a dificuldade de aplicação da disciplina da ação coletiva é saber em qual medida são aplicáveis a ela as normas pensadas para regular o comportamento dos indivíduos.

${ }^{469}$ Cf. C. A. DA MOTA PINTO, Teoria Geral cit. (nota 9 supra), p. 313: “(...)o vínculo entre a pessoa colectiva e as pessoas físicas que procedem em seu nome e no seu interesse deve ser caracterizado como nexo de verdadeira organicidade. A qualificação como órgãos não é uma conclusão imagética, mais ou menos arbitrária, denunciando um exagero antropomorfista no plano da conceptologia jurídica. Resulta antes dos dados normativos do sistema jurídico. (...) Logo as pessoas físicas que agem em seu nome e no seu interesse são ou integram verdadeiros órgãos e portanto as pessoas coletivas - é legítimo afirmá-lo - têm capacidade para o exercício de direitos."

${ }^{470}$ Ver M. BASILE, Persone giuridiche cit. (nota 54 supra), pp. 206-207.

${ }^{471}$ Cf. C. Bevilaqua, Código Civil cit. (nota 18 supra), p. 178: "As pessoa jurídicas são realidades do direito, porém não realidades fisiopsíquicas. Não podem agir por si, como as pessoas naturais. Necessitam de órgãos, para a sua vida de relação, que são os seus representantes, diretores e gerentes. Os órgãos da pessoa jurídica, em geral, são designados no ato que a constitui. $\mathrm{O}$ artigo fala de estatutos, como uma designação genérica, abrangendo os contratos, nas sociedades civis comuns, os compromisso das corporações e os estatutos, propriamente ditos, das associações de fins não econômicos, das sociedades anônimas e das em comandita por ações. Os representantes podem ser nomeados na própria lei orgânica da sociedade, ou pelo modo que ela indicar. Se houver omissão a respeito, entende-se que os representantes são as pessoas incumbidas de dirigir a pessoa jurídica, pois que elas é que vão dar-lhe movimento para a realização de seus fins. Na pessoa jurídica, há órgãos e representantes. Aquêles são elementos componentes da pessoa, como os sócios, a assembleia geral, as diretorias nas sociedades. Êstes são os indivíduos encarregados de cumprir as ordens dos órgãos de decisão e as resoluções dos órgãos deliberativos. Por isso mesmo, podem ser indivíduos estranhos ao conjunto orgânico da pessoa jurídica. Êste artigo fala de representantes, isto é, de indivíduos, que realizam a vontade da pessoa jurídica, tratando em nome dela, adquirindo direitos, para ela e contraindo obrigações, pelas quais ela responderá. Compreende os órgãos dirigentes e os representantes que não são órgãos."

${ }^{472}$ Ver M. BASILE, Persone giuridiche cit. (nota 54 supra), pp. 206-207.
} 
em relação à associação e constituem uma sua articulação, sendo seus atos imputados pelo direito à entidade ${ }^{473}$.

Assim como a identidade do ente não muda com a alteração dos seus membros, a dos órgãos não muda com a alteração das pessoas que os compõem. A relação orgânica comporta a imputação ao ente dos estados subjetivos em que se encontram as pessoas que compõem os órgãos e agem por ele, como o conhecimento ou ignorância de uma certa realidade, dolo ou culpa, vícios da vontade, e outros ${ }^{474}$.

As imputações dos atos às associações ocorrem desde que preenchidas as condições estabelecidas pelo direito. $\mathrm{O}$ ato ou atividade deve ter sido praticado pela pessoa física na qualidade de órgão do ente, e não a título pessoal, e deve se enquadrar nas competências atribuídas ao órgão pelo ordenamento interno ${ }^{475}$.

Uma parte das atividades dos órgãos se desenvolve no interior do ente. Essa atividade é resultado da dialética entre os interesses de quem o compõe. O legislador objetiva que sejam satisfeitos os interesses impessoais através da prevenção ou composição dos conflitos internos e com a fixação das consequências jurídicas da eventual lesão aos interesses tutelados. O sistema permite, assim, evitar que sejam concluídos procedimentos viciados ou dirigidos à prática de atos ilegítimos ${ }^{476}$.

A outra parte da atividade organizada, com função executiva, se desenvolve no exterior da entidade. Consiste em atos e prestações que determinam as relações com terceiros. A disciplina visa compor os possíveis conflitos entre os interesses das associações e de terceiros, bem como fixar as consequências jurídicas da lesão aos interesses tutelados ${ }^{477}$.

O modo de constituição e funcionamento dos órgãos deliberativos da associação, de acordo com o artigo 54 inciso V do Código Civil, deve estar previsto no seu ato constitutivo, bem como a forma da gestão administrativa e a aprovação das respectivas contas, conforme disposto no inciso VII do mesmo artigo.

\footnotetext{
${ }^{473}$ Ver M. BASILE, Persone giuridiche cit. (nota 54 supra), pp. 207-208.

${ }^{474}$ Ver M. BASILE, Persone giuridiche cit. (nota 54 supra), pp. 207-208.

${ }^{475}$ Ver M. BASILE, Persone giuridiche cit. (nota 54 supra), pp. 208-209.

${ }^{476}$ Ver M. BASILE, Persone giuridiche cit. (nota 54 supra), p. 210.

${ }^{477}$ Ver M. BASILE, Persone giuridiche cit. (nota 54 supra), p 211.
} 
Como órgãos, as associações possuem administradores, responsáveis pela sua gestão e presentação $^{478}$ e uma assembleia, cujo modo de constituição, eleição e funcionamento deverá ser estabelecido no estatuto ${ }^{479} 480481$.

${ }^{478}$ Cf. F. C. PonTES De MiRANDA, Tratado cit. (nota 4 supra), pp. 280-288 e 371, a pessoa jurídica é um conceito do mundo jurídico, sendo as teorias sobre elas perspectivas do mundo fático, que apanham parte do mundo jurídico. A pessoa jurídica seria tão real quanto a pessoa física, tendo capacidade de direito, conferida pelo sistema jurídico. Para o autor, o ato do órgão da pessoa jurídica é um ato de presentação, e não de representação da pessoa jurídica. O órgão nem representa, nem tem a posição de representante legal. Nesse sentido: "Quanto à natureza do órgão, é de afastar-se (a) que seja representante, e a teoria que o sustentou invocava o direito romano que nunca disso cogitou, nem tinha a nossa concepção de representação. (b) órgão é órgão, não é representante voluntário, nem legal: a personalidade do membro do órgão, ou do membro único, não aparece, não se leva em conta, o que não ocorreria se de representação se tratasse; o órgão atua e recebe, como o braço, a mão, a boca, ou os ouvidos humanos; o ato e a receptividade são da pessoa jurídica (F. Regelsberger, Pandekten, I, 323), porque resulta da sua organização constitucional, do seu ato constitutivo ou dos estatutos, no que órgão se distingue de empregado (E. Rhomberg, Körperschafliches Verschulden, 22). O preposto, o empregado e o estranho podem representar a pessoa jurídica, não pode funcionar como órgão, sem no ser. (...) À semelhança das pessoa físicas, as pessoas jurídicas têm o seu campo de atuação externa e o seu campo de atuação interna, conforme os seus atos são atinentes ou atingem terceiros, ou não lhes são atinentes, nem os atingem. Dentro ou para fora da pessoa jurídica, o órgão é sempre pessoa, ou grupo de pessoas, pelo qual atua a pessoa jurídica. Em vez de atuar no lugar dela, o órgão atua como órgão da pessoa jurídica, tornando-a presente, razão para conceitualmente e normativamente se deve evitar toda a alusão à "representação". O órgão da pessoa jurídica presenta-a; não a representa. (...)Introduzirse, aí, a ideia de representação é lançar-se mão da ficção, ou dilatar-se o conceito de representação.(...). Por outro lado, na vida interna, as funções administrativas dos órgãos são irredutíveis às do representante. Tanto na vida interna, quanto na externa, o órgão pode depender e depende sempre de outras vontades (e.g., a diretoria depende da assembleia geral). A ideia de representação seria, aí, ainda mais inadequada. Donde ressaltar cada vez mais a verdade da proposição: a pessoa jurídica atua por seus órgãos. Por isso, são, não só capazes de direitos, mas civil e comercialmente capazes. Não há qualquer assimilabilidade do órgão ao representante legal, nem do órgão ao representante voluntário."

${ }^{479}$ Segundo O. GOMES, Introdução ao Direito Civil cit. (nota 51 supra), p. 171: "Constituídas legalmente, podem as associações funcionar por intermédio de órgãos definidos no estatuto. São eles que praticam os atos judiciais e extrajudiciais. Os órgãos de uma associação variam conforme o que dispuser o estatuto, mas, comumente, são a assembleia geral ou um conselho deliberativo e a diretoria."

${ }^{480}$ C. A. DA MOTA PINTO, Teoria Geral cit. (nota 9 supra), p. 276, tratando do elemento organizatório das pessoas coletivas, explica que: “(...) Os órgãos da pessoa colectiva podem ser deliberativos ou executivos (representativos) e não se confundem com os agentes ou auxiliares ou com os procuradores (normalmente mandatários). A este respeito escreve : "Importa distinguir aqui os órgãos meramente deliberativos e os órgãos representativos. Os primeiros deliberam, isto é, resolvem ou decidem sobre os negócios da pessoa colectiva, mas não tratam com terceiros, nem recebem deles quaisquer declarações de vontade que hajam de produzir efeitos e relação à pessoa colectiva. Formam a vontade da pessoa colectiva, mas não a manifestam, não a projectam para o exterior. A sua actividade desenvolve-se apenas no interior da organização corporacional ou fundacional. São órgãos internos da pessoa colectiva (Innenorgane). Os segundos é que representam a pessoa colectiva nas suas relações com terceiros. Tratam com estes, emitindo ou recebendo declarações de vontade cujos efeitos se vão produzir na esfera jurídica daquela pessoa. Embora devendo cumprir as determinações dos órgãos deliberativos, são eles quem exterioriza a vontade da pessoa colectiva. Trata-se, pois, de órgãos externos ou executivos (Aussenorgane;ausführende Organe)."

${ }^{481}$ Cf. L. DA C. GoNÇALVES, Direito Civil cit. (nota 14 supra), p. 112: “(...) para exercerem a sua capacidade, isto é, exercerem os seus direitos e contraírem obrigações, as pessoas colectivas têm os seus corpos gerentes, que exprimem a vontade colectiva e são os seus representantes legais. Numas, há só uma direcção; noutras, há também assembleia geral, mas é à direcção que pertence a representação externa e a efectivação activa dos fins da pessoa colectiva; noutras existe, ainda, um conselho fiscal. Estes corpos gerentes são eleitos nos termos dos respectivos estatutos e da lei (...). As atribuições de cada corpo gerente são também indicadas no estatuto e na lei." 
F. C. Pontes de MiRAnda classifica a diretoria e a assembleia geral, nas associações, como órgãos necessários, sendo os demais, como conselho de administração, facultativos $^{482}$.

Os administradores serão eleitos de acordo com os critérios contidos no estatuto $^{483}$, que estabelecerá também a sua competência. Eles integram o denominado conselho de administração ou conselho deliberativo ${ }^{484}$.

J. E. S. PAES elenca os procedimentos que devem anteceder a assembleia geral de constituição da associação sem fins lucrativos: elaboração do estatuto, que será discutido e aprovado em assembleia; convocação dos associados ou sócios fundadores para participar da assembleia geral de constituição, cuja ordem do dia deverá ser: a constituição da sociedade; a eleição dos membros que irão compor o primeiro mandato nos órgãos internos e a definição da sede provisória; reunião em assembleia, com a lavratura de ata, contendo as seguintes deliberações: o estatuto aprovado, os membros eleitos para integrar cada órgão interno e a sede provisória da sociedade ${ }^{485}$.

$\mathrm{Na}$ administração de uma associação há, assim, pelo menos três órgãos: assembleia, diretoria e conselho fiscal. Pode haver ainda um conselho deliberativo, cujos integrantes serão escolhidos pela assembleia, sendo a ela subordinado. Normalmente a diretoria não é um órgão colegiado, mas o estatuto pode prever que algumas decisões sejam tomadas em reunião ${ }^{486}$.

\footnotetext{
${ }^{482}$ Tratado cit. (nota 4 supra), pp. 289-292 e 366: "Os órgãos ou são necessários ou facultativos. A diretoria e a assembleia geral, nas sociedades e associações, são órgãos necessários; os mais, facultativos. O órgão facultativo é a pessoa física, ou o colégio, grupo de pessoas físicas, que o ato constitutivo ou os estatutos soldaram à pessoa jurídica, tornando-o parte do organismo social. (...) Os órgãos, necessários ou facultativos, só os criam atos constitutivos e os estatutos dizem como se nomeia ou elege a pessoa ou colégio, só os atos constitutivos e estatutos dizem quais são seus poderes (poderes, dissemos; e não poder de representação). (...) Se facultativos, os atos constitutivos ou estatutos não precisam criá-los e provê-los desde logo: basta que os prevejam, e prevejam como se provêm. Se necessário, há de os ter, antes da personificação, a entidade, embora o início das funções seja a partir da personificação. (...) Quanto à determinação das funções, também o que recebe funções do órgão, e não do ato constitutivo ou dos estatutos, não é órgão. (...) A pessoa jurídica precisa ter diretoria. (...) A diretoria é que administra. Se não se diz, no ato constitutivo, quem presenta a pessoa jurídica, entende-se que é a diretoria. A diretoria e o presentante, se não é ela-mesma, expressa, na vida social, a pessoa jurídica: a relação entre a pessoa jurídica e a diretoria, ou o presentante, não é a de mandato (...), ainda que se trate de pessoa estranha ao quadro social (...). Presentante é órgão.”

${ }^{483}$ Ver o parágrafo único do artigo 59 do Código Civil.

${ }^{484}$ R. GENTIL, As Associações cit. (nota 24 supra), p. 12, explica, acerca da administração das associações: "Em quase todas as associações a administração é exercida diretamente por uma diretoria, porém compartilhada com um colegiado, às vezes denominado Conselho de Administração, outras vezes intitulado Conselho Deliberativo. Comumente, o estatuto lhes confere competência para, entre outras coisas, concretizar a peça orçamentária, autorizar os atos mais graves relativos aos bem patrimoniais, elaborar regulamentos, organizar Plano Diretor, e assim por diante."

${ }^{485}$ Fundações, Associações e Entidades cit. (nota 32 supra), p. 165.

${ }^{486}$ Cf. J. E. S. PAES, Fundações, Associações e Entidades cit. (nota 32 supra), p. 171.
} 
Ao conselho deliberativo podem ser confiadas competências para deliberar sobre a eleição dos administradores ou a exclusão dos associados; competências estas que não são privativas da assembleia. É um órgão necessariamente colegiado, integrado por três ou mais membros ${ }^{487}$.

Por fim, o conselho fiscal, órgão essencial da associação, tem como competência a fiscalização da sua gestão econômico financeira ${ }^{488}$.

F. GALGANO distingue os órgãos das associações dos das fundações, esclarecendo que as primeiras possuem órgãos dominantes, enquanto as segundas possuem órgãos servientes, vinculados à consecução do fim instituído pelo fundador ${ }^{489}$.

As atribuições dos administradores das associações encontram um limite nas competências das assembleias dos membros, uma vez que esta é chamada periodicamente a aprovar ou desaprovar os critérios de gestão adotados. Deve exprimir, com a confirmação da permanência dos dirigentes escolhidos ou com a destituição, a sua satisfação com eles e, apesar de não poder participar diretamente da administração da entidade, que é competência exclusiva do órgão administrativo, pode formular diretivas de caráter geral sobre o modo de se governar ${ }^{490}$.

O estatuto deve determinar a composição do órgão administrativo e a forma de nomeação dos seus componentes, mencionando quais deles possuem o poder de representação do ente. Qualquer outro elemento de organização deriva da aplicação de regras legais e torna desnecessárias outras disposições estatutárias. Contudo, é frequente que os estatutos formulem outras regras de organização - seja em relação ao funcionamento do órgão de gestão ou acerca das assembleias - e também criem outros órgãos, não previstos na lei: de controle, correspondentes ao conselho fiscal nas sociedades e colégios arbitrais, com a finalidade de resolver as controvérsias sobre a interpretação e aplicação do próprio estatuto ${ }^{491}$.

O órgão administrativo pode ser formado por uma só pessoa, mas o mais comum é que seja composto por uma pluralidade de pessoas, que compõem o conselho de administração e deliberam por maioria. Os administradores das associações são nomeados pela assembleia, com exceção dos primeiros, que podem já ser designados no ato

\footnotetext{
${ }^{487}$ Cf. J. E. S. PAES, Fundações, Associações e Entidades cit. (nota 32 supra), p. 177.

${ }^{488}$ Cf. J. E. S. PAES, Fundações, Associações e Entidades cit. (nota 32 supra), p. 178.

${ }^{489}$ Persone giuridiche cit. (nota 57 supra), pp. 85- 87.

${ }^{490}$ F. Galgano, Persone giuridiche cit. (nota 57 supra), pp 85-87.

${ }^{491}$ F. GAlgANO, Persone giuridiche cit. (nota 57 supra), p. 254.
} 
constitutivo. É nula a cláusula que subtrair da assembleia a nomeação ou destituição dos gestores, delegando a terceiros ou outros associados. O mesmo ocorreria com uma deliberação que determinasse tais subtrações ou delegações ${ }^{492}$.

Com relação à estrutura organizativa das associações, M. BASILE explica que o Código Civil italiano dispõe um tratamento duplo: para as associações que não aspiram à obtenção de personalidade jurídica, permite que se organizem livremente por acordos internos; para as associações reconhecidas, ao contrário, prevê a existência de um órgão assemblear e um consultivo distintos, seja por composição ou competência e colocação na estrutura organizativa. $O$ ordenamento e a administração devem ser estabelecidos nos seus atos constitutivos e estatutos ${ }^{493}$.

Além da assembleia e do conselho de administração, o ato constitutivo e o estatuto podem prever - e normalmente o fazem - outros órgãos com composição e competência especiais, subtraindo-as em parte daquelas confiadas pela lei às assembleias ou aos administradores. Trata-se de órgãos de disciplina e de justiça interna, sobre os quais surgem problemas de legitimidade e regulamentação. Recentemente têm surgido - até para as associações não reconhecidas - normas que vinculam em alguns pontos a estrutura, prescrevendo, por exemplo, órgãos de controles internos ${ }^{494}$.

A assembleia é o órgão composto por todos os associados. É permitido que o estatuto, para atender a uma necessidade de maior funcionalidade presente em fenômenos de massa, institua mais de uma delas, constituídas por delegados dos inscritos. O órgão consultivo é composto pelos administradores do ente, que não devem ser necessariamente membros. No silêncio do estatuto e do ato constitutivo, a nomeação dos dirigentes cabe à assembleia. $\mathrm{O}$ nascimento da relação de gestão pressupõe que a proposta tenha o consenso das pessoas nomeadas ${ }^{495}$.

A assembleia e o conselho de administração não são hierarquicamente semelhantes. A primeira ocupa uma posição soberana em relação ao segundo. São competências dela: a modificação do ato constitutivo e do estatuto da associação; a dissolução e a devolução do seu patrimônio; a maior parte das atividades organizativas,

\footnotetext{
${ }^{492}$ F. Galgano, Persone giuridiche cit. (nota 57 supra), pp 254-256.

${ }^{493}$ Le Persone giuridiche cit. (nota 54 supra), p. 218.

${ }^{494}$ Cf. M. BASILE, Le Persone giuridiche cit. (nota 54 supra), p. 219.

${ }^{495}$ Cf. M. BASILE, Le Persone giuridiche cit. (nota 54 supra), pp. 219-220.
} 
inclusive a exclusão dos associados; a nomeação e destituição dos administradores; os atos gerais de gestão do ente, como a aprovação do balanço ${ }^{496}$.

Ao conselho de administração compete a gestão operativa da entidade. As competências em concreto deste órgão são definidas nas normas sobre o ordenamento e a administração, previstas no ato constitutivo e no estatuto da associação; bem como em legislações especiais em relação a determinados tipos de entes. Seus poderes não se restringem à gestão dos recursos econômicos, podendo a parte operativa ser sensivelmente condicionada pelas deliberações assembleares ${ }^{497}$.

Os órgãos da associação possuem, também, uma função disciplinar, ou seja, o poder de aplicar aos membros que tenham lesado um interesse coletivo punições ou penas, como a exclusão do grupo, a perda de um direito, o pagamento de uma soma de dinheiro e outras medidas análogas ${ }^{498}$.

B. TeYssí́ explica que no direito francês deve haver, na gestão da coletividade de pessoas dotadas de personalidade jurídica, assembleias gerais, cuja competência é reunir o grupo de associados, fixando as orientações primordiais das atividades ou do grupo e tomando as decisões mais graves; um órgão restrito de deliberação, como conselho de administração, que tome decisões mais ordinárias e um presidente, que trate do funcionamento cotidiano do grupo e o represente perante terceiros $^{499}$.

Na Alemanha, como explica F. KÜBLER, as associações, diferentemente das sociedades de pessoas, contém um número grande de associados e são dotadas de uma organização corporativa, ou seja, tanto no interior quanto no exterior estão organizadas como uma unidade cuja existência não depende das circunstâncias que afetam os associados individualmente considerados, o que se traduz em algumas consequências ${ }^{500}$.

Sendo assim, a estrutura organizativa da associação, diferentemente das sociedades de pessoas, não está baseada em um contrato social, e sim nos estatutos fundacionais, dentro do marco das disposições legais. Embora ambos sejam elaborados por acordo dos membros fundadores, para a sua interpretação se aplicam regras diferentes: o contrato de sociedade regula a estrutura organizativa para o círculo, em princípio fechado,

\footnotetext{
${ }^{496}$ Cf. M. BASILE, Le Persone Giuridiche cit. (nota 54 supra), pp. 221-222.

${ }^{497}$ Cf. M. BASILE, Le Persone Giuridiche cit. (nota 54 supra), pp. 221-222.

${ }^{498}$ Cf. M. BASILE, Le Persone Giuridiche cit. (nota 54 supra), pp. 258-259.

${ }^{499}$ Droit Civil cit. (nota 38 supra), p. 335.

${ }^{500}$ Derecho de Sociedades cit. (nota 61 supra), pp. 200-201.
} 
dos sócios; a sua interpretação deve ser feita em função, fundamentalmente, da vontade subjetiva deles. Por outro lado, como na associação há uma contínua mutação de membros, os estatutos deixam de se relacionar a seus autores, passando a ter autonomia, 'vida própria', do ponto de vista jurídico. Desde este momento, o seu conteúdo deve ser interpretado unicamente em função de critérios objetivos ${ }^{501}$.

O regime orgânico corporativo implica numa estrutura organizativa complexa, na qual as competências distintas para a tomada de decisões e formação da vontade da associação estão distribuídas em vários órgãos.

Devido ao grande número de membros dessas entidades, para a formação da vontade vige o princípio da maioria. A organização corporativa independe de quem sejam os membros do ente a cada momento, sendo pensada para a mudança contínua dos associados, que podem se retirar da entidade ou ser admitidos nela sem necessidade de autorização expressa dos estatutos, ou modificação dos mesmos ${ }^{502}$.

O regime orgânico da associação, ou seja, a sua estrutura jurídica, está prevista no $\mathrm{BGB}$, que regula o estatuto dos membros e determina o funcionamento e as competências da assembleia e da diretoria, como órgãos indispensáveis para a formação da vontade e a atuação da entidade. O regime orgânico está previsto em lei e nos estatutos. Diferentemente das sociedades de pessoas, a regulação das relações internas é, em grande parte, imperativa. As disposições que se referem à convocação dos membros da assembleia não podem ser derrogadas por acordos nos estatutos ${ }^{503}$.

A assembleia dos associados constitui órgão necessário da associação. $\mathrm{O}$ BGB contém somente normas dispositivas em relação a outras questões importantes do regime orgânico. As competências da assembleia podem, então, ser reduzidas drasticamente por via estatutária. Embora haja um artigo que prevê a eleição dos membros da diretoria por este órgão, podem ser fixadas regras distintas para a nomeação, como a designação de novos membros pela própria diretoria. Em associações maiores a assembleia dos associados pode ser substituída por uma de representantes ou delegados ${ }^{504}$.

Começaremos a nossa análise com a assembleia, órgão essencial e indispensável das associações.

\footnotetext{
${ }^{501}$ Ver F. KÜBLER, Derecho de Sociedades cit. (nota 61 supra), p. 201.

${ }^{502}$ Ver F. KÜBLER, Derecho de Sociedades cit. (nota 61 supra), pp. 201-202.

${ }^{503}$ Ver F. KÜBLER, Derecho de Sociedades cit. (nota 61 supra), pp. 209-210.

${ }^{504}$ Ver F. KÜBLER, Derecho de Sociedades cit. (nota 61 supra), pp. 210-214.
} 
IV. 2. A Assembleia: competência, convocação, instalação e tomada de deliberações. Voto e deliberação

A assembleia dos associados é o principal órgão deliberativo das $\operatorname{associações~}^{505} 506$.

Compete privativamente a ela destituir os administradores, bem como alterar o estatuto social $^{507} 508$.

A assembleia deve ser, nesses casos, especialmente convocada para este fim e o estatuto deverá estabelecer o "quorum" para a tomada de tais decisões ${ }^{509} 510$.

A assembleia deverá deliberar apenas sobre o assunto objeto de sua convocação, a não ser que o estatuto permita a discussão sobre outros itens, não constantes da ordem do dia ${ }^{511}$.

As matérias de competência privativa da assembleia não podem ser delegadas a outros órgãos ${ }^{512}$.

${ }^{505}$ Cf. F. Amaral, Direito Civil cit. (nota 27 supra), p. 291: “O principal órgão deliberativo é a assembleia geral dos associados, a quem compete tomar as decisões sobre a existência, disciplina e atividade da instituição".

${ }^{506}$ Cf. F. C. Pontes De Miranda, Tratado de Direito Privado cit. (nota 4 supra), p. 384, a deliberação da assembleia é "ato coletivo, criativo, ou autorizativo, ou aprovativo (inclusive ratificativo)."

${ }^{507}$ Ver artigo 58 do Código Civil.

${ }^{508}$ Ver L. FRANÇA, Instituições de Direito Civil cit. (nota 49 supra), p. 75, acerca das alterações dos estatutos das associações: "A reforma dos estatutos, implicando numa mudança do regime de vida da entidade, deve ser deliberada igualmente conforme as disposições estatutárias (art. 19, III). No silêncio destas, é óbvio que só a assembleia dos sócios poderá decidi-la. Para a decisão cumprirá distinguir se a matéria é de somenos importância (número de membros da diretoria, criação de novos órgãos, etc.) No primeiro caso bastará a maioria absoluta, mas no segundo a decisão deve ser pela unanimidade dos sócios."

${ }^{509}$ Ver o parágrafo único do artigo 59 do Código Civil.

${ }^{510}$ Ver C. R. GonÇALves, Curso de Direito Civil cit. (nota 80 supra), p. 202, acerca do quorum para a tomada de deliberações cuja matéria é competência privativa da assembleia geral, dispostas no artigo 59 do Código Civil: "Tal regramento provocou enorme polêmica entre os interessados, pois fazia distinções que não existiam no Código de 1916. Este dizia que a assembleias poderiam deliberar por maioria de votos entre os presentes. Já a nova lei exigia, para a destituição de administradores e alterações de estatuto, a presença da maioria absoluta dos associados para deliberação em primeira convocação, e de um terço dos associados nas convocações seguintes, com aprovação por dois terços dos presentes.” A Lei 11127 de 2005 eliminou tais quoruns, sendo a redação atual do artigo citado que o quorum para deliberações que envolvam a destituição de administradores e a reforma do estatuto deve ser estabelecidos no estatuto.

${ }^{511}$ F. C. PONTES De MiRANDA, Tratado de Direito Privado cit. (nota 4 supra), p. 381.

${ }^{512}$ Cf. F. U. Coelho, Curso de Direito Civil cit. (nota 10 supra), p. 252: "A alteração do estatuto e a destituição dos administradores, são matérias que, em vista de sua enorme importância, só a assembleia geral tem competência pra votar. Nenhum estatuto de associação pode atribuir a apreciação de tais matérias a outro órgão deliberativo, como o conselho de administração ou consultivo, por exemplo." 
O. GOMES explica que o estatuto regula os direitos e deveres dos associados, contendo preceitos jurídicos de direito corporativo, adotando o princípio básico de que as deliberações devam ser tomadas por maioria ${ }^{513}$.

Segundo V. ROPPO o voto é o paradigma da manifestação da vontade do componente do grupo visando ao interesse comum. É um ano unilateral. Já a deliberação é o resultado determinado do concurso dos votos. Uma vez formada, dispõe do interesse comum $^{514}$.

O estatuto pode estabelecer, contudo, que algumas delas sejam aprovadas somente por unanimidade 515516 .

Sendo assim, as deliberações são tomadas por maioria simples, exceto se o estatuto dispuser de modo contrário. Os associados dissidentes poderão se retirar da associação.

O estatuto estabelecerá, ainda, a forma de convocação das assembleias, das quais participam todos os associados, garantindo a 1/5 (um quinto) deles o direito de promovê-la ${ }^{517}$.

F. C. PONTES DE MiRAndA explica que a convocação deve ser feita pela diretoria, salvo se o ato constitutivo determinar outro órgão. Se não for efetuada dessa forma, poderá ainda ser realizada por um quinto dos associados ${ }^{518}$.

${ }^{513}$ Introdução ao Direito Civil cit, (nota 51 supra), p. 171. Para o autor, se não houvesse a norma de tomada de deliberações pela maioria dos associados, seria impossível o funcionamento das associações. Adverte, contudo, que: “(...) embora se reconheça a sua necessidade, a conveniência de se resguardar a liberdade individual impõe medidas tendentes a estabelecer limitações ao poder deliberativo dos que preponderam numericamente."

514 Il contratto cit. (nota 387 supra), pp. 33-34. Para o autor, a deliberação não é um contrato.

${ }^{515}$ Cf. F. U. CoElho, Curso de Direito Civil cit. (nota 10 supra), p. 247, a regra, na formação da vontade da pessoa jurídica é a aplicação do princípio majoritário, correspondendo a vontade da pessoa jurídica à vontade da maioria dos membros do órgão deliberativo. O autor exemplifica da seguinte forma: "Se a maioria dos associados presentes à assembleia do clube aprova o aumento da contribuição associativa, esta passa a ser a vontade da pessoa jurídica, à qual se submetem os demais associados." O autor ressalta, ainda, que o estatuto pode limitar a predominância da vontade da maioria, estabelecendo que determinadas deliberações sejam tomadas por unanimidade, ou ainda atribuindo o poder de veto.

${ }^{516}$ M. H. Diniz, Curso de Direito Civil cit. (nota 13 supra), p. 254, adverte que: “Apesar de seus vastos poderes, a assembleia não poderá efetivar todas as deliberações da maioria, uma vez que há certos direitos essenciais dos associados, oriundos do pacto social, insuscetíveis de violação. Nenhum órgão deliberativo poderá cercear, arbitrariamente, direitos próprios dos associados, oriundos do pacto social, insuscetíveis de violação."

${ }^{517}$ Ver o artigo 60 do Código Civil.

${ }^{518}$ Tratado de Direito Privado cit. (nota 4 supra), p. 381. A forma de convocação deve ser estabelecida pelo estatuto, e, na sua omissão, pode ser feita de qualquer forma e num prazo de antecedência razoável, sob pena de nulidade das deliberações. 
Se a assembleia possui a competência de destituir os administradores, deve, também, elegê-los ${ }^{519}$. O conselho de administração, por sua vez, pode eleger a diretoria, órgão executivo da associação.

Já para M. REALE a eleição dos administradores, quais sejam, os dirigentes da associação - diretores ou conselheiros - deve ser efetuada pela assembleia geral, restando proibida a eleição por outro órgão. Contudo, o autor admite a possibilidade dos diretores serem eleitos pelo Conselho ${ }^{520} 521$.

A primeira assembleia de uma associação deverá ser justamente aquela que determina a sua constituição, com a votação e aprovação do estatuto. Deverá ser composta pelos associados que possam votar, pois pode ocorrer que alguns deles sejam impedidos de fazê-lo em razão do não pagamento de alguma contribuição.

A princípio todos os membros possuem o direito de votar nas assembleias gerais. Contudo, como adverte W. DE BARRos MonTEIRO, apesar do direito de voto ser inerente à qualidade de associado, o estatuto pode estabelecer o modo de exercê-lo ${ }^{522}$.

O direito de voto, em razão de sua importância, é, segundo Y. GuYON, de ordem pública. Em casos excepcionais, pode ser suprimido, como quando um sócio não

\footnotetext{
519 Cf. C. R. Gonçalves, Curso de Direito Civil cit. (nota 80 supra), p. 203: "Parecia razoável o entendimento de que o denominado Conselho de Administração, do qual emanam as diretrizes básicas atinentes à administração e às decisões fundamentais, fosse eleito pela assembleia geral. Todavia, quando se tratasse de apontar aqueles que seriam encarregados de executar os atos, seria lícito que a individualização pertencesse ao conselho e desde que a escolha ficasse restrita entre os que o compõem. (...) Tal entendimento foi acolhido pelo Tribunal de Justiça de São Paulo nestes termos: "o art. 59 do novo Código Civil não leva à convicção certa e induvidosa de que a eleição dos dirigentes de associações e clubes desportivos, em assembleia geral, respeitados os princípios constitucionais da autonomia da organização e fundamento (art. 217, I, CF) e da liberdade de associação (art. $5^{\circ}, \mathrm{XVIII}, \mathrm{CF}$ ), só possa ser a direta, pelos próprios sócios, e não a indireta, em dois ou mais pleitos."

${ }^{520}$ As Associações no Novo Código Civil, Informativo Incijur, n. 45, abril 2003, p.1: "Em primeiro lugar, cabe esclarecer que a palavra administradores é empregada no sentido de dirigentes, qualquer que seja a expressão usada no estatuto social, como, por exemplo, a de diretores ou conselheiros. (...) A questão mais delicada se refere à eleição dos dirigentes pela assembleia geral, porquanto se configuram várias hipóteses à luz do estatuto social, devendo-se considera, desde logo, proibida a eleição por outro órgão que não seja a assembleia geral, como, por exemplo, os associados fundadores. Isto posto, todavia, não procede o entendimento que a escolha deva sempre ser feita de uma só vez e para a totalidade dos cargos a serem preenchidos, podendo o estatuto prever a eleição em períodos distintos, de um ou mais anos, com renovação periódica e parcial do mandato dos diretores. Não é dito, assim, que os cargos que compõem a diretoria da associação devam ser eleitos pela assembleia geral, para cada um deles, podendo o estatuto social estabelecer a escolha por ela de todos os componentes de um Conselho, cabendo a este, depois, a designação, dentre os seus membros, dos titulares dos cargos de direção."

${ }^{521}$ Ver também o entendimento de R. GENTIL, As Associações cit. (nota 24 supra), p. 12: "Nesses casos, quando emanam de um conselho as diretrizes atinentes à administração e as decisões fundamentais, os seus integrantes agem como administradores. Como tais, é imperativo da lei que sejam eleitos pela assembleia geral. Todavia, quando se trata de apontar aqueles que serão encarregados de executar os atos, é lícito que a individualização seja do conselho e desde que a escolha fique restrita entre os que o compõem."

${ }^{522}$ Curso de Direito Civil cit. (nota 42 supra), p. 153.
} 
fizer os seus aportes nas sociedades e quando um associado não prestar alguma contribuição à qual estava obrigado nas associações ${ }^{523}$.

A assembleia das associações deve ser convocada pelos administradores para aprovação do balanço uma vez por ano, bem como quando houver necessidade, ou se for feita solicitação de pelo menos um quinto dos associados. O requerimento deve ser motivado e será submetido à apreciação dos administradores acerca da necessidade da convocação, a qual, se não for aceita, poderá ser levada ao poder judiciário pelos membros insatisfeitos com a recusa dos gestores ${ }^{524}$.

Na Itália, as deliberações da assembleia são tomadas por maioria dos votos e com presença de pelo menos metade dos associados. Já na segunda convocação, a deliberação será válida com qualquer número de membros. Os administradores não devem votar nas deliberações de aprovação do balanço e naquelas referentes à sua responsabilidade ${ }^{525}$.

Alguns quoruns especiais são exigidos para aprovação de determinadas matérias, como a modificação do ato constitutivo e do estatuto, sendo necessária, se o estatuto não contiver disposição diversa, a presença de pelo menos $3 / 4$ (três quartos) dos associados e o voto favorável da maioria dos presentes. Para deliberar a dissolução da associação e a devolução do patrimônio também é necessário o voto favorável de pelo menos $3 / 4$ (três quartos) dos membros ${ }^{526}$. Como mencionamos, no Brasil não há previsão legal de quorum para as deliberações acerca destas matérias. Entendemos que, em razão de sua relevância, o estatuto das entidades deveria prever quoruns qualificados nessas hipóteses.

A deliberação é a vontade da assembleia, pois o seu modo de formação, conhecido como método colegiado, transforma uma pluralidade de declarações individuais em uma nova vontade unitária e coletiva, formada no conclave. É, portanto, a vontade de um número de membros inferior à totalidade, em razão do princípio da maioria, à qual é atribuída eficácia vinculante para a totalidade dos associados. Nas associações, a

\footnotetext{
${ }^{523}$ Les Sociétés cit. (nota 126 supra), pp. 162-163.

${ }^{524}$ Cf. F. Galgano, Persone giuridiche cit. (nota 57 supra), pp. 326-327.

${ }^{525}$ F. Galgano, Persone giuridiche cit. (nota 57 supra), pp. 326-327.

${ }^{526}$ F. GALGANO, Persone giuridiche cit. (nota 57 supra), pp. 315-317.
} 
operatividade do princípio da maioria é subordinada à adoção, por parte do grupo, do método colegial $^{527}$.

A convocação da assembleia deverá ser feita na forma estabelecida pelo estatuto e, se este for omisso, mediante aviso pessoal que contenha a ordem do dia. A convocação irregular torna inválidas as deliberações tomadas, e não poderá ser sanada, mesmo se for provado que o aviso foi levado a conhecimento de todos os associados, salvo em caso de violação de disposições relativas à publicidade ou à notificação do aviso de convocação ${ }^{528}$.

As deliberações serão válidas somente se resultarem da reunião dos associados em assembleia, pois elas devem se originar de uma série de discussões e de um contraditório útil à informação recíproca e esclarecimentos entre eles. O estatuto não pode substituir o método colegiado pelo referendum e não é admitido o voto por correspondência. É permitida, porém, a representação dos associados em assembleia, salvo se houver proibição estatutária, desde que seja feita por outros membros, mas não por terceiros ou pelos administradores da entidade, mediante procuração escrita com referência ao aviso de convocação ${ }^{529}$.

A assembleia é presidida pela pessoa indicada pelo estatuto e, na sua ausência, por aquela escolhida pelos presentes. O presidente tem como função verificar a sua constituição regular e resolver os conflitos ocorrentes, devendo controlar a discussão, o êxito da votação e proclamar o resultado. Os associados dispõem, cada um, de um só voto. Eventuais disposições contrárias ao estatuto serão nulas. As deliberações devem constar em ata ${ }^{530}$.

A atividade da assembleia se articula em deliberações, sendo cada uma delas formada pelo conjunto de votos que convirjam sobre determinado conteúdo. Pode ser uma maioria relativa, calculada em relação aos participantes da assembleia; absoluta, calculada em relação aos membros da assembleia; simples, correspondente a metade dos votos dos associados mais um, ou qualificada, consistente em quotas superiores de

\footnotetext{
${ }^{527}$ F. GAlgano, Persone giuridiche cit. (nota 57 supra), pp. 322-324. A deliberação se forma mediante um procedimento que passa, necessariamente, por diversas fases: a convocação do grupo, a reunião dos membros em assembleia, a discussão e, finalmente, a votação.

${ }^{528}$ F. Galgano, Persone giuridiche cit. (nota 57 supra), p. 327.

${ }^{529}$ F. Galgano, Persone giuridiche cit. (nota 57 supra), pp. 328-330. Os associados representados são computados para efeito da obtenção da maioria e do quorum de presença.

${ }^{530}$ F. GALGANO, Persone giuridiche cit. (nota 57 supra), pp. 328- 330.
} 
votação, como $2 / 3$ (dois terços), 3/4 (três quartos) e outros. A unanimidade é necessária apenas em alguns casos ${ }^{531}$.

A eventual inércia continuada da assembleia comporta a dissolução da associação. As normas sobre a participação nos conclaves e sobre os procedimentos de votação possuem a função de garantir que as deliberações não se desviem dos interesses do qual o grupo é portador ${ }^{532}$.

Nesse sentido, regula-se a convocação da assembleia e se fixa a quantidade de membros e de votos necessários para decidir sobre determinada matéria de forma válida. Tais pontos são pré-estabelecidos, diferenciando o quorum necessário de acordo com as matérias postas em votação pela ordem do dia. O legislador busca garantir que, pelo menos em relação aos assuntos essenciais para o ente, sejam chamados a deliberar todos os membros ${ }^{533}$.

A disciplina sobre o procedimento de tomada de deliberações em assembleia pode ser derrogada pelo ato constitutivo e pelo estatuto da entidade, que podem estabelecer maiorias diferentes das previstas no Código Civil italiano. Não podem, contudo, ser inseridas nos estatutos cláusulas contrárias a princípios constitucionais, como proibir a participação a determinados associados na assembleia sem justa causa ${ }^{534}$.

Y. GUYON ressalta que os estatutos devem respeitar os direitos fundamentais e individuais dos associados, que muitas vezes são genéricos e imprecisos. A liberdade do estatuto no tocante à proteção dos membros parece ser grande, a princípio, pois a organização e o funcionamento da coletividade dos associados raramente interessam aos terceiros $^{535}$.

Por essa razão, questiona-se a possibilidade dos estatutos modificarem as regras que regem o acesso às assembleias bem como os seus poderes e seu funcionamento. As sociedades anônimas simplificadas francesas podem fazê-lo, pois possuem liberdade estatutária absoluta, desde que respeitem os princípios gerais de direito das sociedades e a competência reservada à coletividade dos sócios para a tomada de decisões ${ }^{536}$.

\footnotetext{
${ }^{531}$ Cf. M. BASILE, Le Persone giuridiche cit. (nota 54 supra), pp. 223-224.

${ }^{532}$ Cf. M. BASILE, Le Persone giuridiche cit. (nota 54 supra), pp. 224-225.

${ }^{533}$ Cf. M. BASILE, Le Persone giuridiche cit. (nota 54 supra), pp. 224-225.

${ }^{534}$ Cf. M. BASILE, Le Persone giuridiche cit. (nota 54 supra), p. 225.

${ }^{535}$ Les Sociétés cit. (nota 126 supra), p. 217.

${ }^{536}$ Ver Y. GuYON, Les Sociétés cit. (nota 126 supra), p. 217. O autor adverte que a situação é mais complexa nas sociedades anônimas e limitadas.
} 
No direito francês, todos os associados possuem o direito de participar das decisões coletivas, não podendo os estatutos prever obstáculos a esta prerrogativa fundamental. A chamada 'cláusula de estágio', que subordina o exercício do direito de voto a uma antiguidade mais ou menos longa na sociedade ou na associação, deve, para o autor acima citado, ser reputada como não escrita ${ }^{537}$.

O mesmo vale para as cláusulas de sustentabilidade, que coloquem algum óbice, mesmo que temporário, a uma modificação, do objeto ou da forma de sociedade ou associação, pois os estatutos não podem suprimir uma das atribuições da coletividade dos associados, sem a transferir a outro órgão social ${ }^{538}$.

A ordem pública está muito presente no que se refere ao funcionamento da coletividade dos associados, sendo eventuais alterações raramente válidas, o que nos faz refletir acerca da possibilidade de redução do quorum para a tomada de determinadas deliberações. Esta diminuição não pode ser determinada no estatuto, pois a assembleia não seria suficientemente representativa, mas, se ainda assim o fizer, as cláusulas serão consideradas como não escritas, e a deliberação tomada com base nelas, nula ${ }^{539}$.

Por outro lado, devemos analisar a possibilidade dos estatutos requererem, para a validade das deliberações da assembleia geral, um quorum mais elevado que aquele previsto pela lei, ressaltando desde já que a questão é controvertida. Numa primeira análise, parece que essas cláusulas só trazem vantagens, conferindo à sociedade ou associação um caráter mais democrático, tendo a jurisprudência francesa admitido a validade de um reforço estatutário do quorum. Contudo, alguns doutrinadores franceses ainda são contrários a esta posição, entendendo que tais cláusulas poderiam trazer a risco de acarretar a paralisia da sociedade, nas assembleias ordinárias, uma vez que a não aprovação das contas ou a ausência de nomeação dos administradores colocaria a sociedade ou associação em uma situação irregular ${ }^{540}$.

Esses argumentos levaram a não se admitir a validade das cláusulas que aumentam o quorum na primeira convocação, e na segunda convocação devem ser reputadas como não escritas. Y. GUYON entende, contudo, que se o quorum é uma regra de proteção aos acionistas minoritários ou ausentes, os estatutos devem poder aumentar tal

\footnotetext{
${ }^{537}$ Ver Y. GUYON, Les Sociétés cit. (nota 126 supra), pp. 217-218.

${ }^{538}$ Ver Y. GUYON, Les Sociétés cit. (nota 126 supra), p. 217.

${ }^{539}$ Ver Y. GuYON, Les Sociétés cit. (nota 126 supra), pp. 219-221. O quorum é a fração do capital social que deve estar presente ou representada para que uma assembleia possa deliberar validamente.

${ }^{540}$ Ver Y. GUYON, Les Sociétés cit. (nota 126 supra), pp. 221-222.
} 
proteção. Por outro lado, um quorum estatutário mais elevado poderia colocar obstáculos à destituição "ad nutum" dos administradores ou dos membros do conselho de supervisão, o que é de ordem pública. Conclui-se que deve ser reputada como não escrita a cláusula que preveja um quorum mais elevado somente para as resoluções que envolvam a destituição dos dirigentes. Assim, é preferível que as cláusulas de reforço do quorum não se apliquem para as resoluções acerca da nomeação ou revogação dos gestores, o que podemos aplicar às associações ${ }^{541}$.

A validade das cláusulas estatutárias que reforçam a maioria, é igualmente discutida. Sustenta-se que as condições de maioria são imperativas, pois são sancionadas por uma nulidade. A jurisprudência francesa não tem uma orientação dominante, mas parece favorável às cláusulas que reforçam a maioria, com as mesmas hesitações que para as cláusulas de quorum. Devem ser consideradas válidas, para o autor, pois não colocam obstáculos à destituição "ad nutum" dos administradores ou membros do conselho de administração ${ }^{542}$.

Já em relação ao direito de voto, as amenizações à regulamentação legal são, a princípio, suspeitas nas sociedades, porque o minoritário, uma vez privado do seu direito de participar das decisões coletivas, pode se sentir despido de suas prerrogativas pecuniárias. O direito de voto constitui um atributo essencial do acionista e uma garantia inseparável dos seus direitos pecuniários. O mesmo vale para as associações, a não ser que haja justa causa, como a falta de pagamento das contribuições ${ }^{543}$.

Por fim, os estatutos não podem transferir ao conselho de administração as atribuições que a lei confere à assembleia, reputando-se tais cláusulas como não escritas ${ }^{544}$.

Também no direito alemão, de acordo com F. KÜBLER, a assembleia dos associados é o órgão a quem compete a formação da vontade da associação, tendo um caráter preeminente frente à diretoria. Todas as decisões que afetam a entidade devem ser tomadas, em princípio, na assembleia, a não ser que os estatutos prevejam outras competências $^{545}$.

\footnotetext{
${ }^{541}$ Les Sociétés cit. (nota 126 supra), pp. 221-222.

${ }^{542}$ Les Sociétés cit. (nota 126 supra), pp. 223-224.

${ }^{543}$ Cf. Y. GuYON, Les Sociétés cit. (nota 126 supra), p. 225.

${ }^{544}$ Cf. Y. GuYON, Les Sociétés cit. (nota 126 supra), pp. 228-229.

545 Derecho de Sociedades cit. (nota 61 supra), pp. 210-211. O BGB menciona expressamente algumas competências privativas da assembleia: eleição da diretoria, e sua destituição a qualquer momento, salvo pacto em contrário; modificação dos estatutos, com maioria de 3/4 (três quartos) dos associados presentes; modificação da finalidade da associação, por unanimidade, sendo necessário inclusive o consentimento dos
} 
No estatuto deve estar previsto que a assembleia se reunirá pelo menos uma vez por ano, sendo a convocação normalmente feita pela diretoria, devendo haver outras sempre que o interesse da associação o exigir. Poderá ser feita por um décimo dos membros (ou o quanto determinar o estatuto), por escrito, mencionando a finalidade e os motivos. Todos os associados devem ser convocados, mencionando-se a ordem do dia, sob pena de nulidade ${ }^{546}$.

A assembleia dos associados toma as suas decisões através de deliberações. Salvo previsão contrária do estatuto, cada um possui o direito de emitir um voto, sendo suficiente a maioria simples, a não ser em caso de modificação estatutária e das finalidades da entidade. As maiorias se computam sobre os associados presentes, não devendo o voto nulo ser incluído no cômputo. Da mesma forma que em outras entidades privadas são permitidos os acordos sobre os votos, tanto entre associados quanto entre terceiros, mas a sua validade é limitada por disposições legais, pelo estatuto e pelos bons costumes, assim como pelo dever de lealdade que o membro deve observar em relação ao ente ${ }^{547}$.

Mencionamos, em seguida, alguns entendimentos jurisprudenciais no Brasil, acerca das deliberações da assembleia dos associados.

$\mathrm{Na}$ assembleia podem participar apenas os associados adimplentes, sendo que suas deliberações regularmente tomadas vinculam a todos, inclusive os ausentes e dissidentes $^{548}$. A assembleia realizada para eleição da mesa administrativa, que admitiu a inscrição e participação no pleito eleitoral de membro não sócio, contrariando o estatuto, é nula. A admissão de sócio deve ocorrer consoante a observação das prescrições estatutárias e legais ${ }^{549}$.

A convocação das assembleias e a tomada de deliberações devem seguir determinadas formalidades ${ }^{550}$. Pode haver, inclusive, previsão estatutária de quorum qualificado para a deliberação acerca de determinadas matérias ${ }^{551}$.

ausentes, que pode ser dado tacitamente, podendo os estatutos prever a modificação com aprovação da maioria. Notamos que também o legislador alemão fixou um quorum qualificado para determinadas matérias. ${ }_{546}$ Cf. F. KÜBLER, Derecho de Sociedades cit. (nota 61 supra), pp. 211-212.

${ }^{547}$ Cf. F. KÜBLER, Derecho de Sociedades cit. (nota 61 supra), pp. 212- 213.

${ }^{548}$ Ver o seguinte julgado: “Assembleia geral extraordinária de associação para alteração de estatuto. As deliberações tomadas em AGE, realizada dentro dos limites legais e estatutários, obrigam a todos os associados, ainda que ausentes ou discordantes". TJMG, 9a Câm. Cível, Apel. Cível n. 1070206297516-5001, rel. Osmando Almeida, j. 4-3-2008.

${ }^{549}$ TACMG, $7^{\text {a }}$ Câm. Cível, Apel. Cível n. 2.0000.00.414867-2/000(1), rel. Guilherme Luciano Baeta Nunes, j. 24-3-2004.

${ }^{550}$ Em relação à convocação ver o seguinte julgado: “Anulação de assembleia convocada para destituição de diretoria em razão das deliberações não corresponderem aos temas constantes do edital e de inexistir prova de 
É competência privativa da assembleia geral a alteração do estatuto social. Ela pode, inclusive, aprovar a modificação de associação para sociedade anônima, por deliberação regularmente tomada pelos sócios aptos a emitir a sua opinião, sem computar aqueles que por desídia ou desinteresse foram excluídos da associação ${ }^{552}$.

IV.3. Deliberações nulas e anuláveis. Legitimidade para a sua impugnação. Aplicação da disciplina dos contratos

Após tratar da competência, convocação, instalação e da forma de tomada de deliberações pela assembleia dos associados, passaremos a analisar a sua validade.

As deliberações assembleares contrárias à lei ou aos estatutos são anuláveis, podendo a sua anulação ser pleiteada por todos os associados que discordarem delas, bem como pelo terceiro prejudicado. A ação deve ser proposta contra a associação ${ }^{553}$.

A deliberação assemblear pode também ser nula, em outros casos diversos dos enunciados acima, como quando for tomada por maioria, quando a lei exigia unanimidade, podendo a ação ser proposta por qualquer membro ou interessado, sempre em face da entidade ${ }^{554}$.

No mesmo sentido, F. GALGANo sustenta que na Itália as deliberações da assembleia contrárias à lei, ao ato constitutivo ou ao estatuto podem ser anuladas pelos órgãos da associação, por provocação de qualquer associado e pelo Ministério Público. A

que a convocação fora promovida por $10 \%$ dos associados, de acordo com o estatuto. Validade das assembleias subsequentes, regularmente convocadas e independentes". TJSP, $3^{\mathrm{a}}$ Câm. de Dir.Priv. de Férias“Jan/2003”, Apel. Cível n. 134744-4/2-00, rel. Carlos Roberto Gonçalves, j. 28-1-2003.

${ }^{551}$ Ver o seguinte julgado: "Associação sem fins lucrativos com apenas 3 associados e diretores. Falecimento do diretor presidente. Exigência dos estatutos de maioria absoluta para admitir sócio substituído e para eleger sócio para a diretoria. Quorum inexistente sem a participação dos 2 remanescentes. A filha do Diretor falecido não pode votar na assembleia pela sua própria admissão e nomeação, por se tratar de direito não patrimonial intransmissível por herança. A associação está impedida e não pode ter fins lucrativos, seus sócios entram com o trabalho e não existem lucros, rendimentos, ou quotas sociais a repartir e transmitir". TJSP, $8^{\text {a }}$ Câm. de Dir.Priv., Apel. Cível n. 107221.4/3-00, rel. Silvio Marques Neto, j. 27-11-2000.

${ }^{552}$ TJRJ, $1^{a}$ Câm. Cível, Apel. Cível n. 0132354-69.2009.8.19.0001, rel. Maria Augusta Vaz Monteiro de Figueiredo, j. 2011.

${ }^{553}$ Ver F. C. PONTES DE MIRANDA, Tratado de Direito Privado cit. (nota 4 supra), p. 382. Nesses casos, a sentença que anular a deliberação assemblear será constitutiva negativa, com eficácia erga omnes. Aí se enquadram as hipóteses de ações propostas em razão da irregularidade da convocação da assembleia ou do defeito no cômputo dos votos.

${ }^{554}$ Ver F. C. PONTES DE MIRANDA, Tratado de Direito Privado cit. (nota 4 supra), p. 386: "Deliberações nulas há, porém não são aquelas cuja invalidade resulta de nulidades ou anulações de votos: a) se a unanimidade era de exigir-se; b) se a lei mesma a disse nula (art. 145, V, e.g., art. 1372)". 
autoridade judiciária, ouvidos os administradores da entidade, pode suspender a execução da deliberação impugnada, quando houver graves motivos. A suspensão deve ser motivada, notificando-se aos gestores. A execução de deliberações contrárias à ordem pública e aos bons costumes pode ser suspensa pela autoridade administrativa ${ }^{555}$.

A impugnação é admitida para motivos de legitimidade e não por motivos de mérito, não podendo o impugnante requerer a revisão judicial da oportunidade ou conveniência da deliberação. $\mathrm{O}$ exame do mérito só é admitido quando for necessário para apreciar a existência de um vício de legitimidade, sobretudo em casos de excesso ou abuso de poder da maioria. Isso ocorre quando a maioria agir não para realizar o interesse da associação, e sim de algum estranho a ela ${ }^{556}$.

Para apreciar o abuso, o juiz deve analisar o mérito da deliberação. Não deve decidir se ela foi tomada no interesse da associação, e sim verificar se os seus objetivos se enquadram na esfera de interesses delimitada no estatuto da entidade ou pareçam extraassociativos aos componentes da maioria assemblear, como interesses pessoais ou de outra comunidade ${ }^{557}$.

As deliberações tomadas em violação à lei, ao ato constitutivo ou estatuto são anuláveis, mas tal anulação não prejudica os direitos adquiridos pelos terceiros de boafé com fundamento nos atos praticados em execução da própria deliberação. A disciplina aplicável, para o autor acima citado, é a de anulação do contrato, pois as deliberações assembleares seriam a soma de uma pluralidade de negócios unilaterais. A anulação da deliberação que viola normas legais contrasta com a nulidade do negócio jurídico contrário a normas imperativas. Aquelas tomadas com objeto ilícito nas associações, diferentemente do que ocorre nas sociedades, são anuláveis, o mesmo valendo para as contrárias à ordem pública e aos bons costumes ${ }^{558}$.

A legitimação para propositura da ação de anulação é atribuída, inicialmente, aos órgãos do ente: administradores e outros, como comitê de fiscalização ou outros órgãos de vigilância, semelhantes ao conselho fiscal das sociedades, previstos no estatuto das associações. É atribuída também aos membros, de qualquer categoria, a não ser que tenham votado pela aprovação da deliberação impugnada. Já o Ministério Público atua tutelando o interesse público, prejudicado pela deliberação tomada, e não o interesse

\footnotetext{
${ }^{555}$ Persone giuridiche cit. (nota 57 supra), pp. 333-339.

${ }^{556}$ Cf. F. Galgano, Persone giuridiche cit. (nota 57 supra), pp. 331-332.

${ }^{557}$ Cf. F. Galgano, Persone giuridiche cit. (nota 57 supra), pp. 331-332.

${ }^{558}$ Cf. F. GAlgano, Persone giuridiche cit. (nota 57 supra), pp. 333-334.
} 
da entidade. A sua ação se justifica porque as associações, pela própria natureza dos objetivos que buscam, podem tomar deliberações contrárias ao interesse público ${ }^{559}$.

A impugnação judicial não suspende, de regra, a execução da deliberação, salvo quando houver graves motivos. Essa disposição não se aplica no caso de contestação feita por administradores, que não podem ser obrigados a executar uma deliberação que estão questionando. A deliberação não será anulada se for substituída por outra, tomada conforme a lei ou o ato constitutivo ${ }^{560}$.

Existem alguns limites para a aplicação da disciplina da anulação da deliberação. Ela não se aplica à hipótese de invalidade do único voto. Os votos podem ser anuláveis por incapacidade, erro, dolo e coação. Deverá ser requerida, nesses casos, somente por aquele que o preferiu, e não pelos associados ou por outros órgãos da associação. Se o voto for decisivo para o alcance da maioria, a deliberação poderá ser $\operatorname{anulada}^{561}$.

A deliberação pode ser nula, sendo a ação, neste caso, imprescritível, cabendo a qualquer interessado e alcançando também os direitos do terceiro de boa-fé. Para o autor acima citado, quando se fala de nulidade das deliberações, devemos pensar nas hipóteses de inexistência e ineficácia. As hipóteses de inexistência da deliberação foram identificadas, nas sociedades, nos casos em que não se podiam considerar simplesmente anuláveis. Podem ser tidas como inexistentes, tanto nas sociedades como nas associações, as hipóteses de deliberações tomadas por um órgão colegiado que não se identifique como assembleia ${ }^{562}$. O princípio violado é o da maioria de dispor da $\operatorname{associação~}^{563}$.

\footnotetext{
${ }^{559}$ Cf. F. Galgano, Persone giuridiche cit. (nota 57 supra), p. 335.

${ }_{560}$ Cf. F. Galgano, Persone giuridiche cit. (nota 57 supra), p. 339.

${ }^{561}$ Cf. F. Galgano, Persone giuridiche cit. (nota 57 supra), pp. 339-340.

${ }^{562}$ Cf. F. Galgano, Persone giuridiche cit. (nota 57 supra), pp. 340-341. O autor cita como exemplos de deliberações nulas: quando um grupo de associados se reúne sem convocação de todos, tomando uma deliberação; quando há convocação, mas apenas de uma minoria; deliberações tomadas por uma maioria aparente, quando pessoas estranhas foram computadas para alcance da maioria.

${ }^{563}$ Cf. F. Galgano, Persone giuridiche cit. (nota 57 supra), p. 342. Para o autor, também se classificam como ineficazes: as deliberações que excedam a competência da assembleia, invadindo a esfera de competência do órgão administrativo; as deliberações que violarem os direitos especiais ou privilegiados ou adquiridos pelos associados, também nesse caso por defeito de legitimação da maioria de dispor de direitos do associado. O mesmo vale para deliberações lesivas aos direitos individuais, reconhecidos a todos os associados. As deliberações assembleares que excluíssem o direito de voto de determinadas categorias de associados, que vetasse a possibilidade de fazer impugnações judiciais ou excluísse o direito de recesso dos associados não seria anulável por ser contrária à lei, e sim ineficaz, por defeito de legitimação da associação de dispor dos direitos de outros.
} 
Mas o autor prefere, em vez de se falar em inexistência, adotar o termo ineficácia.

No mesmo sentido M. BASILE explica que o Código italiano conferiu legitimidade ao Ministério Público e à autoridade do governo, respectivamente, para impugnar e suspender as deliberações assembleares ilegítimas ${ }^{564}$.

As deliberações contrárias à lei, ao ato constitutivo e ao estatuto são anuláveis, por isso garante-se que a assembleia exerça as suas competências com a finalidade de perseguir os escopos coletivos. $\mathrm{O}$ associado possui a liberdade de participar ou não do conclave e de exprimir o seu voto. Contudo, controla-se a forma como ele vota, não podendo se posicionar a favor de uma iniciativa contrária à lei, ao ato constitutivo e ao estatuto $^{565}$.

O controle da deliberação, no sentido de visar o interesse da associação, é reforçado por alguns deveres, como o de diligência e de lealdade, e por princípios gerais. $\mathrm{O}$ dever de lealdade está ligado ao princípio da boa-fé na execução dos contratos, enquanto que o de diligência no cumprimento das obrigações é um meio de se avaliar o cumprimento do dever, podendo a negligência acarretar responsabilidades ${ }^{566}$.

M. BASILE entende, diferentemente de F. GALGANO, que as deliberações assembleares seguem as regras e os princípios colocados acima, restando pouco espaço para outras disciplinas, como os princípios gerais dos contratos. A maior parte dos princípios contratuais não parece para ele aplicável à estrutura e funções das deliberações assembleares. A autonomia, por exemplo, não se aplica às deliberações, que devem ser tomadas de acordo com os limites do ato constitutivo. Os princípios sobre os requisitos dos contratos também não se aplicam, porque neles incidem as normas procedimentais e substanciais previstas no ato e estatuto. Contudo, parece parcialmente compatível com as deliberações a disciplina de condições e interpretação desses instrumentos ${ }^{567}$.

As deliberações assembleares têm eficácia - subordinada à validade destas sobretudo, no interior do ente, vinculando os órgãos executivos e todos os associados ${ }^{568}$.

\footnotetext{
${ }^{564}$ Le persone giuridiche cit. (nota 54 supra), p. 234.

565 Ver M. BASILE, Le persone giuridiche cit. (nota 54 supra), pp. 225-226.

${ }^{566}$ Ver M. BASILE, Le persone giuridiche cit. (nota 54 supra), pp. 226-228.

${ }^{567}$ Ver M. BASILE, Le persone giuridiche cit. (nota 54 supra), p. 229.

${ }^{568}$ Ver M. BASILE, Le persone giuridiche cit. (nota 54 supra), pp. 229-230.
} 
Para as associações italianas reconhecidas, o código prevê que se uma deliberação for contrária à lei, ao ato constitutivo ou ao estatuto, poderá ser anulada, excluindo a nulidade, o que se aplica às associações não reconhecidas se presentes os requisitos para a analogia. Trata-se de um mecanismo de salvaguarda da vontade da maioria assemblear. A anulabilidade é a solução para qualquer defeito deliberativo, diversamente do quanto é estabelecido nos regimes de remédios das patologias negociais. Contudo, para o autor acima citado, os possíveis vícios das deliberações são mais amplos que as hipóteses acima tratadas, e existem alternativas além da anulação ${ }^{569}$.

As deliberações assembleares são atos de atuação do escopo associativo e colegiais que concluem um procedimento. Isso se reflete na disciplina de seus possíveis defeitos, acarretando a anulação das deliberações tomadas para realizar interesses estranhos aos fins do ente ou contrários ao conteúdo dos atos que definem os seus interesses - as deliberações contrárias à lei, ao ato constitutivo e ao estatuto da entidade. Contudo, parece configurar outra hipótese no caso das invalidades de deliberações que se extraiam da combinação da disciplina especial posta para o ente com os diversos princípios do sistema ${ }^{570}$.

A natureza colegial da deliberação impede que ela seja válida se não houver a convergência da pluralidade de votos necessária prevista pela lei ou pela autonomia coletiva. $\mathrm{O}$ vício de apenas um voto não assume relevo se o número de sufrágios válidos bastarem para atingir o quorum necessário para a formação da deliberação. A falta da pluralidade não parece ser uma contrariedade à lei, ao ato constitutivo ou ao estatuto, e sim é semelhante à falta de um elemento essencial do contrato, sancionada com a nulidade. Usando a terminologia aplicável às sociedades, M. BASILE fala em inexistência da deliberação, ressaltando que a nulidade pode, contudo, ser prevista pelo ato constitutivo ${ }^{571}$.

Também não se enquadram nos casos de anulação citados as hipóteses de ilicitude das deliberações, ou seja, quando esta violar ou contornar normas inderrogáveis que limitem os interesses perseguíveis ou as atividades através das quais tais interesses possam ser alcançados. Existe uma tendência do sistema a incluí-las nas causas de nulidade, e não de anulação ${ }^{572}$.

\footnotetext{
${ }^{569}$ Ver M. BASILE, Le persone giuridiche cit. (nota 54 supra), p. 230.

${ }^{570}$ Ver M. BASILE, Le persone giuridiche cit. (nota 54 supra), p. 231.

${ }^{571}$ Le persone giuridiche cit. (nota 54 supra), p. 229.

${ }^{572}$ Ver M. BASILE, Le persone giuridiche cit. (nota 54 supra), pp. 230-234.
} 
Acerca da possibilidade de intervenção judicial no conteúdo das deliberações, a jurisprudência italiana tem entendido que pode ser admitida a verificação da conformidade da decisão com a lei, o ato constitutivo e o estatuto, o que implicaria, necessariamente, no exame do conteúdo da deliberação. Não poderá haver, porém, um juízo sobre a oportunidade da mesma. Para examinar se o dever de diligência foi respeitado, não há necessariamente uma ligação com a concreta realização do interesse do grupo $^{573}$.

Os Tribunais brasileiros seguem a mesma orientação em relação à possibilidade do Judiciário intervir nas deliberações tomadas pela assembleia dos associados. Decidiram que as decisões tomadas podem ser julgadas pelo referido poder somente do ponto de vista formal e ou legal, e, cumprido o estatuto, deve ser mantido o que foi decidido ${ }^{574}$.

Portanto, a doutrina italiana parece concluir que as deliberações assembleares podem ser anuláveis e também nulas.

O ato pode ser impugnado somente pelo sujeito em cujo interesse a ação é prevista. Os órgãos associativos podem agir apenas para denunciar a contrariedade da deliberação com as normas postas para tutelar o interesse da coletividade dos membros. No interior do ente, a decisão de agir judicialmente cabe à própria assembleia, mas na prática isso raramente é feito, acabando por se substituir a deliberação viciada. Uma decisão desse tipo se enquadra nos poderes dos administradores, mas o estatuto pode prever que seja reservado a determinado órgão ${ }^{575}$.

Os associados possuem legitimidade para fazer valer a inobservância, por parte da assembleia, das normas postas a tutelar seus interesses individuais ou como membros. Existe uma tendência a excluir dos sujeitos aptos a impugnar a deliberação os associados que a aprovaram, com o que discorda M. BASILE. Em relação ao Ministério Público, a sua legitimidade para impugnar as deliberações foi consequência de um dado histórico de controle das associações reconhecidas pelo Estado. Hoje se colocam limites para isso, parecendo ser admissível a intervenção somente em casos de contrariedade da deliberação assemblear a uma norma jurídica de ordem pública ${ }^{576}$.

\footnotetext{
${ }^{573}$ Ver M. BASILE, Le persone giuridiche cit. (nota 54 supra), pp. 231-232.

${ }^{574}$ TJMG, $3^{\text {a }}$ Câm. Cível, Apel. Cível n. 2000000432606-7/000(1), rel. Maurício Barros, j. 25-8-2004.

${ }^{575}$ Ver M. BASILE, Le persone giuridiche cit. (nota 54 supra), pp. 234-235.

${ }^{576}$ Le persone giuridiche cit. (nota 54 supra), pp. 235-238.
} 
M. SANTORINI explica que não há normas reguladoras para a validade das deliberações assembleares de associações não reconhecidas italianas, mas a doutrina e a jurisprudência fornecem um critério unívoco: tais deliberações são anuláveis e nunca nulas. Por analogia com as associações reconhecidas, aplica-se o artigo 23 do Código Civil italiano $^{577}$. Contudo, questiona se existe uma semelhança tal entre os dois tipos de entidades que possa justificar a aplicação da disciplina das primeiras por analogia às segundas, e procura analisar se o referido artigo é de fato aplicável, bem como se em matéria de associações existe ou não a distinção entre nulidade e anulação ${ }^{578}$.

Existem poucas normas sobre as associações que não demandaram a obtenção da personalidade jurídica ou não a obtiveram, e uma delas prescreve que os acordos dos associados devem reger o ordenamento interno e a administração dessas entidades. O legislador deixou para a autonomia privada a função de formular as regras sobre o ordenamento interno e sobre a administração desses entes. Já para as associações reconhecidas, quando se visa obter do Estado um reconhecimento, que é expressão de uma esfera mais ampla de capacidade jurídica, o legislador fixou o conteúdo do ato constitutivo. No seu ordenamento interno, é especificada a presença de uma pluralidade de órgãos que dividem as funções das entidades e se controlam reciprocamente. Como há poucas normas para as associações não reconhecidas, surgiu a ideia de aplicação por analogia das normas das reconhecidas ${ }^{579}$.

O autor não concorda com a aplicação da analogia para os órgãos das associações, em especial em relação às deliberações assembleares. Para saber se o referido artigo 23 é aplicável, por analogia, às entidades não reconhecidas, o ato constitutivo da

577 “Art. 23 Annullamento e sospensione delle deliberazioni Le deliberazioni dell'assemblea contrarie alla legge, all'atto costitutivo o allo statuto possono essere annullate su istanza degli organi dell'ente, di qualunque associato o del pubblico ministero.

L'annullamento della deliberazione non pregiudica i diritti acquistati dai terzi di buona fede in base ad atti compiuti in esecuzione della deliberazione medesima $(1445,2377)$.

Il Presidente del tribunale o il giudice istruttore, sentiti gli amministratori dell'associazione, può sospendere, su istanza di colui che l'ha proposto l'impugnazione, l'esecuzione della deliberazione impugnata, quando sussistono gravi motivi. Il decreto di sospensione deve essere motivato ed è notificato agli amministratori (att. 10).

L'esecuzione delle deliberazioni contrarie all'ordine pubblico o al buon costume può essere sospesa anche dall'autorità governativa (att. 9)."

${ }^{578}$ Invalidità delle delibere di associazioni, Padova, Cedam, 1992, pp.2-4. Ressalta-se que para alguns as deliberações são atos negociais e podem ser nulas, se contrárias a normas imperativas, a ordem pública e aos bons costumes.

${ }^{579}$ M. SANTORINI, Invalidità delle delibere cit. (nota 578 supra), pp. 6-7. As normas das associações não reconhecidas se limitam a disciplinar a tutela dos credores e a representação em juízo. Apesar do acima descrito, alguns aplicam a elas a normativa que regula o ordenamento interno e a administração das associações reconhecidas, com o que o autor é contrário, por não parecer estar de acordo com o sistema adotado pelo Código Civil. 
associação deve prever um órgão assemblear em contraposição a um órgão de administração. Deve ocorrer também um pressuposto negativo: ao se valer da autonomia contratual os membros não devem ter feito referimento a formas de tutela, em especial a remédios negociais de direito comum ${ }^{580}$.

Contudo, mesmo se a associação não reconhecida possuir uma assembleia, com uma hipotética deliberação, contrária à lei, ao ato constitutivo ou ao estatuto, não se pode dizer com certeza que se aplica o artigo 23 do Código italiano. Considerando que os associados podem livremente estipular as suas regras e não o fizeram, deve-se aplicar o artigo $1.374^{581}$ do mesmo Código. Ocorre que tal dispositivo que trata da integração do contrato aplica a analogia, que pressupõe a lacuna da lei. Outra fonte de integração admitida legalmente é a equidade. Assim, em matéria contratual existem princípios de direito comum que regulam as hipóteses disciplinadas no quadro de anulação do referido artigo $23^{582}$.

Dessa forma, aplicando-se a equidade e o direito comum, atingimos os mesmos resultados do recurso analógico citado. A analogia pressupõe a incidência de todas as regras, mas para o autor não caberia, porém, legitimidade ao Ministério Publico para pleitear a anulação das deliberações da associação não reconhecida e não seria possível a sua suspensão pela autoridade governativa ${ }^{583}$.

Tratamos das hipóteses em que no ordenamento interno do ente não reconhecido não haja uma subdivisão entre órgãos deliberativos e executivos. Havendo tal previsão, o remédio previsto para a tutela dos associados deveria ser buscado, da mesma forma, nos princípios contratuais de direito comum, ou ainda nas cláusulas de uso e de equidade $^{584}$.

A jurisprudência e doutrina têm entendido que as normas do referido artigo 23, em caso de omissão, devem ser aplicadas para as deliberações das associações não reconhecidas por analogia, mencionando alguns a interpretação extensiva. Contudo,

\footnotetext{
${ }^{580}$ M. SANTORINI, Invalidità delle delibere cit. (nota 578 supra), p. 10.

581 “Art. 1.374 Integrazione del contratto

Il contratto obbliga le parti non solo a quanto e nel medesimo espresso, ma anche a tutte le conseguenze che ne derivano secondo la legge, $\mathrm{o}$, in mancanza, secondo gli usi e l'equità."

${ }^{582}$ M. SANTORINI, Invalidità delle delibere cit. (nota 578 supra), pp. 11-12.

${ }^{583}$ M. SANTORINI, Invalidità delle delibere cit. (nota 578 supra), pp. 12-13.

${ }^{584}$ M. SANTORINI, Invalidità delle delibere cit. (nota 578 supra), pp.13-14. Sendo assim, se concluirmos para as associações reconhecidas que as deliberações das assembleias podem ser anuladas e também nulas, a mesma conclusão, mesmo por aplicação do direito comum, deve ser sustentada para associações não reconhecidas.
} 
ocorrendo a analogia, as deliberações dos entes não reconhecidos nunca seriam nulas, mas sempre anuláveis, pois a redução de todas as anomalias ao remédio da anulação é aplicável para as associações reconhecidas ${ }^{585}$.

As deliberações das assembleias das associações são derrogatórias da regra geral ditada para os contratos ${ }^{586}$, extensível a todos os atos privados. Considera anuláveis também aquelas contrárias à ordem pública e aos bons costumes, bem como todas as outras hipóteses de deliberações nulas, ao contrário do que é previsto para algumas sociedades. A disciplina societária menciona a hipótese de nulidade no artigo $2.379^{587}$ do Código italiano, enquanto o artigo 23 a exclui para as associações ${ }^{588}$.

Durante a preparação do Código Civil italiano a distinção entre nulidade e anulação não era muito clara e presente aos legisladores, em especial para tratar da possibilidade de se sanar ou não o vício. Perduravam dúvidas, mas algumas hipóteses certamente não se encaixavam em casos de anulação. A opinião da doutrina que enquadra quase tudo como anulação parece atribuir um peso excessivo à terminologia legislativa. M.

\footnotetext{
${ }^{585}$ M. SANTORINI, Invalidità delle delibere cit. (nota 578 supra), p 15.

586 “Art. 1418 Cause di nullità del contratto

Il contratto è nullo quando è contrario a norme imperative, salvo che la legge disponga diversamente.

Producono nullità del contratto la mancanza di uno dei requisiti indicati dall'art. 1325, l'illiceità della causa (1343), l'illiceità dei motivi nel caso indicato dall'art. 1345 e la mancanza nell'oggetto dei requisiti stabiliti dall'art. 1346.
}

Il contratto è altresì nullo negli altri casi stabiliti dalla legge (190, 226, 458, 778 e seguente, 780 e seguente, 788, 794, 1261, 1344 e seguente, 1350, 1471, 1472, 1895, 1904, 1972)."

587 “Art. 2.379 Deliberazioni nulle per impossibilità o illiceità dell'oggetto

Alle deliberazioni nulle per impossibilità o illiceità dell'oggetto si applicano le disposizioni degli artt. 1421, 1422 e 1423 (2486; att. 209)."

${ }^{588}$ M. SANTORINI, Invalidità delle delibere cit. (nota 578 supra), pp. 16-22. Normalmente a proteção criada pela nulidade consiste na possibilidade de limitar o comportamento que o ato nulo queria lhe impor. Essa defesa mediante inexecução é provavelmente a razão de subsistência da nulidade como categoria, o que suscita perplexidades à sua exclusão do horizonte das associações. $O$ autor analisa se a invalidade contemplada pelo artigo 23 do código contempla todas as hipóteses ou se restariam excluídos os casos de nulidade. Alguns doutrinadores sustentam que os casos de impossibilidade e ilicitude do objeto, contrariedade a normas imperativas ou à ordem pública e bons costumes estariam excluídos da disciplina do art. 23. As anomalias de procedimento estariam sujeitas ao artigo, e para as outras se aplicaria a disciplina de invalidade do negócio. Essa posição ganha força com a referência ao art. 2.379 das S.A. O fato da nulidade não ser expressamente mencionada pela lei não significa necessariamente que essa não possa ocorrer. Suspensão da deliberação seria própria para casos de deliberações nulas. Entre os casos de nulidade existem a constituição inadequada da assembleia ou a ausência de formação da maioria, casos em que falta uma vontade juridicamente imputável à associação. A nulidade poderia ocorrer ainda quando a deliberação existe, mas com objeto impossível ou ilícito. Existe uma opinião divergente. A nulidade ocorreria em casos de deliberações viciadas na sua formação, como a ausência de convocação de todos os associados, a falta de presença do número legal, a deliberação tomada por maioria simples e não qualificada. Não estariam incluídas no art. 23 e seriam disciplinadas pelos princípios gerais. A falta de correspondência entre a hipótese legislativa e a situação do caso concreto determinaria a inexistência da deliberação. Já a anulação caberia para todos os casos de anomalias não procedimentais, inclusive os casos de impossibilidade e ilicitude do objeto, contrariedade a normas imperativas ou à ordem pública e bons costumes. Outros doutrinadores defendem que todos os casos de invalidade estariam sujeitos à anulação, ou seja, o artigo 23 conduziria à anulação de atos que de acordo com o direito comum seriam hipóteses de nulidade. 
SANTORINI defende que não se deve fazer apenas uma interpretação lógica no caso, bem como discorda daqueles que entendem que houve uma derrogação aos princípios negociais gerais $^{589}$.

Existem, portanto, hipóteses de nulidade das deliberações das associações, disciplinadas de acordo com os princípios gerais dos contratos, reconhecendo-se que um problema de tutela do terceiro de boa-fé se refere também ao ato nulo ${ }^{590}$.

O projeto do Código Civil italiano parecia tratar de um só aspecto do problema da invalidade, negligenciando a hipótese de nulidade. Mas para alguns deveria ser admitida a possibilidade de nulidade de deliberações contrárias à ordem pública e aos bons costumes, em conformidade com o resto dos princípios reconhecidos em matéria de negócios ilícitos. O mesmo deveria valer para deliberações contrárias à lei, no caso de normas inderrogáveis ${ }^{591}$.

Percebeu-se que o legislador regula de forma insuficiente a hipótese de nulidade, além de limitá-la aos casos previstos em lei. Os intérpretes têm se socorrido do conceito da inexistência, que também trouxe dificuldades. Não se pode considerar simplesmente que foi prevista uma anulação em sentido técnico para as deliberações das associações. A intenção do legislador não foi banir a nulidade da vida dessas entidades, talvez não tendo apenas conseguido se exprimir de forma adequada ${ }^{592}$.

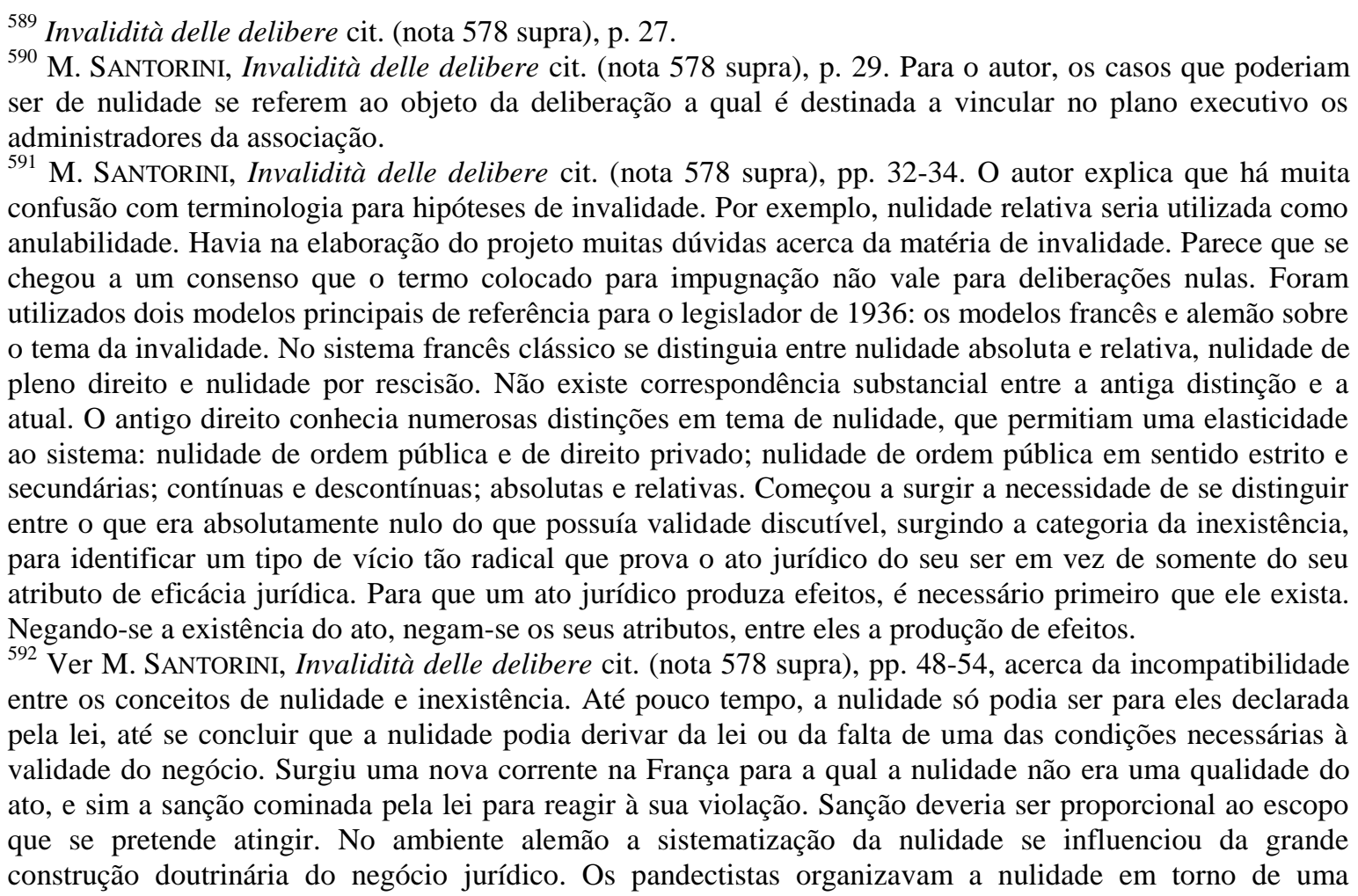


Uma corrente importante da doutrina italiana ${ }^{593}$ demonstrou que a contraposição entre nulidade e anulação deve ser repensada, sendo ilusório pensar que opondo nulidade uma a outra se possa traçar com precisão o divisor de águas entre o lado das invalidades insanáveis, imprescritíveis, e as sanáveis, prescritíveis, não invocáveis ex officio e somente pela parte protegida ${ }^{594}$.

Por outro lado, estudos mais recentes destacaram a incerteza e a relatividade dos critérios de distinção entre as duas categorias da anulação e nulidade. A disciplina do procedimento interno das corporações privadas e, portanto, da validade das deliberações, não pode ter o efeito de tornar legítimo o ato final de sua execução quando o conteúdo do ato for contrário a normas proibitivas. Um princípio não expresso, mas presumível no ordenamento jurídico italiano, é que o campo patrimonial dos associados não pode, em nome das entidades, praticar atos que não seriam válidos se exercidos individualmente ${ }^{595}$.

Parece que o legislador italiano, analisando-se o teor do citado artigo 23, quis ressaltar a necessidade do ajuizamento de ação em juízo para suspender a eficácia da deliberação ou para eliminá-la definitivamente, podendo excepcionalmente intervir a autoridade administrativa ${ }^{596}$.

A situação do terceiro de boa-fé se altera conforme a deliberação seja nula ou anulável, e se for ou não executada. Para tanto, é necessário aprofundar a distinção entre os momentos deliberativos e executivos da deliberação. A sua eficácia da deliberação se apresenta em dois aspectos: aquele da validade aparente, no que se refere à sua elaboração interna, e aquele da validade intrínseca em relação à conformidade com o ordenamento

bipartição, negócio nulo e anulável. Savigny começou o movimento sustentando que todos os atos nulos eram insanáveis, e todos os atos impugnáveis podiam ser sanados. Assim, o negócio nulo era o negócio incapaz de produzir efeitos, não sendo necessária nenhuma ação para excluir a sua eficácia, enquanto no caso do negócio anulável era necessária a reação da parte interessada. Todos podem invocar a nulidade, enquanto apenas alguns legitimados podem invocar a anulação. O juiz pode declarar a nulidade de ofício. Apenas a anulação é sanável. Se foi determinado por alguns estudiosos franceses que a nulidade pode derivar de disposições legais ou da falta de um requisito essencial do ato ou do negócio, é necessário determinar quais sejam os requisitos essenciais do ato ou do negócio válidos. Isso foi feito pela doutrina alemã, que trabalhou na elaboração de um conceito, o que foi evitado pelos franceses. Nenhum dos dois modelos foi transposto no direito italiano no estado puro, mas cada um dele sofreu uma série de adequações e distorções.

${ }^{593}$ Ver M. SANTORINI, Invalidità delle delibere cit. (nota 578 supra), p. 57. Cita-se em especial Rodolfo Sacco.

${ }^{594}$ Ver M. SANTORINI, Invalidità delle delibere cit. (nota 578 supra), p. 54. A doutrina italiana, primeiro inspirada pela francesa, voltou-se para a alemã, acerca da demarcação entre nulidade e anulação. O primeiro livro do Código Civil (PJ) foi inspirado ainda apelos franceses, falando de nulidade absoluta e relativa, enquanto a parte das obrigações foi inspirada pelos alemães, falando de nulidade e anulação. Esta indicação histórica confirma que quando o artigo 23 fala em anulação, não se pode atribuir o significado técnico dado depois à categoria de anulação.

${ }_{595}$ Ver M. SANTORINI, Invalidità delle delibere cit. (nota 578 supra), p. 59.

${ }^{596}$ Ver M. SANTORINI, Invalidità delle delibere cit. (nota 578 supra), p. 59. 
vigente. Em relação ao primeiro aspecto, conduz-se à tutela dos direitos adquiridos pelo terceiros, enquanto o segundo entra no tema da invalidade dos atos jurídicos privados, ou seja o tratamento da deliberação contrária à ordem pública, aos bons costumes ou a normas imperativas, segundo os princípios gerais da invalidade do atos jurídicos ${ }^{597}$.

Deve-se considerar a anulação ou nulidade em dois momentos distintos: a sua tomada e a sua execução. Do ponto de vista interno, os problemas que surgem se relacionam às anomalias de procedimento. Do ponto de vista externo, por outro lado, há o problema da conformidade aos princípios fundamentais do ordenamento jurídico: a questão da ilicitude, da contrariedade aos bons costumes e a normas imperativas da deliberação executada. Enquanto permanecer no âmbito interno essa vontade da maioria dos associados de praticar atos ilícitos em nome da associação pode suscitar apenas o problema de impedir que aquela deliberação seja traduzia em um ato executivo. Já a sua validade intrínseca como ato improdutivo de efeitos emerge no momento em que o ato é expresso na vida social através da ação daqueles a que é demandada a execução ${ }^{598}$.

O referido artigo 23 trata apenas do problema da invalidade da deliberação no seu aspecto interno - invalidades procedimentais - deixando de fora os problemas inerentes ao ato praticado. O legislador tentou impedir a execução do ato viciado, porque é contrário a normas imperativas, à ordem pública e aos bons costumes. Contudo, o recurso aos princípios gerais em matéria de invalidade quanto às anomalias procedimentais já é um meio de prevenção à execução, enquanto a nulidade não produz efeito algum e não vincula o órgão executivo ao cumprimento de um ato intrinsicamente nulo. Para os defeitos considerados mais graves, a tutela preventiva não se dá apenas em relação aos efeitos da nulidade, como também foi estabelecida a possibilidade de suspensão mediante a intervenção da autoridade governativa ${ }^{599}$.

Podemos concluir que as hipóteses de ilicitude ou impossibilidade do objeto da deliberação também estariam incluídas no artigo referente à anulação das deliberações, lembrando que quando se fala em anulação, não se trata, necessariamente, do sentido técnico. Isso ocorre porque a intenção do legislador foi impedir a execução da deliberação. Para as associações o legislador consentiu apenas a suspensão administrativa da

\footnotetext{
${ }^{597}$ Ver M. SANTORINI, Invalidità delle delibere cit. (nota 578 supra), pp. 60-61.

${ }^{598}$ Ver M. SANTORINI, Invalidità delle delibere cit. (nota 578 supra), p. 62.

${ }^{599}$ Ver M. SANTORINI, Invalidità delle delibere cit. (nota 578 supra), pp. 62- 63.
} 
deliberação com objeto ilícito, remetendo a questão à autoridade judiciária mediante provocação do Ministério Público ${ }^{600}$.

É necessária, portanto, uma coerência entre a invalidade do ato examinado e da deliberação que determina a sua execução. A disciplina da sua validade não pode produzir o efeito de tornar legítimo o ato final de execução delas, enquanto o conteúdo desse, que reflete o conteúdo daquela, for contrário às normas imperativas. $\mathrm{O}$ ato de execução contrário a normas imperativas atinge a sua própria execução. Se a concretização da deliberação pelo ato comporta improdutividade de efeitos do ato contrário a normas imperativas, à ordem pública e aos bons costumes, ou com objeto impossível, a deliberação da assembleia não poderá ser meramente anulável, mas deverá ser nula ${ }^{601}$.

A disciplina é distinta para negócios com conteúdo patrimonial e negócios de conteúdo não patrimonial. Nos contratos e negócios com conteúdo patrimonial se fortalece a tutela do possuidor e parece enfraquecida a relevância das razões de invalidade, enquanto que nos negócios não patrimoniais, em especial nos deliberativos de comunidades organizadas, emerge a necessidade de tornar tangível o ato de execução praticado com base em uma deliberação inválida, sendo necessário distinguir entre violação de normas proibitivas externas e de normas do estatuto. As deliberações contrárias ao estatuto eram sempre anuláveis, tratando-se a garantia dos associados de forma procedimental ${ }^{602}$.

M. SANTORINI ressalta que F. GALGANO sustentou que o referido artigo 23 fala de anulação em sentido técnico, sendo aplicável para as deliberações inválidas a disciplina de anulação do contrato. Para ele essa consequência só é aceitável se for admitida a premissa de que a garantia dos direitos adquiridos pelos terceiros de boa-fé ocorre, unicamente, no interno da categoria de atos anuláveis, e nunca no interno da dos atos nulos. Contudo, o problema da tutela dos terceiros de boa-fé ocorre também em relação a atos nulos. Considera-se, então, compreendida na tutela de terceiros do parágrafo $2^{\circ}$ do artigo 23 também a hipótese de violação de normas proibitivas. Portanto, quanto à proteção de terceiros de boa-fé relativa à deliberação executada, o remédio é o da anulação

\footnotetext{
${ }^{600}$ Ver M. SANTORINI, Invalidità delle delibere cit. (nota 578 supra), p. 64 . O mesmo ocorre em artigos sobre fundações, utilizando o legislador o termo anulação muitas vezes para casos clássicos de nulidade.

${ }^{601}$ Ver M. SANTORINI, Invalidità delle delibere cit. (nota 578 supra), p. 66.

${ }^{602}$ Ver M. SANTORINI, Invalidità delle delibere cit. (nota 578 supra), p. 69.
} 
para vícios procedimentais, enquanto para deliberações realizadas com objeto contrário a normas imperativas, à ordem pública e aos bons costumes, o remédio é outro ${ }^{603}$.

Sendo assim, os reflexos do que invalidamente foi praticado no interno do ente não podem prejudicar a posição do terceiro que celebrou negócio com a associação através dos seus órgãos representativos, com base na anomalia do procedimento. Mas quando se tratar de deliberação contrária à norma imperativa, à ordem pública e aos bons costumes, praticada pelo representante da entidade em conformidade com a deliberação, a tutela do terceiro de boa-fé não é mais ligada aos princípios operantes para as anomalias de procedimento interno, e sim se conecta àqueles da tutela da boa-fé do terceiro operantes no campo dos negócios patrimoniais, que possuem um papel oposto à relevância da aparência para as comunidades organizadas ${ }^{604}$.

$\mathrm{O}$ autor sustenta que no caso em que a invalidade se referir a normas proibitivas, a tutela do terceiro contratante segue as regras do ato praticado. Não se pode, portanto, incluir no mencionado artigo 23 , em respeito a tutela de terceiros, também os casos de deliberações nulas, contrárias à ordem pública, a normas imperativas e aos bons costumes. Não se pode considerar anulável o ato de execução de uma deliberação contrária a normas proibitivas, aplicando-se o remédio da nulidade. Não se pode, também, concluir que tudo recaia na hipótese da anulação e à sua inoponibilidade ao terceiro ${ }^{605}$.

Para A. CARLo no caso de deliberações assembleares constitui nulidade apenas as hipóteses de ilicitude ou impossibilidade do objeto. Já a violação da lei ou do estatuto gera simples anulação. O poder de anulação caduca após 3 meses da tomada da deliberação, independente do fato do titular do poder conhecer ou não o vício que afeta a deliberação. Trata-se de regime distinto dos princípios contratuais, justificado com a necessidade de tutelar a certeza das relações jurídicas e do tráfico. As deliberações assembleares (que não são contratos) produzem efeitos em uma esfera muito mais ampla que aquela de um contrato bilateral: a estabilidade da vida social e o interesse de terceiros

\footnotetext{
${ }^{603}$ Ver M. SANTORINI, Invalidità delle delibere cit. (nota 578 supra), p. 71. O terceiro que contratou com uma comunidade organizada e não com um particular não deve ser colocado em uma situação mais favorável em relação a que teria se tivesse contratado com o particular. As questões internas do grupo não devem condicionar a eficácia do ato a relevância externa. Mas estranho a esse princípio são os casos de atos contrários a normas imperativas e eventualmente com objeto impossível. Antigamente não era concebível uma violação da ordem pública através de violações de normas internas do ente. O correto seria tornar o mais seguro possível através de normas jurídicas a aquisição de terceiros das comunidades e não somente contar com a proteção através da nulidade. O instrumento técnico legislativo a ser empregado é o da tutela da aparência, ou melhor, daquele que confie na aparência.

${ }_{604}$ Ver M. SANTORINI, Invalidità delle delibere cit. (nota 578 supra), pp. 76-77.

${ }^{605}$ Ver M. SANTORINI, Invalidità delle delibere cit. (nota 578 supra), p. 77.
} 
que tenham contratado com a sociedade ou associação após uma deliberação seriam comprometidos se esta deliberação fosse impugnável depois de muitos anos. Explica, também, a degradação das causas de nulidade (que não prescrevem) em relação às causas de anulação, sujeitas a um brevíssimo termo de decadência ${ }^{606}$.

Vemos que as deliberações das associações podem ser anuláveis ou nulas, condição que depende do vício existente. Aquelas contrárias à lei e aos estatutos são anuláveis. Já as tomadas por órgãos sem poderes, por constituição inadequada da assembleia ou por um quorum menor que o previsto, como maioria ao invés de unanimidade, ou por ausência da formação da maioria, serão nulas. As deliberações com objeto ilícito, contrárias à ordem pública e aos bons costumes, bem como as ilícitas, que violarem normas inderrogáveis, ou visarem a excluir ou contornar a sua aplicação, também serão nulas.

As hipóteses de deliberações tomadas em conflito de interesses serão tratadas no subitem seguinte.

IV.4. Conflito de interesses

M. BASILE defende que se aplica aos administradores das associações a disciplina de conflito de interesses existente para as sociedades anônimas ${ }^{607}$.

Entendemos que a disciplina do conflito de interesses das sociedades anônimas deve ser aplicada não só para os administradores, como também para os associados dessas entidades ${ }^{608}$.

\footnotetext{
${ }^{606}$ Cf. A. CARLO, Il contratto plirilaterale cit. (nota 273 supra), pp. 262-263.

${ }^{607}$ Persone giuridiche cit. (nota 54 supra), pp. 241-242.

${ }^{608}$ Ver o artigo 115 da Lei das Sociedades Anônimas: "O acionista deve exercer o direito a voto no interesse da companhia; considerar-se-á abusivo o voto exercido com o fim de causar dano à companhia ou a outros acionistas, ou de obter, para si ou para outrem, vantagem a que não faz jus e de que resulte, ou possa resultar, prejuízo para a companhia ou para outros acionistas.

$\S 1^{\circ} \mathrm{O}$ acionista não poderá votar nas deliberações da assembleia-geral relativas ao laudo de avaliação de bens com que concorrer para a formação do capital social e à aprovação de suas contas como administrador, nem em quaisquer outras que puderem beneficiá-lo de modo particular, ou em que tiver interesse conflitante com o da companhia.

$\S 2^{\circ}$ Se todos os subscritores forem condôminos de bem com que concorreram para a formação do capital social, poderão aprovar o laudo, sem prejuízo da responsabilidade de que trata o $\S 6^{\circ}$ do artigo $8^{\circ}$.

$\S 3^{\circ} \mathrm{O}$ acionista responde pelos danos causados pelo exercício abusivo do direito de voto, ainda que seu voto não haja prevalecido.
} 
Sendo assim, quando o membro não for independente em relação à matéria discutida na assembleia, podendo influenciar nas decisões ou tomá-las motivado por interesses distintos daqueles da associação, não deverá participar da deliberação.

O associado deve, preferencialmente, informar a existência de interesses em conflito e se afastar da votação, pois as deliberações devem ser sempre tomadas no interesse do ente, e não de acordo com os objetivos de determinado membro.

F. C. PONTES DE MiRANDA explica que devem ser excluídos da votação nas assembleias os associados que participarem do negócio jurídico objeto da deliberação, ou que possam auferir determinado benefício com a sua aprovação, ou ainda quando a deliberação versar sobre negócio jurídico, de direito material ou processual, com ele ${ }^{609}$.

Portanto, aplicando-se a disciplina das sociedades anônimas em matéria de conflito de interesses às associações, considera-se abusivo o voto exercido pelo associado, com o fim de causar dano à entidade ou a outros membros, ou de obter, para si ou para outrem, vantagem a que não faz jus e de que resulte, ou possa resultar, prejuízo para o ente ou para outros membros. O associado responde pelo exercício abusivo do seu direito de voto, ainda que ele não tenha prevalecido.

A deliberação tomada em decorrência do voto do associado que possuir interesse conflitante com o da associação é anulável, respondendo o mesmo pelos danos causados e sendo obrigado a transferir para a entidade as vantagens que tiver auferido.

Os administradores do ente não poderão votar nas deliberações referentes à sua responsabilidade ou intervir naquelas que possuírem interesse conflitante com o da associação.

O administrador somente poderia contratar com a entidade em condições razoáveis ou equitativas, idênticas às que prevaleceriam no mercado ou em que se operariam com terceiros, sob pena de anulação do negócio, obrigando-se o gestor a transferir ao ente as vantagens que tiver auferido ${ }^{610}$.

Portanto, as deliberações tomadas em conflito de interesses, dos associados ou dos administradores, serão anuláveis.

$\S 4^{\circ}$ A deliberação tomada em decorrência do voto de acionista que tem interesse conflitante com o da companhia é anulável; o acionista responderá pelos danos causados e será obrigado a transferir para a companhia as vantagens que tiver auferido."

${ }^{609}$ Tratado de Direito Privado cit. (nota 4 supra), p. 383.

${ }^{610}$ Ver artigo 156 da Lei das Sociedades Anônimas. 
IV.5. Órgãos administrativos. A diretoria e o conselho de administração ou supervisão. Composição, competência, funções, eleição e destituição. Tomada e impugnação de deliberações

O estatuto das associações deve estabelecer o modo de constituição e de funcionamento dos órgãos deliberativos, bem como a forma de gestão administrativa ${ }^{611}$.

Como já mencionado, compete privativamente à assembleia geral especialmente convocada para esse fim - destituir os administradores cujo quorum será estabelecido no estatuto, que também deve determinar os critérios para a sua eleição ${ }^{612}$.

Nas associações a assembleia e a diretoria são órgãos obrigatórios, podendo ainda haver um conselho deliberativo ou de administração, subordinado à assembleia.

A diretoria é o órgão responsável pelo funcionamento da associação, dirigindo-a de acordo com as normas contidas no estatuto ${ }^{613}$.

Para F. C. Pontes dE MiRAnda a diretoria é um órgão necessário que administra a pessoa jurídica, de acordo com as instruções dadas pela assembleia. É o órgão executivo da associação, composto normalmente por associados, tornando-se o diretor nomeado órgão da pessoa jurídica ${ }^{614}$.

As deliberações são normalmente tomadas pelo princípio majoritário, salvo se o estatuto estabelecer de forma diversa. Os diretores podem ser destituídos pela assembleia, por unanimidade, ou por maioria, desde que previsto, operando a destituição ex nunc. Se o ato constitutivo nada designar acerca de sua representação, ela será exercida pela diretoria $^{615}$.

Considerando que faltam nas associações regras semelhantes às sociedades no tocante aos administradores, a doutrina teve que preencher as lacunas do ordenamento e chegou à conclusão que a assembleia pode intervir sobre os gestores, seja fixando diretrizes gerais, seja com ordens concretas acerca do cumprimento de determinada

\footnotetext{
${ }^{611}$ Ver artigo 54, incisos V e VII, do Código Civil.

${ }^{612}$ Ver artigo 59, inciso I e parágrafo único, do Código Civil.

${ }^{613}$ Cf. M. H. DinIZ, Curso de Direito cit. (nota 13 supra), p. 254.

${ }^{614}$ Tratado de Direito Privado cit. (nota 4 supra), pp. 387-391.

${ }^{615}$ F. C. PONTES DE MIRANDA, Tratado de Direito Privado cit. (nota 4 supra), p. 414.
} 
operação, podendo, ainda, atribuir a si a administração completa, delegando a eles a função de executar as suas deliberações ${ }^{616}$.

Em relação à composição do órgão, aos administradores das associações reconhecidas italianas - que não necessitam a princípio ser membros - é atribuída à natureza de mandatários do grupo. Nas não reconhecidas há uma disposição que impõe aos gestores uma responsabilidade pessoal pelas obrigações da entidade. Por estarem sujeitos aos riscos da administração, sustenta-se que são investidos de uma competência exclusiva para administrar. F. GALGANO defende que como são aplicadas normas das associações reconhecidas para as não reconhecidas, o inverso também pode ser feito. Conclui que nas primeiras, assim como nas segundas, deve haver uma gestão responsável, concedendo-lhe uma competência originária e exclusiva de administrar ${ }^{617}$.

Caberá à assembleia nomear e destituir os administradores, controlar a sua gestão e promover ação de responsabilidade em face deles. Não poderá, contudo, dar instruções específicas sobre determinadas operações, nem se opor à sua execução ${ }^{618}$.

O autor, de forma contrária a parte da doutrina italiana, defende que nas associações reconhecidas não poderá o terceiro que não seja membro, exercer os poderes inerentes aos administradores. Os gestores possuem poderes soberanos, não lhe parecendo aconselhável que tais poderes sejam exercidos por pessoas que não sejam membros ${ }^{619}$.

Os diretores são investidos de uma competência exclusiva para administrar, não limitável pela assembleia, que não pode invocar para si a gestão ou dar diretrizes para cada operação. Eles não se podem dizer vinculados à entidade por um contrato de mandato ou de trabalho subordinado. Seus poderes devem ser concebidos como originários, ou seja, poderes que, como órgãos necessários da execução do contrato de associação, derivam do contrato, da mesma forma que dele se originam os poderes da assembleia de membros. $\mathrm{O}$ contrato também impõe aos administradores obrigações correspectivas, a partir do momento em que eles se sujeitam, aceitando a nomeação, ao estatuto da entidade ${ }^{620}$.

A nomeação dos gestores, seguida de sua aceitação não é, para F. GALGANO, um negócio de atribuição de poderes, e sim um ato que designa as pessoas propostas ao

\footnotetext{
${ }^{616}$ Cf. F. Galgano, Persone giuridiche cit. (nota 57 supra), p. 258.

${ }^{617}$ Persone giuridiche cit. (nota 57 supra), pp. 258-259.

${ }^{618}$ Cf. F. GAlgANO, Persone giuridiche cit. (nota 57 supra), pp. 258-260.

${ }^{619}$ Persone giuridiche cit. (nota 57 supra), p 263. O entendimento adota a mesma regra vigente para as cooperativas, em razão da presença de um interesse de série ou de categoria em ambas, afastando-se das regras de administração das sociedades por ações.

${ }^{620}$ Cf. F. Galgano, Persone giuridiche cit. (nota 57 supra), pp. 290-291.
} 
órgão e que possuem a função legal de dar execução ao contrato. Uma vez escolhidas, essas pessoas exercem os poderes e cumprem as suas obrigações, inerentes à função que é própria do órgão a que são propostas ${ }^{621}$.

A gestão deve ser exercida no interesse da associação, de acordo com os seus fins. Para M. BASILE a garantia de que ela corresponda aos objetivos perseguidos pela entidade é feita por uma disciplina que prescreve os modos e o conteúdo dos atos, contida apenas em pequena parte no Código italiano e principalmente em princípios gerais ${ }^{622}$.

Como já salientado por F. GALGANO e também reconhecido por M. BASILE, existe uma lacuna acerca de como o órgão administrativo deve atuar no exercício das próprias competências, havendo, para alguns, um reenvio à autonomia privada. Em primeiro lugar existe o princípio da colegialidade, que pressupõe um órgão formado por vários indivíduos, devendo ser assegurada ao ente uma gestão unitária e fruto do exercício coletivo das funções. Este princípio comporta o direito-dever de cada administrador de concorrer à atividade deliberativa de pertinência ao conselho, excluindo poderes de administração disjuntiva ${ }^{623}$.

O Código italiano não restringe a competência dos gestores à prática de atos ordinários. O legislador se preocupa em estabelecer algumas obrigações mais importantes, bem como determinar que eles atuem com a diligência do mandatário. Devem cumprir os procedimentos e obter as informações necessárias ao bom êxito das iniciativas tomadas, não praticando atos que pareçam temerários ou arriscados. Os resultados obtidos na reconstrução do dever de diligência em matéria societária parecem ser aplicáveis aos diretores das associações, com o cuidado de se adaptar a circunstâncias diversas que possam ser relevantes em matéria associativa ${ }^{624}$.

Para M. BASILE os administradores devem se vincular com cautela às deliberações assembleares tomadas em matéria de gestão e atos determinados, em especial em relação àquelas com dúvidas de validade, comportando o seu dever de diligência um exame sobre isso. Justamente em razão dos deveres de lealdade e diligência imputados ao gestor, ele não deve praticar atos que possam gerar danos à associação, podendo convocar

\footnotetext{
${ }^{621}$ Persone giuridiche cit. (nota 57 supra), p. 292.

${ }^{622}$ Le persone giuridiche cit. (nota 54 supra), p. 240.

${ }^{623}$ Le persone giuridiche cit. (nota 54 supra), pp. 240-241.

${ }^{624}$ M. BASILE, Le persone giuridiche cit. (nota 54 supra), pp. 243-244.
} 
uma assembleia para resolver o problema, com o intuito de revogar ou modificar a deliberação, ou ainda de impugná-la imediatamente ${ }^{625}$.

A impugnação judicial das deliberações dos órgãos administrativos não era, inicialmente, admitida pela jurisprudência. Adotava-se o que se usava para as sociedades, entendendo-se que como havia omissão acerca da impugnação judicial de deliberações do conselho de administração, permitia-se tal contestação apenas em caso de conflito de interesses de um dos gestores, se gerasse danos à sociedade ${ }^{626}$.

Começou-se, posteriormente, a admitir impugnações por parte dos sócios e administradores, quando as deliberações do conselho fossem diretamente lesivas aos seus direitos. Depois houve uma regulamentação que permitiu a contestação por parte do conselho fiscal ou por gestores ausentes ou dissidentes de deliberações contrárias à lei ou ao estatuto e aos associados, podendo impugnar tais deliberações contrárias aos seus direitos. A contestação das deliberações do conselho das associações foi sendo admitida, mesmo das não reconhecidas, podendo ser feita de forma ampla por membros e gestores. A impugnação é atualmente admitida também para deliberações de outros órgãos ${ }^{627}$.

Para as deliberações dos conselhos das associações valem, em primeiro lugar, os princípios que dispõem acerca da nulidade de negócios praticados na ausência dos requisitos essenciais, ou em contraste com normas inderrogáveis. Usando a experiência societária, alguns afirmam que para essas entidades é aplicável a disciplina sobre a anulação das deliberações assembleares por analogia. Um limite para a impugnação poderia ser em relação a deliberações tomadas com discricionariedade, sustentando-se que o órgão de gestão é o único intérprete dos seus interesses, não podendo submeter suas razões ao judiciário. $\mathrm{O}$ autor discorda de tal posição, pois são admitidas as impugnações judiciais a deliberações de assembleias, mesmo sendo esses órgãos soberanos, concluindo que o respeito à autonomia dos gestores não exige a inadmissibilidade do controle judicial sobre as suas iniciativas ${ }^{628}$.

Há dúvidas sobre a aplicação das normas sobre deliberações assembleares em relação aos sujeitos legitimados a impugná-las. Para as sociedades anônimas, legitimados são o conselho fiscal e os administradores ausentes ou dissidentes, enquanto os sócios podem impugnar as deliberações lesivas dos seus direitos. A decisão de fazê-lo é de

${ }^{625}$ Le persone giuridiche cit. (nota 54 supra), p. 246.

${ }^{626}$ Le persone giuridiche cit. (nota 54 supra), pp. 247-248.

${ }^{627}$ M. BASILE, Le Persone giuridiche cit. (nota 54 supra), pp. 247-249.

${ }^{628}$ M. BASILE, Le persone giuridiche cit. (nota 54 supra), pp. 249-250. 
competência da assembleia, ou de algum outro órgão interno. Para as associações, parece ser admitida impugnação de gestores. Os associados podem impugnar deliberações lesivas aos seus interesses, mas não se sabe se podem impugnar deliberações que violem um interesse coletivo. Existem diferenças entre as deliberações tomadas pela assembleia e pelo conselho, pois ambos possuem colocações diversas na estrutura do ente, e em relação à posição do associado, que faz parte da assembleia, mas não do conselho ${ }^{629}$.

F. KÜBLER explica que, no direito alemão, a associação atua por meio da diretoria, que é um órgão de caráter necessário. Pode ser composta por uma ou mais pessoas, que não necessitam ser membros da entidade. Se o estatuto não dispuser de forma diversa, a competência para a sua nomeação e destituição cabe à assembleia. Os estatutos podem estabelecer a possibilidade de nomear representantes especiais para que realizem, junto à diretoria, tarefas determinadas ${ }^{630}$.

A diretoria representa a associação em juízo e fora dele. Se for composta por vários membros, é suficiente a atuação da maioria para que a representação seja eficaz. Cabe aos estatutos modificar estas regras, limitando o poder de representação, regras que ganharão eficácia em relação ao terceiro apenas se forem inscritas no registro das entidades $^{631}$.

Também no âmbito das relações externas, cabe à diretoria executar as tarefas de gestão do ente. Se os estatutos não dispuserem de modo diverso, a diretoria está obrigada a executar o deliberado pela assembleia, bem como não pode limitar o poder de representação de um dos seus membros. Se não cumprir as instruções da assembleia ou infringir culposamente qualquer outra forma dos seus deveres de gestão, deverá ressarcir o dano causado ${ }^{632}$.

No direito francês, de acordo com Y. GUYON, a duração das funções dos dirigentes nas sociedades - o que se aplica para as associações -, é estabelecida em um mínimo e um máximo de tempo, no caso do mandato de diretor, entre 2 a 6 anos. A violação dessa disposição de caráter imperativo, acarreta a nulidade da nomeação. Na maioria das vezes, no entanto, a lei impõe apenas um período máximo, a fim de evitar a perpetualização dos gestores fundadores. Há outras sociedades em que a lei não impõe

\footnotetext{
${ }^{629}$ M. BASILE, Le persone giuridiche cit. (nota 54 supra), pp. 251-252.

${ }^{630}$ Derecho de Sociedades cit. (nota 61 supra), pp. 214-215.

${ }^{631}$ Ver F. KÜBLER, Derecho de Sociedades cit. (nota 61 supra), p. 215.

${ }^{632}$ Ver F. KÜBLER, Derecho de Sociedades cit. (nota 61 supra), pp. 215-216.
} 
limite algum para a duração da função dos administradores, que podem ser nomeados para toda a duração da entidade, como nas sociedades civis e em nome coletivo ${ }^{633}$.

Normalmente o órgão que nomeou o dirigente é competente para destituí-lo. No caso de algumas sociedades e das associações, os diretores normalmente são nomeados pelos associados e, também por eles, destituídos. Isso nem sempre ocorre. Nas sociedades anônimas fechadas, por exemplo, os primeiros administradores são designados no estatuto, podendo ser destituídos por uma assembleia geral ordinária, embora ela não tenha poderes para modificar o estatuto. Os membros da diretoria são nomeados pelo conselho de administração e destituídos pela assembleia geral. Em alguns casos a lei prevê uma destituição judicial, para sociedades civis, limitadas e acomandita por ações. O judiciário pode, por outro lado, proteger o administrador de uma destituição arbitrária dos $\operatorname{associados}^{634}$.

Por ocasião da constituição da sociedade ou da associação escolhe-se se a destituição dos administradores poderá ser injustificada ou se será necessária justa causa. Alguns dirigentes podem ser destituídos sem motivo, sem aviso prévio e sem indenização, enquanto outros só podem ser destituídos por justa causa. A forma motivada se tornou a causa, e a sem motivação a exceção, diferentemente do que ocorre com o mandato. $\mathrm{O}$ administrador injustamente destituído normalmente não é reintegrado, e sim tem direito a perdas e danos $^{635}$.

Em relação ao funcionamento do conselho de administração a lei francesa faz muita remissão aos estatutos para organizar o seu funcionamento. Eles devem fixar as regras relativas à convocação e às deliberações. Podem precisar as condições através das quais os gestores recebem ou tomam conhecimento das informações às quais têm direito. De acordo com a jurisprudência, a insuficiência de informações pode viciar as deliberações do conselho ${ }^{636}$.

As deliberações do conselho de administração normalmente não possuem o mesmo formalismo aplicado para aquelas das assembleias. Podem ainda existir estatutos

\footnotetext{
${ }^{633}$ Les Sociétés cit. (nota 126 supra), pp. 53-55.

${ }^{634}$ Cf. Y. GuYON, Les Sociétés cit. (nota 126 supra), pp. 55- 57.

${ }^{635}$ Cf. Y. GuYon, Les Sociétés cit. (nota 126 supra), pp. 57-61. O autor explica que as maiores dúvidas surgem a respeito do que se entende por justa causa para destituição. Poderia ser, por exemplo, uma falha no exercício de suas funções, um erro ou impedimento. Alguns alegam que agir sem ser de acordo com o interesse social poderia ser justa causa. A justa causa pressupõe uma certa gravidade.

${ }^{636}$ Cf. Y. GuYON, Les Sociétés cit. (nota 126 supra), pp. 193-194.
} 
ou os regulamentos internos do conselho com a função de precisar os deveres de diligência, de lealdade, de imparcialidade e de boa-fé que cabe aos gestores ${ }^{637}$.

Em relação ao funcionamento do conselho de administração, que é um órgão deliberante, existem regras legais menos rígidas, pois o essencial não é proteger os minoritários, e sim assegurar a eficácia das deliberações da equipe dirigente, composta muitas vezes de profissionais. Os sócios ou associados podem estabelecer muitas flexibilizações nesse campo, desde que não atentem contra o caráter colegial e deliberante do órgão. Os estatutos podem, contudo, exigir uma maioria mais forte que a absoluta, até prevendo a unanimidade para a tomada de determinadas decisões ${ }^{638}$.

Também no direito brasileiro existem lacunas no tocante ao funcionamento do órgão administrativo das associações, tendo a jurisprudência adotado algumas diretrizes.

A diretoria deve dirigir a entidade, de acordo com as regras escolhidas por seus associados, constantes do estatuto, e em assembleia. Sendo um órgão colegiado, as deliberações devem ser tomadas pelo princípio majoritário, a não ser que o estatuto disponha de forma diversa. A assembleia pode fixar diretrizes gerais para os administradores, sendo controvertido se podem dar ordens concretas para operações específicas.

Aos administradores das associações aplicam-se os deveres de diligência e lealdade contidos na lei das sociedades anônimas. Deve ser admitido aos associados, pelo menos, o direito de impugnar deliberações da diretoria contrárias aos seus interesses e aos gestores e conselheiros fiscais o direito de impugnar as deliberações contrárias à lei, aos estatutos, em caso de conflito de interesses dos administradores ou que possam gerar danos à associação. $\mathrm{O}$ estatuto deve estabelecer se a destituição dos dirigentes deverá ser motivada.

Destacamos, a seguir, alguns julgados referentes à representação e administração das associações. No caso de entidade que perde seu presidente, não conferindo a lei ou o estatuto tal representação a qualquer sócio, no período de vacância

${ }_{638}^{637}$ Cf. Y. GuYON, Les Sociétés cit. (nota 126 supra), pp. 193-194.

${ }^{638}$ Cf. Y. GuYON, Les Sociétés cit. (nota 126 supra), pp. 232-234. 
dos cargos, deve ser convocada uma assembleia geral extraordinária para eleição de novo quadro diretivo. ${ }^{639}$ Só podem ser eleitos para a administração associados adimplentes ${ }^{640}$.

Os procedimentos previstos no estatuto no tocante à administração devem ser seguidos. Não se pode, por exemplo, impedir um presidente eleito de uma associação de exercer o cargo, sob alegação de que teria cometido falta grave ao se ausentar da associação por determinado período, quando o estatuto exigir para a perda do mandato a ausência em três reuniões mensais da diretoria executiva, com a necessidade de convocação de assembleia específica para o fim ${ }^{641}$.

No caso de afastamento de diretores, não pode o presidente da associação aplicar penalidades sozinho, quando o estatuto estabelece procedimento diverso ${ }^{642}$.

A associação sem fins lucrativos não pode distribuir resultados, não podendo seus administradores receber valores indevidamente ${ }^{643}$.

IV.6. Responsabilidade dos administradores em face da associação, dos associados, dos credores e de terceiros

O artigo 47 do Código Civil brasileiro dispõe que os atos dos administradores obrigam a pessoa jurídica, desde que exercidos nos limites de seus poderes definidos no ato constitutivo. Contudo, na parte dedicada à disciplina normativa das associações, nada foi previsto especificamente acerca da responsabilidade dos administradores.

Portanto, o papel do ato constitutivo e do estatuto é essencial para se determinar como se dará a responsabilidade dos gestores, bem como se será cabível o ressarcimento de eventual dano causado por violação dos seus deveres, por prática de ato

\footnotetext{
${ }^{639}$ TJSP, $20^{\text {a }}$ Câm. de Dir.Priv., Apel. Cível n. 1061353-9, rel. Correia Lima, j. 22-5-2007.

${ }^{640}$ Ver o seguinte julgado: "Eleição de dirigentes de associação. Inelegibilidade de parte de seus integrantes, que estavam inadimplentes, impedindo que fossem votados". TJRS, $16^{\text {a }}$ Câm. Cível, Ag. n. 70041013590, rel. Ergio Roque Menine, j. 16-5-2011.

${ }^{641}$ TJSP, $1^{\text {a }}$ Câm. de Dir.Priv., Ag. n. 99010277117-2 , rel. Rui Cascaldi, j. 10-8-2010.

${ }^{642}$ Nesse sentido: "Impossibilidade de presidente da associação aplicar sozinho penalidades para afastar diretores, quando o estatuto dispõe da necessidade de aprovação pela diretoria e assembleia geral". TJSP, $7^{\mathrm{a}}$ Câm. de Dir. Priv., Apel. Cível n. 0019046-78.2000.8.26.0000, rel. Gilberto de Souza Moreira, j. 8-6-2011. ${ }^{643}$ Ver o seguinte julgado: "Presidente de associação que recebe valores indevidamente e emite instrumento de confissão de dívida da associação a seu favor de dívida inexistente. Condenação à restituição dos valores indevidamente recebidos". TJSP, $1^{\text {a }}$ Câm. de Dir. Priv., Apel. Cível n. 99407086968-0, rel. Rui Cascaldi, j. 24-8-2010.
} 
contrário à lei ou ao estatuto ou ainda por omissão. Por fim, cabe ainda analisar se as disposições das sociedades seriam aplicáveis subsidiariamente.

M. BASILE confirma que existe um dever de gestão dos administradores, em razão da responsabilidade deles em relação à associação pelos atos praticados, podendo ainda responder em face de terceiros ${ }^{644}$.

Os atos de gestão que não sejam praticados em conformidade com os deveres dos administradores ou a completa omissão daqueles devidos constituem inadimplemento. Se produzirem danos à associação, haverá obrigação de ressarci-los. Contudo, a obrigação surge somente se a execução pelos dirigentes era possível, ou ainda se se tornou impossível por um fato imputável a eles ${ }^{645}$.

Para o autor, a responsabilidade extracontratual só teria lugar se os administradores provocassem danos agindo fora da relação de gestão. Pode haver responsabilidade dos gestores por danos causados aos associados, na mesma forma que ocorre nas sociedades, e também por danos causados a terceiros, credores ou estranhos. Existem algumas peculiaridades, ligadas ao caráter colegial do órgão investido do poder de gestão, à indeterminação do seu conteúdo e ao papel subordinado do órgão administrativo em relação à assembleia ${ }^{646}$.

Assim, o caráter colegial do dever de gestão comporta que a sua inobservância seja um ilícito coletivo, ocorrendo inadimplemento de todos os membros do órgão. Há, contudo, exceções. Se for um ato comissivo, a responsabilidade é somente dos que agiram, mas aqueles que tinham ciência devem registrar a sua discordância para não serem responsabilizados. Para delegações o inadimplemento de alguns não se estende aos outros, que podem, porém, responder perante o ente por omissão de vigilância, nos limites do dano derivado de tal omissão ${ }^{647}$.

A indeterminação do dever de perseguir os interesses da associação acarreta uma análise, no caso concreto, da diligência empregada pelo administrador no ato para se avaliar se houve ou não descumprimento do dever. Os gestores respondem quando agirem com negligência. Devem agir de acordo com as diretivas tomadas legitimamente pela

\footnotetext{
${ }^{644}$ Le persone giuridiche cit. (nota 54 supra), p. 242.

${ }^{645}$ Ver M. BASILE, Le persone giuridiche cit. (nota 54 supra), p. 254.

${ }^{646}$ Ver M. BASILE, Le persone giuridiche cit. (nota 54 supra), pp. 254-255.

${ }^{647}$ Ver M. BASILE, Le persone giuridiche cit. (nota 54 supra), p. 255.
} 
assembleia, mas respondem se causarem danos por atos praticados em obediência a deliberações ilegítimas ${ }^{648}$.

É aplicável às associações a regra das sociedades de capitais segundo a qual a aprovação do balanço não libera os administradores de responsabilidade perante o ente $^{649}$.

De acordo com T. A. LOPES a principal função da responsabilidade civil é a compensação ou reparação de danos. O princípio básico é a reparação integral, a volta ao status quo ante, se possível ${ }^{650}$.

Segundo a autora, a teoria da responsabilidade civil atual está voltada para a proteção da vítima, prevalecendo a ideia de reparação do dano injusto ${ }^{651}$.

Nas associações, pode ocorrer que não seja possível o retorno à situação anterior, antes da prática do ato que causou dano à entidade, devendo a indenização, nesse caso, ser convertida em perdas e danos.

O dano a ser ressarcido compreende as perdas e o lucro cessante que forem consequência imediata e direta do inadimplemento. A obrigação dos administradores de ressarcimento é solidária. Valem os princípios gerais também para o exercício das ações de responsabilidade. Cabe à associação o ônus da prova do inadimplemento e do dano. Os gestores somente podem se eximir da condenação se demonstrarem a impossibilidade do adimplemento ou a sua independência em relação a ele ou a ausência de dano ${ }^{652}$.

Notamos, assim, que no direito italiano a questão da responsabilidade dos gestores das associações é disciplinada pelo legislador, contendo normas semelhantes àquelas que regulam a responsabilidade dos administradores das sociedades por ações.

Existem algumas peculiaridades acerca da responsabilidade dos administradores das associações não reconhecidas. De acordo com M. BESSONE a subjetividade dessas entidades faz com que as obrigações assumidas pelas pessoas que a

\footnotetext{
${ }^{648}$ Ver M. BASILE, Le persone giuridiche cit. (nota 54 supra), pp. 255-256.

${ }^{649}$ Ver M. BASILE, Le persone giuridiche cit. (nota 54 supra), p. 256.

${ }^{650}$ Princípio da Precaução e Evolução da Responsabilidade Civil, São Paulo, Quartir Latin, 2010, pp. 76-77.

651 Principais Linhas da Responsabilidade Civil no Direito Brasileiro Contemporâneo, in Revista da Faculdade de Direito da USP, v. 101, 2006, p. 119.

${ }^{652}$ Ver M. BASILE, Le persone giuridiche cit. (nota 54 supra), pp. 256-257.
} 
representam sejam próprias do ente. Contudo, respondem também pessoal e solidariamente todos aqueles que agirem em nome e por conta da associação ${ }^{653}$.

Nas associações não reconhecidas há, portanto, uma disposição que impõe aos administradores uma responsabilidade pessoal pelas obrigações da entidade. Por estarem sujeitos aos riscos da gestão, sustenta-se que os seus dirigentes são investidos de uma competência exclusiva para administrar ${ }^{654}$.

O artigo 18 do Código Civil italiano estabelece que os administradores são responsáveis perante a associação de acordo com as normas do mandato. Não possuirá responsabilidade o gestor que não houver participado do ato que causou o dano, salvo se tivesse conhecimento do que estava a ser executado e não manifestou a sua discordância.

Da mesma forma, para F. GALGANO, os gestores possuem a obrigação de ressarcir os danos causados à associação, com o descumprimento dos deveres inerentes à sua função. A ação de responsabilidade nessas entidades é deliberada pela assembleia e exercida pelos novos administradores ou liquidantes. A responsabilidade dos dirigentes é regulada com um reenvio às normas do mandato ${ }^{655}$.

Contudo, para o autor, se considerarmos que os administradores das associações forem subordinados às diretrizes da assembleia e investidos de uma competência originária e exclusiva de administrar, entende-se que, apesar da remissão às regras do mandato, essas normas possuem pouca possibilidade de aplicação, restringindose à utilização daquela referente à diligência do mandatário. A diligência que se requer do gestor é aquela normal e ordinária, e não uma especial. A responsabilidade dos dirigentes deverá, como aquela do mandatário, ser avaliada de forma menos rigorosa quando ele desempenhar a sua atividade de forma gratuita ${ }^{656}$.

$\mathrm{O}$ autor conclui que a responsabilidade dos administradores em face da associação possui natureza contratual. Para caracterizá-la não basta que tenha ocorrido um dano que seja imputável à sua conduta, devendo haver o descumprimento específico de uma obrigação imposta pela lei ou pelo ato constitutivo ou a falta de execução com a diligência prescrita. $\mathrm{O}$ dano sofrido pelo ente deve ser consequência imediata e direta desse descumprimento, não existindo responsabilidade do gestor só pelo fato dele integrar o

\footnotetext{
${ }^{653}$ Casi e questioni cit. (nota 254 supra), pp. 430-434.

${ }^{654}$ Casi e questioni cit. (nota 254 supra), pp. 434-435.

${ }^{655}$ Persone giuridiche cit. (nota 57 supra), p. 257.

${ }^{656}$ Persone giuridiche cit. (nota 57 supra), p. 257.
} 
conselho de administração. Ele deve ter participado do ato que causou o dano e, se não participou, não deve ter constado a sua divergência em relação ao ato que estava para ser praticado. Se a responsabilidade for de mais de um gestor, será solidária, podendo o ente agir em face de apenas um deles ${ }^{657}$.

Os administradores são ainda responsáveis em face dos credores da associação, respondendo, em especial, pelo prejuízo causado pela violação dos deveres inerentes à conservação da integridade do patrimônio do ente, o que configura lesão, por ato dos gestores, da expectativa de prestação dos credores. Além da ação de responsabilidade que cabe ao ente, os credores possuem outra ação em face dos administradores. De qualquer forma, se aplicam as disposições de responsabilidade por ato ilícito nessas relações, desde que haja nexo causal entre o dano e o comportamento lesivo $^{658}$.

Apesar de não haver norma expressa no Código Civil italiano, a pessoa jurídica é responsável perante terceiros pelos atos ilícitos que os seus representantes, administradores e prepostos praticarem, no exercício de suas funções, sem prejuízo da responsabilidade pessoal do culpado. Para justificá-la, F. GALGANO esclarece que se recorreu, tradicionalmente, ao conceito de "órgão": à relação definida, em contraposição com a de representação, como relação orgânica. Como o gestor também responde, alguns sustentaram que deveria ser afastada a ideia de órgão para se adotar a de representação, sendo a responsabilidade da pessoa jurídica indireta. Sendo assim, o administrador é concebido como órgão da pessoa jurídica e, ao mesmo tempo, se submete a uma responsabilidade pessoal pelo ato ilícito cometido no exercício das suas funções ${ }^{659}$.

As ações de responsabilidade contra os administradores das associações pelos atos por eles praticados serão deliberadas pela assembleia e exercidas pelos novos administradores ou liquidantes ${ }^{660}$.

F. KÜBLER explica que, no direito alemão, se a diretoria não cumprir as instruções da assembleia ou infringir culposamente qualquer outra forma dos seus deveres de gestão, deverá ressarcir o dano causado. Contudo, o órgão responde unicamente perante a associação, e não perante os associados ou credores, que não possuem legitimidade para ajuizar ações de responsabilidade em face dele. Para responsabilizá-los, a assembleia deve

\footnotetext{
${ }^{657}$ Persone giuridiche cit. (nota 57 supra), pp. 295-296.

${ }^{658}$ Cf. F. GAlgano, Persone giuridiche cit. (nota 57 supra), p. 296.

${ }^{659}$ Persone giuridiche cit. (nota 57 supra), pp. 301-303.

${ }^{660}$ Ver o artigo 22 do Código Civil Italiano.
} 
destituí-los, elegendo outra diretoria, cabendo a esta o direito de exigir uma indenização. Diferentemente do que ocorre com a sociedade anônima, a aprovação da gestão social significa necessariamente a perda de qualquer direito de exigir responsabilidade, pois tem a eficácia de uma renúncia ou de um reconhecimento de dívida em sentido negativo ${ }^{661}$.

A associação responde pelos atos ilícitos que gerem obrigação de indenizar cometidos pela diretoria, por algum de seus membros ou por outros representantes nomeados estatutariamente no exercício de suas funções. A responsabilidade é não só por atos ilícitos praticados, mas também aqueles previstos em qualquer norma de direito privado da qual derivem ações de indenização, inclusive por risco, por inadimplemento contratual e por danos causados a terceiros em virtude de atuações legítimas ${ }^{662}$.

Portanto, são aplicáveis às associações regras de responsabilidade dos gestores semelhantes àquelas existentes nas sociedades anônimas.

No que se refere às relações com terceiros, a jurisprudência parece propensa a conceder às associações muitas vantagens, em detrimento deles. O ônus da prova é atribuído aos terceiros que negociam com o ente ou que o demandarem em juízo, cabendo a eles identificar o representante da associação e verificar a legitimação de contratar ou de se defender no processo. De forma vantajosa para essas entidades a jurisprudência aplica ainda os princípios sobre a responsabilidade das obrigações associativas, sendo que na prática muitas vezes os terceiros fazem valer os seus direitos sobre o patrimônio das pessoas que agiram pelo grupo ${ }^{663}$.

IV.7. Órgãos de controle e de resolução de controvérsias internas

De acordo com M. BASILE, além da assembleia e do conselho de administração, o ato constitutivo e o estatuto das associações podem prever a criação de outros órgãos, determinando a sua composição e as suas competências, que podem ser retiradas daquelas confiadas pela lei às assembleias ou aos administradores. Trata-se de órgãos de disciplina e de justiça interna, sobre os quais surgem problemas de legitimidade

${ }^{661}$ Derecho de Sociedades cit. (nota 61 supra), pp. 215-216.

${ }^{662}$ Derecho de Sociedades cit. (nota 61 supra), p. 216.

${ }^{663}$ Ver M. BASILE, Associazioni cit. (nota 214 supra), pp. 220-222. 
e regulamentação. Podem ser previstos ainda órgãos de resolução de controvérsias internas $^{664}$.

Recentemente têm surgido na Itália normas que vinculam em alguns pontos a estrutura do ente, prescrevendo, por exemplo, órgãos de controles internos ${ }^{665}$.

As novas formas de controle dirigem-se aos organismos que perseguem escopos, desenvolvem programas ou assumem iniciativas de interesse geral. A justificativa é garantir a existência dos requisitos necessários para usufruir de certos benefícios previstos a seu favor ${ }^{666}$.

No Brasil, muitas associações são dotadas de um conselho fiscal. Para J. E. S. PAES, ele é um órgão essencial dessas entidades e tem como competência a fiscalização da sua gestão econômico-financeira ${ }^{667}$.

Podemos sustentar, assim, que o conselho fiscal nas associações deve fiscalizar os atos dos seus administradores e o cumprimento de seus deveres legais e estatutários. O órgão deverá, ainda, denunciar os erros, fraudes ou crimes que descobrir, e sugerir providências úteis ao ente.

Ao conselho fiscal deve ser garantido o acesso às atas de reuniões do conselho de administração e aos documentos contábeis, podendo solicitar aos gestores esclarecimentos ou informações, referentes à sua função fiscalizadora, bem como participar de reuniões dos órgãos dirigentes.

IV.8. Condições para alterações do estatuto

Tratamos, anteriormente, das matérias que devem integrar o conteúdo do estatuto das associações. Ele deve conter, como previsto no artigo 54 inciso VI do Código Civil, sob pena de nulidade, as condições para a alteração das suas disposições, sendo tais modificações de competência privativa da assembleia geral, conforme previsto no artigo 59 inciso II do mesmo Código.

\footnotetext{
${ }^{664}$ Le persone giuridiche cit. (nota 54 supra), p. 219.

${ }^{665}$ Le persone giuridiche cit. (nota 54 supra), p. 219.

${ }^{666}$ Le persone giuridiche cit. (nota 54 supra), p. 214.

${ }^{667}$ Fundações, Associações e Entidades cit. (nota 32 supra), p. 178.
} 
A assembleia deverá ser especialmente convocada para o fim de alterar o estatuto, que deverá estabelecer ainda o quorum necessário para efetuar tais modificações $^{668}$.

$\mathrm{Na}$ Itália o ato constitutivo e o estatuto das associações podem ser modificados por deliberação da assembleia. A alteração deve ser aprovada pela autoridade administrativa, como é feito por ocasião do registro, para garantir que continuem presentes os requisitos para o reconhecimento da personalidade do ente coletivo e não sejam alterados pelos associados ${ }^{669}$.

No Brasil, a modificação do ato constitutivo ou dos estatutos também deve obedecer às regras legais e estatutárias. Se houver regras legais cogentes, não cabem, no ponto regido por elas, regras estatutárias. Portanto, em relação à modificabilidade do estatuto das associações, é cogente a regra legal que determina ser de competência privativa da assembleia geral, especialmente convocada para esse fim, deliberar sobre as suas alterações, devendo o próprio estatuto conter o quorum necessário para a aprovação das modificações. Tratando-se de matéria tratada por norma dispositiva, o estatuto pode estabelecer o quorum que os associados entenderem apropriado para a tomada de tal deliberação ${ }^{670}$.

O ato constitutivo e os estatutos são criados por unanimidade, podendo, contudo, a maioria, ou dois terços dos associados ou ainda outro quorum previsto bastar para a sua modificação ${ }^{671}$.

Portanto, percebemos novamente que existe autonomia dos associados para dispor sobre o quorum que entenderem necessário para modificação das disposições estatutárias, desde que respeitem as normas legais sobre competência privativa da assembleia, que deverá ser especialmente convocada para o fim de deliberar sobre as alterações do estatuto. A lei não prevê nenhum quorum qualificado para a tomada de determinadas deliberações, mas os associados na prática o fazem com frequência, talvez

\footnotetext{
${ }^{668}$ Ver parágrafo único do artigo 59 do Código Civil.

${ }^{669}$ Cf. F. GALGANO, Persone giuridiche cit. (nota 57 supra), p. 285.

${ }^{670}$ Ver F. C. PONTES DE MIRANDA, Tratado de Direito Privado cit. (nota 4 supra), p. 379.

${ }^{671}$ Tratado de Direito Privado cit. (nota 4 supra), p. 380. O autor explica, contudo, que existem limites à alteração por menos que a unanimidade. Nesse sentido, qualquer alteração que viole o princípio da igualdade necessita de aprovação de todos os prejudicados com a aprovação, para proteger a minoria. Não se pode diminuir, por simples maioria, os direitos dos membros.
} 
em função da existência de normas cogentes para alguns tipos de sociedades e para as fundações $^{672}$.

Nas fundações, por exemplo, para alteração do estatuto, é necessário que a reforma seja deliberada por $2 / 3$ (dois terços) dos competentes para gerir e representar a entidade, além da necessidade de aprovação do Ministério Público ${ }^{673}$.

Nas sociedades simples existem determinadas matérias que só podem ser modificadas com o consentimento de todos os sócios, dentre elas o capital social, os poderes e atribuições dos administradores e as suas responsabilidades. Para as outras matérias, basta a aprovação da maioria absoluta dos votos, salvo se o contrato determinar a necessidade de deliberação unânime ${ }^{674}$.

Nas sociedades limitadas, as modificações do estatuto social também dependem de deliberações dos sócios, que deverão ser tomadas em assembleia ${ }^{675}$. Para modificação do contrato social são necessários votos correspondentes, no mínimo, a três quartos do capital social ${ }^{676}$.

Nas sociedades anônimas, é competência privativa da assembleia a reforma do estatuto social, devendo a deliberação ser tomada em assembleia geral extraordinária ${ }^{677}$. A assembleia-geral extraordinária que tiver por objeto a reforma do estatuto somente se instalará em primeira convocação com a presença de acionistas que representem 2/3 (dois terços), no mínimo, do capital com direito a voto, mas poderá instalar-se em segunda com qualquer número $^{678}$. É previsto, ainda, um quorum qualificado de acionistas que representem metade, no mínimo, das ações com direito a voto, se maior quorum não for exigido pelo estatuto da companhia, nas sociedades anônimas fechadas, para deliberação sobre algumas matérias, dentre elas alterações estatutárias como a mudança do objeto, fusão, incorporação ou cisão da companhia ${ }^{679}$.

\footnotetext{
${ }^{672}$ Ver J. E. S. PAES, Fundações, Associações e Entidades cit. (nota 32 supra), p. 169. O Código Civil exigia $2 / 3$ dos presentes para aprovação das alterações ao estatuto. Com a aprovação da Lei 11.127/05 faculta-se aos associados estabelecerem tanto o quorum quanto uma forma diversa de deliberação (inclusive ser de competência exclusiva da assembleia). Nesse ponto, discordo de F. C. PONTES DE MIRANDA, para quem a competência da assembleia não pode ser subtraída.

${ }^{673}$ Ver artigo 67, incisos I e III, do Código Civil.

${ }^{674}$ Ver artigo 999 do Código Civil.

${ }^{675}$ Ver artigo 1.071, inciso III, do Código Civil.

${ }^{676}$ Ver artigo 1.076, inciso I, do Código Civil.

${ }^{677}$ Ver artigos 122, inciso I, e 131 da Lei das Sociedades Anônimas.

${ }^{678}$ Ver artigo 135 da Lei das Sociedades Anônimas.

${ }^{679}$ Ver artigo 136, incisos IV, VI e IX, da Lei das Sociedades Anônimas.
} 
Y. GUYON explica que, no direito francês, em princípio as regras de maioria são fixadas pela lei, com caráter imperativo, de tal forma que não há lugar para a liberdade dos associados. A regra se aplica para as sociedades anônimas e limitadas, em caso de modificação dos estatutos, enquanto que nas sociedades civis a regra é diferente, pois as decisões coletivas são tomadas nas condições de quorum e de maioria fixadas pelos estatutos, sendo que somente na omissão de tais regras a unanimidade é necessária ${ }^{680}$.

No direito das sociedades, os associados muitas vezes desejam amenizar as regras de organização ou de funcionamento, por não se adequarem aos seus objetivos, mas sem sair dos modelos legais. Contudo, tais amenizações devem ter limites, para não provocar irregularidades $^{681}$.

À primeira vista, a liberdade dos associados nessas sociedades parece bastante limitada, uma vez que as alterações estatutárias ao regime legal devem respeitar a ordem pública, devendo os estatutos respeitar os direitos fundamentais e individuais dos membros, que muitas vezes são genéricos e imprecisos ${ }^{682}$.

As amenizações só serão válidas se respeitarem esses standards, devendo ser evitados os privilégios estatutários, porque a expressão invoca uma ruptura de igualdade injustificada e a sua validade será discutível. Em segundo lugar, não podem diminuir as garantias oferecidas a terceiros. Por fim, as alterações não podem modificar a hierarquia dos órgãos sociais ou ignorar a competência própria de cada um ${ }^{683}$.

Portanto, parece haver uma flexibilidade maior dos membros em relação às alterações dos estatutos das associações em comparação às sociedades, havendo poucas normas cogentes nesse sentido nas primeiras. Isso não significa que os associados, se entenderem adequado, não possam estipular quoruns qualificados para a alteração de determinadas matérias, tidas por eles como relevantes.

\footnotetext{
${ }^{680}$ Les Sociétés cit. (nota 126 supra), pp. 190-191.

${ }^{681}$ Cf. Y. GuYON, Les Sociétés cit. (nota 126 supra), p. 213.

${ }^{682}$ Cf. Y. GuYon, Les Sociétés cit. (nota 126 supra), pp. 213-214. O autor cita como exemplo dos direitos genéricos dos associados: a sociedade deve ser constituída no interesse comum dos associados; de forma alguma as obrigações dos associados podem ser aumentadas sem o consentimento deles; todos os associados possuem o direito de participar das decisões coletivas; os direitos de cada associado em relação ao capital são proporcionais à sua contribuição.

${ }^{683}$ Cf. Y. GuYON, Les Sociétés cit. (nota 126 supra), pp. 213-214.
} 
IV.9. Direito de retirada dos associados

O Código Civil estabelece, no seu artigo 54 inciso II, que o estatuto deve estabelecer os requisitos para a admissão, demissão e exclusão dos associados ${ }^{684}$.

Contudo, nada foi previsto acerca das condições do direito de retirada, cabendo analisar se é de fato um direito do membro que não pode ser excluído, sob pena de violação ao princípio constitucional de liberdade de associação, ou se é permitida a sua supressão, em casos específicos. Pretendemos, também, tratar dos efeitos da retirada voluntária dos associados.

Os membros das associações possuem direito à egressão, ou seja, de se retirar da pessoa jurídica, podendo o estatuto estabelecer exceções à retirada ${ }^{685}$.

A retirada de um membro pode ocorrer com o recesso, que será tratado no presente item, ou com a exclusão, abordada no próximo item.

Para M. BASILE, o direito de recesso da relação associativa é garantido através da aplicação de um princípio de liberdade individual que possui fundamento constitucional. Trata-se de exercício de um direito individual dos membros de se retirar do grupo. A garantia se opera em relação aos vínculos atuais e aos derivados da ação futura do grupo, mas não nos casos em que a participação ao ente seja automática ou obrigatória ${ }^{686}$.

\footnotetext{
${ }^{684}$ Ver F. AMARAL, Direito Civil cit. (nota 27 supra), p. 290: “O estatuto fixa também os requisitos para a admissão, demissão e exclusão de associados, isto é, o surgimento, modificação e extinção da relação associativa. $\mathrm{O}$ associado é titular de uma situação jurídica complexa que nasce do próprio ato constitutivo ou, se a associação é já existente, do negócio jurídico de admissão, isto é, da adesão do interessado aceita pela entidade. A admissão pressupõe o cumprimento de determinados requisitos pelo interessado, que se obriga ao cumprimento das disposições estatutárias. Do mesmo modo que o associado tem o poder de associar-se, no exercício da liberdade constitucional de associação para fins lícitos, tem também o direito de retirar-se, desfazendo unilateralmente a relação associativa, o que faz por meio de sua demissão, ato voluntário pelo qual se retira da associação. Nenhum associado pode ser impedido de exercer esse direito, assim como qualquer função que lhe tenha sido legitimamente deferida (Código Civil, art. 58). Pode, todavia a associação condicionar a aprovação do pedido de demissão ao cumprimento dos deveres estatutários até aquele momento."

${ }^{685}$ Ver F. C. PONTES DE MIRANDA, Tratado de Direito Privado cit. (nota 4 supra), p. 402 . Qualquer membro pode se retirar da associação, produzindo determinados efeitos: "Com a retirada, extinguem-se os direitos organizativos". A retirada pode se dar por renúncia, que "é declaração unilateral de vontade, dirigida ao órgão que o ato constitutivo haja indicado". Sobre as restrições que podem ser colocadas à renúncia, esclarece o autor: "As restrições temporais que podem ser feitas à renúncia são a do ano financeiro, ou social, e o prazo de denúncia, dito, vulgarmente, prazo de aviso prévio. As outras restrições são ilícitas, porque ofenderiam o princípio da egressibilidade. Também é ilícita a restrição de só se poder renunciar havendo razão para isso: seria transformar a renúncia em exercício do direito formativo extintivo, que emanaria do fato em que consiste a razão. (...) Toda eficácia da renúncia é ex nunc."

${ }^{686}$ Le persone giuridiche cit. (nota 54 supra), p. 121.
} 
Os limites a esse direitos são muito restritos, sendo justificáveis somente quando não afrontarem o princípio de liberdade das associações. No direito italiano podem existir, por exemplo, normas que obriguem o membro a participar do grupo por um tempo determinado e sobre a postergação da eficácia do recesso para o final do ano em curso, desde que a declaração tenha sido feita até três meses antes. Por isso, a jurisprudência tem admitido o recesso por justa causa das entidades com prazo indeterminado ou longo. A norma que impõe a forma escrita da comunicação de retirada aos administradores não é um limite, e sim apenas uma modalidade do exercício do direito de recesso ${ }^{687}$.

M. BESSONE defende que os associados possuem o direito de recesso da entidade, o que deriva do seu caráter consensual. A norma legal sobre tal matéria é derrogável pelo estatuto. O recesso parece ser permitido nas associações não reconhecidas a prazo indeterminado, quando houver previsão no estatuto ou no ato constitutivo com determinados motivos, como uma modificação deles não aprovada pelo associado e sempre que houver justa causa. As cláusulas que o excluírem ou tornarem muito oneroso serão nulas $^{688}$.

Para F. GALGANO, o associado possui o direito de retirada a não ser que tenha se obrigado a participar da associação por um prazo determinado. A declaração de recesso deve ser comunicada por escrito aos administradores e tem efeito com o transcurso do ano em curso, desde que seja feita com pelo menos três meses de antecedência. Os membros que se retirarem não terão direito a reaver as contribuições efetuadas ou sobre o patrimônio da associação ${ }^{689}$.

E. C. R. Gorga explica que o direito de recesso nas sociedades anônimas é uma proteção aos acionistas minoritários, nas hipóteses de ocorrência de mudanças substanciais na companhia, das quais dissentirem. O acionista que não concordar com essas alterações poderá se retirar, devendo as suas ações serem adquiridas pela sociedade, por um preço adequado ${ }^{690}$.

Assim, os dissidentes de determinada deliberação gozarão do direito de reembolso do valor de suas ações, como uma compensação por se sentirem prejudicados

\footnotetext{
${ }^{687}$ Ver M. BASILE, Le persone giuridiche cit. (nota 54 supra), pp. 121-122.

${ }^{688}$ Casi e questioni cit. (nota 254 supra), pp.69-70.

${ }^{689}$ Persone giuridiche cit. (nota 57 supra), pp. 361-365.

${ }^{690}$ Direito Societário Brasileiro e Desenvolvimento do Mercado de Capitais: Uma Perspectiva de Direito e Economia, Tese (doutorado) - Faculdade de Direito da USP, São Paulo, 2005, p. 261.
} 
por uma negociação que possa alterar o risco que pretendiam assumir quando adquiriram participação na companhia $^{691}$.

Nas associações o membro poderá se retirar se discordar de uma deliberação tomada, pois não pode ser obrigado a permanecer numa entidade diversa da qual havia aderido. Por outro lado, não receberá reembolso pelas suas quotas, não havendo em tais entidades a mesma função econômica característica do recesso nas sociedades anônimas.

O direito de recesso ao associado é reconhecido como uma derrogação ao princípio geral segundo o qual "o contrato só pode ser dissolvido por mútuo consenso". As partes podem, com a própria declaração unilateral de vontade, provocar a dissolução do vínculo que as unem às outras. Essa derrogação se justifica para tutelar a liberdade individual, um aspecto da liberdade de associação. Será nula a cláusula que excluir o direito de recesso dos membros. Além de limites de validade, o pacto de não se retirar por determinado prazo encontra limites de eficácia. O associado, apesar do pactuado, pode se retirar da entidade tantas vezes quanto surgirem justas causas para o recesso, pois não pode ficar vinculado a um ente diferente daquele a que havia aderido ${ }^{692}$.

A declaração de recesso não possui efeito imediato e não pode ser revogada. Se o associado não quiser mais sair, deverá fazer uma nova adesão à entidade. O estatuto poderá, contudo, derrogar tal disposição e atribuir eficácia imediata ao recesso. Contudo, quando se trata de hipótese por justa causa, deve ser atribuído efeito imediato, pois apenas o imotivado não tem essa eficácia ${ }^{693}$.

O artigo $4^{\circ}$ da Lei francesa de $1^{\circ}$ de julho de 1901 estabelece que todos os membros de uma associação que não for constituída por prazo determinado podem se retirar a qualquer momento, depois de pagar as contribuições e a anuidade corrente, inobstante cláusulas em contrário.

As liberdades de adesão e demissão são protegidas. Aplica-se o princípio geral de direito civil em virtude do qual em todo contrato por tempo indeterminado, uma das partes contratantes pode resilir unilateralmente, a qualquer tempo, a relação jurídica em que figura. As cláusulas suprimindo esse direito serão nulas. O associado pode se retirar

\footnotetext{
${ }^{691}$ E.C. R. GorgA, Direito Societário Brasileiro cit. (nota 690 supra), p. 262.

${ }^{692}$ Persone giuridiche cit. (nota 57 supra), pp. 361-365.

${ }^{693}$ Persone giuridiche cit. (nota 57 supra), pp. 365-369.
} 
livremente, sem necessidade de respeitar um pré-aviso. Contudo, a demissão abusiva que causar danos à entidade pode gerar um direito à reparação ${ }^{694}$.

Quando a duração for por prazo determinado, cabe distinguir duas situações: a existência no estatuto da associação do direito de demissão e a ausência de qualquer disposição nesse sentido. No primeiro caso, as partes do contrato associativo aceitaram, por antecipação, as eventuais demissões de seus membros. Se nada foi previsto, aplicam-se os princípios gerais do direito dos contratos, podendo o associado se retirar somente se a sua demissão for aceita pelos outros membros ou pelo órgão de administração. Em caso de recusa, o retirante deve se dirigir ao poder judiciário para obter a resolução do contrato de associação em relação a ele ${ }^{695}$.

A doutrina francesa explica, acerca das vantagens do recesso, que ele permite a um associado redimir os seus direitos sociais a qualquer momento pelos outros membros ou pela entidade. Pode deixar o ente sem a necessidade de encontrar um adquirente. Os estatutos devem fixar as condições de exercício do recesso, prevendo se ele será discricionário ou motivado, se o membro deve dar um aviso prévio e de quanto tempo e como esses direitos serão repartidos entre os associados que permanecerem na entidade $^{696}$.

Deve ser evitada a faculdade de recesso discricionária, para pelo menos garantir um recurso à justiça em caso de abuso ${ }^{697}$.

A retirada da associação pressupõe o término dos direitos e obrigações integrados na condição de membro.

A jurisprudência brasileira tem admitido que o associado poderá se retirar livremente do ente, em razão do preceito constitucional de liberdade de associação, que impede que uma pessoa seja compelida a se associar ou a permanecer associada. Poderá fazê-lo mediante simples envio de carta registrada contendo a manifestação de vontade de exclusão do quadro social. Contudo, não poderá impedir os demais membros de darem continuidade à associação, que, por não possuir fins lucrativos, não admite a sua dissolução parcial, com apuração de haveres ${ }^{698}$.

\footnotetext{
${ }^{694}$ Ver S. DAMAREY et al, Code cit. (nota 34 supra), p. 39.

${ }^{695}$ S. DAMAREY et al, Code cit. (nota 34 supra), pp. 39-40.

${ }^{696}$ Cf. Y. GuYON, Les Sociétés cit. (nota 126 supra), p. 88.

${ }^{697}$ Cf. Y. GuYON, Les Sociétés cit. (nota 126 supra), p. 90.

${ }^{698}$ TJSP, $1{ }^{\text {a }}$ Câm. de Dir. Priv., Apel. Cível n. 99406122884-8, rel. Paulo Eduardo Razuk, j. 30-11-2010.
} 
Os associados que não usufruíram dos serviços prestados pela associação poderão exercer o direito de retirada com base no artigo $5^{\circ} \mathrm{XX}$ da Constituição Federal que dispõe: "Ninguém poderá ser compelido a associar-se ou a permanecer associado." 699

IV.10. Exclusão dos membros. A justa causa. Procedimento e defesa do associado. Efeitos da exclusão

O artigo 54 do Código Civil brasileiro estabelece que o estatuto das associações deverá conter, sob pena de nulidade, os requisitos para a exclusão dos associados.

Ela só será admissível, segundo o artigo 57 do Código Civil, havendo justa causa, assim reconhecida em procedimento que assegure o direito de defesa e de recurso, nos termos previstos no estatuto.

Verificamos, portanto, que existe autonomia para os associados disciplinarem, no estatuto, as suas causas de exclusão. Contudo, fica condicionada à existência de justa causa, devendo ser assegurado ao membro a ser excluído o direito de defesa e de apresentação de recurso, procedimento que também deve ser previsto no estatuto.

F. U. COELHO explica que existem diversas sanções previstas no estatuto para o descumprimento de deveres previstos, desde a simples advertência, à suspensão temporária, até a exclusão ${ }^{700}$.

Faz-se necessário, portanto, definir o que se entende por justa causa para a exclusão, sanção máxima para descumprimento dos deveres estatutários, bem como estipular as suas possíveis causas e o procedimento a ser seguido.

A exclusão representa um ato desempenhado no exercício da função disciplinar confiada aos órgãos da associação.

De acordo com M. BASILE uma parte relevante da atividade dos entes de caráter associativo assume uma função disciplinar, ou seja, o poder de aplicar aos membros que tenham lesado um interesse coletivo punições ou penas, como a exclusão do grupo, a

\footnotetext{
${ }^{699}$ TJSP, $3^{\text {a }}$ Câm. de Dir. Priv., Apel. Cível n. 0013012-69.2009.8.26.0292, rel. Donegá Morandini, s.d.

${ }^{700}$ Curso de Direito Civil cit. (nota 10 supra), p. 252.
} 
perda de um direito, o pagamento de uma soma de dinheiro e outras medidas análogas. A exclusão do associado pode ser caracterizada como uma pena privada, fundamentando-se as medidas sancionatórias na autonomia coletiva ${ }^{701}$.

Contudo, o autor adverte que não podemos equiparar o poder de inserir cláusulas disciplinares nos estatutos das associações às cláusulas penais dos contratos, pois as medidas disciplinares associativas podem ter valor moral ou social, mais do que econômico $^{702}$.

Além do descumprimento dos deveres estatutários, a quebra do affectio societatis, elemento essencial a qualquer associação ou sociedade, de acordo com C. R. GONÇALVES, pode constituir justa causa para a exclusão do associado. A "justa causa", contudo, exige demonstração fática e decisão fundamentada, tomada pela maioria, conforme o quorum estabelecido no estatuto, com respeito ao contraditório e à ampla $\operatorname{defesa}^{703}$.

A indicação no estatuto das causas de exclusão pode ser exemplificativa ou taxativa. Dentre os motivos graves M. H. DINIZ elenca: locupletamento ilícito, conduta imoral, atitude preconceituosa contra outro associado, ato atentatório aos interesses da entidade e outros $^{704}$.

$\mathrm{Na}$ omissão do estatuto a exclusão poderá ocorrer havendo motivo entendido como grave, contrário aos interesses da associação, desde que seja respeitado o exercício do direito de defesa do membro que se pretenda excluir. Havendo previsão estatutária, o associado excluído pode interpor recurso à assembleia geral, ou ainda questionar judicialmente o seu direito de permanecer na entidade ${ }^{705}$.

Contudo, lembramos que o estatuto deve conter os requisitos para exclusão dos associados, não podendo ser omisso, sob pena de nulidade. Pode ser previsto, contudo, rol exemplificativo de causas de exclusão, sendo admissíveis outras, consideráveis como graves e contrárias aos interesses da entidade, desde que seja seguido o procedimento para exclusão, respeitando o direito de defesa do associado.

\footnotetext{
${ }^{701}$ Le Persone giuridiche cit. (nota 54 supra), pp. 258-259.

${ }^{702}$ Le Persone giuridiche cit. (nota 54 supra), pp. 262-263.

${ }^{703}$ Direito Civil Brasileiro cit. (nota 80 supra), p. 202.

${ }^{704}$ Curso de Direito Civil cit. (nota 13 supra), pp. 255- 256.

${ }^{705}$ Cf. M. H. DINIZ, Curso de Direito Civil cit. (nota 13 supra), pp. 255- 256.
} 
Para G. Moreno Talavera os critérios de exclusão dos associados devem ser objetivos, sob pena de violação do princípio da isonomia e potencial discriminação e preconceito do membro a ser retirado da entidade. ${ }^{706}$.

O estatuto, ao invés de enumerar as possíveis causas de exclusão, pode conter ainda normas programáticas, dando diretrizes que deverão ser realizadas por algum órgão do ente ${ }^{707}$.

A deliberação que determinar a exclusão do associado poderá ser anulada se ocorrer de forma unilateral, sem permitir ao excluído o exercício do seu direito de defesa, ou seja, se for efetuada em desacordo ao procedimento previsto no estatuto ${ }^{708}$.

O artigo 24 do Código Civil italiano estabelece que compete à assembleia deliberar sobre a exclusão de um associado, que deve ser fundamentada em motivos graves. O membro possui o prazo prescricional de seis meses, contados da notificação sobre a deliberação de exclusão, para impugná-la judicialmente. Os associados excluídos não podem ser reembolsados das suas contribuições e não possuem nenhum direito sobre o patrimônio das entidades.

De acordo com M. BESSONE o artigo acima citado, ao estabelecer que a exclusão de um associado pode ser deliberada pela assembleia, não precisa se é derrogável a regra que reserva a este órgão o pronunciamento acerca de tal procedimento. A maioria da doutrina entende, contudo, que a regra é derrogável, podendo o ato constitutivo ou o estatuto indicarem outros órgãos da associação como competentes a deliberar nesse sentido. A maioria da jurisprudência, por outro lado, é contrária, não aceitando a derrogação no caso das entidades reconhecidas, mas permitindo para as não reconhecidas $^{709}$.

Os motivos graves para a exclusão ou, como preferiu o legislador brasileiro, a justa causa, podem ser exemplificados no ato constitutivo e estatuto, incluindo-se, ainda, as hipóteses que possam gerar danos à associação. Eles contêm, normalmente, rol exemplificativo dos casos de exclusão dos associados. Os motivos graves ou a justa causa

\footnotetext{
${ }^{706}$ Das Associações cit. (nota 348 supra), p. 211.

${ }^{707}$ Ver F. C. PONTES DE MIRANDA, Tratado de Direito Privado cit. (nota 4 supra), p. 398.

${ }^{708}$ Tratado de Direito Privado cit. (nota 4 supra), p. 398.

${ }^{709}$ Casi e questioni cit. (nota 254 supra), p. 392.
} 
que fundamentam a deliberação devem ser levados ao conhecimento do membro a ser excluído, de forma a se permitir a sua contestação e defesa adequadas ${ }^{710}$.

Para M. BASILE a exclusão de um associado só pode ser deliberada pela assembleia em presença de motivos graves, podendo haver delegação dessa função ao conselho de administração ou a outros órgãos dotados de poderes disciplinares. $\mathrm{O}$ autor adverte que a deliberação de exclusão não pode ser comparada a uma cláusula resolutiva de um contrato, pois o poder de exclusão não se baseia nos princípios de resolução dos contratos por inadimplemento ou de impossibilidade superveniente da prestação. Os motivos graves compreendem, na verdade, atos diversos do inadimplemento de obrigações e eventos que tornem impossível ao membro a sua observância ${ }^{711}$.

No mesmo sentido, F. GALGANO ressalta que a exclusão do associado está subordinada à ocorrência de uma justa causa, não sendo possível a deliberação injustificada e arbitrária. O artigo 24 do Código Civil italiano reconhece a cada membro o direito de permanecer na entidade, ou na relação contratual, sendo tal direito suprimido apenas na presença de justa causa. O legislador italiano não elencou as hipóteses de justa causa para exclusão das associações, e nem há exigência que o ato constitutivo as contenha, como existe no direito brasileiro. A análise da configuração do motivo grave caberá ao juiz, em cada caso concreto, podendo, todavia, o estatuto prevê-los ${ }^{712}$.

Esta análise pode ser feita aplicando-se os princípios gerais dos contratos e levando em consideração que hipóteses justificariam a resolução da relação contratual plurilateral e, em especial, o inadimplemento do associado, ou os eventos que tenham tornado impossível o cumprimento da prestação, valendo como inadimplemento qualquer violação que possa ser considerada grave das obrigações impostas aos associados pelo estatuto, e não apenas a ausência de prestação das contribuições ${ }^{713}$.

A justa causa para a exclusão corresponde à gravidade do inadimplemento das obrigações que derivam da lei ou do contrato social, previsto nas sociedades de pessoas. O inadimplemento e a impossibilidade superveniente podem se referir ainda a outra obrigação genérica do associado: o dever de colaboração, inerente ao conteúdo legal do contrato associativo. Existem, portanto, causas de exclusão que não possuem relação

\footnotetext{
${ }^{710}$ Cf. M. BESSONe, Casi e questioni cit. (nota 254 supra), pp. 392-393.

${ }^{711}$ Le Persone giuridiche cit. (nota 54 supra), pp. 259-260.

${ }^{712}$ Persone giuridiche cit. (nota 57 supra), pp. 370-372.

${ }^{713}$ Ver F. GALGANO, Persone giuridiche cit. (nota 57 supra), pp. 370-372.
} 
com as causas de resolução do contrato em geral e a exclusão do associado é uma figura irreconduzível ao esquema de resolução do contrato plurilateral $^{714}$.

A justa causa também pode se configurar quando o associado perder os requisitos de admissão previstos no ato constitutivo para ingresso na entidade. Nesse sentido, perderá o direito de permanência no ente. Na teoria dos contratos, seria equivalente a uma causa superveniente, ou seja, uma hipótese de modificação, sucessiva à formação, da base real do contrato. A permanência na associação pode ser, ainda, condicionada à posse de determinados requisitos subjetivos, da série ou categoria enunciada pelo ato constitutivo. Se o membro perder esses requisitos, configura-se uma justa causa para exclusão e também para o direito de recesso. Poderá também ser deliberada a exclusão por indignidade moral do associado ${ }^{715}$.

A norma que prevê a necessidade de deliberação por parte da assembleia não é inderrogável e o estatuto pode, portanto, prever outro procedimento, atribuindo a deliberação aos administradores ou a outros órgãos. A referida deliberação produz efeito no momento da notificação ao associado excluído. Apesar de não haver menção no artigo 24 do Código Civil italiano, deve-se entender admissível a exclusão de direito, ou seja, o ato constitutivo pode prever hipóteses de justa causa que, caso verificadas, produzem o efeito imediato de exclusão do associado da entidade, independente da tomada de uma deliberação específica. A hipótese não corresponde àquela da cláusula resolutiva expressa, pois é prevista, para a assembleia, a faculdade de não se utilizar da cláusula. Deve haver necessariamente uma declaração formal do órgão administrativo de exclusão do associado, com a sua posterior notificação ${ }^{716}$.

A deliberação de exclusão deve ser motivada, podendo o associado excluído questionar a sua regularidade formal. Poderá também discutir o mérito, em especial a existência dos graves motivos necessários. O juiz não deve analisar o mérito da exclusão propriamente, e sim verificar se não houve abusos por parte da maioria, no sentido de exercer o poder fora da forma prevista em lei e no estatuto. Deverá analisar se o associado praticou o ato a ele imputado e isso se enquadra dentre os graves motivos para proceder à exclusão. Fato grave é aquele apto a prejudicar a realização dos escopos previstos pela

\footnotetext{
${ }^{714}$ Ver F. Galgano, Persone giuridiche cit. (nota 57 supra), pp. 370-372.

${ }^{715}$ Ver F. Galgano, Persone giuridiche cit. (nota 57 supra), pp. 373-377.

${ }^{716}$ Ver F. GALGAnO, Persone giuridiche cit. (nota 57 supra), pp. 378-380.
} 
associação. $\mathrm{O}$ ato constitutivo não pode subtrair ao membro a possibilidade de recorrer ao judiciário $^{717}$.

A doutrina francesa considera que o sócio ou associado possui o direito de permanecer na sociedade ou associação, direito que possui fundamento contratual. $\mathrm{O}$ membro possui o direito de não ser excluído da entidade, caracterizando-se a exclusão como uma resolução do contrato que liga o associado ao ente, lembrando que a resolução supõe uma culpa. A exclusão é possível a título de sanção ou punição do associado ou ainda como regularização, quando ele for excluído para permitir a sobrevivência da entidade ou mesmo o seu regular funcionamento. Essas causas, contudo, são difíceis de se justificar com o direito das obrigações, parecendo se referir a uma aplicação do affectio societatis, pois o interesse particular do membro é sacrificado em prol dos objetivos do ente $^{718}$

No direito alemão as formas básicas de sanção aos sócios e associados são a repreensão, a multa e a mais grave delas é a exclusão. Para que ocorra é necessário um motivo estabelecido nos estatutos ou, na omissão deste, uma justa causa ${ }^{719}$.

A doutrina alemã explica que o controle judicial das hipóteses de exclusão é importante nos casos em que o equilíbrio entre a organização e o indivíduo tenha se alterado em prejuízo dos associados, em razão de modificações na estrutura e nas funções das associações modernas. A jurisprudência tem entendido que o judiciário pode revisar se as medidas disciplinares das entidades foram equitativas no caso concreto com cautela, estabelecendo que só são passíveis de correção as decisões ilícitas, imorais ou claramente inequitativas, o que tem sofrido críticas por parte da doutrina ${ }^{720}$.

F. KÜBLER concorda com a orientação jurisprudencial, deduzindo que os estatutos não podem excluir a possibilidade de se exigir a revisão judicial das medidas disciplinarias da associação, sendo eventual cláusula nesse sentido nula. Além disso, o associado somente pode se dirigir à instância judicial quando houver esgotado as instâncias internas previstas no estatuto. Deve ser sempre garantido a ele o direito de defesa, e a revisão judicial deve se limitar a verificar se a sanção está de acordo com os estatutos, se

\footnotetext{
${ }^{717}$ Ver F. GALGANO, Persone giuridiche cit. (nota 57 supra), pp. 380-384.

${ }^{718}$ Cf. Y. GuYON, Les Sociétés cit. (nota 126 supra), pp. 79-81.

${ }^{719}$ Ver F. KÜBLER, Derecho de Sociedades cit. (nota 61 supra), p. 222.

${ }^{720}$ Ver F. KÜBLER, Derecho de Sociedades cit. (nota 61 supra), p. 704.
} 
observou o procedimento estabelecido, se as disposições estatutárias não são contrárias à lei ou à moral ou se a sanção não é claramente injusta ${ }^{721}$.

Inicialmente não se podia examinar os pressupostos de fato, mas agora isso tem sido admitido. As associações são livres, a princípio, para regular em seus estatutos as relações internas, mas aquelas com posição dominante ou situação de monopólio devem aceitar uma certa limitação a esta autonomia ${ }^{722}$.

A exclusão pode ser aplicada se houver justa causa mesmo na omissão do estatuto, pode ser facilitada em virtude das normas estatutárias ou de acordos pelo órgão competente e a competência para tomar a deliberação pode ser outorgada à diretoria ${ }^{723}$.

F. C. PONTES DE MIRANDA explica que os efeitos da exclusão são a extinção dos direitos específicos gerais e preferentes dos associados ${ }^{724}$.

Em relação às penalidades que podem ser aplicadas aos associados, iniciando pela suspensão, a jurisprudência brasileira entende que se trata de exercício regular do direito da associação aplicar pena de suspensão ao associado, desde que o faça respeitando o devido processo legal e a ampla defesa. A instauração do processo disciplinar e a aplicação da punição, efetuadas de acordo com o estatuto da entidade, não geram direito à indenização por danos morais ${ }^{725}$.

A penalidade máxima aplicável ao associado é a exclusão da entidade. Sobre ela, a jurisprudência é ampla. Existe um importante precedente do STF que aplicou à exclusão dos associados os princípios constitucionais do contraditório e da ampla defesa, atribuindo eficácia a esses direitos fundamentais nas relações privadas. Nesse sentido, decidiu-se que o espaço de autonomia privada garantido pela Constituição Federal às associações não está imune à incidência dos princípios constitucionais que asseguram o respeito aos direitos fundamentais de seus membros, inclusive no tocante à exclusão ${ }^{726}$.

Os tribunais têm julgado os casos de exclusão dos associados em consonância com esse precedente. ${ }^{727} 728$ A instauração de procedimento administrativo é

\footnotetext{
${ }^{721}$ Derecho de Sociedades cit. (nota 61 supra), pp. 704-705.

${ }^{722}$ Ver F. KüBLER, Derecho de Sociedades cit. (nota 61 supra), pp. 704-705.

${ }^{723}$ Ver F. KÜBLER, Derecho de Sociedades cit. (nota 61 supra), p. 706.

${ }^{724}$ Tratado de Direito Privado cit. (nota 4 supra), p. 403.

${ }^{725}$ TJMG, $12^{\mathrm{a}}$ Câm. Cível, Apel. Cível n. 1071308080233-1/001(1), rel. Alvimar de Ávila, j. 19-8-2009.

${ }_{726}^{72}$ STF, $2^{\text {a }}$ Turma, R. Ext. n. 201.819-8, rel. Gilmar Mendes, j. 11-10-2005.

${ }^{727}$ O STF assentou a possibilidade de aplicação dos direitos fundamentais assegurados pela CF para a proteção dos particulares contra os poderes privados. Os direitos fundamentais podem limitar a autonomia privada de uma associação. (RE 160.222-8, RE 158215-4, RE 161243-6, RE 175161-4, RE 201819).
} 
exercício regular de um direito da associação. Contudo, o pedido de exclusão do membro deve ser procedido do devido processo legal, com respeito às previsões estatutárias da associação, sob pena de anulação da penalidade. Cabe ao Judiciário examinar a legalidade do ato, e nunca os critérios de conveniência e oportunidade da entidade associativa ${ }^{729}$.

Agindo a entidade no exercício regular de um direito, ao intentar procedimento administrativo contra o associado, que acabou excluído, não há nenhuma ilicitude capaz de ensejar dano moral nesse procedimento adotado ${ }^{730}$.

A exclusão do associado não pode se dar sem a observância dos princípios da ampla defesa e do contraditório e sem justa causa. Não poderá correr a guisa dos direitos fundamentais, sob pena de violação da CF. É cabível o ressarcimento por danos materiais, como taxa de adesão. Já o ressarcimento por danos morais só tem cabimento se acompanhado de circunstâncias especiais que caracterizem a ofensa a direitos da personalidade $^{731732}$.

Além da necessidade de o procedimento de expulsão respeitar os princípios constitucionais mencionados, deve haver uma justa causa. A exclusão de associado só pode ser concretizada, portanto, se houver motivo grave e desde que seja a ele garantido o direito ao contraditório e a ampla defesa ${ }^{733} 734$.

\footnotetext{
${ }^{728}$ No mesmo sentido, aplicando o precedente do STF: "Na hipótese de exclusão de associado decorrente de conduta contrária ao estatuto, impõe-se a observância ao devido processo legal, viabilizando o exercício

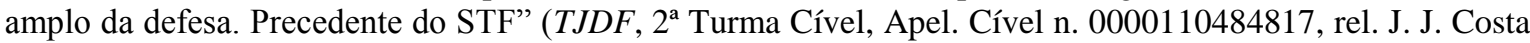
Carvalho, j. 13.12.2004) e "Impossibilidade de exclusão do associado por ato da diretoria sem a garantia do devido processo legal, dos princípios da ampla defesa e do contraditório" (TJSP, $1^{\mathrm{a}}$ Câm. Dir.Priv., Apel. Cível n. 99406017234-2, rel. Paulo Eduardo Razuk, j. 30-11-2010) e "Exclusão de associado. Necessidade de notificação para que o associado inadimplente pagasse os atrasados ou se defendesse administrativamente. Aplicação dos princípios da ampla defesa e do contraditório às associações civis, conforme jurisprudência do STF". (TJRS, $1^{\text {a }}$ Turma Rec. Cível dos Juizados Esp. Cíveis, Recurso inominado n. 71003131679, rel. Leandro Raul Klippel, j. 7-6-11).

${ }^{729}$ TJMG, $18^{\text {a }}$ Câm. Cível, Apel. Cível n. 1014503110231-5-001, rel. Guilherme Luciano Baeta Nunes, j. 301-2007.

${ }^{730}$ TJMG, 14a Câm. Cível, Apel. Cível n. 1068706042407-8-001, rel. Rogério Medeiros, j. 28-8-2008.

${ }^{731}$ TJMG, 13ª Câm. Cível, Apel. Cível n. 1033807059846-5-001, rel. Cláudia Lima, j. 21-5-2009.

${ }^{732}$ No mesmo sentido: "A exclusão de associado não pode se dar em desrespeito ao devido processo legal. Constatada a nulidade do procedimento de exclusão por cerceamento de defesa, deve ser reintegrada a parte. Apesar de ser nula, mas havendo fundamento para a exclusão, inexiste dano moral. (TJMG, $14^{\mathrm{a}}$ Câm. Cível, Apel. Cível n. 1070704080504-6-001, rel. Elias Camilo, j. 30-8-2007) e "Expulsão de associados sem a observância do procedimento previsto no regimento interno da associação. Necessidade de prévia notificação. Exclusão indevida que por si só não acarreta dano moral”. (TJSP, $4^{\mathrm{a}}$ Câm. Dir. Priv., Apel. Cível n. 3637014/2-00, rel. Francisco Loureiro, 2-8-2007).

${ }^{733}$ TJSP, 7 a Câm. Dir. Priv., Apel. Cível n. 4482214-0-00, rel. Arthur Del Guercio, j. 23-8-2006.

${ }^{734}$ No mesmo sentido: "Ação pleiteando a declaração de nulidade de exclusão de associados e afastamento do presidente da associação. Presidente havia sido eleito por mandato tampão, até data determinada, tendo havido outro posteriormente eleito. Nulidade da exclusão se eivada de ilegalidade e contrária ao que determina o estatuto da associação, não tendo sido assegurado aos associados o direito de defesa. Inexistência de justa causa para aplicação da penalidade, no caso não restou comprovada a intenção dos associados de
} 
Como dito, o Judiciário não pode apreciar o mérito dos atos administrativos das associações, mas pode apreciar a conformidade desses atos interna corporis com os princípios constitucionais do contraditório e da ampla defesa e com as regras estatutárias da associação ${ }^{735}$. Nesse sentido, a convocação da assembleia para exclusão do membro deverá conter na ordem do dia a deliberação sobre a possível penalidade imputável ao associado e o motivo ${ }^{736}$.

Caso as disposições estatutárias não tenham sido observadas para a exclusão do associado, ele deverá ser reintegrado aos quadros sociais ${ }^{737}$.

R. RoSAS narra que o acolhimento do devido processo legal no direito brasileiro na CF de 88 (art. $5^{\circ}$, LIV) fundamentou a aplicação desse princípio de modo expresso no direito público e no processual. No Direito Privado se aplica o devido processo legal substantivo $^{738}$.

A razoabilidade e proporcionalidade integram o devido processo legal substantivo. O segundo também é conhecido como da proibição do excesso e pode ser entendido como princípio do Estado de Direito, ou direito fundamental ${ }^{739}$.

A solução adotada para a efetivação do ato ou medida deve ser adequada a seu fim. Pode ser invocado no exame do ato discricionário ou do ato vinculado, com a clássica oposição doutrinária de impedimento das razões desses atos. Dentre os elementos integradores da proporcionalidade temos a adequação entre meio e fim do ato (legislativo ou administrativo ou pessoal $)^{740}$.

Sendo assim, a deliberação de exclusão de um associado deve ser adequada e proporcional à retirada do membro faltoso da entidade, proibindo-se os excessos que violem o direito fundamental de associação. Não se trata de análise de mérito do ato, e sim de sua razoabilidade e adequação.

denegrir a imagem ou o nome da associação". (TJRJ, 11 a Câm. Cível, Apel. Cível 007171585.2009.8.19.0001, rel. Otávio Rodrigues, j. 8-6-11).

735 Seguindo essa orientação destacamos o seguinte julgado: "Instituição por assembleia de taxa mínima para associados inativos. Inadimplemento que gerou cancelamento da quota patrimonial. Exclusão do associado, desde que observados os princípios do devido processo legal e ampla defesa. Seguimento do procedimento previsto no estatuto". (TJRJ, $1^{\text {a }}$ Câm. Cível, Apel. Cível 0.307.034-33.2009.8.19.0001, rel. Maldonado de Carvalho, j. 15-2-2011).

${ }^{736}$ TJSP, $2^{\text {a }}$ Câm. Dir. Priv., Apel. Cível n. 173.192-4-8-00, rel. Ariovaldo Santini Teodoro, j. 31-10-2006.

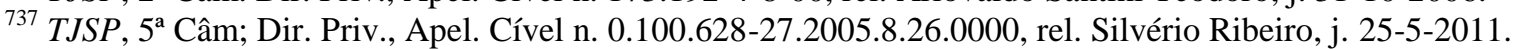

${ }^{738}$ Razoabilidade e Proporcionalidade no Código Civil (2002), in A. Alvim, J. P. de C. César, e R. Rosas (coord.), Aspectos Controvertidos do Novo Código Civil - Estudos em Homenagem ao Ministro José Carlos Moreira Alves, São Paulo, RT, 2003, p. 557.

${ }^{739}$ R. Rosas, Razoabilidade e Proporcionalidade cit. (nota 738 supra), p. 557.

${ }^{740}$ R. RosAS, Razoabilidade e Proporcionalidade cit. (nota 738 supra), p. 558. 
O autor explica que, para melhor adequação da proporcionalidade e da razoabilidade na aplicação do Código Civil, devemos partir de regras constitucionais de direito privado, autêntica eficácia privada dos direitos fundamentais, como o direito à associação. Em consequência, qualquer restrição à liberdade, à pessoa e ao exercício dos direitos sobre bens deve ser proporcional ${ }^{741}$.

As Cortes italianas têm entrado no mérito das disputas entre associados, tomando posições no tocante aos aspectos mais problemáticos da disciplina das relações internas associativas. Há uma inclinação a favor da tutela dos membros, justificada pelas regras de democracia interna feitas pelas próprias associações ou de princípios codificados em vários setores do ordenamento jurídico ${ }^{742}$.

Existem diversos julgados acerca da exclusão dos associados ou do impedimento deles e dos conselheiros de participar de reuniões e assembleias. Notamos, assim como tem feito a jurisprudência brasileira após o julgado do Supremo Tribunal Federal, uma tendência de aplicação dos princípios mínimos para tutela dos direitos individuais dos associados e administradores, como a ampla defesa e o contraditório, reprimindo o abuso de poder, com a utilização, inclusive, da disciplina da responsabilidade civil, para ressarcimento de danos ${ }^{743}$.

\footnotetext{
${ }^{741}$ R. RoSAS, Razoabilidade e Proporcionalidade cit. (nota 738 supra), p. 558.

${ }^{742}$ Ver M. BASILE, Associazioni cit. (nota 214 supra), pp. 214-216. Aplicou-se, nesse sentido, o princípio democrático nas assembleias das associações.

${ }^{743}$ Ver M. BASILE, Associazioni cit. (nota 214 supra), pp. 218-219.
} 


\section{EXTINÇÃO DAS ASSOCIAÇÕES}

Sumário: V.1. Dissolução, liquidação e extinção da associação. V.2. Formas, causas e efeitos da dissolução. V.3. Proibição aos administradores de efetuar novas operações. V.4. Destinação do patrimônio remanescente. Restituição das contribuições aos associados.

V.1. Dissolução, liquidação e extinção da associação

As condições de dissolução da associação e o destino de seu patrimônio devem estar previstos em seu ato constitutivo ou estatuto ${ }^{744}$.

O artigo 51 do Código Civil estabelece que nos casos de dissolução da pessoa jurídica, ou cassada a autorização para o seu funcionamento, ela subsistirá para os fins da liquidação, até que esta se conclua.

A dissolução deve ser averbada no registro onde a pessoa jurídica estiver inscrita. Apenas após o encerramento da liquidação, proceder-se-á ao cancelamento da sua inscrição.

Aplicam-se subsidiariamente às associações as disposições para liquidação de sociedades.

Para tratarmos da extinção das associações devemos, inicialmente, distinguir entre os termos dissolução, liquidação e extinção, que muitas vezes são utilizados de forma equivocada, bem como desde já ressaltar que a personalidade jurídica das associações persiste até o fim da sua liquidação, desaparecendo apenas com a extinção propriamente dita do ente coletivo ${ }^{745} 746$.

\footnotetext{
${ }^{744}$ F. C. PONTES DE MIRANDA, Tratado de Direito Privado cit. (nota 4 supra), critica o emprego do termo "dissolução" para as pessoas jurídicas, explicando que a pessoa jurídica não se dissolve, e sim "deixa de ser, isto é, a entidade que se personificara perde a capacidade de direito." Para o autor: "O que dissolve o suporte fático (...) é o acordo de dissolução, no qual está incluído o ato coletivo extintivo, que é negativa da criação. A dissolução da sociedade sem o ato coletivo para ser levado a registro não pode extinguir a personalidade jurídica, que continua de existir, no plano da existência pessoal, ainda que, no plano obrigacional, se haja extinto o contrato de sociedade."

${ }^{745}$ Segundo F. AMARAL, Direito Civil cit. (nota 27 supra), pp. 291-300: "A associação extingue-se quando realizados ou impossíveis de realização os seus objetivos, e de acordo com as disposições estatutárias". "A dissolução extingue a pessoa jurídica. A entidade, que se personificara, perde a capacidade de direito. A
} 
F. CARDOSO explica que a dissolução é uma fase da extinção, tida como necessária, mas nem sempre suficiente à última, enquanto a extinção é um efeito da dissolução. Durante a dissolução, a pessoa jurídica fica limitada ou diminuída na sua capacidade de agir. Possui, portanto, natureza de fato modificativo e não extintivo. A extinção põe fim à personificação ou à vida da pessoa coletiva. Dissolução é, portanto, a primeira fase de um processo: o processo de extinção ${ }^{747}$.

A extinção da pessoa coletiva é o término da relação jurídica criada pelo ato de constituição, ao passo que a dissolução é tão somente uma alteração ou modificação dessa relação jurídica, preparatória à fase de liquidação e não necessariamente à extinção. As fases do processo de extinção são: dissolução, liquidação e extinção stricto $\operatorname{sensu}^{748}$.

A dissolução é o início ou a primeira fase do processo de extinção da pessoa jurídica, correspondente à verificação de um fato apto a causar o fim do ente coletivo. É um efeito jurídico necessário à extinção, mas não suficiente, como já mencionado. Com a dissolução, a pessoa jurídica não se extingue, embora perdure, praticamente, com esta finalidade. As causas da dissolução são atos ou fatos jurídicos, sendo a dissolução propriamente dita um efeito jurídico dos mesmos, estando tais causas sempre ligadas à perda ou adulteração de um elemento constitutivo da pessoa jurídica, correspondente ao que fora o seu substrato personificável ${ }^{749}$.

A dissolução pressupõe a existência de uma pessoa jurídica validamente constituída, distinguindo-se da anulação ou invalidade, que se verifica quando existe um vício na própria constituição do ente coletivo. Não destrói o ato constitutivo com a sua anulação ou nulidade, e sim apenas o modifica, dando início à liquidação ${ }^{750}$.

\footnotetext{
liquidação refere-se ao patrimônio, significando o pagamento das dívidas e a partilha dos bens. (...) A pessoa jurídica subsiste, para os fins da liquidação, até que esta se conclua."

${ }^{746}$ Cf. L. FrANÇA, Instituições de Direito Civil cit. (nota 49 supra), pp. 76-77, existem cinco espécies de extinção das sociedades ou associações civis: estatutária; convencional; judicial; legal; administrativa. "A extinção estatutária, como o próprio nome está a indicar, é aquela que se opera de acordo com as determinações dos estatutos, como a consecução de determinado fim, o cumprimento de certo prazo ou condição, etc. (...) A extinção convencional é aquela que sem estar necessariamente ligada às disposições estatutárias se verifica em virtude de acordo entre os sócios. (...) A liquidação judicial é aquela que se faz por meio do Poder Judiciário. Pode promovê-la a minoria dos sócios, do mesmo modo que um único sócio ou ainda qualquer pessoa interessada. (...) A extinção legal é aquela oriunda de determinação de lei. (...) Esta espécie de extinção (...) pode operar-se pela simples imposição do preceito legal. Não raro, porém, é necessário que a norma extintora seja complementada por providências de caráter judicial. (...) A extinção administrativa é a que se verifica pela cassação, mediante ato da autoridade competente, da licença para o funcionamento da sociedade. (...)".

${ }^{747}$ Extinção das Pessoas Colectivas cit. (nota 240 supra), pp. 27-34.

${ }^{748}$ Extinção das Pessoas Colectivas cit. (nota 240 supra), p. 49.

${ }^{749}$ Cf. F. CARDOSO, Extinção das Pessoas Colectivas cit. (nota 240 supra), pp. 50-51.

${ }^{750}$ Cf. F. CARDoso, Extinção das Pessoas Colectivas cit. (nota 240 supra), p. 51.
} 
A liquidação é a segunda fase do processo de extinção das pessoas jurídicas, que consiste na terminação dos assuntos em que elas se encontram envolvidas e na apuração final de seus bens, envolvendo a realização do ativo e pagamento do passivo. Elas ainda existem, mas de forma limitada e provisória. No caso das associações o patrimônio é incólume, pois possui uma destinação precisa. A fonte de regulamentação da liquidação pode ser a lei, a vontade do instituidor, ou dos sócios, ou ainda a determinação do poder judiciário. Cabem aos órgãos da associação, mais concretamente à administração, as funções de liquidatário, salvo se os estatutos da entidade definirem outro regime ${ }^{751}$.

A terceira e última fase da extinção das pessoas jurídicas é a sucessão ou destinação dos bens, que acarreta sua extinção propriamente dita. Uma vez dissolvido o ente coletivo, importa saber quem lhe sucede no acervo patrimonial apurado na fase anterior da liquidação. A pessoa jurídica se extingue proprietária de bens, a não ser que a causa da dissolução seja a perda do patrimônio ${ }^{752}$.

O artigo 30 do Código Civil italiano estabelece que, declarada a extinção da pessoa jurídica ou determinada a dissolução da associação, procede-se à liquidação do patrimônio segundo as normas de atuação daquele diploma legal.

No direito italiano, assim como no direito brasileiro, realiza-se a liquidação e a devolução dos bens, para somente ao final obter o cancelamento do ente.

M. BASILE explica que a fase de liquidação determina o destino dos bens que faziam parte do patrimônio e define as relações jurídicas pendentes. Durante toda a sua duração, o ente conserva a sua personalidade jurídica e autonomia patrimonial. $O$ procedimento inicia-se com a nomeação dos liquidantes, que constituirão, após a extinção, o único órgão que regerá a vida da pessoa jurídica, com o objetivo de sistematização das pendências e da liquidação. Os liquidantes podem ser nomeados pela assembleia que deliberou pela dissolução, ou por algum mecanismo, contido no estatuto ou ato constitutivo, ou ainda pela autoridade judiciária, em caso de omissão. Os liquidantes podem ser antigos administradores, variando o número de um a mais, compondo, neste caso, um órgão colegial que deliberará por maioria ${ }^{753}$.

\footnotetext{
${ }^{751}$ Cf. F. CARDoso, Extinção das Pessoas Colectivas cit. (nota 240 supra), pp. 51-53.

${ }^{752}$ Cf. F. CARdoso, Extinção das Pessoas Colectivas cit. (nota 240 supra), pp. 56-59.

${ }^{753}$ Le Persone giuridiche cit. (nota 54 supra), pp. 409-413.
} 
A extinção definitiva só ocorrerá com o término da liquidação. Declarada a extinção da associação ou a sua dissolução, a assembleia deixa de existir. Nas sociedades, cabe à assembleia o poder de revogar os liquidantes; no caso das associações, a competência é da autoridade judiciária ${ }^{754}$.

A dissolução no direito francês também não implica no desaparecimento imediato da personalidade jurídica, que persiste durante o período de liquidação, e evidencia o problema da devolução dos bens do ente coletivo ${ }^{755}$.

A associação no direito brasileiro, bem como em outras legislações, não se extingue imediatamente, passando, portanto, por um processo de liquidação ${ }^{756}$ - para realização do ativo e do passivo - período em que conservará a sua personalidade jurídica até o término da liquidação. ${ }^{757}$

A existência da associação termina, portanto, somente após a conclusão da liquidação, devendo, segundo W. DE BARROS MONTEIRO, a dissolução, ser averbada no registro onde estiver inscrita, para que este, então, seja cancelado ${ }^{758}$.

Para F. C. PonTES DE MIRANDA, por outro lado, pode haver liquidação após o fim da pessoa jurídica ${ }^{759}$.

V.2. Formas, causas e efeitos da dissolução

A Constituição Federal de 1988 já previa regras acerca da dissolução das associações, estabelecendo, em seu artigo $5^{\circ}$, inciso XIX que "as associações só poderão

\footnotetext{
${ }^{754}$ Ver F. Galgano, Persone giuridiche cit. (nota 57 supra), pp. 422-425.

${ }^{755}$ B. TEYssiÉ, Droit Civil cit. (nota 38 supra), pp. 548-549.

${ }^{756}$ Para F. C. PONTES DE MIRANDA, Tratado de Direito Privado cit. (nota 4 supra), p. 437, o que se liquida é o patrimônio, cabendo ao ato constitutivo decidir o seu destino.

${ }^{757}$ Ver M. H. DinIZ, Sociedade e Associação, in CAHALI, Yussef coord., Contratos Nominados, São Paulo, Saraiva, 1995 , p. 375 , acerca dos efeitos da extinção das associações: "Se a associação vier a perder a personalidade jurídica, sua extinção com o cancelamento do registro produzirá efeitos ex nunc, mantendo-se os atos negociais por ela praticados até o instante de seu desaparecimento, respeitando-se direito de terceiros."

${ }^{758}$ Curso de Direito Civil cit. (nota 42 supra), p. 160.

${ }^{759}$ Tratado de Direito Privado cit. (nota 4 supra), p. 431: "Não há princípio a prori, que diga depender da completa liquidação a extinção da personalidade jurídica, porque se pode dar que a lei estabeleça a eficácia ipso iure da causa de extinção. Nem há o princípio a priori da eficácia ipso iure, porque, de regra, exatamente o contrário é que se dá. Portanto, há duas espécies de liquidação, - a liquidação ante-terminação e a liquidação pós-terminação. A pessoa jurídica somente termina ipso iure quando, com o fato, perde a capacidade de direito; e essa tautologia explica que haja liquidações pós-terminação."
} 
ser compulsoriamente dissolvidas ou ter suas atividades suspensas por decisão judicial, exigindo-se, no primeiro caso, o trânsito em julgado".

R. DE RUGGIERO explica que é especial das corporações, como as associações, o modo de extinção que se verifica por falta do elemento pessoal. A entidade poderia, nesse sentido, extinguir-se pela morte ou demissão de todos os seus membros, ou ainda excepcionalmente pela saída de alguns deles ou de apenas um, quando não for admissível a substituição de determinado associado, por guardar vínculo estreitamente pessoal com o ente. Outra forma de extinção seria a dissolução do vínculo, deliberada pela forma estatutária ${ }^{760}$.

A princípio a falta do patrimônio não seria causa para a extinção das associações, como é para as fundações. Contudo, o autor acima citado admite que as associações possam se extinguir com a falta do elemento material, desde que, sem o patrimônio, não possam atingir o seu fim ${ }^{761} 762$.

A associação extingue-se, ainda, quando faltarem os propósitos dos associados, o que pode ser previsto no estatuto; com o fim do prazo determinado no estatuto; pela obtenção do fim perseguido pelos membros ou por impossibilidade de obtêlo ou ilegalidade superveniente, o que normalmente é decidido pelo Estado ${ }^{763}$.

M. BASILE explica que o termo 'dissolução', para as associações, se refere ao seu aspecto contratual, tratando-se de uma hipótese de resolução do acordo. Pode se dar por vontade dos membros ou por outras razões. A associação só se extingue ao termo do procedimento de liquidação, que pode ser dissolução ou extinção ${ }^{764}$.

Para o autor, as associações e fundações se extinguem por causas previstas no ato constitutivo e estatuto, pelo alcance do escopo ou pela impossibilidade superveniente de alcançá-lo. Quanto às associações, é prevista ainda a hipótese de perder todos os seus associados. Contudo, o artigo do Código italiano, que prevê as causas de

\footnotetext{
${ }^{760}$ Instituições de Direito Civil cit. (nota 28 supra), p. 416.

${ }^{761}$ R. DE RuGGIERO, Instituições de Direito Civil cit. (nota 28 supra), p. 417.

762 C. R. Gonçalves, Direito Civil Brasileiro cit. (nota 80 supra), p. 234, discorda da possibilidade de extinção das associações por falta do elemento patrimonial, pois para ele o desaparecimento do capital acarreta a dissolução apenas das sociedades de fins lucrativos, enquanto que as associações, que não possuem finalidade lucrativa, "não se extinguem pelo desaparecimento do capital, que não é requisito de sua existência."

${ }^{763}$ Ver R. DE RugGIERO, Instituições de Direito Civil cit. (nota 28 supra), p. 417: "As mesmas razões que atribuem ao Estado a faculdade de reconhecimento, fazem com que ele o possa retirar às vezes, quando tal seja imposto por motivos de ordem pública ou de interesse geral."

${ }^{764}$ Le Persone giuridiche cit. (nota 54 supra), pp. 376-377.
} 
extinção, não é taxativo, mencionando apenas as hipóteses mais frequentes. Outros casos seriam o término do prazo de vigência e a invalidade do ato constitutivo ${ }^{765}$.

A posição de M. BASILE de incluir os casos de invalidade do ato constitutivo da associação como causa de extinção, difere da posição de F. CARDOSO, narrada no item V.1. acima, que exclui estas hipóteses.

Sendo assim, discordamos do autor no tocante à extinção por invalidade do ato constitutivo, nos casos de nulidade, pois a associação - nesta hipótese - não entra no plano da existência.

No mesmo sentido, destacamos o entendimento de W. MORAES, para quem o termo dissolução, na tradição do direito societário, designa todos os modos, anormais e também normais de extinção de uma sociedade por causa superveniente ao negócio contratual, exceto pela nulidade do contrato ${ }^{766}$.

O quorum, no direito italiano, para tomada da deliberação de dissolução da associação é de três quartos dos membros. O estatuto pode, contudo, aumentar o quorum, inclusive prevendo a necessidade de unanimidade para tanto ${ }^{767}$.

O artigo 27 do Código Civil italiano estabelece que além das causas de extinção previstas no ato constitutivo e no estatuto, a pessoa jurídica se extingue quando o escopo for obtido, ou quando este se tornar impossível. As associações também se extinguem quando faltarem todos os membros. A extinção é declarada pela autoridade governativa, a pedido de qualquer interessado, ou ainda de ofício.

F. GALGAnO, ao comentar o referido artigo, destaca que nele são mencionadas apenas algumas causas de extinção, mas não todas, tratando-se de rol exemplificativo. Existem as causas convencionais de extinção, que operam somente quando previstas no ato constitutivo e estatuto, e as legais, dentre as quais a obtenção do escopo, a impossibilidade superveniente de consegui-lo e, somente no caso das associações, a falta de todos os membros. Outra forma de extinção para as associações é a tomada de deliberação de dissolução, que não se enquadra nas causas convencionais, e opera independente de previsão estatutária. Já o decurso do prazo de duração é causa convencional, enquanto que a declaração de nulidade do contrato de associação é causa

\footnotetext{
${ }^{765}$ Le Persone giuridiche cit. (nota 54 supra), pp. 381-383.

${ }^{766}$ Sociedade Civil Estrita cit. (nota 15 supra), São Paulo, RT, 1987, p. 332.

${ }^{767}$ M. BASILE, Le persone giuridiche cit. (nota 54 supra), p. 384.
} 
legal. A revogação do reconhecimento ou da aquisição da personalidade jurídica pode determinar também, mas não necessariamente, a extinção do ente ${ }^{768}$.

O autor também inclui, portanto, como causa possível de extinção, a declaração de nulidade do contrato de associação.

Já a impossibilidade superveniente da associação obter o seu fim pode ter uma causa interna (como a perda de todo o patrimônio, a impossibilidade de funcionamento ou a contínua inatividade da assembleia) ou externa (alterações na realidade natural ou social e alterações legislativas, que tornem o escopo do ente juridicamente impossível ou ilícito). A duração é uma das possíveis causas convencionais de extinção, mas ela é raramente prevista nos estatutos. Por fim, também pode ser estabelecida uma condição resolutiva, que se entende que opera como causa de extinção ${ }^{769}$.

A verificação de uma dessas causas não importa, por si só, na extinção do ente, que deverá ser declarada pela autoridade governativa, a requerimento de qualquer interessado, ou de ofício. Contudo, há casos em que a declaração faz-se desnecessária, como na ocorrência de dissolução voluntária, deliberada pela assembleia, ou quando a assembleia constatar a ocorrência de uma causa de dissolução, como o decurso do prazo ou a obtenção do escopo ${ }^{770}$.

A fusão e a incorporação não são tidas como causas de extinção da associação, pois o que ocorre nesses casos é uma unificação ou uma integração recíproca dos contratos preexistentes, e não um novo instrumento. ${ }^{771}$.

Parte da doutrina italiana classifica as causas de extinção em convencionais, operantes - somente se previstas no ato constitutivo ou estatuto, ou ainda em deliberações de modificação das cláusulas estatutárias -, e legais, como o alcance do escopo, a impossibilidade superveniente de alcançá-lo e a hipótese de ficar sem associados ${ }^{772}$.

Diversas são as causas de extinção previstas no ato constitutivo de uma associação, podendo se referir à vida inteira do ente, ao elemento subjetivo ou objetivo. As

\footnotetext{
${ }^{768}$ Persone giuridiche cit. (nota 57 supra), pp. 398-399.

${ }^{769}$ F. GAlgano, Persone giuridiche cit. (nota 57 supra), pp. 399-402.

${ }^{770}$ F. Galgano, Persone giuridiche cit. (nota 57 supra), pp. 402-404.

${ }^{771}$ F. GALGANO, Persone giuridiche cit. (nota 57 supra), pp. 404-409.

${ }^{772}$ F. GAlgANO, Persone giuridiche cit. (nota 57 supra), p. 380.
} 
cláusulas que introduzirem hipóteses de dissolução em confronto com normas imperativas, com a ordem pública ou os bons costumes, serão nulas ${ }^{773}$.

O ente pode se extinguir por alcance ou impossibilidade de atingir o escopo, o que constitui uma causa de dissolução comum a todos os contratos associativos, inclusive a sociedade. Para tanto, a impossibilidade deve ser superveniente e ter caráter definitivo e permanente, podendo essa causa operar somente se o fim estiver suficientemente estabelecido, e for realizável num determinado período de tempo. A impossibilidade do escopo abrangeria tanto eventos externos quanto internos à vida do ente ${ }^{774}$.

Outra causa legal é o desaparecimento de todos os membros, por morte, recesso, exclusão ou demissão. A associação, a princípio, pode prosseguir com apenas um associado, podendo ser reconstruída com novos integrantes. O estatuto pode, contudo, prever a necessidade de um número determinado de membros como condição de existência da entidade ${ }^{775}$.

A Lei francesa de 01.07.1901, que dispõe sobre o contrato de associação, estabelece, em seu artigo $9^{\circ}$, que a sua dissolução pode ser voluntária, estatutária ou judicial.

A doutrina francesa menciona, como uma das causas de extinção da associação, a consecução do seu fim. A dissolução voluntária pode ocorrer por vontade dos membros. O estatuto pode prever a dissolução de pleno direito caso um determinado evento se realize, ou fixar um prazo determinado para a duração da entidade. Já os casos de dissolução judicial envolvem objeto ilícito e desrespeito às formalidades ${ }^{776}$.

A dissolução antes do término da duração, denominada antecipada, é normalmente voluntária. A involuntária, por sua vez, se dá por circunstâncias impostas pela lei, como desaparecimento do objeto, morte ou incapacidade de um dos associados; por decisão judiciária, em razão da ocorrência de um vício, falência, liquidação, crime ou delito e por decisão administrativa ${ }^{777}$.

Os estatutos determinam livremente a duração da sociedade, regras que são também aplicáveis às associações, embora possa ser feita uma prorrogação, por decisão

\footnotetext{
${ }^{773}$ F. Galgano, Persone giuridiche cit. (nota 57 supra), p. 382.

${ }^{774}$ F. Galgano, Persone giuridiche cit. (nota 57 supra), pp. 385-388.

${ }^{775}$ F. Galgano, Persone giuridiche cit. (nota 57 supra), pp. 388-390.

${ }^{776}$ P. DELAMARRE, Créer et faire vivre cit. (nota 37 supra), p. 154.

${ }^{777}$ B. TeYssiÉ, Personnes Juridiques cit. (nota 38 supra), pp. 545-547.
} 
tomada pela unanimidade dos associados ou pela maioria, caso haja previsão estatutária. Podem ser fixados outros casos de dissolução, além destes, bem como podem derrogar as causas legais, pois são consideradas por alguns doutrinadores franceses como muito severas $^{778}$.

O Código alemão distingue de forma confusa, de acordo com a doutrina, entre a perda da personalidade jurídica e a dissolução da associação, sem determinar de forma unitária as suas consequências jurídicas ${ }^{779}$.

As causas de dissolução previstas pelo legislador alemão são: deliberação de dissolução pela assembleia dos sócios, por maioria de três quartos, salvo disposição estatutária em contrário; pela chegada do momento ou acontecimento previsto nos estatutos, mas não por consecução ou impossibilidade superveniente do fim social, pois neste caso ele se reduz às tarefas restantes subordinadas a tal fim, em especial a administração do patrimônio da associação; por não remanescer nenhum associado e por proibição administrativa $^{780}$.

Apesar de utilizarem classificações ou nomenclaturas diferentes, os autores brasileiros não divergem em relação às causas de dissolução das associações. Entendem que tais entidades podem se extinguir através da extinção propriamente dita; da dissolução ou da supressão. A primeira delas ocorre quando vem a faltar um dos elementos essenciais da personalidade jurídica. A dissolução é a extinção da pessoa jurídica pela vontade dos associados. Por fim a supressão é a eliminação da personalidade jurídica de uma entidade por ato de autoridade competente ${ }^{781}$.

\footnotetext{
${ }^{778}$ Cf. Yves GuYON, Les Societés cit. (nota 126 supra), pp. 124-126.

${ }^{779}$ Ver F. KÜBLER, Derecho de Sociedades cit. (nota 61 supra), pp. 222-223. Desta forma, a associação pode perder a personalidade jurídica pelas seguintes razões: por não ter reunido os pressupostos para sua inscrição; pela abertura de um procedimento concursal em razão de insolvência ou superendividamento; em virtude de sanção administrativa, motivada pela violação de normas legais ou por exercer uma atividade industrial contrária aos fins estatutariamente estabelecidos; por supressão judicial, por haver redução dos associados a um número inferior a três e por transferência da sede ao exterior.

${ }^{780}$ Ver F. KÜBLER, Derecho de Sociedades cit. (nota 61 supra), p. 223.

${ }^{781}$ Cf. O. GoMes, Introdução ao Direito Civil cit. (nota 51 supra), p. 172: “As associações podem terminar por três modos: a) extinção; b) dissolução; c) supressão. A extinção verifica-se quando vem a faltar um dos elementos essenciais da personalidade jurídica. Deixa, com efeito, de existir, em três hipóteses: a falta da associação, de escopo ou perda de patrimônio. Mesmo que para a extinção seja necessário um ato dissolutório, e, portanto, que jamais se verifique ipso jure, há de provir necessariamente da privação de um dos requisitos essenciais à sua existência. A dissolução é a extinção da pessoa jurídica só pela vontade dos associados, manifestada em ato colegial, de natureza deliberativa, dela própria. A supressão é, finalmente, a eliminação da personalidade jurídica de uma associação por ato da autoridade competente. Distingue-se da extinção e da dissolução porque estas se referem aos elementos intrínsecos da personalidade jurídica, enquanto a supressão entende com o elemento extrínseco, representado pelo registro, o qual deve ser cancelado."
} 
M. H. DINIZ elenca as diversas hipóteses de extinção das associações, dividindo-as em distrato, quando a dissolução for deliberada entre os associados; por determinação legal; por ato governamental, cassando a autorização de seu funcionamento, por não atender às suas finalidades ou por exercer atividades nocivas ao bem público e por dissolução judicial, se a associação for compulsoriamente dissolvida, após o trânsito em julgado da decisão, ou tiver as suas atividades suspensas também por decisão judicial ${ }^{782}$.

C. M. DA Silva PereIRA explica que a dissolução das associações pode se dar de três formas: convencional, legal e administrativa. A convencional é aquela deliberada por declaração de vontade dos membros, devendo obedecer ao quorum previsto no estatuto ou na lei. Já a legal ocorre em razão de um motivo determinado na lei, enquanto a administrativa é a que atinge as pessoas jurídicas que necessitam de aprovação ou de autorização do poder público para se constituir ou para funcionar. Por fim, existe a dissolução judicial, decretada pelo juiz, por iniciativa de qualquer associado, quando se configurar algum dos casos previstos no estatuto ou na lei e a associação continuar funcionando ${ }^{783}$.

A deliberação de dissolução das associações normalmente necessita de um quorum qualificado para a sua tomada, por exemplo, dois terços dos membros, que devem estar reunidos em assembleia especialmente convocada para esse fim. Após a tomada de tal deliberação, será feita a liquidação do ente e, por fim, o cancelamento do registro ${ }^{784}$.

F. C. PONTES DE MiRAnda explica que a deliberação que determinar a dissolução da associação deve ser tomada por maioria absoluta dos associados, calculada excluindo-se as abstenções e as ausências, salvo se o ato constitutivo contiver disposição diversa. $\mathrm{O}$ ato constitutivo pode exigir, inclusive, a realização de duas ou mais assembleias para a tomada de tal deliberação ${ }^{785}$.

Já J. E. S. PAES entende que o quorum para a dissolução da associação pode ser maioria absoluta ou unanimidade, ressaltando que a assembleia deve ser convocada especialmente para este fim $^{786}$.

\footnotetext{
${ }^{782}$ Sociedade e Associação cit. (nota 757 supra), p. 375.

783 Instituições de Direito Civil cit. (nota 22 supra), pp. 235-239.

${ }^{784}$ Cf. F. UlhoA Coelho, Curso de Direito Civil cit. (nota 10 supra), p. 250.

${ }^{785}$ Tratado de Direito Privado cit. (nota 4 supra), p. 431. Para o autor, eventual regra que fizesse indissolúvel a associação não vale, sendo nula, e não anulável.

${ }^{786}$ Fundações, Associações e Entidades cit. (nota 32 supra), p. 181.
} 
A dissolução judicial pode ser pleiteada por provocação ou iniciativa de qualquer associado ou do Ministério Público ${ }^{787}$.

F. CARdoso explica que, em Portugal, o Código de Seabra de 1867 era omisso em relação às causas de dissolução das associações. A doutrina sugeria a aplicação, por analogia, das normas das sociedades comerciais, mas a maior parte dos autores sustentava que as causas de dissolução não poderiam ser as mesmas para todas as pessoas jurídicas, dada a especificidade de cada uma das categorias. Outros entendiam que era necessário analisar previamente quais as condições requeridas para a personificação de cada um dos entes coletivos, sendo que a falta desses requisitos essenciais afetaria, necessariamente, o substrato da pessoa coletiva, impondo-se a dissolução. Às causas de dissolução assim detectadas, acrescentava-se aquelas decorrentes da vontade dos associados. Outras vezes se utilizava da analogia, chegando praticamente às causas hoje estabelecidas no atual Código Civil português ${ }^{788}$.

As associações, por se tratarem de tipo corporativo, podem se extinguir quando desaparece o elemento pessoal. Ele pode determinar as próprias condições de extinção do ente coletivo de que faz parte integrante, quer no ato constitutivo ou no contrato, ou ainda, posteriormente, por deliberação social. Como a associação não possui fins lucrativos, há uma especial atenção do legislador ao elemento teleológico. Quando desaparece o patrimônio dessa entidade, tal fato pode ou não levar à sua extinção, conforme determinação da lei. As causas de dissolução estão direta ou indiretamente ligadas aos elementos constitutivos de fato da pessoa coletiva: pessoal, patrimonial e teleológico $^{789}$.

Para o autor acima citado a enumeração das causas de dissolução das associações é exemplificativa, pois se assim não fosse, a lei não conferiria tão ampla liberdade aos sócios de dissolverem a sociedade, podendo estabelecer causas de dissolução

\footnotetext{
${ }^{787}$ Cf. J. E. S. PAES, Fundações, Associações e Entidades cit. (nota 32 supra), p. 182.

788 Extinção das Pessoas Colectivas cit. (nota 240 supra), pp. 34-36. Eram comuns para associações e fundações as seguintes causas: decurso do prazo; preenchimento do fim; impossibilidade de prosseguir o fim. Específicas para as associações havia a morte, desaparecimento ou renúncia de todos os associados e a vontade expressa dos sócios no sentido da extinção. Outra fonte para a extinção era o Estado ou a entidade competente para o reconhecimento. As causas de dissolução atuais no Código Civil Português comuns às associações, fundações e sociedades civis são: decurso do prazo; preenchimento do fim ou impossibilidade de satisfazê-lo; insolvência; causa extintiva fixada estatutariamente. Já as causas comuns a associações e fundações são: fim diferente do fim expresso; fim sistematicamente prosseguido por meios ilícitos ou imorais; existência contrária à ordem pública. Por fim as causas comuns às associações e sociedades civis são: extinção ou falecimento de todos os associados; deliberação ou acordo dos associados.

${ }^{789}$ Cf. F. CARDOSO, Extinção das Pessoas Colectivas cit. (nota 240 supra), pp. 39-41.
} 
no ato constitutivo e no estatuto, bem como podendo, mais tarde, deliberar por acordo a dissolução da sociedade. A maior parte das causas pode, inclusive, ser afastada por vontade dos particulares. Contudo, para as associações entende ser mais pertinente falar em taxatividade, porque a Constituição portuguesa prevê que elas não poderão ser dissolvidas pelo Estado senão nos casos previstos em lei e mediante decisão judicial, entendimento diverso dos doutrinadores italianos, para os quais as hipóteses são normalmente exemplificativas $^{790}$.

Surgiram na doutrina portuguesa tentativas de tipificação das causas de dissolução. As classificações mais comuns dividiam as causas de dissolução em comuns, aplicáveis a todos os entes coletivos, e específicas; causas legais e voluntárias ou estatutárias, de acordo com a fonte criadora da causa de dissolução; causas normais, já previstas, anormais, determinadas por circunstâncias supervenientes; causas imediatas, formas de dissolução ipso iure, ou seja, que independentemente de qualquer sentença ou deliberação extinguem a pessoa coletiva e mediatas ou facultativas e causas naturais, ocasionadas por eventos naturais, voluntárias, determinadas por vontade dos associados e administrativo-judiciais, determinadas coativamente ${ }^{791}$.

F. CARDOSO, entendendo que as classificações acima são precárias ou ineficazes, propõe a sua classificação, que analisa cada uma das causas de dissolução à luz do interesse que as ditou, obtendo quatro categorias: interesse da comunidade; dos sócios; dos credores e da pessoa jurídica. As primeiras referem-se a um interesse superior ao das partes, como é o caso do fim perseguido por meios ilícitos ou imorais, ou da existência que se torne contrária à ordem pública. As segundas são normalmente estatutárias e dependentes da vontade das partes, como a fusão e cisão, que para os doutrinadores italianos não constituem causas de dissolução. As terceiras são ligadas ao patrimônio das pessoas coletivas, sua perda total ou perturbação, como as hipóteses de falência e insolvência. Por fim, as últimas são hipóteses de dissolução que responsabilizam aqueles que agem em nome do ente coletivo, como a fraude à lei ${ }^{792}$.

A doutrina debate se a eficácia das causas de dissolução operam de pleno direito (causas ope legis), ou se são meros fatos dissolutivos, que carecem, como tal, de supressão administrativa, ou de sentença judicial, ou ainda de deliberação do próprio ente

\footnotetext{
${ }^{790}$ Cf. F. CARDoso, Extinção das Pessoas Colectivas cit. (nota 240 supra), pp. 41-43.

${ }^{791}$ Cf. F. CARdoso, Extinção das Pessoas Colectivas cit. (nota 240 supra), pp. 44-47.

${ }^{792}$ Extinção das Pessoas Colectivas cit. (nota 240 supra), pp. 47-49.
} 
coletivo. Para alguns, a extinção da pessoa jurídica só é possível mediante supressão do Estado, enquanto que para outros, no próprio ato de reconhecimento o Estado estabelece efeito extintivo a certos fatos jurídicos, não sendo necessária nova intervenção. $\mathrm{O}$ autor acima citado sustenta uma solução eclética, entendendo que há fatos ou causas jurídicas a justificar uma intervenção do Estado, bem como há outras causas de "morte natural", sendo importante determinar o momento exato de tal ocorrência para a pessoa jurídica, pois interessa aos associados e também ao público em geral, especialmente àqueles que estabeleceram relações diretas ou indiretas com o ente coletivo ${ }^{793}$.

Em relação às associações, a sua extinção stricto sensu pode resultar da vontade dos associados, da disposição de lei e de decisão judicial. Assim, o momento exato da extinção da entidade parece ser, respectivamente, o da deliberação da assembleia geral, o da ocorrência do ato ou fato juridicamente relevante e o da decisão judicial. A extinção deve ser inscrita no registro nacional das pessoas jurídicas, mas a tal registro não foi atribuído o efeito de supressão da personificação ${ }^{794}$.

F. CARDOSO concluiu que as causas enumeradas em lei para as associações são de dissolução, e não de extinção, e defende que a personalidade jurídica se extingue somente por ocasião da ultimação ou encerramento da liquidação. Contudo, para resguardar a certeza e a segurança do comércio jurídico, o momento da cessação da personalidade jurídica deve ser o do registro do encerramento da liquidação ${ }^{795}$.

A jurisprudência brasileira tem admitido que as associações poderão ser dissolvidas em razão de causas convencionais, legais, administrativas, judiciais ou naturais $^{796}$.

A dissolução poderá ser pleiteada pelo Ministério Público, quando houver, por exemplo, a comprovação de que a pessoa jurídica desvirtuou as suas finalidades, ou quando as atividades exercidas pela entidade forem ilícitas ${ }^{797}$.

Tal pedido de dissolução da associação pelo Ministério Público deve ser analisado a partir de um juízo de equidade sobre a ilegalidade dos fins a que se propõe a entidade $^{798}$.

\footnotetext{
${ }^{793}$ Cf. F. CARDOSO, Extinção das Pessoas Colectivas cit. (nota 240 supra), pp. 63-65.

${ }^{794}$ Cf. F. CARDoso, Extinção das Pessoas Colectivas cit. (nota 240 supra), p. 65.

${ }^{795}$ Extinção das Pessoas Colectivas cit. (nota 240 supra), pp. 72-74.

${ }^{796}$ TJSP, 4 a Câm. Dir. Privado, Apel. Cível n. 994.09.287598-8. rel. Francisco Loureiro, j. 05-08-2010.

${ }^{797}$ TJMG, 2a Câm. Cível, Apel. Cível n. 1.070.207.415.066-6-001, rel. Carreira Machado, j. 11-11-2008 e TJSP, $5^{\text {a } C a ̂ m . ~ D i r . ~ P r i v a d o, ~ A p e l . ~ C i ́ v e l ~ n . ~ 078.249-4-6, ~ r e l . ~ I v a n ~ S a r t o r i, ~ j . ~ 10-06-99 . ~}$
} 
Sendo assim, se a associação não pode cumprir as finalidades para as quais foi instituída, bem como se os seus administradores atuarem com excesso de poderes em desrespeito ao estatuto da associação, ela não poderá cobrar as contribuições de seus associados e o seu patrimônio deverá ser liquidado ${ }^{799}$. Considera-se que o Ministério Público possui interesse em demonstrar o desvio de finalidade da associação ${ }^{800}$.

\section{V.3. Proibição aos administradores de efetuar novas operações}

Durante a fase liquidatória os administradores devem praticar apenas os atos necessários à liquidação do patrimônio do ente coletivo, não podendo celebrar novos negócios jurídicos, que não sejam referentes a operações já em curso, pois seriam incompatíveis com a finalidade de tal procedimento.

O artigo 29 do Código Civil italiano dispõe que os gestores não podem praticar novas operações assim que lhes for comunicado o provimento que declarar a extinção da pessoa jurídica ou da autoridade que determinar a dissolução da associação ou tão logo for tomada a deliberação pela assembleia. Em caso de violação do preceito, os administradores ficarão sujeitos à responsabilidade pessoal e solidária.

A proibição aos dirigentes de efetuar novas operações, segundo M. BASILE, se inicia a partir da comunicação do provimento que declarar a extinção da personalidade jurídica do ente, daquele com o qual a autoridade ordenar a dissolução da associação ou a partir do momento que for aprovada pela assembleia a deliberação de dissolução da entidade. Para o autor, só podem ser praticados atos de administração ordinária, tendentes à mera gestão e conservação do patrimônio ${ }^{801}$.

Caso os gestores violem a regra acima, assumirão responsabilidade pessoal e solidária pelos negócios praticados ${ }^{802}$.

\footnotetext{
${ }^{798}$ TJMG, $7^{\text {a }}$ Câm. Cível, Agravo n. 2.000.000.428.994-3-000, rel. D. Vicoso Rodrigues, j. 29-04-2004.

${ }^{799}$ TJMG, 5a Câm. Cível, Apel. Cível n. 1.070.207.381.233-2-003, rel. Nepomuceno Silva, j. 01-07-2010 e TJMG, 17ª Câm. Cível, Apel. Cível n. 1.002.401.031.928-3-001, rel. Eduardo Marine da Cunha, j. 02-042009.

${ }^{800}$ TJSP, $1^{\text {a }}$ Câm. Dir. Privado, Apel. Cível n. 242.224-4-2-00, rel. Paulo Eduardo Razuk, j. 10-12-2009.

${ }^{801}$ Le Persone giuridiche cit. (nota 54 supra), pp. 406-407.

${ }^{802}$ Cf. M. BASILE, Le Persone giuridiche cit. (nota 54 supra), p. 407.
} 
Os atos definidos como novas operações não vinculam o ente. O terceiro contratante não poderá agir contra este nem se ignorava, sem culpa, a causa superveniente de extinção ${ }^{803}$.

Segundo F. GALGANO a declaração governativa de extinção nas sociedades ou a deliberação de dissolução nas associações determina o direcionamento do escopo do ente para a preparação e realização da liquidação. Os administradores não poderiam executar novas operações, ou seja, praticar atos que não sejam compatíveis com a finalidade da liquidação ${ }^{804}$.

A doutrina francesa, ao tratar das sociedades - cujas normas são de aplicação subsidiária às associações -, explica que a partir da dissolução a personalidade jurídica se enfraquece, porque subsiste apenas para os fins da liquidação. A entidade somente poderá continuar a executar os contratos já em curso, e não poderá praticar novas operações, a não ser que tenham relação com a liquidação ${ }^{805}$.

Paralelamente ao enfraquecimento da personalidade jurídica, constatou-se um renascimento da aplicação das técnicas contratuais. Assim, as relações contratuais entre os sócios ou associados são importantes durante os períodos marginais da vida da sociedade ou da associação, enquanto que durante a maior parte do seu funcionamento utilizam-se as técnicas da pessoa jurídica ${ }^{806}$.

No direito português, depois de dissolvida, a associação fica também limitada à prática de atos meramente conservatórios e dos necessários à liquidação do patrimônio social e ultimação dos negócios pendentes ${ }^{807}$.

Apesar de não haver proibição expressa do Código Civil brasileiro à prática de novas operações durante a fase de liquidação da associação, concluímos que tal restrição também se aplica, em razão da própria finalidade do procedimento.

\footnotetext{
${ }^{803}$ Cf. M. BASILE, Le Persone giuridiche cit. (nota 54 supra), p. 408.

${ }^{804}$ Persone Giuridiche cit. (nota 57 supra), pp. 419-421.

${ }^{805}$ Cf. Y. GuYON, Les Societés cit. (nota 126 supra), pp. 18-19.

${ }^{806}$ Cf. Y. GuYON, Les Societés cit. (nota 126 supra), p. 19.

${ }^{807}$ Ver F. CARDOSO, Extinção das Pessoas Colectivas cit. (nota 240 supra), p. 52.
} 
V.4. Destinação do patrimônio remanescente. Restituição das contribuições aos associados

O Código Civil brasileiro tratou da destinação dos bens da associação dissolvida, estabelecendo que o remanescente do seu patrimônio líquido será destinado a entidade de fins não econômicos, designada no estatuto ou, omisso este, por deliberação dos associados, à instituição municipal, estadual ou federal, de fins idênticos ou semelhantes.

As quotas ou frações ideais dos associados poderão ser deduzidas para se apurar o remanescente do patrimônio líquido da associação, ou seja, os membros, antes de dar a destinação fixada para o acervo remanescente, poderão se ressarcir das contribuições que tiverem efetuado ao patrimônio da entidade dissolvida ${ }^{808} 809$.

Inexistindo no Município, no Estado, no Distrito Federal ou no Território em que a associação tiver sede, instituição municipal, estadual ou federal, de fins não econômicos, idênticos ou semelhantes à associação dissolvida, o remanescente de seu patrimônio líquido deverá ser devolvido à Fazenda do Estado, do Distrito Federal ou da União $^{810}$.

As contribuições dos membros ao patrimônio da entidade, devidamente atualizadas, poderão ser restituídas a eles, desde que haja previsão no estatuto ou por deliberação dos próprios associados ${ }^{811}$.

J. E. S. PAES explica que a restituição das contribuições dos associados é uma inovação do Código Civil de 2002, devendo ser efetuada antes da distribuição do remanescente do patrimônio ${ }^{812}$.

\footnotetext{
${ }^{808}$ Ver o artigo 61 caput do Código Civil.

${ }^{809}$ Cf. C. Bevilaqua, Código Civil do Brasil cit. (nota 18 supra), pp. 189-190, o Código Civil de 1916 já dispunha que o destino dos bens da associação deveria ser previsto no estatuto e, somente na sua omissão, seria aplicada a lei: "Dissolvida a sociedade de intuitos não econômicos, por qualquer das causas constantes do art. 21, procede-se à sua liquidação, isto é, apuram-se os haveres sociais, solvem-se as responsabilidades da pessoa extinta, ultima-se a operações em andamento. Depois atende-se ao que os estatutos determinem, quanto ao destino dos bens, para cumprirem as suas determinações. É ocioso indagar se o preceito dos estatutos deve ser inicial, isto é, estabelecido com a organização da sociedade, ou se foi adotado, ulteriormente. Deve é estar vigorando no momento, em que a sociedade se dissolve.Tem, aqui, o mesmo valor de um preceito dos estatutos, a deliberação tomada pelos sócios, quer antes da dissolução da sociedade, quer no período de liquidação. É somente na falta de uma resolução tomada pelos associados, que a lei, supletivamente, providencia sobre o destino do patrimônio social. Não exige o Código unanimidade para a deliberação dos associados a respeito; consequentemente, basta que a maioria resolva. Deve, porém, a deliberação ser eficaz, isto é, sem vício que perturbe a manifestação jurídica da vontade.No silêncio dos estatutos e na ausência de deliberação dos sócios, o patrimônio da sociedade extinta devolve-se a um estabelecimento de fins idênticos ou semelhantes. (...)"

${ }^{810}$ Ver o parágrafo $2^{\circ}$ do artigo 61 do Código Civil.

${ }^{811}$ Ver o parágrafo $1^{\circ}$ do artigo 61 caput do Código Civil.
} 
No direito italiano, os bens da pessoa jurídica que sobrarem após a conclusão da liquidação também deverão ser devolvidos de acordo com o previsto no ato constitutivo e estatuto. Em caso de omissão, devem ser observadas as deliberações das assembleias que estabeleceram a dissolução e, se nada for deliberado, a autoridade governativa atribuirá os bens a entidades com fins análogos ${ }^{813}$.

A doutrina italiana sustenta que é possível, nas cláusulas estatutárias ou na deliberação assemblear relativa à devolução dos bens, prever a devolução do patrimônio remanescente aos associados. Para outros, a autonomia dos privados pode apenas designar o ente de finalidade análoga que receberá os bens, pois se entendia que a devolução "interessada" deles era impedida pelas normas legais, que negavam ao retirante ou a seus herdeiros os direitos sobre o patrimônio da associação ${ }^{814}$.

O artigo 31 do Código Civil italiano estabelece que a devolução dos bens deve ser feita conforme determinado no ato constitutivo ou no estatuto. Em caso de omissão, para as associações, se observarão as deliberações da assembleia que deliberou pela dissolução e, na ausência desta, a autoridade governativa o estabelecerá.

Os credores que durante a liquidação não tiverem pleiteado os seus créditos, poderão pleitear o pagamento perante aqueles aos quais os bens foram restituídos, até um ano após o encerramento do procedimento, na proporção e nos limites que tiverem recebido.

F. GALGANO ressalta que apenas na omissão das cláusulas estatutárias ou das deliberações assembleares a autoridade deverá destinar os bens remanescentes a outros entes de finalidades análogas. O contrato de associação ou a deliberação de dissolução não podem, contudo, dispor que os bens remanescentes sejam distribuídos entre os $\operatorname{associados}^{815}$.

No direito francês, a Lei de 01.07.1901 estabeleceu, em seu artigo $9^{\circ}$, que no caso de dissolução os bens da associação serão devolvidos conforme disposto nos estatutos, ou, na omissão desses, de acordo com os usos do local da sede. Aplicam-se subsidiariamente as normas sobre sociedades.

\footnotetext{
${ }^{812}$ Fundações, Associações e Entidades cit. (nota 32 supra), p. 184.

${ }^{813}$ Ver M. BASILE, Le persone giuridiche cit. (nota 54 supra), pp. 413-414.

${ }^{814}$ Ver M. BASILE, Le persone giuridiche cit. (nota 54 supra), pp. 414-417.

${ }^{815}$ Persone giuridiche cit. (nota 57 supra), pp. 426-429.
} 
A divisão dos bens é regulada de forma diversa conforme a pessoa jurídica possua ou não finalidade lucrativa. Nas últimas, os membros não recebem os bens de volta, que devem então ser devolvidos de acordo com as previsões estatutárias, ou na omissão, conforme determinado em assembleia geral, de preferência a outra entidade com fins semelhantes à dissolvida ${ }^{816}$.

No direito alemão, a liquidação visa preservar o interesse dos credores antes de repartir o patrimônio restante. Em todos os casos de dissolução ou perda da capacidade jurídica o patrimônio deve ser transmitido às pessoas determinadas ou determináveis pelo estatuto. Na sua omissão, se decide em função da finalidade da associação ${ }^{817}$.

No direito português, de acordo com F. CARDOSO, o destino do patrimônio das associações será atribuído pela autoridade judiciária, com o mesmo encargo ou afetação, a outra pessoa coletiva. Em relação ao poder de destinação quanto a outros bens, há uma hierarquia a se respeitar: lei especial, estatutos, deliberação dos associados e autoridade judiciária. A assembleia geral da pessoa jurídica pode dispor a favor de outra pessoa jurídica, desde que a segunda assegure a realização do fim perseguido pela primeira $^{818}$.

Portanto, no direito brasileiro, notamos uma autonomia dos associados para dispor acerca da devolução de suas contribuições em caso de extinção da associação, seja por inserção de cláusula estatutária, seja por tomada de deliberação assemblear, o que não é encontrado da mesma forma em outras legislações.

A jurisprudência brasileira já decidiu que a entidade dissolvida poderá destinar o seu patrimônio líquido para outra de idênticos fins, devendo a beneficiária ser prevista no estatuto ou escolhida pelos associados. Contudo, uma associação interessada no patrimônio líquido de outra não poderá requerer em juízo a aquisição dos bens. Considerase que a destinação do patrimônio líquido é ato vinculado à competência estatutária, e ao Poder Judiciário cabe zelar pelo cumprimento do que foi deliberado no estatuto, ou pelos associados para tal desiderato $^{819}$.

\footnotetext{
${ }^{816}$ Cf. B. TeYssiÉ, Personnes Juridiques cit. (nota 38 supra), p. 550.

${ }^{817}$ Ver F. KüBLER, Derecho de Sociedades cit. (nota 61 supra), pp. 223-224.

${ }^{818}$ Extinção das Pessoas Colectivas cit. (nota 240 supra), pp. 57-59. A deliberação sobre o destino dos bens deve ser tomada antes da extinção propriamente dita da pessoa jurídica, até no máximo na própria assembleia que deliberou a extinção, em razão da limitação de sua capacidade durante a fase de liquidação.

${ }^{819}$ TJMG, $2^{\mathrm{a}}$ Câm. Cível, Apel. Cível n. 1.042.903.002.805-5-001, rel. Nilson Reis, j. 31-10-2006.
} 
Assim, uma entidade benemerente diversa que almeja receber o patrimônio da associação a ser dissolvida, não poderá fazê-lo em violação ao disposto no estatuto e nem pleitear a sua dissolução ${ }^{820}$.

Em caso de omissão do estatuto acerca a destinação do patrimônio remanescente e na ausência de deliberação dos associados, ele será revertido a um estabelecimento municipal, estadual ou federal, de fins idênticos ou semelhantes ${ }^{821}$.

É nula, ante a flagrante violação à norma cogente contida no caput do artigo 61 do CC, a disposição do estatuto da entidade que estabelece que o patrimônio remanescente da associação será rateado entre os associados, impondo-se que, em observância à lei, sejam restituídas as quotas dos sócios efetivamente patrimoniais, destinando-se o patrimônio remanescente a instituição municipal, estadual ou federal, de fins idênticos ou semelhantes ao da entidade dissolvenda ${ }^{822}$.

${ }^{820}$ TJSP, 4 a Câm. Dir. Privado, Apel. Cível n. 994.09.287.598-8, rel. Francisco Loureiro, j. 5-8-2010.

${ }^{821} S T F, 2^{\text {a }}$ Turma, R. Ext. n. 99.343-6, rel. Carlos Madeira, j. 11-3-86.

${ }^{822}$ TJRS, $5^{\text {a }}$ Câm. Cível, Apel. Cível n. 70.024.200.750, rel. Paulo Sérgio Scarparo, j. 18-06-2008. 


\section{CONCLUSÃO}

As associações são pessoas jurídicas de direito privado, juntamente com as sociedades, as fundações, as organizações religiosas e os partidos políticos. Trata-se uma reunião de indivíduos, que aderem livremente a elas, visando alcançar objetivos comuns, não lucrativos, através de contribuições, que podem ser ou não pecuniárias e constituem o patrimônio da entidade.

As associações e sociedades são modalidades de pessoas jurídicas do tipo corporativo, distinguindo-se das fundações. Em ambas, os membros unem seus esforços para alcançar finalidades comuns. As primeiras não possuem finalidade lucrativa enquanto as segundas as têm.

É proibida a distribuição de lucros entre os associados e gestores. Podem ser praticadas operações para obter lucro e aumentar o patrimônio do ente, desde que tais proveitos sejam reinvestidos para o alcance das finalidades.

Os membros possuem liberdade para criar os seus estatutos e regular a organização interna da associação, inserindo as disposições que entenderem pertinentes, desde que não sejam contrárias à lei.

Não existem direitos e obrigações recíprocos entre os associados, e sim apenas entre os membros e o ente.

O elemento de destaque das associações é o pessoal, enquanto das fundações é o material. As primeiras não necessitam de patrimônio para se constituir, embora, posteriormente, possam ser necessários bens para a sua manutenção. Tanto os elementos pessoais quanto os patrimoniais estão presentes em ambas, variando a sua importância em cada espécie.

As associações são vistas como uma coletividade de pessoas, administrada pelos próprios membros, cujos interesses perseguidos são escolhidos por eles e podem ser alterados. Já as fundações são vistas como um grupamento de bens, cujos fins são aqueles almejados pelo fundador, perenes e imutáveis.

Os órgãos das associações são denominados dirigentes ou dominantes, pois os associados deliberam livremente, enquanto que os das fundações são conhecidos como servientes, pois as suas resoluções são delimitadas pelo instituidor. 
O fim das associações deve ser determinado no seu estatuto, indicando a atividade do ente, pelo menos a principal, e evidenciando o interesse cuja realização é perseguida através dela. Deve ser determinado e duradouro, podendo ser múltiplos, desde que homogêneos e conciliáveis.

Embora não possa haver distribuição de lucro entre os associados e os administradores, as entidades podem exercer atividades econômicas, de forma direta, através da produção e troca de bens e serviços ou indireta, com a aquisição, por exemplo, de quotas ou ações de sociedades. Contudo, os proveitos obtidos deverão ser destinados aos fins do ente.

$\mathrm{Na}$ França, muitas associações exercem atividades econômicas. Denominam-se associações empresariais e possuem estatutos de associações, embora as suas atividades combinadas à sua estrutura e gestão financeira pertençam às empresas, o que faz com que se submetam a regras muitas vezes conflituosas.

Apesar da Lei francesa de 1901 não ter preparado tais entidades para o exercício de atividade econômica, a jurisprudência já reconheceu esta possibilidade. Contudo, o estatuto associativo não parece ser a forma jurídica desejável para tanto.

Esses entes não possuem capital social e fundos próprios, enfrentando problemas de gestão e de financiamento equivalentes aos das sociedades empresárias.

Sendo assim, entendemos que uma associação que evolui no sentido de uma sociedade empresária deveria poder deliberar a formalização dessa transformação. Contudo, isso não se admite, sendo necessária a dissolução da entidade ou ainda a criação de uma sociedade em paralelo, podendo a primeira se tornar sócia da última.

Entendemos ser oportuno que os associados possam incluir nos estatutos disposições permitindo às associações emitir títulos, participar de grupos e realizar investimentos no mercado financeiro, em especial se tratando de entidades que realizem atividades de grande alcance social e que necessitem de formas de financiamento viáveis para a consecução do seu escopo.

Normalmente o ato constitutivo e o estatuto são redigidos em documentos separados, embora possam estar no mesmo. O primeiro contém a manifestação da vontade das partes de criarem a relação enquanto o segundo é o conjunto de normas de organização e funcionamento do ente. Devem conter os seus elementos essenciais, sob pena de nulidade. 
Os referidos elementos são: a denominação; os fins; a sede; os requisitos para admissão, demissão e exclusão dos associados; os direitos e deveres dos membros; normas sobre a organização e administração; as fontes de recursos para a sua manutenção; o modo de constituição e funcionamento dos órgãos deliberativos; as condições para alteração das disposições estatutárias e para a dissolução; a forma de gestão administrativa e de aprovação das contas.

$\mathrm{O}$ ato constitutivo e o estatuto vinculam não só aqueles que participaram da constituição da entidade, como também os futuros integrantes, que a ela aderirem na constância de seu funcionamento.

As alterações estatutárias deverão obedecer ao quanto nele disposto para proceder à reforma, em relação ao procedimento e aos quoruns necessários. Normamente tal deliberação é atribuída à assembleia.

Podem ser previstas diversas categorias de associados, com direitos e deveres diversos para cada uma, vantagens ou restrições, o que não viola o princípio da igualdade.

Da relação jurídica de membridade surgem direitos, pretensões, deveres e obrigações, sendo que alguns destes são específicos. Aqueles que conferem vantagens especiais a determinados membros são denominados específicos preferentes, que também não violam o princípio da igualdade, embora tenham nascido da desigualdade.

Alguns direitos são inerentes ao conteúdo legal do tipo associativo, não necessitando de previsão. O direito de voto pode ser concedido ou negado e o direito de retirada pode também sofrer exceções.

As obrigações podem ser gerais ou específicas, comuns a todos os membros; e sociais ou especificas excepcionais, conferidas apenas a alguns deles. Uma das obrigações dos associados é a contribuição.

Os membros devem ser tratados com igualdade em todos os órgãos da entidade, a não ser que os demais decidam o contrário e o que será tratado desigualmente assentir.

A qualidade do associado é intransmissível, inter vivos e mortis causa, salvo se o estatuto dispuser de forma diversa. 
Podem ser estabelecidos limites e condições à admissão de novos membros. Parece não haver um direito subjetivo de admissão a quem possuir os requisitos previstos pelo legislador ou pela autonomia coletiva dos associados. Para tanto, não poderia haver discricionariedade na análise do requerimento de terceiro.

Destacamos, no presente estudo, as organizações não governamentais (ONGs), que assumem a forma de associações sem fins lucrativos ou fundações, em razão do seu papel relevante na economia, em especial como complemento das atividades do Estado.

Talvez a inexistência de uma legislação específica sobre essas entidades tenha acarretado a necessidade de reforma da disciplina das associações, com a criação de um modelo de administração e controle adequado para as organizações não governamentais, ainda mais considerando que algumas passaram a exercer atividades de empresa.

A existência legal das associações se inicia com a inscrição do ato constitutivo no seu respectivo registro. Aquelas que não se inscreverem serão irregulares ou não personificadas, mas existem de fato. $O$ registro tem como finalidade dar publicidade da constituição das entidades.

As associações cujo objeto compreenda a prática de atividade ilícita, contrária ao bem público, à segurança do Estado ou da coletividade, à ordem pública, à moral e aos bons costumes não poderão ser inscritas. Não cabe à autoridade administrativa, porém, efetuar um controle de mérito dos escopos dos entes.

O requerimento de registro poderá ser rejeitado se o estatuto não contiver os elementos essenciais da associação, já citados.

As alterações do ato constitutivo e do estatuto, a transferência da sede, a substituição dos administradores, a indicação dos representantes, as deliberações de dissolução e liquidação, bem como o nome dos liquidantes também deverão ser inscritos no registro, sob pena de não serem oponíveis a terceiros.

O legislador brasileiro não tratou das associações não personificadas como fez o italiano. Isso gera dúvidas acerca do regime jurídico aplicável a elas, em especial no tocante à capacidade e à responsabilidade dos membros. 
Entendemos que o patrimônio das associações não reconhecidas é de titularidade de todos os associados em comum e que as pessoas que tiverem agido em nome e por conta dessas entidades devem responder solidariamente e ilimitadamente pelas suas obrigações. Já os associados não responderiam pessoalmente, devendo os credores agir sobre o fundo comum ou pessoalmente contra os representantes do ente.

No direito italiano existe uma tendência a equiparar as associações não reconhecidas às reconhecidas, tendo as diferenças entre elas sido revistas, concedendo às primeiras uma subjetividade semelhante à das últimas.

As associações que adquirem a personalidade jurídica com o registro possuirão um patrimônio separado, distinto daquele pertencente aos membros, constituindo tais entidades sujeitos de direitos e de obrigações.

Adquirem também titularidade processual e responsabilidade patrimonial, respondendo com o seu patrimônio - que é distinto daquele dos associados - pelas obrigações que assumir.

A natureza jurídica do ato constitutivo das associações é controvertida. Para alguns é ato coletivo e para outros, contrato.

A doutrina italiana solucionou as hesitações em aplicar as regras dos contratos - normalmente fundadas no tipo de troca - para as associações com a figura do contrato plurilateral aberto à adesão de novos associados, com comunhão de escopo.

Tal figura admite o ingresso, numa relação contratual, de outros sujeitos diferentes das partes iniciais. Os interesses não são contrapostos, e sim convergentes. O escopo comum é o elemento unificador das várias adesões. A entrada de novos membros não implica em modificação do contrato originário. O interesse das partes se alcança com o desenvolvimento das atividades a cujas prestações são preordenadas.

A maioria da doutrina entende, com fundamento na autonomia privada, que o aderente não é titular de um direito subjetivo de entrar e fazer parte do ente já constituído, quando possuir as características pessoais indicadas na cláusula de adesão e tiver observado todas as regras procedimentais previstas pela associação para efetivação do ato.

Admitia-se, porém, que essas espécies possuíam algumas peculiaridades, como a participação de duas ou mais partes, assumindo todas elas direitos e obrigações. 
Em relação à constituição, uma manifestação viciada não necessariamente anularia todo o contrato. $\mathrm{O}$ ato constitutivo possui eficácia em relação a outros sujeitos além dos originais.

Consequentemente, a disciplina dos contratos deveria ser adaptada às especificidades de cada tipo negocial.

Contudo, questionamos se o ato constitutivo das associações pode possuir a natureza de contrato, tendo em vista que não constitui ou regula relações jurídicas patrimoniais.

Essa crítica foi respondida da seguinte forma: a área do contrato, enquanto circunscrita às relações jurídicas patrimoniais, não coincidiria com a esfera de interesses patrimoniais ou dos escopos econômicos. Sendo assim, a patrimonialidade da relação não dependeria da natureza do interesse perseguido pelas partes, que poderia ser também não patrimonial, mas se determina em razão do fato de que as prestações das partes sejam suscetíveis de avaliação econômica.

Outra dificuldade colocada era que o contrato era visto como um instrumento para regular interesses contrapostos e não paralelos. Contudo, o conflito de interesses existe também entre os associados nas sociedades e associações, unificando-se por visarem a alcançar um escopo comum.

Lembramos, ainda, que no direito italiano o contrato foi colocado como categoria geral, no lugar do negócio jurídico, apesar da doutrina admitir a existência das duas figuras.

Para nós, a maior dificuldade em classificar a associação brasileira como contrato está no conteúdo do art. 53 do Código Civil, que dispõe inexistirem entre os associados direitos e obrigações recíprocos, pois num contrato plurilateral todas as partes seriam titulares de direitos e obrigações, sendo que cada uma possui obrigações para com todas as outras. Na associação brasileira, as obrigações existem somente entre associados e o ente, e não entre os membros entre si.

Defendemos que a associação, expressão da autonomia negocial, surge através de um negócio jurídico de organização, cuja execução implica na criação de uma estrutura organizativa. Uma vez constituída a relação associativa, as pretensões dos associados são dirigidas à entidade, e não aos demais membros. 
Os associados possuem autonomia para escolher as regras que adotarão para reger a entidade, que resta consagrada no negócio constitutivo e nos atos executados por órgãos do ente, como estatutos e regulamentos. Tais regras são de várias formas condicionadas pela intervenção legislativa, quer na sua existência, quer no seu conteúdo.

As pessoas jurídicas não podem agir por si, então o fazem através de seus órgãos. Existem órgãos colegiais, providos de funções deliberativas, e individuais, com funções executivas e de representação externa. Os atos por ele praticados são imputados à entidade, desde que dentro das competências atribuídas e se exercidos em nome dela, e não a título pessoal.

O modo de constituição e funcionamento dos órgãos deliberativos deve estar previsto no ato constitutivo, bem como a forma da gestão administrativa e a aprovação das respectivas contas.

São órgãos necessários a assembleia e a diretoria e, para alguns, também o conselho fiscal, sendo os demais, como o conselho de administração ou deliberativo, facultativos.

A diretoria normalmente não é um órgão colegiado, mas o estatuto pode prever que algumas decisões sejam tomadas em reunião. Já o conselho de administração ou deliberativo é necessariamente colegiado e delibera por maioria. Podem ser criados outros órgãos de controle e de resolução de controvérsias internas.

A assembleia é o órgão soberano, composto por todos os associados, que nomeia e destitui os administradores e pode fixar diretrizes sobre a gestão da entidade e aprovar ou não os critérios adotados. A administração direta, contudo, cabe ao órgão administrativo.

São competências exclusivas da assembleia a modificação do ato constitutivo e do estatuto; a dissolução e a devolução do patrimônio; a maior parte das atividades organizativas, incluída a exclusão dos associados; a nomeação e destituição dos administradores e os atos gerais de gestão, como a aprovação do balanço.

Nos casos de destituição dos administradores e alteração do estatuto social hipóteses de competência privativa da assembleia - ela deverá ser especialmente convocada para esses fins, devendo o estatuto estabelecer o quorum para a tomada de tais deliberações. As deliberações são normamente tomadas por maioria, podendo o estatuto prever outros quorum, inclusive a unanimidade. 
A convocação normalmente é efetuada pela diretoria ou outro órgão encarregado, mas pode também ser efetuada por um quinto dos associados.

Em princípio todos os associados possuem o direito de votar nas assembleias, salvo se estiverem inadimplentes em relação às contribuições. As deliberações regularmente tomadas vinculam a todos, inclusive os ausentes e dissidentes.

As deliberações assembleares contrárias à lei ou aos estatutos são anuláveis, podendo a sua anulação ser pleiteada por todos os associados que discordarem dela, pelos órgãos do ente, pelo terceiro prejudicado e pelo Ministério Público. A ação deverá ser proposta contra a associação.

A anulação não prejudica os direitos adquiridos pelos terceiros de boa-fé com fundamento nos atos praticados em execução da própria deliberação.

Poderão ser nulas em outras hipóteses, como quando forem tomadas por maioria, quando se exige unanimidade; por órgão deliberante diferente da assembleia; quando forem lesivas aos direitos individuais dos associados, podendo a ação ser proposta por qualquer membro ou interessado, sempre em face da entidade.

Caso a deliberação seja ilícita, ou seja, quando violar ou mirar a contornar normas inderrogáveis que limitem os interesses perseguíveis ou a atividade pela qual estes seriam alcançados, será também nula. Além da violação a normas imperativas, a nulidade será cabível nos casos de contrariedade à ordem pública e aos bons costumes e de impossibilidade ou ilicitude do objeto.

A impugnação é admitida por questões de legitimidade e não se poderá discutir o mérito da deliberação, a não ser que seja necessário para apreciar a ocorrência de um vício de legitimidade, em especial em hipóteses de excesso ou abuso de poder da maioria, quando os interesses buscados não forem os da associação. Não poderá haver um exame da sua conveniência e oportunidade.

A disciplina dos contratos parece parcialmente aplicável às deliberações assembleares. Para as associações não reconhecidas as mesmas regras são aplicáveis.

Entendemos que a disciplina do conflito de interesses das sociedades anônimas deve ser aplicada para os administradores e membros das associações. Sendo assim, quando o associado não for independente em relação à matéria discutida na 
assembleia, podendo influenciar nas decisões ou tomá-las motivado por interesses distintos daqueles da associação, não deverá participar da deliberação.

Considerar-se-á abusivo o voto exercido com o fim de causar dano à entidade ou a outros membros, ou de obter, para si ou para outrem, vantagem a que não faz jus e de que resulte, ou possa resultar, prejuízo para o ente ou para outros membros. $\mathrm{O}$ associado responderá pelo exercício abusivo do seu direito de voto, ainda que ele não tenha prevalecido.

A deliberação tomada em decorrência do voto do associado que possuir interesse conflitante com o da associação será anulável, respondendo ele pelos danos causados e sendo obrigado a transferir para a entidade as vantagens que tiver auferido.

Os administradores do ente não poderão votar nas deliberações referentes à sua responsabilidade ou intervir naquelas que possuírem interesse conflitante com o da entidade. Somente poderão contratar com ela em condições razoáveis ou equitativas, idênticas às que prevaleceriam no mercado ou em que se operariam com terceiros, sob pena de anulação do negócio, obrigando-se o gestor a transferir ao ente as vantagens que tiver auferido.

A diretoria é o órgão responsável pelo funcionamento da associação, devendo dirigi-la de acordo com as normas contidas no estatuto e instruções dadas pela assembleia.

Suas deliberações são tomadas normalmente pelo princípio majoritário, salvo se o estatuto estabelecer de forma diversa.

Os diretores podem ser destituídos pela assembleia, por unanimidade, ou por maioria, conforme previsto, operando a destituição ex nunc. O estatuto deverá estabelecer se haverá necessidade de motivação.

A assembleia poderá intervir sobre os gestores, fixando diretrizes gerais ou mesmo dando ordens concretas acerca do cumprimento de determinada operação.

Uma vez nomeados, os administradores exercem poderes e cumprem as suas obrigações, devendo exercer a gestão no interesse da associação, de acordo com os seus fins. São imputados a eles os deveres de diligência e de lealdade. Exercem a representação da entidade, salvo disposição diversa do estatuto. 
É admitida a impugnação às deliberações dos órgãos administrativos, por parte dos próprios gestores, associados e conselho fiscal.

Os administradores são responsáveis pelos atos por eles praticados em relação à associação, podendo ainda responder perante terceiros.

Os atos de gestão que não forem praticados em conformidade com os deveres dos dirigentes ou a completa omissão daqueles devidos constituem inadimplemento. Se produzirem danos à associação, haverá obrigação de ressarci-los, desde que a execução fosse possível, ou ainda se se tornou impossível por um fato imputável a eles.

O caráter colegial do dever de gestão comporta que a sua inobservância seja um ilícito coletivo, ocorrendo inadimplemento de todos os membros do órgão. Há, contudo, exceções. Se for um ato comissivo, a responsabilidade será somente dos que agiram, mas aqueles que tinham ciência deverão registrar a sua discordância para não serem responsabilizados.

O dano a ser ressarcido compreende as perdas e o lucro cessante que forem consequências imediatas e diretas do inadimplemento. A obrigação dos administradores de ressarcimento é solidária. Valem os princípios gerais também para o exercício das ações de responsabilidade. Cabe à associação o ônus da prova do inadimplemento e do dano. Os gestores somente podem se eximir da condenação se demonstrarem a impossibilidade do adimplemento, a sua independência em relação a ele ou a ausência de dano.

Nas associações não reconhecidas, respondem também pessoalmente e solidariamente as pessoas que agirem em nome e por conta delas.

$\mathrm{O}$ ato constitutivo e o estatuto das associações podem prever a criação de outros órgãos, determinando a sua composição e as suas competências, que podem ser retiradas daquelas confiadas pela lei às assembleias ou aos administradores. Trata-se de órgãos de disciplina e de justiça interna e de resolução de controvérsias e de controles internos.

O conselho fiscal - existente na maior parte das associações brasileiras tem como competência a fiscalização da sua gestão econômico financeira. 
As condições de alteração dos estatutos - inclusive o quorum para aprovação da deliberação - devem estar neles previstas e são de competência privativa da assembleia geral, que deverá ser convocada especialmente para esse fim.

Em razão do preceito constitucional de liberdade de associação, os associados possuem o direito de se retirar da entidade, podendo o estatuto estabelecer exceções. As restrições mais comuns colocadas são temporais. Seus efeitos são a extinção dos direitos organizativos.

O estatuto deve conter os requisitos sobre a exclusão dos associados, sob pena de nulidade. Será admissível desde que haja justa causa, assim reconhecida em procedimento que assegure o direito de defesa e de recurso.

A expulsão é exercício da função disciplinar dos órgãos, que lhes permite aplicar aos membros punições ou penas, que variam desde a simples advertência e suspensão até a exclusão.

A justa causa normalmente está ligada ao descumprimento dos deveres estatutários, podendo também a quebra de affectio societatis, o descumprimento do dever de colaboração e a perda dos requisitos de admissão previstos no ato constitutivo constituirem motivos para a expulsão. A sua indicação nos estatutos pode ser exemplificativa ou taxativa, ou pode ainda ser feita por meio de normas programáticas, com diretrizes a serem realizadas por outros órgãos do ente.

A deliberação pode ser anulada caso determine a exclusão de forma unilateral, sem permitir ao associado o exercício do seu direito de defesa.

O associado poderá discutir a regularidade formal da exclusão e o seu mérito, em especial a presença dos graves motivos necessários. O juiz não deve analisar o mérito propriamente dito da deliberação, e sim verificar se não houve abusos por parte da maioria, no sentido de exercer o poder fora da forma prevista em lei e no estatuto, além de verificar se o membro praticou o ato a ele imputado e se tal ato se enquadra nas hipóteses de justa causa. Não deve apreciar a conveniência e oportunidade da deliberação.

O STF aplicou à exclusão dos associados os princípios constitucionais do contraditório e da ampla defesa, atribuindo eficácia a esses direitos fundamentais nas relações privadas. 
As condições de dissolução da associação e o destino de seu patrimônio devem estar previstos no seu ato constitutivo ou estatuto.

A dissolução é uma fase da extinção, tida como necessária, mas nem sempre suficiente à última. Considera-se a extinção um efeito da dissolução. Durante a dissolução a pessoa jurídica possui uma capacidade limitada de agir. Esta fase é preparatória à fase de liquidação. As fases do processo de extinção são, portanto: dissolução, liquidação e extinção stricto sensu.

A personalidade jurídica das associações persiste até o fim da sua liquidação, desaparecendo apenas com a extinção propriamente dita do ente coletivo.

A dissolução se distingue da anulação ou invalidade, quando existe um vício na própria constituição do ente coletivo. Não fulmina o ato constitutivo, e sim o modifica, dando início à liquidação, que envolve a terminação dos assuntos em que a pessoa jurídica estava envolvida e a apuração final de seus bens. Somente ao final se obtém o cancelamento do ente, cessando a personalidade jurídica com o registro do encerramento da liquidação.

Dissolvido o ente coletivo, deve-se determinar quem lhe sucede no acervo patrimonial apurado na fase de liquidação.

Os liquidantes deverão ser nomeados pela assembleia que deliberou pela dissolução ou por alguma outra forma, estabelecida no estatuto.

É especial das corporações, como as associações, o modo de extinção que se verifica pela falta do elemento pessoal: morte, recesso, demissão ou exclusão de todos os membros, pela saída de alguns ou de apenas um, se não for possível a sua substituição, por guardar vínculo pessoal com o ente.

A falta do elemento material a princípio não seria motivo para a extinção, a não ser que sem o patrimônio a entidade não possa atingir o seu fim.

A dissolução pode ser deliberada também pela assembleia de associados. Outras causas seriam: o fim do prazo fixado no estatuto, obtenção do fim ou impossibilidade superveniente de obtê-lo. Por fim, há forma judicial, decretada pelo juiz e por iniciativa de qualquer associado e a dissolução por ato governamental, com a cassação da autorização de funcionamento, por não atender às suas finalidades ou por exercer atividades nocivas ao bem público. 
O quorum para deliberar a dissolução deve ser de maioria absoluta dos membros, salvo se o estatuto dispuser de forma diversa.

Durante a fase liquidatória os administradores podem praticar os atos necessários à liquidação do patrimônio do ente, não podendo celebrar novos negócios, tidos como incompatíveis com a finalidade do procedimento.

Em caso de violação, ficarão sujeitos à responsabilidade pessoal e solidária. Os atos definidos como novas operações não vincularão a entidade.

O remanescente do patrimônio líquido da associação dissolvida será destinado a entidade de fins não econômicos, designada no estatuto, ou omisso este, por deliberação dos associados, à instituição municipal, estadual ou federal, de fins idênticos ou semelhantes.

Inexistindo no Município, no Estado, no Distrito Federal ou no Território em que a associação tiver sede, instituição municipal, estadual ou federal, de fins não econômicos, idênticos ou semelhantes à associação dissolvida, o remanescente de seu patrimônio líquido deverá ser devolvido à Fazenda do Estado, do Distrito Federal ou da União.

As quotas ou frações ideais dos associados poderão ser deduzidas para se apurar o remanescente do patrimônio líquido da associação. 


\section{ÍNDICE DAS FONTES}

- Código Civil brasileiro de 1916

- Código Civil brasileiro vigente

- Código Comercial

- Código Civil alemão (Bürgerlichen Gesetzbuch) trad.

- Código Civil italiano

- Constituição Federal

- Lei n. 6.404/76 (Lei das Sociedades Anônimas)

- Lei n. 9.637/98 (Lei das Organizações Sociais)

- Lei n. 9.790/99 (Lei das Organizações da Sociedade Civil de Interesse Público).

- Lei n. 11.127/05 (reformou o Código Civil)

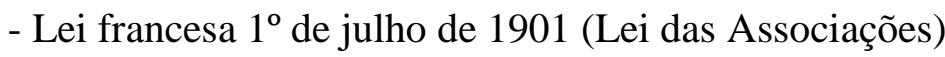

- Lei francesa 84.610/84 (Lei sobre Associações que exercem Atividades Empresárias) 


\section{BIBLIOGRAFIA FINAL (CONSULTADA $)^{823}$}

Amaral, Francisco, Direito Civil - Introdução, 6a ed., Rio de Janeiro, Renovar, 2006.

Ascarelli, Tullio, O Contrato Plurilateral, in Problemas das Sociedades Anônimas e Direito Comparado, São Paulo, Saraiva, 1945.

Ascensão, José de Oliveira, O Direito - Introdução e Teoria Geral - Uma Perspectiva Luso - Brasileira, $2^{\mathrm{a}}$ ed. bras., Rio de Janeiro, Renovar, 2001.

AZEVEDO, Antônio Junqueira de, Negócio Jurídico: Existência, Validade e Eficácia, $4^{\mathrm{a}}$ ed., São Paulo, Saraiva, 2002.

Negócio Jurídico e Declaração Negocial: Noções Gerais e Formação da

Declaração Negocial, Tese (titularidade) - Faculdade de Direito da USP, São Paulo, 1986.

BASILE, Massimo, Le persone giuridiche, Milano, Giuffrè, 2003.

Associazioni, fondazioni e comitati, Rivista di Dirito Civile, anno XXXVI, n. 2, mar./apr. 1990.

Bernardes de Mello, Teoria do Fato Jurídico, 9a ed., São Paulo, Saraiva, 1999.

BESSONE, Mario, Casi e questioni di diritto privato per la pratica forense, Milano, Giuffrè, 1995.

Casi e questioni di diritto privato, I- Persone fisiche e persone giuridiche, $7^{\mathrm{a}}$ ed., Milano, Giuffrè, 1993.

Bevilaqua, Clovis, Código Civil do Brasil comentado por Clovis Bevilaqua, vol.I, 12a ed., Rio de Janeiro, Paulo de Azevedo, 1959.

Braga, Luziânia C. PinheIro, Organizações da Sociedade Civil de Interesse Público (OSCIP): Promoção e Construção de (Novos) Direitos e Assessoria Jurídica de Caráter Suplementar, in Revista de Direito do Terceiro Setor, ano 1, n.1, jan./jul. 2007

Cardoso, Fernando, Extinção das Pessoas Colectivas de Direito Privado, Lisboa, Portugalmundo, 1989.

CARLO, Antonio, Il contratto plirilaterale associativo, Napoli, Eugenio Jovene, 1967.

Castro, Sami, e Alix, Nicole, L'Entreprise Associative - Aspects Juridiques de l'Intervention Économique des Associations, Paris, Economica, 1990.

${ }^{823}$ A metodologia adotada na presente tese foi a sugerida por C. Eduardo Silveira Marchi, na obra entitulada "Guia de metodologia jurídica". O método de citação bibliográfica adotado foi o denominado "francoitaliano". Ver C. E. S. MARCHI, Guia de Metodologia Jurídica, 2a ed., São Paulo, Saraiva, 2009. 
Castro y Bravo, Federico de, La Persona Giuridica, 2a ed., Madrid, Civitas, 1991.

CESARÒ, Ernesto, Contratto aperto e adesione del terzo, Napoli, Jovene Napoli, 1979.

Coelho, Fábio Ulhoa, Curso de Direito Civil, vol. 1, 2ª ed., São Paulo, Saraiva, 2006.

Danielian, Miguel, e Peret, Jose I. Brito, Personas Juridicas, La Plata, Fides, 1973.

Dantas, San Tiago, Programa de Direito Civil - Parte Geral, 4a tir., Rio de Janeiro, Rio, 1979.

Delamarre, Pascal, Créer et faire vivre son Association, Paris, Dalloz, 2004.

Damarey, Stéphanie, et. al., Code des Associations et Fondations - Commenté, Paris, Dalloz, 2008.

De RugGIERO, Roberto, Instituzioni di diritto civile, 1934, trad. port. de Ary dos Santos e revista e adaptada por Antônio Chaves e Fábio Maria de Mattia, Instituições de Direito Civil, vol. I, $3^{\text {a }}$ ed., São Paulo, Saraiva, 1971.

Diniz, Maria Helena, Curso de Direito Civil Brasileiro - 1. Teoria Geral do Direito Civil, $24^{\mathrm{a}}$ ed., São Paulo, Saraiva, 2007.

, Sociedade e Associação, in Yussef Cahali (coord.), Contratos Nominados, São Paulo, Saraiva, 1995.

FERRARA, Francesco, Le persone giuridiche, Torino, Unione Topografico, 1958.

FERRI, Giovanni B., Il negozio giuridico, 2ª ed., Padova, Cedam, 2009. Delle società, $2^{\mathrm{a}}$ ed., Bologna, Nicola Zanichelli, 1968.

Flume, Werner, Allgemeiner Teil des bürgerlichen Rechts - Das Rechtsgeschäft, 1992, trad. esp. de José Maria Miquel González e Esther Gómez Calle, El Negocio Jurídico Parte General del Derecho Civil, tomo segundo, $4^{\mathrm{a}}$ ed., Madrid, Fundación Cultural del Notoriado, 1998.

FRANÇA, Limongi, Instituições de Direito Civil, $3^{\text {a }}$ ed., São Paulo, Saraiva, 1994.

Galgano, Francesco, Persone giuridiche, Bologna, Nicola Zanichelli, 1969. , Il negozio giuridico, $2^{\mathrm{a}}$ ed., Milano, Giuffrè, 2002.

GANGI, Calogero, Persone fisiche e persone giuridiche, 2a ed., Milano, Giuffré, 1948.

GENTIL, Rafael, As Associações e as suas Eleições, Tribuna do Direito, n. 139, nov. 2004.

GIANI, Leonardo, L'amministrazione ed il controllo di associazioni e fondazioni in una prospettiva di riforma, in Rassegna di Diritto Civile, dir. da Pietro Perlingieri, 2007. 
Giovene, Achille, Le associazioni di fatto nel diritto privato, Milano, Dottor Francesco Vallardi, 1914.

GoMes, Orlando, Introdução ao Direito Civil, $7^{\mathrm{a}}$ ed., Rio de Janeiro, Forense, 1983.

Gonçalves, Carlos Roberto, Direito Civil Brasileiro - Parte Geral, vol. I, $2^{\text {a }}$ ed., São Paulo, Saraiva, 2005.

Gonçalves, Luiz da Cunha, Princípios de Direito Civil - Parte Geral, vol. I, São Paulo, Max Limonad, 1951.

GoRga, Érica Cristina Rocha, Direito Societário Brasileiro e Desenvolvimento do Mercado de Capitais: Uma Perspectiva de Direito e Economia, Tese (doutorado) Faculdade de Direito da USP, São Paulo, 2005.

GuYon, Yves, Les Sociétés - Aménagements Statutaires et Convention entre Associés, $2^{\mathrm{a}}$ ed., Paris, LGDJ, 1995.

HANSMAnN, Henry, The ownership of enterprise, Cambridge, Harvard University, 2000.

, Economic theories of nonprofit organization. in W. Powell, The nonprofit sector: a research handbook, Yale University, New Haven, 1987, disponível in www.ssrn.com [05-08-2011]

, Higher education as an associative good, Yale Law School, New Haven, set. 1999, working paper n. 99-15, disponível in www.ssrn.com. [05-08-2011].

The rule of trust in nonprofit enterprise, in Helmut K. Anheier e Avner BenNer, The study of nonprofit enterprise: theories and approaches, New York, Kliuwer Academic, 2003.

The chaniging roles of public, private and nonprofit enterprise in education, health care and other human services, in V. FUCHS, Individual and social responsibility; child care, education, medical care, and long-term care in America, NBER, University of Chicago, s.d., disponível in www.yale.edu [05-08-2011].

, KeSSLER, Daniel, e MCCLELLAN, Mark, Ownership form and trapped capital in the hospital industry, in E. GLAESER, The governance of not for profit organizations, Yale Law School, New Haven, maio 2002, research paper n. 266, disponível in www.ssrn.com. [05-08-2011].

KÜBLER, Friedrich, Gesellchaftsrecht, 1998, trad. esp. de Michèle Klein, Derecho de Sociedades, $5^{\mathrm{a}}$ ed., Madrid, Fundación Cultural del Notoriado, 2001.

LeOnARDo, Rodrigo Xavier, As Associações em Sentido Estrito no Direito Privado. Tese (doutorado) - Faculdade de Direito da USP, São Paulo, 2006. 
A Reforma do Direito das Associações sem Fins Econômicos pela Lei 11.127 de 2005 e o Terceiro Setor, in Revista de Direito do Terceiro Setor, ano 1, n. 1, jan./jul. 2007.

LOPES, Miguel Maria de Serpa, Curso de Direito Civil - Introdução, Parte Geral e Teoria dos Negócios Jurídicos, vol. I, $9^{\mathrm{a}}$ ed. rev. e atualizada por José Serpa de Santa Maria, Rio de Janeiro, Freitas Bastos, 2000.

Lopez, Teresa Ancona, Princípio da Precaução e Evolução da Responsabilidade Civil, São Paulo, Quartier Latin do Brasil, 2010.

, Principais Linhas da Responsabilidade Civil no Direito Brasileiro Contemporâneo, in Revista da Faculdade de Direito da USP, v. 101, 2006.

LÜCKerATH-Rovers, Mijntje, QUADRACKers, Luc; DE Bos, Auke, Non executive directors in the profit and non profit sector: a different approach towards governance?, Management on line review, 2009, disponível in www.ssrn.com [05-08-2011].

Lotufo, Renan, Código Civil Comentado, vol. 1, São Paulo, Saraiva, 2003.

MARCHI, Eduardo C. Silveira, Guia de Metodologia Jurídica, $2^{\mathrm{a}}$ ed., São Paulo, Saraiva, 2009.

MonteIRo, Washington de Barros, e Pinto, Ana Cristina de Barros Monteiro França, Curso de Direito Civil - Parte Geral, 42a ed., São Paulo, Saraiva, 2009.

Moraes, Walter, Sociedade Civil Estrita, São Paulo, RT, 1987.

OliveIRA, Gustavo Justino de, Direito do Terceiro Setor, in Revista de Direito do Terceiro Setor, ano 1, n.1, jan./jul. 2007.

PAES, José Eduardo Sabo, Fundações, Associações e Entidades de Interesse Social, $7^{\mathrm{a}}$ ed., Rio de Janeiro, Forense, 2010.

PereIRA, Caio Mário da Silva, Instituições de Direito Civil, vol. I, 12a ed., Rio de Janeiro, Forense, 1991.

PINTo, Carlos Alberto da Mota, Teoria Geral do Direito Civil, Coimbra, Coimbra, 1992.

Pontes de Miranda, Francisco Cavalcanti, Tratado de Direito Privado, Tomo I Introdução - Pessoas Físicas e Jurídicas, 2a ed., Rio de Janeiro, Borsoi, 1954.

ReAle, Miguel, As Associações no Novo Código Civil, Informativo Incijur, n. 45, abr. 2003.

Rocha, Sílvio Luís Ferreira da, Terceiro Setor, Coleção de temas de direito administrativo 7, São Paulo, Malheiros, 2003 
Rodrigues, Silvio, Direito Civil - Parte Geral, 15ª ed., São Paulo, Saraiva, 1985.

Roncero, Capilla, La Persona Juridica, Funciones e Disfunciones, Madrid, Tecnos, 1984.

RoPPO, Vincenzo, Il contratto, Milano, Giuffrè, 2001.

Rosas, Roberto, Razoabilidade e Proporcionalidade no Código Civil (2002), in Arruda Alvim, Joaquim Portes de Cerqueira César e Roberto Rosas (coord.), Aspectos Controvertidos no Novo Código Civil - Escritos em Homenagem ao Ministro José Carlos Moreira Alves, São Paulo, RRT, 2003.

RuBINO, Domenico, Le associazioni non riconosciute, trad. esp. de Manuel Gitrama Y Gonzalez, Las associaciones no reconocidas, Madrid, Revista de Derecho Privado, 1952.

SANTORINI, Massimo, Invalidità delle delibere di associazioni, Padova, Cedam, 1992.

SCAFF, Fernando Campos, Aspectos Fundamentais da Empresa Agrária, São Paulo, Malheiros, 1997.

, Teoria Geral do Estabelecimento Agrário, São Paulo, RT, 2001.

SOldEVILA, Pilar, OlIVERAS, Ester. Management control in non-profit organizations: the case of the associations of economists in Spain, UPF Economics and Business working paper n. 583, 2002, disponível in www.ssrn.com [05.08.2011].

SzTAJn, Raquel, Associações e Sociedades, São Paulo, RDM, ano XLI, n. 128, out./dez. 2002.

Teoria Jurídica da Empresa, 2a ed., São Paulo, Atlas, 2010.

Talavera, Glauber Moreno, Das Associações, in Luiz Antônio Scavone Jr. et al.(coord.), Comentários ao Código Civil, 2ª ed., São Paulo, RT, 2009.

Tomasetti Jr., Alcides, Execução do Contrato Preliminar, Tese (doutorado) - Faculdade de Direito da USP, São Paulo, 1982.

TravaglinI, Claudio, Improving NPO's accountability in the enlarged EU: towards a common framework for financial reporting in European NPOs, Università di Bologna, 2008, disponível in www.ssrn.com. [05.08.2011].

TEYssiÉ, Bernard, Droit Civil - Les Personnes, 4ª ed., Paris, Litec, 1999.

VerçosA, Haroldo Malheiros Duclerc, Contratos Mercantis e a Teoria Geral dos Contratos, São Paulo, Quartier Latin, 2010. 